\title{
CONTRIBUIÇÃO AO ESTUDO SOBRE AS INFLUÊNCIAS RECÍPROCAS ENTRE A TRIBUTAÇÃO DA RENDA E O COMÉRCIO INTERNACIONAL
}

\footnotetext{
Tese de doutorado, sob a orientação do Prof. Titular Dr. Luís Eduardo Schoueri, na subárea de Direito Tributário, integrada ao Departamento de Direito Econômico e Financeiro da Faculdade de Direito da USP
}

Faculdade de Direito da Universidade de São Paulo São Paulo - 2011 



\title{
RESUMO
}

A presente tese analisará a interação entre as regras de tributação da renda e os acordos de comércio internacional no âmbito da OMC - especificamente o GATT, o Acordo TRIMS, o ASMC e o GATS. A análise demonstrará que estes acordos, em sua conformação atual, vedam as subvenções tributárias veiculadas por meio de normas de tributação da renda capazes de concretizar determinadas políticas protecionistas. Ademais, arguirá que a identificação destas normas pelo Órgão de Solução de Controvérsias da OMC segue os ditames da teoria tributária aplicável à identificação das subvenções tributárias e padece dos mesmos problemas desta teoria.

\begin{abstract}
This thesis will analyze the interaction between income tax measures and the WTO agreements - particularly the GATT, TRIMS, Subsidies and Countervailing Measures and GATS agreements. The analysis will show that these agreements prohibit income tax measures that can be viewed as tax expenditures aimed at implementing certain protectionist policies. We will argue that the Dispute Settlement Body's approach to such measures follows the traditional tax expenditures theory and is subject to its shortcomings.
\end{abstract}




\section{ÍNDICE}

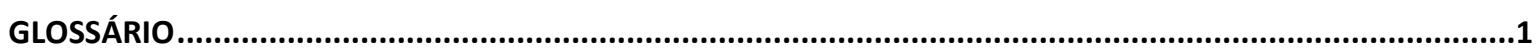

INTRODUÇÃO

I - SUBVENÇõES TRIBUTÁRIAS E TRIBUTAÇÃO DA RENDA ..............................................................10

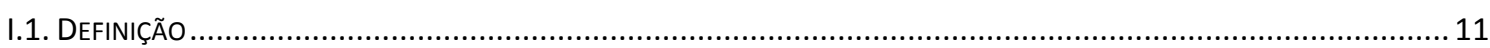

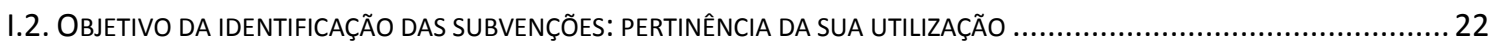

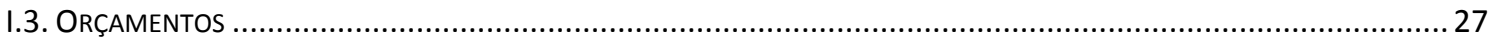

I.3.1. Primeiro passo para o orçamento: definição do parâmetro ............................................................. 29

I.3.2. Segundo passo para o orçamento: como calcular as subvenções? .............................................. 40

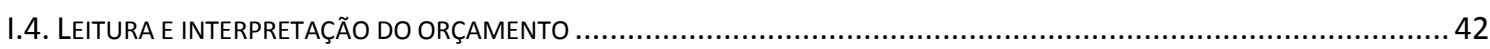

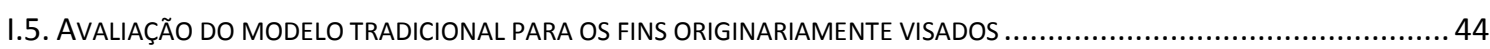

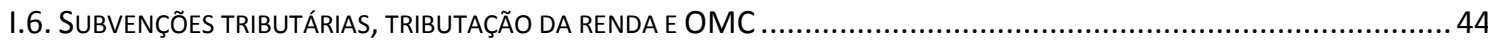

II - GATT E TRIMS

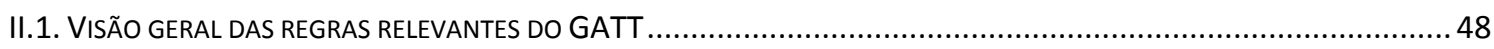

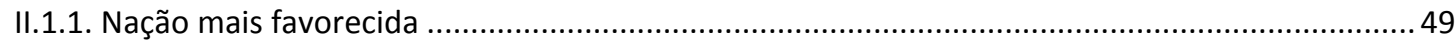

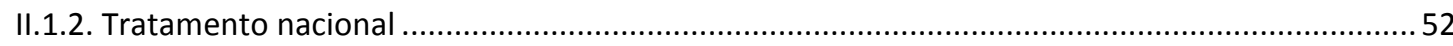

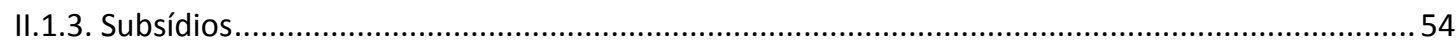

II.2. APLICAÇÃO DAS REGRAS DE NÃO DISCRIMINAÇÃO DO GATT À TRIBUTAÇÃO DA RENDA............................................56

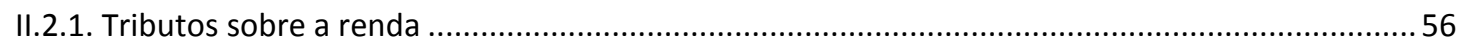

II.2.2. Dispositivos Relevantes dos Artigos I e III e as suas interpretações.................................................. 61

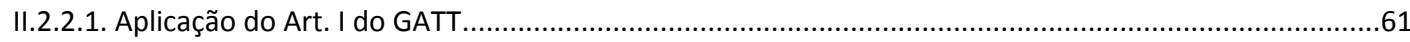

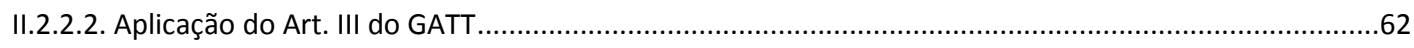

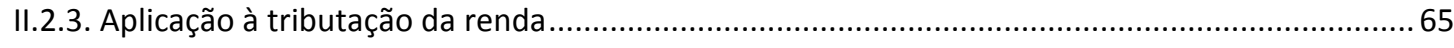

II.2.3.1. Tributos internos e outros encargos internos que incidem, direta ou indiretamente, sobre produtos.66

II.2.3.2. Leis, regulamentos e exigências relacionados com produtos ...........................................................71

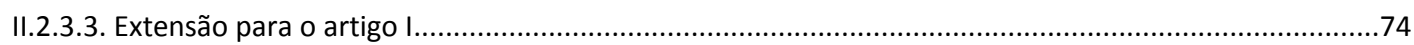

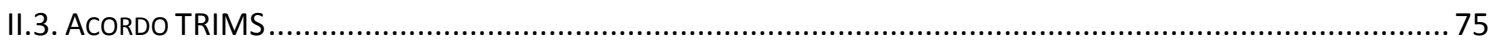

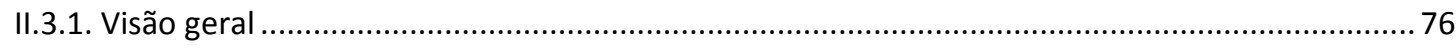

II.3.2. Aplicação à tributação da renda ......................................................................................... 80

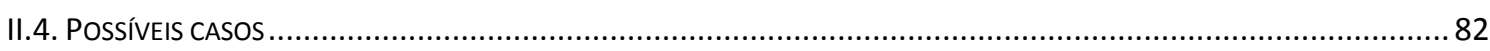

II.4.1. Regras de tributação da renda relacionadas a produtos .......................................................83

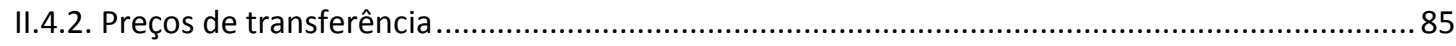

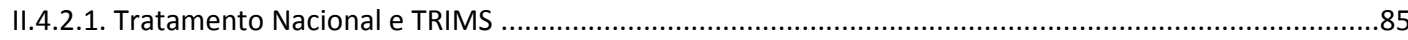

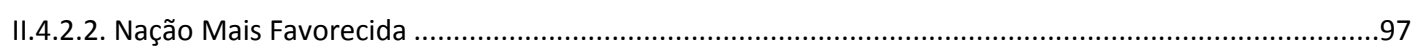

II.5. GATT, ACORDO TRIMS, TRIBUTAÇÃO DA RENDA E SUBVENÇÕES TRIBUTÁRIAS ..........................................103 


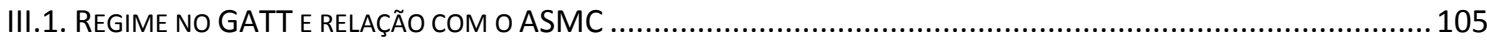

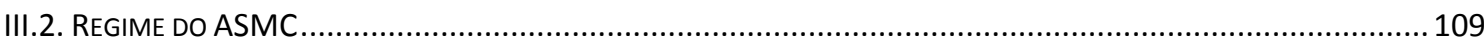

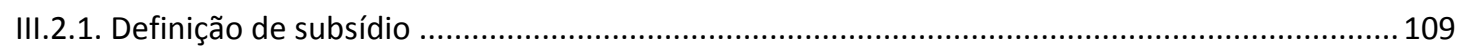

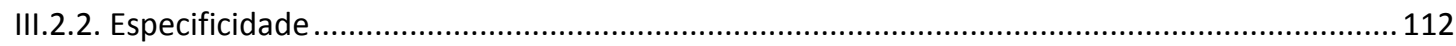

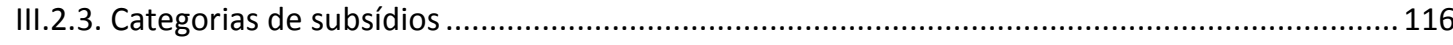

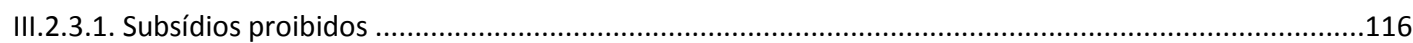

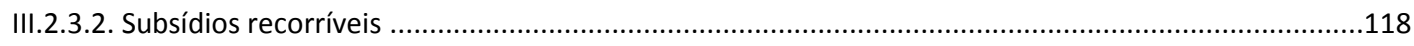

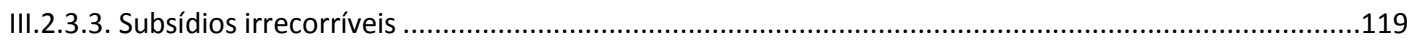

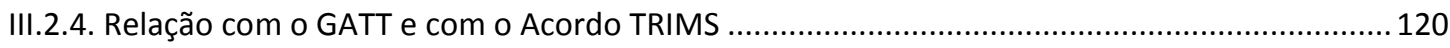

III.2.5. ASMC e o Acordo sobre Agricultura .............................................................................. 122

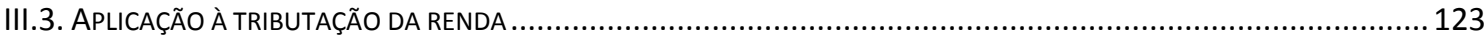

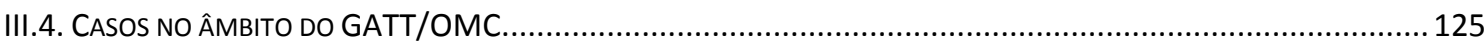

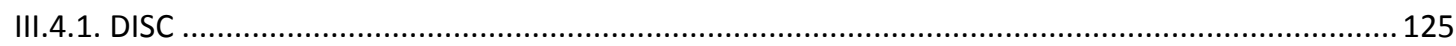

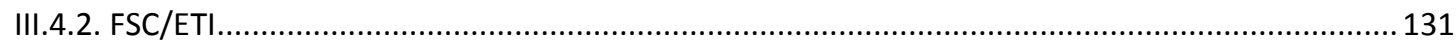

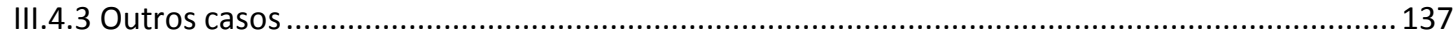

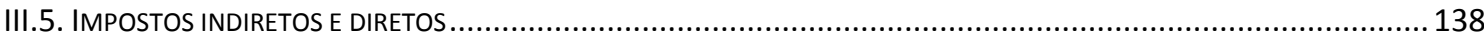

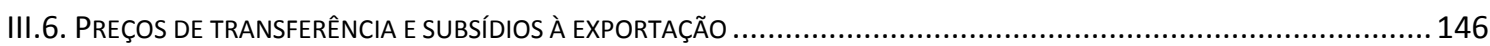

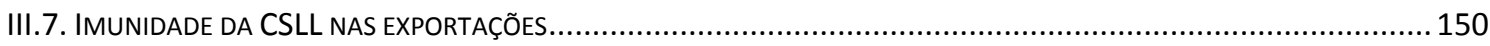

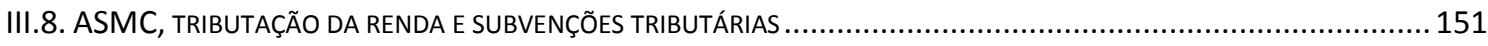

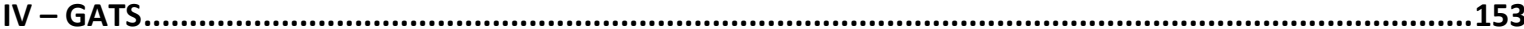

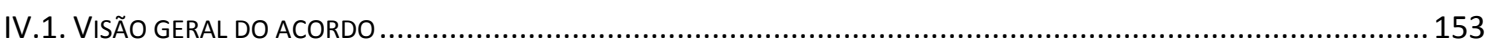

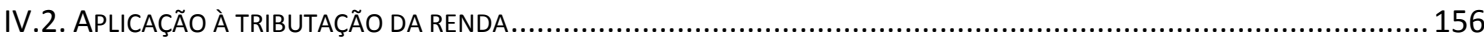

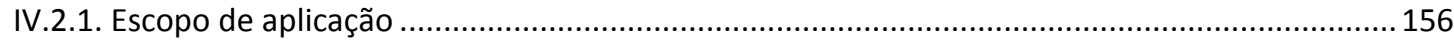

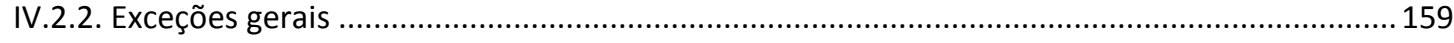

IV.2.2.1. Exceções de ordem pública e para evitar práticas dolosas ou fraudulentas.......................................161

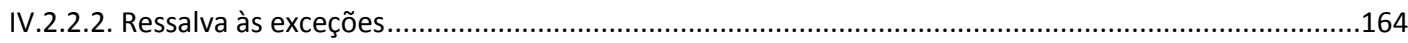

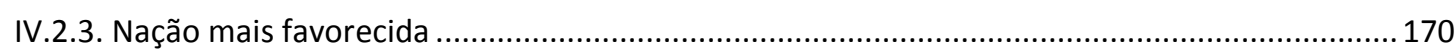

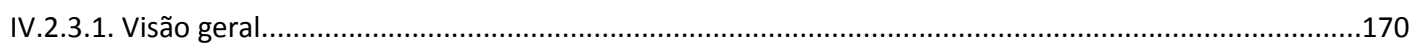

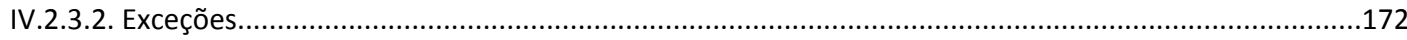

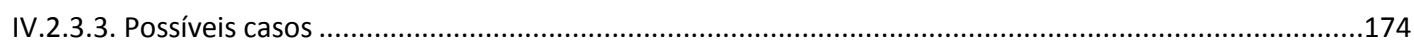

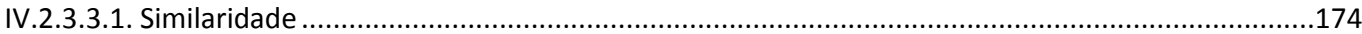

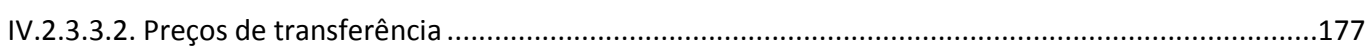

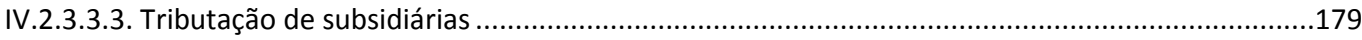

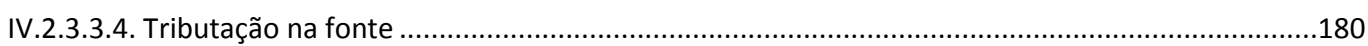

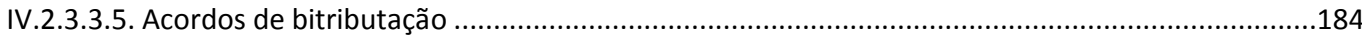

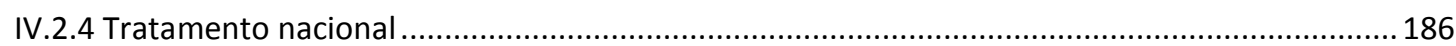

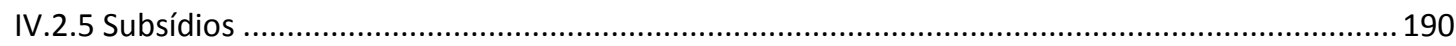




\section{GLOSSÁRIO}

Acordo TRIMS ${ }^{1}$ - Acordo Sobre Medidas de Investimento Relacionadas ao Comércio

ASMC - Acordo Sobre Subsídios e Medidas Compensatórias²

CFC - Empresas Controladas no Exterior (Controled Foreign Companies)

CSLL - Contribuição Social sobre o Lucro Líquido

CVDT - Convenção de Viena sobre o Direito dos Tratados ${ }^{3}$

DISC - Domestic International Sales Corporations

ETI - Extraterritorial Income Exclusion

EUA - Estados Unidos da América

FSC - Foreign Sales Corporations

GATS - Acordo Geral sobre o Comércio de Serviços ${ }^{4}$

GATT - Acordo Geral de Tarifas e Comércio ${ }^{5}$

IVA - Imposto sobre o Valor Agregado

TRIM - Medida de Investimento Relacionadas ao Comércio (Trade Related Investment Measure)

IED - Investimento Estrangeiro Direto

IRC - Internal Revenue Code (Código Tributário, que possui as regras do imposto de renda) dos Estados Unidos

IRPF - Imposto de Renda das Pessoas Físicas

IRPJ - Imposto de Renda das Pessoas Jurídicas

1 Nas referências ao Acordo TRIMS, a versão em português utilizada encontra-se em http://www.mdic.gov.br/arquivo/secex/omc/acordos/portugues/16trims.pdf [acesso em 01.02.2011].

2 Nas referências ao ASMC, a versão em português utilizada encontra-se em WwW.mdic.gov.br/arquivos/dwnl_1196686041.doc [acesso em 01.02.2011].

${ }^{3}$ Decreto $\mathrm{n}^{\mathrm{o}} 7.030$, de 14 de dezembro de 2009.

4 Nas referências ao GATS, a versão em português utilizada encontra-se em http://www.mdic.gov.br/arquivos/dwnl_1202730171.pdf [acesso em 01.02.2011].

${ }^{5}$ Nas referências ao GATT, a não ser que de outra forma indicado, referimo-nos ao texto em português do GATT 1947 com alterações posteriores, compilado em MERCADANTE, Aramita de Azevedo, Consolidação das normas do GATT 47, GATT 94 e OMC: legislação brasileira, São Paulo, Quartier Latin, 2007. 
OCDE - Organização para Cooperação e Desenvolvimento Econômico

OMC - Organização Mundial do Comércio

ONU - Organização das Nações Unidas

TCE - Tratado que institui a Comunidade Europeia (Tratado de Roma, de 25 de março de 1957, conforme a sua versão consolidada publicada no Jornal Oficial $n^{\circ}$ C 325 de 24 de Dezembro de 2002)

TJCE - Tribunal de Justiça das Comunidades Europeias

UE - União Europeia

OA - Órgão de Apelações da OMC

OSC - Órgão de Solução de Controvérsias da OMC 


\section{INTRODUÇÃO}

A OMC é, atualmente, a organização encarregada de supervisionar o comércio internacional, implementar os acordos negociados nas rodadas multilaterais, coordenar a negociação de novas regras e atuar como "tribunal" na decisão de conflitos do comércio internacional $^{6}$.

A organização baseia-se em princípios de comércio internacional desenvolvidos ao longo dos anos e consolidados em oito rodadas de negociação no âmbito do GATT $^{7}$.

Seu surgimento remonta ao final da Segunda Guerra Mundial e aos esforços para a criação de mecanismos estabilizadores para lidar com a crise econômica e a desorganização da economia mundial da época ${ }^{8}$.

Com o objetivo de juntar esforços para a reconstrução da economia mundial e criar um ambiente de maior cooperação na área da economia internacional, foi concluído em 1944 o acordo de Bretton Woods ${ }^{9}$, que tinha a proposta de criação de três instituições internacionais de funções distintas: o Fundo Monetário Internacional - FMI; o Banco Internacional para a Reconstrução e Desenvolvimento - BIRD (ou simplesmente Banco Mundial); e a Organização Internacional do Comércio - OIC.

Enquanto as duas primeiras instituições tornaram-se realidade, a última, principalmente em decorrência da não ratificação da Carta de Havana pelos Estados Unidos, acabou por não ser criada. Para resolver o impasse, vinte e três países aprovaram, em 1947, a parte da Carta de Havana que tratava das negociações quanto às tarifas e regras sobre o comércio - segmento este que se chamava General Agreement on Tariffs and Trade ${ }^{10}$.

\footnotetext{
${ }^{6}$ THORSTENSEN, Vera, OMC - Organização Mundial do Comércio: as regras do comercio internacional e a nova rodada de negociações multilaterais, $2^{\mathrm{a}}$ ed., São Paulo, Aduaneiras, 2001, p. 12.

${ }^{7}$ Idem, ibidem, p. 12.

${ }^{8}$ COSTA, José Augusto Fontoura, Decidir e julgar: um estudo multidisciplinar sobre a solução de controvérsias na Organização Mundial do Comércio, Tese de Titularidade apresentada na Faculdade de Direito da USP, São Paulo, 2009, p. 158.

${ }^{9}$ THORSTENSEN, Vera, op. cit., p. 29.

${ }^{10}$ Idem, ibidem, p. 30.
} 
Assim se originou o GATT, que, apesar de corporificar apenas parcela dos objetivos originalmente pretendidos pela OIC - i.e., aqueles referentes ao comércio de produtos - , forneceu a base institucional para as futuras rodadas de negociações sobre o comércio, as quais, décadas depois, resultariam na criação da OMC.

Até a Rodada de Tóquio $^{11}$, as negociações focaram-se em concessões recíprocas para a redução das barreiras tarifárias resultantes das políticas protecionistas então aplicadas. A partir da Rodada de Tóquio, negociada de 1973 a 1979, o foco das negociações passou a abranger barreiras não tarifárias ao livre comércio de bens, tais quais, subsídios, dumping, barreiras técnicas, compras governamentais e valoração aduaneira ${ }^{12}$.

A Rodada do Uruguai, da qual resultou o surgimento da OMC (que passou a funcionar a partir de 1995) representou maior evolução da regulamentação de medidas não tarifárias iniciada na Rodada de Tóquio e, paralelamente, integrou novos setores anteriormente excluídos - tais quais os serviços, determinadas medidas de investimentos e a propriedade intelectual - às discussões e regulamentação do comércio internacional ${ }^{13}$.

Para compreender como a tributação da renda enquadra-se neste cenário, é necessário que se atente, em primeiro lugar, ao efeito indutor da tributação ${ }^{14}$. É sabido que os tributos, além de arrecadarem receitas públicas para o Estado, influenciam os comportamentos dos agentes econômicos, pois incidem sobre tais comportamentos, atrelando-lhes um determinado preço ${ }^{15}$. Quanto maior o preço (tributário) para a realização de um determinado comportamento, menor será o número de agentes econômicos dispostos a realizá-lo, sendo a recíproca verdadeira. Assim, tributos induzem comportamentos, sendo que a realidade econômica com um tributo nunca será igual à realidade econômica constatada na sua ausência.

\footnotetext{
${ }^{11}$ Período que se estende desde a assinatura do acordo, em 1947, até o final da Rodada Kennedy, em 1967. A Rodada de Tóquio iniciou-se em 1973. O número de participantes cresceu de 23 para 62 neste período. Na Rodada de Tóquio já eram 102, e na do Uruguai 123. THORSTENSEN, Vera, OMC... cit (nota Erro! Indicador não definido.), p. 30.

${ }^{12}$ Idem, ibidem, p. 30 ..

${ }^{13}$ Idem, ibidem, p. 30 ..

14 SCHOUERI, Luis Eduardo, Normas tributárias indutoras e intervenção econômica, Rio de Janeiro, Forense, 2005, pp. 17 e 27.

${ }^{15}$ STGLITZ, Joseph E., Economics of the public sector, $3^{\mathrm{a}}$ ed., New York, Norton \& Company, 1999, p. 464465
} 
A tributação da renda não é uma exceção. Ela pode influenciar os mais diversos comportamentos dos indivíduos e ser utilizada como instrumento de política econômica para a consecução de uma série de objetivos, tais quais regular a relação entre poupança e consumo, incentivar investimentos em determinados ativos ou setores etc. Fazendo-se um corte no fenômeno da indução de comportamentos realizada pelo tributo sobre a renda, é possível apanhar aqueles casos que se mostram relevantes para as trocas internacionais internacional.

Constatado este efeito indutor, é necessário que distingamos, baseados nas lições de Reuven Avi-Yonah e Joel Slemrod ${ }^{16}$, duas formas diversas pelas quais normas de tributação da renda podem afetar a economia internacional ${ }^{17}$, quais sejam, o "protecionismo de fronteira" e o "protecionismo de propriedade".

$\mathrm{O}$ "protecionismo de fronteira" remete à circulação internacional de produtos e serviços. Neste caso, a política protecionista diferencia produtos e serviços nacionais dos importados, visa ao fechamento do mercado consumidor nacional aos produtos e serviços advindos do exterior. Ela opera, assim, "na fronteira", discriminando o "nacional" do "importado".

Ou seja, um produto advindo do exterior, ainda que seja produzido por uma subsidiária estrangeira de uma empresa detida por acionistas do próprio país importador, será tratado como um produto importado, sujeito ao "protecionismo de fronteira". O exemplo típico de medidas que concretizam este objetivo são as tarifas de importação, que gravam os produtos importados.

As barreiras não tarifárias também operam seguindo a mesma lógica do protecionismo de fronteira. Neste caso, apesar de não se tratar de uma tarifa, produtos

\footnotetext{
${ }^{16}$ AVI-YONAH, Reuvem S., SLEMROD, Joel, (How) should trade agreements deal with income tax issues?, disponível [on line] in www.law.umich.edu/centersandprograms/olin/papers.htm [=http://papers.ssrn.om/abstract=285345] [23.10.2005]; SLEMROD, Joel, Free Trade Taxation and Protectionist Taxation, NBER Working Paper Series, Working Paper $n^{\circ} 4902$, National Bureau of Economic Research, Cambridge, October 1994, disponível [on line] in www.nber.org/papers/w4902 [23.10.2005]; AVIYONAH, Reuvem S., The interaction of tax, trade and investment, in Ad Hoc group of experts on international cooperation in tax matters, eleventh meeting, United Nations (documento ST/SG/AC.8/2003/L.4), Geneva, 2003, disponível [on line] in www.un.org [23.10.2005].

${ }^{17}$ Por economia internacional entenda-se tanto as trocas internacionais de produtos e serviços, quanto a alocação internacional de fatores de produção, tais quais o capital e o próprio trabalho. Trata-se de fenômeno amplo que coincide com a própria alocação econômica internacional. NUSDEO, Fábio, Curso de economia: introdução ao direito econômico, $2^{\mathrm{a}}$ ed., São Paulo, RT, 2000, 324.
} 
importados serão discriminados dos produtos nacionais por outras medidas - subsídios ou TRIMS, por exemplo -, capazes de replicar os efeitos das tarifas.

Os acordos sob a OMC, em seu estado atual, prestam-se a lidar especificamente com este tipo de medidas, adotando a seguinte sistemática: (i) as políticas protecionistas devem se focar na adoção de tarifas, pois este é o meio mais transparente de implementá-las, sendo a redução de tais tarifas negociada sucessiva e multilateralmente entre os membros; (ii) outras medidas não tarifárias que realizam o protecionismo de fronteira deveriam ser eliminadas.

O "protecionismo de propriedade", por seu turno, não se refere a políticas que agem "na fronteira" sobre mercadorias ou serviços importados, mas a políticas que afetam a alocação do capital e da atividade produtiva multinacional.

As regras de tributação da renda tipicamente afetam esta alocação. Todas as regras que determinado país adotar em relação à tributação dos diversos tipos de fluxos transfronteiriços de rendimentos afetarão tanto a forma pela qual as empresas daquele país atuarão no mercado internacional, quanto a forma pela qual empresas de outros países atuarão em seu mercado. Opções fundamentais atinentes à estruturação do sistema de tributação da renda, tais quais a adoção da territorialidade ou universalidade, meios para eliminar a bitributação, momento da tributação dos lucros de controladas no exterior, tributação na fonte de não residentes, dentre outros, afetarão a inserção de determinado país no cenário global de alocação de capitais e atividade produtiva de empresas multinacionais.

Extensa literatura ${ }^{18}$ lida com questões concernentes a este tema e mostra que os Estados, inseridos no cenário econômico internacional, ao mesmo tempo competem e

18 Dentre outros, podemos citar: BARKER, William B., Optimal International Taxation and Tax Competition: Overcoming the Contradictions, in Northwestern Journal of International Law and Business, $\mathrm{v}$. 22, 2001-2002; BENSHALOM, Ilan, The New Poor at Our Gates: Global Justice Implications for International Trade and Tax Law, NYU Law Rev., v. 85, n. 1, 2010, disponível [on-line] in http://www.law.nyu.edu/ecm_dlv1/groups/public/@nyu_law_website_journals_law_review/documents/do cuments/ecm_pro_065472.pdf; BRAUNER, Yariv, An International Tax Regime in Crystallization: Realities, Experiences, and Opportunities, New York University School of Law Working Paper Series, Research Paper $\mathrm{n}^{\circ}$ 43, 2002, disponível [on-line] in www.ssrn.com/abratract id=315685 [30.07.09]; BRAUNER, Yariv, Integration in an Integrating World, disponível [on-line] in http://papers.ssrn.com/sol3/papers.cfm?abstract_id=670441 [30.07.09]; DECEREUX, Michael P., Business Taxation in a Globalized World, in Oxford Review of Economic Policy, v. 24, $\mathrm{n}^{\circ}$ 4, 2008, pp. 625-638; DESAI, Mihir A., HINES Jr., James R., Evaluating International Tax Reform, Haward NOM Research Paper 
cooperam na conformação de seus sistemas de tributação da renda a fim de concretizar objetivos de: (i) alcançar maior nível de neutralidade para os fluxos de fatores de produção; (ii) garantir um mercado nivelado que permita iguais oportunidades aos contribuintes dos Estados que dele participem, e também aos próprios Estados, no que tange ao seu desenvolvimento; e (iii) garantir, em vista da globalização da produção, as receitas tributárias dos Estados integrantes deste cenário internacional ${ }^{19}$.

Exemplo de cooperação é o notável esforço iniciado em 1921 com o Comitê Financeiro da Liga das Nações ${ }^{20}$ e posteriormente seguido pela OCDE e pela ONU para criar mecanismos para evitar a bitributação, pois desde aquela época notou-se que a bitributação constituía uma barreira aos investimentos internacionais ${ }^{21}$. As regras que atualmente lidam com a repartição de competências para a tributação de fluxos internacionais de rendimentos - constituídas por uma gama de mais de dois mil e quinhentos $^{22}$ acordos bilaterais para evitar a bitributação (que seguem em sua grande

$\mathrm{n}^{\circ}$ 03-48, 2003, disponível [on line] in http://ssrn.com/abstract=425943 [30.07.09]; DESAI, Mihir A., HINES Jr., James R., Old Rules and New Realities: Corporate Tax Policy in a Global Setting, Ross School of Business Working Paper ${ }^{\circ}$ 920, 2004, disponível [on-line] in www.ssrn.com/abstract=606222 [30.07.09]; DESAI, Mihir A., Securing Jobs or the New Protectionism?:Taxing the Overseas Activities of Mutionational Firms, disponível [on line ] in http://www.hbs.edu/research/pdf/09-107.pdf e http://papers.ssrn.com/sol3/papers.cfm?abstract id=1365907 [28.10.10]; DILWORTH, H. Robert, International Tax Reform and Some Proposals to Consider, paper apresentado no Senate Finance Committee, "The Foundation of International Tax Reform: Worldwide, Territorial, and Something in Between", 2008; DILWORTH, Robert H., Tax Reform: International Tax Issues and Some Proposals, in International Tax Journal, v. 35, $\mathrm{n}^{\circ}$ 1, 2009; GUTTENTAG, Joseph H., Key issues and options in international taxation: taxation in an interdependent world, in BIFD, v. 55, 2001, $\mathrm{n}^{\circ}$ 11, pp. 546-556; HINES JR., James R., Corporate taxation and international competition, Michigan, 2005, diponível [on line] in http://www.bus.umich.edu/otpr/wp2005-9.pdf [28.07.06]; HINES Jr., James R., SUMMERS, Lawrence H., How Globalization Affects Tax Design, Working Paper 14664, Cambridge, 2009, disponível [on line] in www.nber.org/papers/w14664 [30.07.09]; McLURE Jr., Charles E., International Aspects of Tax Policy for the $21^{\text {st }}$ Century, American Journal of Tax Policy, v. 167, 1989-1990.

${ }^{19}$ BRAUNER, Yariv, International trade and tax agreements may be coordinated, but not reconciled, in Virginia Tax Review (2005), pp. 282-311.

${ }^{20}$ Em 1921 o Comitê Financeiro da Liga das Nações encarregou quatro especialistas em finanças públicas Bruins (Holanda), Einaudi (Itália), Seligman (EUA) e Stamp (Reino Unido) - de efetuarem um relatório sobre os problemas relativos ao fenômeno da bitributação, bem como as possíveis soluções para a sua eliminação. O relatório foi editado em 1923. League of Nations Economic and Financial Commission, Report on Double Taxation: Document E.F.S.73.F.19, de 5 de abril de 1923. SCHOUERI, Luis Eduardo, Princípios no Direito Tributário Internacional: Territorialidade, Fonte e Universalidade, in Roberto Ferraz (org.), Princípios e limites da tributação, São Paulo, Quartier Latin, 2005, p. 357.

${ }^{21}$ Roberto França de Vasconcellos aponta que, ao contrário do que sugere o senso comum, a ideia de elaborar regras de repartição das competências tributárias dos países surge como medida de incentivo ao investimento internacional (decorrente, em um primeiro momento, de constatação da Liga das Nações, após a Primeira Guerra, que o fenômeno da bitributação poderia surtir efeitos negativos sobre tais investimento). VASCONCELLOS, Roberto França de, Aspectos econômicos dos tratados internacionais em matéria tributária, in RDTI, 1, pp. 147, 148, 154, 155 e 191

${ }^{22}$ AVI-YONAH, Reuven S., Double Tax Treaties: an Introduction, in Karl P. Sauvant, Lisa E. Sachs (orgs.), The Effects of Treaties on Foreign Direct Investment: Bilateral Investment Treaties, Double Taxation Treaties and Investment Flows, Oxford, Oxford University Press, 2009. 
maioria três modelos básicos ${ }^{23}$ ), bem como por dispositivos constantes dos direitos internos dos países inseridos no mercado internacional - decorrem em grande parte de tais esforços.

Exemplo de competição é a isenção para a tributação na fonte de rendimentos de juros de portfólio pagos a não-residentes. Os Estados Unidos, em 1984, em uma manobra de Ronald Reagan para angariar investimentos de portfólio estrangeiros, isentaram de tributação na fonte os juros pagos a não-residentes ${ }^{24}$. Como diversos investidores tinham a capacidade de evitar a tributação destes juros também no seu país de residência (por diferimento ou até mesmo evasão através de paraísos fiscais), a isenção da tributação na fonte implicou efetiva redução na tributação final destes juros, aumentando a taxa de retorno pós-tributo dos títulos americanos. Para permanecerem competitivos na atração de capitais em investimentos de portfólio, sem sofrer um aumento galopante de suas taxas de juros, os demais países tiveram de seguir o exemplo dos Estados Unidos e também isentar de tributação na fonte os juros pagos a investidores de portfólio estrangeiros.

Traçada esta linha divisória, acreditou-se por algum tempo que regras de tributação da renda não afetariam os objetivos de liberalização do comércio internacional visados pelo GATT e posteriormente pela OMC e que, por outro lado, as regras dos acordos no âmbito da OMC não se aplicariam a medidas de tributação sobre a renda ${ }^{25}$.

Todavia, ao contrário do que se acreditava, os casos DISC e FSC/ETI ${ }^{26}$, que serão examinados em detalhes adiante, mostraram que o GATT e outros acordos no âmbito da OMC podem abranger determinadas medidas de tributação da renda.

Paul $\mathrm{McDaniel}^{27}$ sugere que a tributação da renda somente interfere no comércio internacional regulado pela OMC em casos específicos em que os Estados editam normas tributárias que veiculam subvenções para a concreção de determinados programas

\footnotetext{
${ }^{23}$ Modelos da OCDE, ONU e Estados Unidos, os quais em muito se assemelham.

${ }^{24}$ AVI-YONAH, Reuven S., International Tax as International Law: an analysis of the international tax regime, New York, Cambridge University Press, 2007, p. 70.

${ }^{25}$ Ver Capítulo II infra.

${ }^{26}$ Ver Capítulos II e III infra.

${ }^{27}$ MCDANIEL, Paul, The impact of trade agreements on tax systems, in INTERTAX, v. 30, issue 5, 2002, pp. 166-171 e Trade agreements and income taxation: interactions, conflicts, and resolutions, Boston, 2004, disponível [on line] in http://www.un.org/esa/ffd/aconf198-11.pdf [05.11.2005].
} 
de políticas públicas. Conforme veremos, esta também parece ter sido a linha de raciocínio seguida pelo Painel e pelo Órgão de Apelação na decisão do caso FSC/ETI.

Tais normas seriam um desvio das regras "normais" de tributação da renda, e, por isso, poderiam realizar o chamado "protecionismo de fronteira", constituindo efetivas barreiras não tarifárias. Nestes casos, a tributação da renda afetaria o comércio internacional de modo contrário aos acordos no âmbito da OMC.

Considerando-se tal contexto, o objetivo deste trabalho é verificar se a referida hipótese - i.e., a de a tributação da renda e acordos sob a OMC somente se relacionarem em relação às subvenções tributárias - é verdadeira e quais as consequências concretas de sua aplicação.

Para tanto, o trabalho iniciará com a análise, no Capítulo I, do conceito de subvenção tributária do modo pelo qual foi construído pelas doutrinas de direito tributário e finanças públicas. Verificaremos, assim, quais os passos necessários para a identificação de uma subvenção veiculada por regras de tributação da renda, bem como as consequências de tal identificação. O final do Capítulo I proverá maiores detalhes acerca da aplicação da teoria das subvenções tributárias à análise de regras de tributação da renda à luz dos acordos no âmbito da OMC.

Nos capítulos seguintes, analisaremos os acordos no âmbito da OMC que possuem dispositivos relevantes para a tributação da renda - quais sejam, o GATT, o Acordo TRIMS, o ASMC e o GATS - de modo a verificar: (i) se há efetivos fundamentos jurídicos para aplicação de tais acordos a medidas de tributação da renda dos Estados Membros; (ii) qual a extensão de tal aplicação; (iii) que tipo de medidas concretas são abrangidas; e (iv) se a teoria das subvenções tributárias soluciona o problema da interação entre a tributação da renda e estes acordos.

Nesses termos, o Capítulo II lidará com a aplicação do GATT e do Acordo TRIMS, o Capítulo III com o ASMC e o Capítulo IV com o GATS. 


\section{I - SubVEnÇÕeS Tributárias E TRIBUTAÇÃO DA RENDA}

Comum é a metáfora do copo pela metade para demonstrar as diferenças entre o ponto de vista e o estado de espírito das pessoas. Um mesmo copo, com a metade do seu conteúdo preenchida com bebida, para alguns - os otimistas - estará "meio cheio"; para outros - os pessimistas -, "meio vazio".

O que determina a mudança do ponto de vista é o parâmetro tomado pelo indivíduo que analisa a situação. Assim, o otimista toma como parâmetro o copo vazio e, portanto, ao ver a metade do seu conteúdo preenchida com bebida, logo conclui: "está meio cheio" - denotando, implicitamente, que a situação é boa, pois, pelo seu parâmetro, a realidade poderia ser pior. Já o pessimista elege o copo cheio como parâmetro e, ao checar o conteúdo que tem em mãos, percebe que o copo em questão está meio vazio - denotando, implicitamente, que a situação é ruim, pois, de acordo com o seu parâmetro, a realidade poderia ser melhor.

O parâmetro, assim, é algo extrínseco à realidade apresentada; é algo que se toma para utilizar como índice de comparação da realidade. Destarte, a definição e a avaliação de uma situação dependem muito do parâmetro que se toma.

O problema da definição de um parâmetro de comparação para lidar com algumas questões na seara tributária e das finanças públicas não é novo. Esta necessidade fazia-se presente em teoria originada nos Estados Unidos da América, a qual apontava que algumas normas tributárias veiculavam políticas de gastos e, por isso, deveriam ser avaliadas como subvenções. A fim de saber o que (e quanto) se subvencionava, era necessário definir um parâmetro, a partir do qual se calcularia o desvio gerado pela norma tributária em questão. No desvio encontrar-se-ia a subvenção, sendo possível quantificá-la, incluí-la no orçamento e avaliar a sua pertinência.

Trata-se da teoria das tax expenditures ${ }^{28}$ que busca concretizar o louvável esforço de controlar as políticas de gastos realizadas por meio do sistema tributário. A

\footnotetext{
${ }^{28}$ Não há tradução perfeita para o termo. Poderíamos adotar, por exemplo, as seguintes traduções: gastos fiscais, subvenções fiscais, incentivos fiscais, benefícios fiscais, dentre outras. O Demonstrativo dos Gastos
} 
questão fundamental no contexto desta teoria era: o copo está "meio cheio", ou "meio vazio"? Em outras palavras, qual é o parâmetro que deve ser utilizado para a análise da norma tributária e constatação de uma subvenção?

Este problema foi o principal motivo das fortes críticas $^{29}$ à teoria das tax expenditures que apontavam que tal teoria dependeria de alguém ditar qual a estrutura tributária "correta", impondo o seu parâmetro sobre os demais e impedindo que, uma vez que se acredite que o copo está “meio vazio", outros o vejam como "meio cheio".

O problema, conforme veremos, repete-se no âmbito da OMC. Não obstante, os acordos atualmente em vigor pedem que este modelo seja adotado e que, em última análise, o Órgão de Solução de Controvérsias decida se ele está, ou não, em determinados casos, diante de uma subvenção.

\section{I.1. Definição}

A teoria das tax expenditures surgiu nos Estados Unidos, na década de 1960, em decorrência do trabalho de Surrey $^{30}$, à época secretário assistente do tesouro norte-

Governamentais Indiretos de Natureza Tributária de 2011, elaborado pela Receita Federal do Brasil (Demonstrativo dos Gastos Governamentais Indiretos de Natureza Tributária - 2011 (Gastos Tributários), 2011, disponível

[on line]

http://www.receita.fazenda.gov.br/publico/EstudoTributario/BensTributarios/2011/DGT2011.pdf

[25.01.2011]), utiliza a expressão "gastos tributários", substituindo o conceito de "benefícios tributários" utilizado anteriormente. O nosso objetivo é discutir a teoria original das tax expenditures e os seus desdobramentos. Sendo assim, ao longo do trabalho adotaremos os termos "subvenção tributária" e "gastos tributários" para fins de tradução, ou simplesmente utilizaremos o termo tax expenditure em inglês. Salientese, ainda, que, mesmo em inglês, a expressão tax expenditures é criticada, como se pode notar em BITTKER, Boris I., Accounting for federal "tax subsidies" in the national budget, in 22 Nat'l Tax J. 244 (1969) (reproduzido em CARON, Paul L., BURKE, Karen C. e McCOUCH, Grayson M.P. Federal Income Tax Anthology. Cincinnati, Ohio: Anderson1997. $2^{\mathrm{a}}$ tiragem) 2003, pp.303-306, que ressalta que a expressão, apesar de paradoxal (assim como a expressão "negative income tax"), deixa o seu sentido relativamente claro. O autor utiliza tax subsidy como sinônimo.

${ }^{29}$ KAHN, Douglas A, LEHMAN, Jeffrey S., Tax expenditure budgets: a critical view, in 54 Tax Notes 1661 (1992) (reproduzido em CARON, Paul L., BURKE, Karen C. e McCOUCH, Grayson M.P. Federal Income Tax Anthology. Cincinnati, Ohio: Anderson1997. 2a tiragem) 2003., pp. 310-312., pp. 310-312., criticam a teoria com base na impossibilidade de conformação da estrutura parâmetro.

30 SURREY, Stanley S., Federal income tax reform: the varied approaches necessary to replace tax expenditures with direct governmental assistance, in 84 Harvard Law Rev., 252 (1970) (reproduzido em CARON, Paul L., BURKE, Karen C. e McCOUCH, Grayson M.P. Federal Income Tax Anthology. Cincinnati, Ohio: Anderson1997. $2^{\mathrm{a}}$ tiragem) 2003. INFANTI, Anthony C., A tax crit identity crisis? Or tax expenditure analysis, deconstruction, and the rethinking of a collective identity, in Whittier Law Review, Vol. 26, (2005), p. 8. THURONYI, Victor, Tax expenditures: a reassessment, in 1988 Duke L. J. 1155, (reproduzido em CARON, Paul L., BURKE, Karen C. e McCOUCH, Grayson M.P. Federal Income Tax 
americano, no âmbito das discussões sobre a reforma do sistema de tributação da renda americano.

Em discurso de 15 de novembro de 1967, Surrey apontou que "por meio de desvios deliberados dos conceitos de renda líquida geralmente aceitos e por meio de várias isenções, deduções e créditos especiais, o nosso sistema tributário afeta a economia privada de uma maneira geralmente realizada por gastos públicos - de modo a produzir um sistema de gastos descrito em linguagem tributária"31. Ao trabalho de Surrey, adicionou-se a contribuição de Paul R. McDaniel ${ }^{32}$. A relevância do assunto foi destacada, ainda, na conferência da IFA de $1976^{33}$.

A partir de 1969, a contabilização das subvenções tributárias passou a ser adotada por uma série de países desenvolvidos membros da $\mathrm{OCDE}^{34}$ e por alguns países em desenvolvimento, tais quais o Paquistão e a Letônia ${ }^{35}$ e, após 1988, o Brasil, conforme veremos adiante.

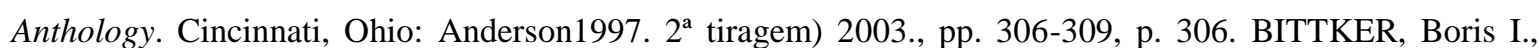
Accounting for federal "tax subsidies" in the national budget, in 22 Nat'l Tax J. 244 (1969) (reproduzido em CARON, Paul L., BURKE, Karen C. e McCOUCH, Grayson M.P. Federal Income Tax Anthology. Cincinnati, Ohio: Anderson1997. $2^{\text {a }}$ tiragem) 2003, p.303.

${ }^{31}$ Tradução livre do autor. No original: "through deliberate departures from accepted concepts of net income and through various special exemptions, deductions, and credits, our tax system does operate to affect the private economy in ways that are usually accomplished by expenditures - in effect to produce an expenditure system described in tax language. SURREY Stanley S., The U.S. income tax system - The need for a full accounting, speech before the Money Marketers, November 15, 1967. Exerpted in U.S. Treasury Department, 1969, Annual Report of the Secretary of the Treasury on the State of the Finances for Fiscal Year 1968, Washington, D.C., Government Printing Office, pp. 322-326, apud, SUNLEY, Emil, Tax expenditures in the United States: experience and practice, in SWIFT, Zhicheng Li, BRIXI, Hana Polackova, VALENDUC, Christian (orgs.), Tax expenditures - shedding light on government spending through the tax system, Washington DC, The World Bank, 2004, p. 155.

${ }^{32}$ SURREY, Stanley S., McDANIEL, Paul R., The tax expenditure concept: current developments and emerging issues, in 20 B. C. L. Rev. (1979), (reproduzido em CARON, Paul L., BURKE, Karen C. e McCOUCH, Grayson M.P. Federal Income Tax Anthology. Cincinnati, Ohio: Anderson1997. $2^{\mathrm{a}}$ tiragem) 2003, pp. 299-302.

${ }^{33}$ ENDE, Leo van den, HABERHAM, Amir, BOOGERT, Kees den, Tax expenditures in the Netherlands, in SWIFT, Zhicheng Li, BRIXI, Hana Polackova, VALENDUC, Christian (orgs.), Tax expenditures - shedding light on government spending through the tax system, Washington DC, The World Bank, 2004, p. 131.

${ }^{34}$ Em 1996 o Comitê de Assuntos Fiscais da OCDE investigou os sistemas de tax expenditures de quatorze Estados Membros, analisando as diferenças de cada um deles, bem como as razões para estas diferenças. SHI, Yaobin, Establishing a tax expenditure administrative system that achieves a sound fiscal system in China, in SWIFT, Zhicheng Li, BRIXI, Hana Polackova, VALENDUC, Christian (orgs.), Tax expenditures shedding light on government spending through the tax system, Washington DC, The World Bank, 2004, p. 182.

${ }^{35}$ SUNLEY, Emil, op. cit., p. 155. 
Conforme se verifica do próprio discurso de Surrey, subvenções tributárias são um tipo de instrumento do qual o governo pode se valer para implementar políticas específicas $^{36}$.

Nesse sentido, Swift, Brixi e Valenduc ${ }^{37}$ identificam três instrumentos utilizados como meios para financiar políticas governamentais. O primeiro deles é o gasto direto, que goza de maior transparência do que qualquer um dos outros, pois, submetido à aprovação orçamentária, (teoricamente) sempre se sujeitaria a questionamentos quanto ao seu custo-benefício ${ }^{38}$, bem como às eficiências alocativa e operacional. O segundo instrumento, menos transparente do que os gastos diretos, seria aquele que os autores chamam de passivos contingentes ${ }^{39}$, que são passivos governamentais gerados por eventos futuros e incertos. Como exemplo, podem ser citados programas de seguros governamentais e de auxílio a empresas públicas. O terceiro instrumento consubstancia-se nas já aludidas subvenções tributárias.

Schoueri $^{40}$ e Bakija e Slemrod ${ }^{41}$ esclarecem que políticas de gastos públicos podem ser implementadas por ao menos duas maneiras diversas, quais sejam: (i) programas de gastos diretos; e (ii) incentivos fiscais. A primeira situação, em que todos os contribuintes são tributados à mesma alíquota e uma categoria destes contribuintes é subsidiada por um programa de gastos diretos seria semelhante, em seus efeitos, à segunda

${ }^{36}$ VALENDUC, Cristian, From tax expenditure reporting to tax policy analysis: some experience from Belgium, in SWIFT, Zhicheng Li, BRIXI, Hana Polackova, VALENDUC, Christian (orgs.), Tax expenditures - shedding light on government spending through the tax system, Washington DC, The World Bank, 2004, p. 69.

37 SWIFT, Zhicheng Li, BRIXI, Hana Polackova, VALENDUC, Christian, Tax expenditures: general concept, measurement, and overview of country practices, in SWIFT, Zhicheng Li, BRIXI, Hana Polackova, VALENDUC, Christian (orgs.), Tax expenditures - shedding light on government spending through the tax system, Washington DC, The World Bank, 2004, p. 2.

${ }^{38}$ Sobre a análise custo benefício dos gastos públicos, cf. OLIVEIRA, R. G. de, Análise de custo-benefício, in ARVATE, Paulo, BIDERMAN, Ciro (eds.), Economia do setor público no Brasil, Rio de Janeiro, Elsevier, 2004, pp. 321-338. A análise também seria aplicável às subvenções tributárias. Contudo, como a mensuração e exposição destas subvenções à crítica orçamentária é menor do que dos gastos diretos, a análise fica prejudicada. SHI, Yaobin, Establishing a tax expenditure administrative system that achieves a sound fiscal system in China, in SWIFT, Zhicheng Li, BRIXI, Hana Polackova, VALENDUC, Christian (orgs.), Tax expenditures - shedding light on government spending through the tax system, Washington DC, The World Bank, 2004, p. 185, sugere alguns métodos de análise custo-benefício das subvenções tributárias, quais sejam: (i) valor presente líquido dos benefícios; (ii) razão dos benefícios em relação aos custos; e (iii) taxa de retorno interna.

${ }^{39}$ Contingent liabilities.

40 SCHOUERI, Luís Eduardo, Normas tributárias indutoras e intervenção econômica, Rio de Janeiro, Forense, 2005, pp. 57 e ss.

${ }^{41}$ BAKIJA, Jon, SLEMROD, Joel, Taxing ourselves: a citizen's guide to the debate over taxes, $3^{\mathrm{a}}$ ed., MIT Press, Cambridge, 2004, pp. 166-168. 
situação, em que a categoria subsidiada na situação anterior recebe uma isenção tributária, enquanto o restante dos contribuintes paga os seus tributos normalmente ${ }^{42}$.

Pois bem, se normas tributárias podem ser utilizadas como instrumentos para realizar programas de gastos públicos - i.e., subvenções -, é necessário que se construa um arcabouço teórico apto a analisá-las como tais. Desta necessidade surgiu a teoria das tax expenditures.

Nesses termos, entende-se que tax expenditures são concessões desenhadas para prover um benefício a uma atividade específica ou a um grupo de contribuintes, podendo assumir diversas formas, como isenções, deduções, reduções de alíquota e diferimentos ${ }^{43}$.

Parte-se da premissa que o principal objetivo do sistema tributário deveria ser arrecadar receitas para financiar gastos públicos da maneira mais eficiente, bem como garantir uma distribuição justa da carga tributária ${ }^{44}$. Contudo, visando a objetivo diverso, os governos frequentemente utilizam os sistemas tributários para promover políticas específicas, prática esta que resulta nas tax expenditures ${ }^{45}$.

O ato do Congresso americano de 1974, que obrigou a Administração e o Congresso a prepararem listas anuais de tax expenditures, as definiu como "perdas de receita atribuíveis a dispositivos das leis tributárias federais que permitem uma exclusão especial, isenção, ou dedução da renda bruta ou que estabeleçam um crédito especial, uma alíquota especial, ou o diferimento do ônus tributário" ${ }^{46}$. Esta definição sugere que as

42 BROWN, Colin, Tax expenditures in Australia, in SWIFT, Zhicheng Li, BRIXI, Hana Polackova, VALENDUC, Christian (orgs.), Tax expenditures - shedding light on government spending through the tax system, Washington DC, The World Bank, 2004, p. 46, salienta que os benefícios da maioria das subvenções tributárias poderiam ser igualmente providos por meio de gastos diretos. Assim, tais subvenções consubstanciar-se-iam em um mecanismo alternativo aos gastos diretos para a realização de políticas governamentais, tendo efeito orçamentário similar àquele causado pelos gastos.

${ }^{43}$ Idem, ibidem, p. 45.

${ }^{44}$ VALENDUC, Cristian, From tax expenditure reporting to tax policy analysis: some experience from Belgium, in SWIFT, Zhicheng Li, BRIXI, Hana Polackova, VALENDUC, Christian (orgs.), Tax expenditures - shedding light on government spending through the tax system, Washington DC, The World Bank, 2004, p. 69.

45 SWIFT, Zhicheng Li, BRIXI, Hana Polackova, VALENDUC, Christian, Tax expenditures: general concept, measurement, and overview of country practices, in SWIFT, Zhicheng Li, BRIXI, Hana Polackova, VALENDUC, Christian (orgs.), Tax expenditures - shedding light on government spending through the tax system, Washington DC, The World Bank, 2004, p. 2.

${ }^{46}$ Tradução livre do autor. No orginal: "revenue losses attributable to provisions of the federal tax laws which allow a special exclusion, exemption, or deduction from gross income or which provide a special credit, a preferential rate of tax, or a deferral of liability." 
tax expenditures são exceções a um suposto tributo normal. Este tributo normal, contudo, não é definido em qualquer lei, nem no próprio ato do Congresso mencionado acima ${ }^{47}$.

Todavia, o conceito de tax expenditures nos Estados Unidos sofreu importante reforma em 2009 com a edição e relatório sobre o assunto pelo Joint Committee on Taxation do Congresso ${ }^{48}$. A razão dada por este comitê para a revisão foi que o conceito usado anteriormente gerava infindáveis debates acerca do que se deveria considerar o sistema tributário parâmetro, ou "normal". Isto submetia o orçamento a extensas críticas, fragilizando e diminuindo a credibilidade e utilidade do orçamento.

Desta maneira, o relatório do Joint Committee propõe que as tax expenditures sejam classificadas em duas categorias, quais sejam: (i) tax subsidies, identificados em relação a regras gerais encontradas no próprio código do imposto de renda americano (o “Internal Revenue Code", ou simplesmente "IRC"), e não com referência a um sistema "normal" hipotético; e (ii) tax induced structural distortions, caracterizadas como elementos do Internal Revenue Code que, apesar de não poderem ser identificados como desvios de regras gerais do código (pois tais regras gerais, nestes casos, não podem ser encontradas), materialmente afetam decisões econômicas de uma maneira que impõe custos substanciais em termos de eficiência econômica do sistema tributário.

Com isso, pretendeu-se evitar a referência a qualquer parâmetro extrínseco ao próprio sistema tributário norte-americano e apenas classificar como subvenções as regras que claramente desviam de um parâmetro geral do código. Outras regras que não podem ser ignoradas, porque claramente afetam o comportamento dos contribuintes, implementando políticas públicas às custas de uma tributação mais neutra, são analisadas pelo orçamento, mas não são diretamente qualificadas como subvenções.

O grupo de estudos das tax expenditures holandesas, para o seu relatório de 1987, estudou as definições adotadas por outros países, especialmente a França, a Alemanha, o Reino Unido e os EUA, isolando cinco elementos distintos caracterizadores das tax expenditures, quais sejam: (i) redução na receita tributária; (ii) desvio de uma

\footnotetext{
${ }^{47}$ SUNLEY, Emil, Tax expenditures in the United States: experience and practice, in SWIFT, Zhicheng Li, BRIXI, Hana Polackova, VALENDUC, Christian (orgs.), Tax expenditures - shedding light on government spending through the tax system, Washington DC, The World Bank, 2004, p. 156.

${ }^{48}$ JOINT COMMETTEE OF TAXATION, A Reconsideration of Tax Expenditure Analysis (JCX-37-08), 2008, disponível [on-line] in http://www.jct.gov/x-37-08.pdf [30.07.09].
} 
estrutura tributária parâmetro; (iii) objetivo de política pública não arrecadatório; (iv) conversibilidade em gastos diretos; e (v) aplicação a um grupo limitado de contribuintes ${ }^{49}$. Todavia, os elementos (iii), (iv) e (v) referidos acima foram descartados pelo grupo na definição holandesa.

O elemento de redução na receita demonstra que a tax expenditure é, na verdade, uma subvenção oculta; já o elemento "desvio da estrutura tributária parâmetro" serve para comparar a tax expenditure com a situação mais neutra, ou seja, situação em que o Estado seria financiado de modo que a carga tributária necessária para tanto fosse igualmente distribuída de acordo (apenas) com a capacidade contributiva.

Desta feita, o grupo holandês, baseado nos elementos que considerou relevantes, formulou a sua definição de tax expenditure como um gasto governamental na forma de perda ou diferimento de receita que decorre de uma norma tributária que não está de acordo com a estrutura parâmetro da lei tributária.

No Brasil, o Poder Executivo ${ }^{50}$ é obrigado a elaborar demonstrativo anual de subvenções tributárias, que deve acompanhar o projeto de lei orçamentária anual. Tal exigência consta do parágrafo $6^{\circ}$ do artigo 165 da Constituição Federal ${ }^{51}$ (que estabelece a obrigação de o Poder Executivo apresentar demonstrativo regionalizado do efeito, sobre as receitas e despesas, decorrente de isenções, anistias, remissões, subsídios e benefícios de natureza tributária, financeira e creditícia) e do inciso II do artigo $5^{\circ}$ da Lei Complementar $\mathrm{n}^{\mathrm{o}}$ 101/00 ("Lei de Responsabilidade Fiscal”, que estabelece que o projeto de lei orçamentária anual será acompanhado de documento a que se refere o $\S 6^{\circ}$ do art. 165 da Constituição Federal, bem como das medidas de compensação de renúncias de receita e do aumento de despesas obrigatórias de caráter continuado).

\footnotetext{
${ }^{49}$ ENDE, Leo van den, HABERHAM, Amir, BOOGERT, Kees den, Tax expenditures in the Netherlands, in SWIFT, Zhicheng Li, BRIXI, Hana Polackova, VALENDUC, Christian (orgs.), Tax expenditures - shedding light on government spending through the tax system, Washington DC, The World Bank, 2004, p. 134.

${ }^{50}$ Conforme aponta HENRIQUES, Elcio Fiori, O gasto tributário no direito brasileiro, 2009, disponível [online]

http://www.tesouro.fazenda.gov.br/premio_TN/XIVPremio/financas/1tefpXIVPTN/monografia_Tema2_Elci o_Fiori_Henriques.pdf [28.01.2011], p. 3, a União é o único ente da federação que publicou regularmente, desde 1989, estes demonstrativos requeridos pela Constituição Federal de 1988.

${ }^{51}$ A exigência de elaboração destes demonstrativos surgiu no ordenamento brasileiro com a Constituição Federal de 1988. Idem, ibidem, p. 17.
} 
$\mathrm{O} \S 6^{\circ}$ do artigo 165 da Constituição Federal não define precisamente o que se deve considerar como "benefícios de natureza tributária".

Por seu turno, o $\S 1^{\circ}$ do artigo 14 da Lei Complementar $n^{\circ}$ 101/00 determina que a renúncia de receita gerada por um benefício de natureza tributária compreende "anistia, remissão, subsídio, crédito presumido, concessão de isenção em caráter não geral, alteração de alíquota ou modificação de base de cálculo que implique redução discriminada de tributos ou contribuições, e outros benefícios que correspondam a tratamento diferenciado".

A partir desta definição, constatamos que a Lei Complementar $n^{\circ} 101 / 00$, ao mesmo tempo em que estabelece expressamente que alguns institutos de direito tributário (e.g., a isenção, a anistia e a remissão de tributos) devem ser considerados benefícios de natureza tributária, deixa em aberto uma segunda categoria de "outros benefícios que correspondam a tratamento diferenciado".

Determinar se um benefício implica tratamento diferenciado, necessariamente depende da definição de um parâmetro normativo de comparação. A definição deste parâmetro ficará a cargo do órgão que elaborar o demonstrativo de subvenções tributárias exigido pela $\mathrm{LC}^{\circ}$ 101/00.

A Receita Federal ${ }^{52}$ elabora anualmente demonstrativos de gastos de natureza tributária da União. Na introdução ao Demonstrativo dos Gastos Governamentais Indiretos de Natureza Tributária de 2011 (doravante denominado simplesmente "Demonstrativo"), ela procura iluminar esta questão ao buscar conceituar os "gastos tributários", conforme reproduziremos a seguir.

O Demonstrativo aponta que, em geral, os sistemas tributários não possuem outro objetivo que não o de gerar recursos para a administração. O dispêndio de tais recursos é feito por meio de gastos previstos em orçamentos aprovados pelos representantes da população. No entanto, constata-se na realidade que o sistema tributário é permeado por desonerações.

52 RECEITA FEDERAL DO BRASIL, Demonstrativo dos Gastos Governamentais Indiretos de Natureza Tributária - 2011 (Gastos Tributários), Brasília, 2011, disponível [on line] in http://www.receita.fazenda.gov.br/publico/EstudoTributario/BensTributarios/2011/DGT2011.pdf [25.01.2011], pp. 6-11. 
Nesse sentido, são consideradas desonerações tributárias todas e quaisquer situações que promovam: presunções creditícias, isenções, anistias, reduções de alíquotas, deduções ou abatimentos e adiamentos de obrigações de natureza tributária. Tais desonerações podem servir para diversos fins, tais quais:

(i) simplificar e/ou diminuir os custos da administração;

(ii) promover a equidade;

(iii) corrigir desvios;

(iv) compensar gastos realizados pelos contribuintes com serviços não atendidos pelo governo;

(v) compensar ações complementares às funções típicas de estado desenvolvidas por entidades civis;

(vi) promover a equalização das rendas entre regiões; e/ou,

(vii) incentivar determinado setor da economia.

Conforme o Demonstrativo, nos casos dos itens (iv), (v), (vi) e (vii) as desonerações representam ações de políticas de governo (ações essas que têm como objetivo a promoção do desenvolvimento econômico ou social) não realizadas no orçamento e sim por intermédio do sistema tributário.

É este grupo de desonerações que o Demonstrativo denomina "gastos tributários", reconhecendo que não há um procedimento universalmente aceito e padronizado para a determinação de tais gastos. Todavia o Demonstrativo aponta para algumas similaridades observadas na sua identificação, quais sejam:

(i) as desonerações tributárias devem possuir objetivos similares aos das despesas públicas; possuem, portanto, uma lógica orçamentária associada; 
(ii) estas desonerações apresentam-se como um desvio da "estrutura normal da tributação" ${ }^{, 53}$; sendo sempre de caráter não geral.

Por fim, o Demonstrativo complementa que os dois passos para a identificação dos gastos tributários podem ser resumidos da seguinte forma:

(i) Determinar todas as desonerações tributárias tomando como base um sistema tributário de referência; e

(ii) Avaliar, utilizando um conjunto de critérios definidos, quais desonerações são gastos indiretos, passíveis de serem substituídas por gastos diretos.

Este método, que foi adotado a partir de 2004, representa, segundo o Demonstrativo, uma mudança em relação ao método anterior.

Com efeito, de 1988 até 2004, a Receita Federal elaborava o "Demonstrativo dos Benefícios Tributários - DBT" referente aos tributos federais por ela administrados.

O conceito de benefício tributário adotado anteriormente a 2004 não embutia a ótica orçamentária. Consequentemente, alguns benefícios tributários anteriormente relacionados pela Receita Federal não se enquadram na nova conceituação de gastos tributários e alguns gastos tributários atualmente considerados não estavam relacionados entre os benefícios tributários constantes dos demonstrativos anteriores.

Assim, buscando aprimorar o conceito utilizado e promovendo uma maior uniformização com o entendimento utilizado em outros países, a Receita Federal passou a utilizar o termo "gasto tributário" em substituição ao termo "benefício tributário", adotando, a partir do demonstrativo de 2004, o seguinte conceito:

(i) Gastos tributários são gastos indiretos do governo realizados por intermédio do sistema tributário, visando atender objetivos econômicos e sociais.

\footnotetext{
${ }^{53}$ Veremos, no tópico I.3.1 adiante, o que o Demonstrativo considera como "estrutura normal da tributação" e teceremos algumas críticas.
} 
(ii) São explicitados na norma que referencia o tributo, constituindo-se uma exceção ao sistema tributário de referência, reduzindo a arrecadação potencial e, consequentemente, aumentando a disponibilidade econômica do contribuinte.

(iii) Têm caráter compensatório, quando o governo não atende adequadamente a população dos serviços de sua responsabilidade, ou têm caráter incentivador, quando o governo tem a intenção de desenvolver determinado setor ou região.

(iv) Sua identificação deve ser feita seguindo dois passos:

a. Determinar se constituem desvios do sistema tributário de referência; e

b. Determinar se tais desvios seriam passíveis de conversão em gastos diretos.

A análise de todas as definições apresentadas mostra que o primeiro passo para a identificação e estimativa do valor de uma subvenção tributária é determinar qual a estrutura tributária que normalmente seria aplicável.

Este tratamento tributário que se aplicaria caso não existisse a subvenção tributária é o parâmetro (benchmark, ou sistema de referência) ${ }^{54}$. O parâmetro não deve favorecer ou desfavorecer atividades equivalentes ou classes de contribuintes. A partir de então, as subvenções tributárias são definidas como desvios deste parâmetro ${ }^{55}$.

Saliente-se, contudo, que nem toda concessão é necessariamente entendida como subvenção tributária. Algumas delas são vistas como parte integrante da estrutura tributária parâmetro. Assim, há um julgamento envolvido na identificação de quais

\footnotetext{
${ }^{54}$ INFANTI, Anthony C., A tax crit identity crisis? Or tax expenditure analysis, deconstruction, and the rethinking of a collective identity, in Whittier Law Review, Vol. 26, (2005), p. 8., aponta que a teoria das tax expenditures pede que as normas tributárias sejam divididas em dois grupos, quais sejam: (i) normas estruturais, ou parâmetro; e (ii) preferências fiscais/penalidades. Uma norma tributária que fuja do parâmetro provavelmente gerará uma diferença direcionada na carga fiscal, a qual pode ser vista como uma subvenção a um determinado grupo de contribuintes ou a determinada atividade econômica.

${ }^{55}$ BROWN, Colin, Tax expenditures in Australia, in SWIFT, Zhicheng Li, BRIXI, Hana Polackova, VALENDUC, Christian (orgs.), Tax expenditures - shedding light on government spending through the tax system, Washington DC, The World Bank, 2004, p. 46.
} 
elementos do sistema tributário são subvenções tributárias e quais integram a estrutura parâmetro.

Como já foi adiantado, é neste ponto que reside uma das principais dificuldades da análise das subvenções tributárias: não há qualquer regra para definir o que é parâmetro. Diferentes definições do parâmetro implicarão diferentes mensurações dos gastos públicos veiculados por meio de normas tributárias. Daí as críticas à teoria das tax expenditures $^{56}$, as quais apontam o seu subjetivismo (o copo está "meio cheio" ou "meio vazio"?).

Este fato, ademais, torna a comparação internacional difícil de ser realizada ${ }^{57}$. Seguin e Gurr ${ }^{58}$ apontam que, apesar de haver certo consenso no que tange à definição acerca do que são tax expenditures, não há qualquer metodologia amplamente aceita para apurá-las. Internacionalmente, nota-se que há uma gama delas, algumas mais amplas e outras restritivas. Swift, Brixi e Valenduc ${ }^{59}$, ao introduzirem estudo comparativo das políticas de tax expenditures de diferentes países, também apontam que não é possível realizar uma comparação internacional da magnitude daquelas, pois cada país utiliza diferentes sistemas parâmetro e, portanto, os dados não são comparáveis. Não há, assim, acordo acerca do sistema parâmetro, tampouco, consequentemente, sobre quais normas devem ser consideradas subvenções tributárias.

\footnotetext{
${ }^{56}$ THURONYI, Victor, Tax expenditures: a reassessment, in 1988 Duke L. J. 1155, (reproduzido em CARON, Paul L., BURKE, Karen C. e McCOUCH, Grayson M.P. Federal Income Tax Anthology. Cincinnati, Ohio: Anderson, 1997) 2003., pp. 306-309.

${ }^{57}$ BROWN, Colin, Tax expenditures in Australia, in SWIFT, Zhicheng Li, BRIXI, Hana Polackova, VALENDUC, Christian (orgs.), Tax expenditures - shedding light on government spending through the tax system, Washington DC, The World Bank, 2004, p. 46.

${ }^{58}$ SEGUIN, Marc, GURR, Simon, Federal tax expenditures in Canada, in SWIFT, Zhicheng Li, BRIXI, Hana Polackova, VALENDUC, Christian (orgs.), Tax expenditures - shedding light on government spending through the tax system, Washington DC, The World Bank, 2004, p. 97.

59 SWIFT, Zhicheng Li, BRIXI, Hana Polackova, VALENDUC, Christian, Tax expenditures: general concept, measurement, and overview of country practices, in SWIFT, Zhicheng Li, BRIXI, Hana Polackova, VALENDUC, Christian (orgs.), Tax expenditures - shedding light on government spending through the tax system, Washington DC, The World Bank, 2004, pp. 1-3.
} 


\section{I.2. Objetivo da identificação das subvenções: pertinência da sua utilização}

Surrey, após explicitar a existência das tax expenditures, é enfático ao apontar a necessidade de identificá-las no sistema tributário para se verificar se não seria mais adequado substituí-las por subvenções diretas ou, simplesmente, eliminá-las ${ }^{60}$.

Para o autor, na maioria das vezes, as subvenções tributárias de um dado ordenamento poderiam simplesmente ser eliminadas, seja por realizarem políticas que não se sustentam, ou por se provarem ineficientes para alcançar o objetivo visado. No restante dos casos, a substituição destas subvenções tributárias por políticas de subvenções diretas poderia ser mais adequada. Deste modo, a proposta de Surrey, ao tratar das tax expenditures, é ter um mapa hábil a identificá-las e controlá-las, a fim de, principalmente, orientar propostas de reforma tributária.

Nesses termos, com o objetivo de contextualizar o ambiente no qual nasceu a teoria das tax expenditures, é relevante que se façam algumas considerações acerca das vantagens e desvantagens implícitas na sua utilização como meio de realização de políticas públicas.

Dentre as vantagens da utilização das normas tributárias como instrumentos de políticas de gastos públicos, visando a atingir objetivos sociais e econômicos, substituindo subvenções diretas, apontam-se ${ }^{61}$ :

(i) o encorajamento do setor privado a engajar-se em projetos nos quais o governo tem um papel relevante, sendo que o Estado passa a suportar apenas parte dos custos totais da atividade do particular praticada no interesse público;

\footnotetext{
${ }^{60}$ SUNLEY, Emil, Tax expenditures in the United States: experience and practice, in SWIFT, Zhicheng Li, BRIXI, Hana Polackova, VALENDUC, Christian (orgs.), Tax expenditures - shedding light on government spending through the tax system, Washington DC, The World Bank, 2004, p. 166.

${ }^{61}$ SWIFT, Zhicheng Li, BRIXI, Hana Polackova, VALENDUC, Christian, Tax expenditures: general concept, measurement, and overview of country practices, in SWIFT, Zhicheng Li, BRIXI, Hana Polackova, VALENDUC, Christian (orgs.), Tax expenditures - shedding light on government spending through the tax system, Washington DC, The World Bank, 2004, p. 3. SCHOUERI, Luís Eduardo, Normas tributárias indutoras e intervenção econômica, Rio de Janeiro, Forense, 2005, p. 105. SHI, Yaobin, Establishing a tax expenditure administrative system that achieves a sound fiscal system in China, in SWIFT, Zhicheng Li, BRIXI, Hana Polackova, VALENDUC, Christian (orgs.), Tax expenditures - shedding light on government spending through the tax system, Washington DC, The World Bank, 2004, p. 185.
} 
(ii) a promoção da decisão privada, via mercado, possibilitando a atração de mais agentes privados, quando comparada à concessão de subvenções diretas;

(iii) a redução da necessidade de supervisão governamental dos gastos;

(iv) as formulações legais são relativamente estáveis, facilitando aos contribuintes a tomada de decisões quanto à produção e à realização de operações;

(v) as subvenções tributárias podem cobrir áreas que as subvenções diretas não conseguiriam atingir;

(vi) as subvenções tributárias são mais efetivas, enquanto as subvenções diretas são efetivas apenas após passar por complicados procedimentos orçamentários;

(vii) as subvenções tributárias atraem o capital estrangeiro e aumentam as oportunidades de negócios com o exterior.

Todavia, há uma série de argumentos contrários à utilização das normas tributárias para veicular subvenções. Dentre eles, apontam-se os seguintes ${ }^{62}$ :

(i) inefetividade em relação à política visada, pois as subvenções tributárias podem não ser suficientes para gerar o estímulo de mercado necessário, ou o estímulo visado pode ser anulado pelos efeitos de outras normas tributárias, nacionais ou estrangeiras.

(ii) ineficiência em relação às políticas visadas: muitas vezes as subvenções tributárias são editadas em resposta a pleitos de grupos individuais, e não como parte de programas de gastos previamente planejados e avaliados. Com isso, tornam-se instrumentos ineficientes para a realização de políticas públicas concretas.

62 SWIFT, Zhicheng Li, BRIXI, Hana Polackova, VALENDUC, Christian, Tax expenditures: general concept, measurement, and overview of country practices, in SWIFT, Zhicheng Li, BRIXI, Hana Polackova, VALENDUC, Christian (orgs.), Tax expenditures - shedding light on government spending through the tax system, Washington DC, The World Bank, 2004, p. 5. Cf. SCHOUERI, Luís Eduardo, Normas tributárias indutoras e intervenção econômica, Rio de Janeiro, Forense, 2005, p. 105. 
(iii) ausência de neutralidade do sistema tributário: a existência de subvenções tributárias em um sistema tributário torna-o veículo explícito para a indução de comportamentos. O tributo que, em si, já não é neutro, passa a ser usado para realizar a indução. Um sistema tributário ótimo seria, em princípio, o mais neutro possível, não alterando a alocação de recursos pelos mecanismos de mercado (viabilizando, assim, o maior grau de eficiência alocativa possível). Os objetivos de indução são justificados se eles se prestam a corrigir alguma falha do mercado que não permita a realização da alocação adequada dos recursos ou, por outro lado, se realizam algum outro objetivo, como, por exemplo, a distribuição de recursos mais justa ${ }^{63}$. Contudo, pelos motivos explicitados acima (em "i" e "ii"), as subvenções tributárias muitas vezes falham na realização de qualquer política e, ainda assim, geram grande custo em termos de eficiência.

(iv) desrespeito à igualdade: as subvenções tributárias geram problemas tanto no que tange à igualdade horizontal quanto à vertical. Do ponto de vista da igualdade horizontal, não há garantia de que dois contribuintes na mesma situação valer-se-ão da mesma maneira dos benefícios. Do ponto de vista da igualdade vertical, notamos que as subvenções tributárias beneficiam mais os contribuintes com maior renda. Os contribuintes com prejuízo, por exemplo, geralmente não recebem qualquer benefício, enquanto aqueles altamente lucrativos (que, portanto, arcariam com maior carga tributária em um quadro sem a subvenção tributária) são os mais beneficiados. A situação pode se agravar se o imposto for progressivo e o benefício fiscal não contar com qualquer meio ${ }^{64}$ para considerar este fator.

(v) impossibilidade de avaliações periódicas ${ }^{65}$ : diferentemente de políticas de gastos diretos, que (teoricamente) podem ser avaliadas e repensadas durante a elaboração de cada orçamento ${ }^{66}$, as subvenções tributárias, após serem

\footnotetext{
${ }^{63}$ Ver tópico I.3.1 adiante para aprofundamento nesta discussão.

${ }^{64}$ Por exemplo, obrigar que as deduções sejam feitas primeiro das faixas de alíquota mais baixas, ou gerar créditos restituíveis para contribuintes que não tenham tributo a pagar.

${ }^{65}$ Cf. BROWN, Colin, Tax expenditures in Australia, in SWIFT, Zhicheng Li, BRIXI, Hana Polackova, VALENDUC, Christian (orgs.), Tax expenditures - shedding light on government spending through the tax system, Washington DC, The World Bank, 2004, p. 47.

${ }^{66}$ Supõe-se, neste caso, orçamento não engessado (i.e., orçamento que não tenha vinculação prévia de gastos).
} 
instituídas, não são passíveis de reavaliações periódicas. A reavaliação ocorreria apenas em projetos de alteração da legislação tributária, sendo, assim, menos orgânica e mais engessada do que aquela feita no orçamento, aplicável às subvenções diretas. Há, deste modo, o risco de uma subvenção tributária que parou de cumprir os seus objetivos permanecer no ordenamento apenas pela falta de motivação para retirá-la.

(vi) ausência de limitação nos gastos governamentais: não é possível especificar de antemão quantos contribuintes efetivamente se valerão das subvenções tributárias, razão pela qual elas podem se tornar políticas de gastos ilimitadas, sem a possibilidade de se estimar a quantidade de recursos empregados. Esta ausência de limites pode gerar sérios problemas quanto à eficiência alocativa no mercado e à eficiência da política de gastos empregada.

(vii) erosão da base tributável: o excesso de cortes na base da tributação pode tornála limitada e incompreensível, abrindo grande margem para planejamentos. Além disso, os contribuintes que não gozam dos benefícios arcarão com altas alíquotas para compensar a perda de arrecadação advinda das subvenções tributárias.

(viii) aumento da complexidade da legislação tributária e dos custos de conformidade e de fiscalização: a inserção de políticas de gastos na legislação tributária torna-a mais complexa, sendo que tal complexidade pode afetar mesmo os contribuintes não relacionados às políticas de gastos inseridas. A complexidade, além de abrir margem para a elisão fiscal, gera custos de conformidade para os contribuintes ${ }^{67}$. A atividade de fiscalização também se torna mais complexa e custosa ${ }^{68}$.

\footnotetext{
${ }^{67}$ Ressalte-se que estes custos de conformidade são geralmente regressivos, ou seja, "pesam" mais para os contribuintes com menor capacidade contributiva.

${ }^{68}$ Neste ponto, cabe salientar que o aumento de custo de arrecadação pode não ser em si uma desvantagem ao se compararem as subvenções tributárias com as subvenções diretas. Se a realização de uma política por meio de subvenções diretas gerasse um custo administrativo de implementação maior do que o custo de fiscalização gerado pela subvenção tributária necessária para implementar esta mesma política, a subvenção tributária seria, neste quesito, mais vantajosa.
} 
(ix) impossibilidade de apuração do tamanho do Estado ${ }^{69}$ : quando são utilizadas subvenções tributárias para a realização de políticas públicas, a sensação do tamanho do Estado pode ser menor do que ele realmente é. Com efeito, quando o Estado arrecada e gasta em programas de políticas públicas, a atuação estatal é perceptível para a sociedade, que tem maior referência acerca do tamanho do setor de serviços públicos e da intervenção do Estado no domínio econômico. Por outro lado, se esta mesma atuação dá-se por meio de subvenções veiculadas por normas tributárias, o Estado aparentemente arrecada e gasta menos (pois gasta por meio da não-arrecadação), parecendo que está se abstendo de realizar qualquer intervenção no domínio econômico, quando efetivamente o faz.

Tendo em vista este cenário de vantagens e desvantagens, Lenjosek $^{70}$ aponta que a avaliação das subvenções tributárias pede que se determine o seu desempenho de acordo com os seguintes critérios:

(i) relevância: indaga-se se a medida tributária é consistente com as prioridades de política e se ela realmente atende à necessidade apontada;

(ii) efetividade: indaga-se se a medida tributária efetivamente atinge os seus objetivos, dentro do orçamento esperado e sem resultados indesejados;

(iii) eficiência: indaga-se se a medida tributária é o meio mais apropriado e eficiente para atingir os objetivos previstos, quando comparada com outros tipos de medidas.

Ende, Haberham e Boogert $^{71}$ ainda ressaltam que, antes da decisão pela realização de uma política pública por meio de gastos (tax expenditure ou subvenção direta), deve-se contemplar se esta via (i.e., do gasto público) seria a mais adequada,

69 BROWN, Colin, Tax expenditures in Australia, in SWIFT, Zhicheng Li, BRIXI, Hana Polackova, VALENDUC, Christian (orgs.), Tax expenditures - shedding light on government spending through the tax system, Washington DC, The World Bank, 2004, p. 47.

${ }^{70}$ LENJOSEK, Gordon J., A framework for evaluating tax measures and some methodological issues, in SWIFT, Zhicheng Li, BRIXI, Hana Polackova, VALENDUC, Christian (orgs.), Tax expenditures - shedding light on government spending through the tax system, Washington DC, The World Bank, 2004, p. 19.

${ }^{71}$ ENDE, Leo van den, HABERHAM, Amir, BOOGERT, Kees den, Tax expenditures in the Netherlands, in SWIFT, Zhicheng Li, BRIXI, Hana Polackova, VALENDUC, Christian (orgs.), Tax expenditures - shedding light on government spending through the tax system, Washington DC, The World Bank, 2004, pp. 142-143. 
quando comparada com outros veículos de políticas públicas, como as sanções jurídicas ${ }^{72}$ e os instrumentos de informação. Uma vez que se optasse pela política de gastos, a adoção das subvenções tributárias dependeria da resposta às seguintes questões: (i) há um problema claro e não ambíguo definido? (ii) há a definição de uma política clara e não ambígua? (iii) é possível demonstrar que uma intervenção financeira é necessária? (iv) é possível demonstrar que a subvenções tributárias são mais desejáveis do que a subvenção direta? e (v) é possível realizar uma adequada avaliação da subvenção tributária?

\section{I.3. Orçamentos}

Da necessidade de identificação das subvenções tributárias exigida pelas teorias que as reconhecem, nascem listas ou "orçamentos", que são documentos que, independentemente de sua natureza jurídica em um determinado ordenamento, apresentam a medida da receita que decorre dos desvios do parâmetro da tributação. Em outras palavras, o orçamento apresenta o montante dos gastos públicos veiculados por meio de subvenções tributárias.

Note-se que não há qualquer consenso internacional acerca do formato destes orçamentos, nem da sua relevância e natureza jurídica. Esta ausência de consenso decorre, principalmente, dos seguintes fatores: (i) conforme mencionado, não há consenso acerca de quais normas constituem o parâmetro do sistema e quais são subvenções tributárias, o que implica a impossibilidade de comparação internacional dos $\operatorname{orçamentos~}^{73}$; (ii) a classificação dos gastos varia nos $\operatorname{orçamentos~}^{74}$; (iii) a obrigação legal da produção do

${ }^{72}$ Acerca da opção entre políticas de indução ou proibição, cf. SCHOUERI, Luís Eduardo, Normas tributárias indutoras e intervenção econômica, Rio de Janeiro, Forense, 2005, pp. 41-54.

${ }^{73}$ SWIFT, Zhicheng Li, BRIXI, Hana Polackova, VALENDUC, Christian, Tax expenditures: general concept, measurement, and overview of country practices, in SWIFT, Zhicheng Li, BRIXI, Hana Polackova, VALENDUC, Christian (orgs.), Tax expenditures - shedding light on government spending through the tax system, Washington DC, The World Bank, 2004, pp. 6-7.

${ }^{74}$ A classificação pode ser feita ao menos de três formas diversas, quais sejam, (i) pela função econômica; (ii) pelo contribuinte afetado; e (iii) pelo parâmetro ao qual a tax expenditure se relaciona. No primeiro caso, as tax expenditures, assim como os gastos públicos, serão divididas de acordo com as políticas governamentais que pretendem realizar. No segundo caso, identifica-se o contribuinte que é beneficiário da medida. Contudo, a referida identificação pode não dizer muito acerca dos resultados efetivamente proporcionados pela tax expenditure, uma vez que a identificação dá-se com base na incidência jurídica. Com efeito, dependendo das condições de mercado, a incidência econômica pode variar, sendo que o beneficiário efetivo da medida também variará. No terceiro caso, dividem-se as tax expenditures de acordo com a divisão dos sistemas tributário parâmetro dos quais elas desviam. BROWN, Colin, Tax expenditures in Australia, in 
referido orçamento, ou a mera faculdade em fazê-lo, varia de país para país ${ }^{75}$; e (iv) enquanto na maioria dos países este instrumento tem valor exclusivamente informativo, alguns países buscam incorporá-lo na concepção do orçamento de gastos, ou ao menos utilizá-lo como meio para a determinação de tetos nos gastos de subvenções tributárias ${ }^{76}$.

Conforme apontamos, no Brasil a Receita Federal elabora demonstrativos anuais de gastos governamentais de natureza tributária em obediência ao parágrafo $6^{\circ}$ do artigo 165 da Constituição Federal e ao inciso II do artigo $5^{\circ}$ da Lei Complementar $n^{\circ}$ 101/00. Estes demonstrativos regionalizados do efeito - sobre as receitas e despesas- decorrente de isenções, anistias, remissões, subsídios e benefícios de natureza tributária, financeira e creditícia, deve acompanhar o projeto de lei orçamentária anual.

A explicitação dos gastos realizados por meio de normas tributárias permite ao governo e à sociedade identificar o montante de verbas empregado na realização de políticas públicas individuais, aumentando, assim, a sua transparência e o seu controle. Ainda, tendo conhecimento dos custos envolvidos na realização de uma determinada política, é possível realizar uma análise de custo-benefício mais completa e testar a eficiência dos gastos, verificando a sua real necessidade e se seria mais adequado substituir a subvenção tributária por outro tipo de política ou gasto ${ }^{77}$.

SWIFT, Zhicheng Li, BRIXI, Hana Polackova, VALENDUC, Christian (orgs.), Tax expenditures - shedding light on government spending through the tax system, Washington DC, The World Bank, 2004, p. 55.

${ }_{75}$ A Australia, a Austria, a Belgica, a França a Alemanha, a Italia e os Estados Unidos possuem regras que exigem a produção dos orçamentos. Já no Canadá, na Holanda e no Reino Unido, a produção é facultativa. SWIFT, Zhicheng Li, BRIXI, Hana Polackova, VALENDUC, Christian, Tax expenditures: general concept, measurement, and overview of country practices, in SWIFT, Zhicheng Li, BRIXI, Hana Polackova, VALENDUC, Christian (orgs.), Tax expenditures - shedding light on government spending through the tax system, Washington DC, The World Bank, 2004, p. 9.

${ }^{76}$ Idem, ibidem, p. 7. SHI, Yaobin, Establishing a tax expenditure administrative system that achieves a sound fiscal system in China, in SWIFT, Zhicheng Li, BRIXI, Hana Polackova, VALENDUC, Christian (orgs.), Tax expenditures - shedding light on government spending through the tax system, Washington DC, The World Bank, 2004, pp. 183-184.

${ }^{77}$ SWIFT, Zhicheng Li, BRIXI, Hana Polackova, VALENDUC, Christian, Tax expenditures: general concept, measurement, and overview of country practices, in SWIFT, Zhicheng Li, BRIXI, Hana Polackova, VALENDUC, Christian (orgs.), Tax expenditures - shedding light on government spending through the tax system, Washington DC, The World Bank, 2004, p. 9. ENDE, Leo van den, HABERHAM, Amir, BOOGERT, Kees den, Tax expenditures in the Netherlands, in SWIFT, Zhicheng Li, BRIXI, Hana Polackova, VALENDUC, Christian (orgs.), Tax expenditures - shedding light on government spending through the tax system, Washington DC, The World Bank, 2004, p. 138. 
Nesses termos, Brown ${ }^{78}$ aponta que o orçamento australiano teria dois objetivos principais, quais sejam: (i) descrever o parâmetro do sistema tributário e a medida em que as normas desviam deste parâmetro, de modo a informar o debate público e contribuir para a discussão do sistema tributário; e (ii) facilitar a avaliação das subvenções tributárias ao lado dos gastos diretos, possibilitando verificar se os objetivos da política visada estão sendo cumpridos a um custo razoável, além de permitir a comparação da efetividade da medida em relação aos gastos diretos.

Sunley $^{79}$, ao analisar a experiência norte-americana de 35 anos de orçamento de tax expenditures, avalia que este orçamento, enquanto instrumento analítico, ainda não atingiu todo o seu potencial. Para o autor, a avaliação do orçamento deve incluir a sua capacidade em cumprir os seguintes objetivos: (i) aumentar a transparência; (ii) facilitar a identificação e avaliação do trade-off entre as tax expenditures e os programas de gastos diretos; e (iii) cumprir o seu papel como estopim de reformas tributárias, caso as tax expenditures identificadas sejam consideradas desnecessárias.

\section{I.3.1. Primeiro passo para o orçamento: definição do parâmetro}

Para que se possa se elaborar o orçamento das subvenções tributárias é necessário identificá-las e quantificá-las.

Conforme já apontado, a identificação de uma subvenção tributária depende da determinação de uma estrutura parâmetro, pois as subvenções seriam desvios deste parâmetro. Comparando-se o parâmetro e os desvios, é possível determinar a sua natureza

\footnotetext{
${ }^{78}$ BROWN, Colin, Tax expenditures in Australia, in SWIFT, Zhicheng Li, BRIXI, Hana Polackova, VALENDUC, Christian (orgs.), Tax expenditures - shedding light on government spending through the tax system, Washington DC, The World Bank, 2004, p. 46.

${ }^{79}$ SUNLEY, Emil, Tax expenditures in the United States: experience and practice, in SWIFT, Zhicheng Li, BRIXI, Hana Polackova, VALENDUC, Christian (orgs.), Tax expenditures - shedding light on government spending through the tax system, Washington DC, The World Bank, 2004, p. 165.
} 
e extensão da subvenção ${ }^{80}$. Contudo, como já adiantado, nesse campo há profundas diferenças de opinião ${ }^{81}$.

É em decorrência da dificuldade e do subjetivismo envolvidos na definição de qualquer parâmetro que Kahn e Lehman ${ }^{82}$ criticam o "absolutismo moral" implícito na teoria das tax expenditures, que cria a ilusão de uma precisão científica, sem carga valorativa, no que é, na verdade, um domínio extremamente politizado. Isto dá aos supostos “experts" o poder de impor, com pretexto científico, a sua visão do mundo ideal, buscando excluir do mundo jurídico os desvios de um parâmetro por eles concebido.

No que tange à tributação da renda, poder-se-ia argumentar que o parâmetro é dado pelo próprio conceito de renda. Mas neste ponto também há problemas. Em primeiro lugar, não há apenas um conceito de renda amplamente aceito. Belsunce ${ }^{83}$ e Thuronyi ${ }^{84}$ deixam isto claro em suas sobra obras, podendo-se distinguir, dentre outros, os conceitos de renda como acréscimo patrimonial, renda produto e renda fonte.

Poder-se-ia insistir, contudo, e argumentar que o parâmetro deveria se basear no conceito mais amplo de renda, como aquele dado pelo modelo baseado nas teorias de Shanz, Haig e Simons ${ }^{85}$ (modelo "SHS"). A renda de um indivíduo, de acordo com esta definição, é todo o seu consumo em um determinado período, somado à variação de seu patrimônio neste mesmo período ${ }^{86}$. O conceito de consumo, neste caso, inclui todos os gastos, exceto aqueles incorridos para auferir ou produzir renda ${ }^{87}$.

Todavia, a adoção do modelo SHS como parâmetro pode ser problemática. De um lado, há diversos países que expressamente negam este modelo, sendo possível notar -

${ }^{80}$ BROWN, Colin, Tax expenditures in Australia, in SWIFT, Zhicheng Li, BRIXI, Hana Polackova, VALENDUC, Christian (orgs.), Tax expenditures - shedding light on government spending through the tax system, Washington DC, The World Bank, 2004, p. 51.

${ }^{81}$ SEGUIN, Marc, GURR, Simon, Federal tax expenditures in Canada, in SWIFT, Zhicheng Li, BRIXI, Hana Polackova, VALENDUC, Christian (orgs.), Tax expenditures - shedding light on government spending through the tax system, Washington DC, The World Bank, 2004, p. 98.

${ }^{82}$ KAHN, Douglas A, LEHMAN, Jeffrey S., Tax expenditure budgets: a critical view, in 54 Tax Notes 1661 (1992) (reproduzido em CARON, Paul L., BURKE, Karen C. e McCOUCH, Grayson M.P. Federal Income Tax Anthology. Cincinnati, Ohio: Anderson1997. $2^{a}$ tiragem) 2003, pp. 310-312.

${ }^{83}$ BELSUNCE, Horacio A. García, El concepto de rédito en la doctrina y en el derecho tributario, Depalma, Buenos Aires, 1967, pp. 87-192.

${ }^{84}$ THURONYI, Victor, Comparative tax law, Kluwer, The Hague, 2003, pp. 233 e ss.

${ }^{85}$ SIMONS, Henry C., Personal income taxation, The University of Chicago Press, Chicago, 1938, 1938.

${ }^{86}$ Ou seja, $R=C+(\Delta P)$; sendo que " $\mathrm{R}$ " é renda, "C" consumo e " $\Delta \mathrm{P}$ " a variação patrimonial, que pode ser positiva ou negativa.

${ }^{87}$ BROWN, Colin, op. cit., p. 51. 
seja pela análise da legislação, seja pela própria evolução histórica do sistema - que o seus sistemas tributários claramente adotam parâmetros diversos. A propósito, basta analisar o artigo 43 do Código Tributário Nacional para notar que o sistema brasileiro não segue exatamente o modelo SHS. Contrapondo o sistema norte-americano ao britânico, também é possível perceber fortes diferenças conceituais, principalmente quanto aos ganhos de capital, bem como as razões históricas que justificam o primeiro sistema aproximar-se do modelo SHS e o último não ${ }^{88}$.

Por outro lado, mesmo os países cujos sistemas tributários aproximam-se do modelo SHS - Estados Unidos, por exemplo - não o adotam em sua inteireza. Todavia, seria quase absurdo considerar que todos os desvios do parâmetro SHS caracterizariam políticas de subvenção. As razões para tais desvios podem ser as mais diversas e considerálos todos como substitutos de políticas de gastos ridicularizaria qualquer orçamento de subvenções tributárias.

A recente mudança da política adotada nos Estados Unidos para a elaboração do orçamento, mencionada no tópico I.1 supra, mostra que a adoção de um parâmetro que remete a um modelo econômico e ideal de renda pode ser muito problemática. O novo orçamento americano, que toma as regras gerais do Internal Revenue Code como parâmetro, busca amenizar estes problemas.

No Brasil, a definição jurídica do fato gerador do imposto de renda inicia-se no artigo 153, III, da Constituição Federal, o qual outorga à União a competência para instituir este imposto, e perpassa por outros dispositivos constitucionais que determinam critérios especificamente aplicáveis ao imposto de renda - tais quais a generalidade, a universalidade e a progressividade, previstas no $\$ 2^{\circ}$, I, do artigo 153 -, bem como princípios e regras gerais aplicáveis a impostos em geral, tais quais a legalidade, anterioridade, não confisco etc.

A noção constitucional de renda é definida pelo CTN, em seu papel de lei complementar, conforme determina o artigo 146, III, "a", da Constituição Federal. O artigo 43 deste código dispõe que o fato gerador do imposto de renda é a aquisição da

\footnotetext{
${ }^{88}$ KORNHAUSER, Marjorie, The origins of capital gains taxation: what's law got to do with it?, in $39 \mathrm{Sw}$. L.J., 869 (1985) (reproduzido em CARON, Paul L., BURKE, Karen C. e McCOUCH, Grayson M.P. Federal Income Tax Anthology. Cincinnati, Ohio: Anderson1997. $2^{\mathrm{a}}$ tiragem), 2003, pp 438-442.
} 
disponibilidade econômica ou jurídica de renda, assim entendido o produto do capital, do trabalho ou da combinação de ambos, bem como de proventos de qualquer natureza, assim entendidos os acréscimos patrimoniais não compreendidos na definição de renda anterior.

Note-se que a definição de renda como produto e acréscimo patrimonial dada pelo CTN, apesar de adotar ótica diferente da definição econômica, atinge resultado igualmente amplo, sendo certo que o ordenamento brasileiro tributa tanto a renda consumida quanto a renda poupada.

Todavia, diversos outros elementos da legislação teriam de ser analisados a fim de determinar se deveriam ser considerados parte da estrutura parâmetro da tributação da renda, ou se poderiam ser qualificados como subvenções, sendo certo que haveria dúvidas em relação a diversos deles. Não obstante, explorar esta análise fugiria ao escopo da discussão pretendida no presente trabalho.

Sendo assim, apenas apontaremos a seguir alguns temas cuja consideração é importante para a determinação de um parâmetro normativo para a tributação da renda e as discussões possíveis em relação a eles:

(i) sujeito passivo: no caso da tributação das pessoas físicas, a unidade tributável pode variar entre o indivíduo ou a unidade familiar. Resta, assim, a dúvida se os ajustes da tributação para considerar dependentes, casais e outras situações de pessoas convivendo no mesmo lar são um mero ajuste à capacidade contributiva ou uma subvenção tributária ${ }^{89}$.

(ii) base de cálculo: retorna-se à questão do conceito de renda. A base de cálculo para a tributação das pessoas físicas deveria se enquadrar no conceito de capacidade contributiva. Contudo, a própria literatura econômica diverge acerca da base mais apta para tanto ${ }^{90}$, havendo quem defenda que a tributação compreensiva da renda (ou seja, o modelo SHS) seria o que mais se aproximaria da capacidade contributiva, enquanto outros defendem que a

\footnotetext{
${ }^{89}$ VALENDUC, Cristian, From tax expenditure reporting to tax policy analysis: some experience from Belgium, in SWIFT, Zhicheng Li, BRIXI, Hana Polackova, VALENDUC, Christian (orgs.), Tax expenditures - shedding light on government spending through the tax system, Washington DC, The World Bank, 2004, p. 72.

${ }^{90}$ Idem, ibidem, pp. 72-73.
} 
tributação da renda despendida (ou seja, o consumo), isentando-se a renda poupada, seria mais adequada. Além disso, o conceito de renda constante de um ordenamento pode não se adequar (e geralmente não se adéqua) a qualquer destes conceitos econômicos.

(iii) cédulas: a segregação cedular da tributação da renda (pela qual determinados rendimentos, especialmente aqueles decorrentes do capital, recebem tratamento diferenciado) não concretiza o modelo SHS e poderia ser considerada, nesse sentido, uma subvenção tributária. Contudo, dependendo da fundamentação que se adotar para a tributação diferenciada de certos rendimentos, é possível considerá-la parte do parâmetro ${ }^{91}$. Tomem-se os ganhos de capital, por exemplo. Enquanto a sua tributação é justificada pelo modelo SHS, outros conceitos de renda, como, por exemplo, de renda como o produto nacional, não justificariam a sua tributação ${ }^{92}$.

(iv) deduções e abatimentos: em regra, poder-se-ia entender que, se a dedução reflete um gasto que implica redução da capacidade contributiva, não deve ser considerada subvenção tributária. Já o gasto que representa consumo - e portanto é índice de capacidade contributiva - não deveria ser abatido ou deduzido da base de cálculo; se é deduzido, trata-se de subvenção tributária. Esta linha de raciocínio está de acordo com o modelo SHS, pois os primeiros gastos não revelariam consumo e, por isso, não configurariam renda, enquanto os segundos claramente revelariam consumo. Contudo, não é tão simples definir se determinados gastos revelam, ou não consumo, havendo grande discussão nesta área ${ }^{93}$. Ademais, se o conceito de renda adotado em um

91 VALENDUC, Cristian, From tax expenditure reporting to tax policy analysis: some experience from Belgium, in SWIFT, Zhicheng Li, BRIXI, Hana Polackova, VALENDUC, Christian (orgs.), Tax expenditures - shedding light on government spending through the tax system, Washington DC, The World Bank, 2004, p. 73

${ }^{92}$ SUNLEY, Emil, Tax expenditures in the United States: experience and practice, in SWIFT, Zhicheng Li, BRIXI, Hana Polackova, VALENDUC, Christian (orgs.), Tax expenditures - shedding light on government spending through the tax system, Washington DC, The World Bank, 2004, p. 169.

93 Confira-se, por exemplo, a discussão acerca de deduções de despesas médicas e contribuições para caridade em ANDREWS, William D., Personal deductions in an ideal income tax, 86 Harv. L. Rev. 309 (1972), (reproduzido em CARON, Paul L., BURKE, Karen C. e McCOUCH, Grayson M.P. Federal Income Tax Anthology, Cincinnati, Ohio, Anderson, 1997, $2^{\text {a }}$ tiragem, 2003)., p.277-282; GIFFITH, Thomas D., Theories of personal deductions in the income tax, 40 Hastings L.J. 343 (1989) (reproduzido em CARON, Paul L., BURKE, Karen C. e McCOUCH, Grayson M.P. Federal Income Tax Anthology. Cincinnati, Ohio, Anderson1997, $2^{\text {a }}$ tiragem, 2003), p. 287-291; KELMAN, Mark G., Personal Deductions Revisited: Why They Fit Poorly in an 'Ideal' Income Tax and Why They Fit Worse in a Far from Ideal World, 31 Stan. L. 
ordenamento divergir da renda econômica apurada conforme o método SHS, a categoria na qual se enquadram os gastos e, portanto, a definição da natureza jurídica da dedução, pode ser diversa.

(v) métodos para evitar a dupla incidência econômica: se os rendimentos auferidos pelas pessoas jurídicas forem tributados também quando distribuídos aos seus acionistas, a mesma renda será tributada duas vezes (uma como lucro da pessoa jurídica e outra como renda do acionista); trata-se de dupla incidência econômica sobre a renda. $\mathrm{O}$ sistema tributário pode ser indiferente em relação a este fenômeno, permitindo que ele ocorra ${ }^{94}$. Todavia, este caso de dupla incidência econômica afeta a neutralidade do sistema tributário quanto às formas de organização empresarial, por influenciar as decisões de um grupo econômico quanto à constituição de subsidiárias ou filiais. Afeta, ainda, a neutralidade quanto às decisões de financiamento das pessoas jurídicas, uma vez que, se tanto os rendimentos de juros quanto os rendimentos de dividendos são tributados, pode ser mais interessante capitalizar as empresas por meio de empréstimos - ainda que, afastado o fator tributário, esta não seja a opção mais eficiente -, pois as despesas com juros podem ser deduzidas quando da apuração do lucro da pessoa jurídica ${ }^{95}$, enquanto os pagamentos de dividendos não. Desta maneira, o próprio conceito econômico de renda pediria que se eliminasse a dupla incidência sobre os dividendos. Todavia, não são todos os países que adotam esta política e, ainda, os métodos para se realizar a integração podem variar. Assim, a consideração dos métodos de integração como subvenções tributárias não parece ser adequada, mas pode ser defendida ${ }^{96}$.

Rev. 831 (1979) (reproduzido em CARON, Paul L., BURKE, Karen C. e McCOUCH, Grayson M.P. Federal Income Tax Anthology. Cincinnati, Ohio: Anderson1997. $2^{\mathrm{a}}$ tiragem, 2003), p. 283-287; TURNIER, William J; Evaluating personal deductions in an income tax - the ideal, 66 Cornell L. Rev. 262 (1981) (reproduzido em CARON, Paul L., BURKE, Karen C. e McCOUCH, Grayson M.P. Federal Income Tax Anthology. Cincinnati, Ohio, Anderson1997. $2^{\mathrm{a}}$ tiragem, 2003), p. 292-295.

${ }^{94}$ Trata-se do método clássico de integração. Cf. TERRA, Ben J. M., WATTEL, Peter, J., European tax law, $4^{\mathrm{a}}$ ed., Deventer, Kluwer, 2005, p. 261.

95 Pois os pagamentos de juros são, efetivamente, renda econômica do mutuante.

${ }^{96}$ SEGUIN, Marc, GURR, Simon, Federal tax expenditures in Canada, in SWIFT, Zhicheng Li, BRIXI, Hana Polackova, VALENDUC, Christian (orgs.), Tax expenditures - shedding light on government spending through the tax system, Washington DC, The World Bank, 2004, p. 103 
(vi) tributação de rendimentos transfronteiriços: geralmente, a lei interna dos países dispõe sobre métodos para eliminar a bitributação de rendimentos de seus residentes que derivem de fonte estrangeira. Assim, ou se outorga um crédito do imposto pago no exterior, ou se isenta o rendimento. Todavia, uma vez que não há qualquer obrigação internacional vigente (além dos acordos de bilaterais para evitar a bitributação) que determine que a bitributação seja eliminada ou mitigada, há dúvidas se tais mecanismos devem ser considerados subvenções tributárias $^{97}$;

(vii) período de apuração: geralmente se entende que o período é o ano calendário para as pessoas físicas e o fiscal para as jurídicas ${ }^{98}$. Dispositivos que escapassem deste padrão e implicassem favorecimentos constituiriam, assim, subvenções tributárias. Nesse sentido, normas de carryforward e carrybackward dos prejuízos, o diferimento da tributação da renda auferida em um exercício e até mesmo regras de depreciação acelerada poderiam ser consideradas subvenções tributárias, pois desviariam do parâmetro ${ }^{99}$. Por outro lado, pode-se defender, por exemplo, que a natureza cíclica dos negócios demanda a existência de regras de carryforward, razão pela qual elas deveriam integrar o sistema parâmetro ${ }^{100}$;

(viii) consideração da inflação ${ }^{101}$ : uma vez que a parcela dos ganhos decorrentes do mero ajuste inflacionário não deveria ser considerada renda, a tributação nominal poderia ser entendida como uma penalidade. Todavia, pode haver boas razões para se desconsiderar a inflação na tributação da renda ${ }^{102}$, o que justificaria que estas regras fossem consideradas parte da estrutura parâmetro.

A análise destes itens mostra que sempre haverá dúvidas quanto ao que deve ser considerado o sistema parâmetro. A experiência internacional com os orçamentos de

${ }^{97}$ SEGUIN, Marc, GURR, Simon, Federal tax expenditures in Canada, in SWIFT, Zhicheng Li, BRIXI, Hana Polackova, VALENDUC, Christian (orgs.), Tax expenditures - shedding light on government spending through the tax system, Washington DC, The World Bank, 2004, p. 103

${ }^{98}$ Idem, ibidem, p. 102.

99 BROWN, Colin, Tax expenditures in Australia, in SWIFT, Zhicheng Li, BRIXI, Hana Polackova, VALENDUC, Christian (orgs.), Tax expenditures - shedding light on government spending through the tax system, Washington DC, The World Bank, 2004, p. 53.

${ }^{100}$ SEGUIN, Marc, GURR, Simon, op. cit., p. 102.

${ }^{101}$ BROWN, Colin, op. cit., p. 54. Cf. M. Seguin, S. Gurr, Federal tax... cit (nota 58), p. 102.

${ }^{102}$ FREEDMAN, Judith, Treatment of capital gains and losses, in ESSERS, Peter e RIJKERS, Arie (eds.), The Notion of Income from Capital, Amsterdam, IBFD, 2005, p. 208. 
subvenções tributárias confirma esta afirmação, pois todos os países apresentam dificuldades em conformar a sua estrutura parâmetro, inclusive aqueles que buscam ampará-la em algum conceito objetivo de renda.

O Demonstrativo dos Gastos Governamentais Indiretos de Natureza Tributária de $2011^{103}$ propõe que as seguintes características da "estrutura normal de tributação":

(i) Contribuintes em situações equivalentes devem estar sujeitos a obrigações similares (equidade);

(ii) Contribuintes podem estar sujeitos a obrigações progressivas em relação a sua renda (progressividade);

(iii) A tributação não deve alterar a alocação dos recursos na economia (neutralidade).

Nesse sentido, o Demonstrativo aponta que toda desoneração que implicar desvios em relação a estas características, e ao mesmo tempo tiver a intenção de promover alguma ação de governo deve ser considerada um gasto tributário. Por outro lado, a alteração que promover uma aproximação das regras tributárias a estas características deve ser considerada parte da própria estrutura tributária.

Essa ideia, em nossa visão, deve ser criticada. Há uma falha conceitual ${ }^{104}$ na premissa de que o sistema tributário divide-se em normas de arrecadação - que se orientam exclusivamente por princípios tributários, como a capacidade contributiva e eficiência - e normas de subvenção, que nada têm a ver com a arrecadação e são implementadas em prejuízo da capacidade contributiva e da própria eficiência do sistema tributário.

\footnotetext{
${ }^{103}$ RECEITA FEDERAL DO BRASIL, Demonstrativo dos Gastos Governamentais Indiretos de Natureza Tributária - 2011 (Gastos Tributários), Brasília, 2011, disponível [on line] in http://www.receita.fazenda.gov.br/publico/EstudoTributario/BensTributarios/2011/DGT2011.pdf [25.01.2011], p. 8.

${ }^{104}$ Nesse sentido, cf. KAHN, Douglas A, LEHMAN, Jeffrey S., Tax expenditure budgets: a critical view, in 54 Tax Notes 1661 (1992) (reproduzido em CARON, Paul L., BURKE, Karen C. e McCOUCH, Grayson M.P. Federal Income Tax Anthology. Cincinnati, Ohio: Anderson1997. $2^{a}$ tiragem) 2003, pp. 310-312.
} 
Sobre esse assunto, devem ser tomadas as considerações de Schoueri ${ }^{105}$, que indica que qualquer norma tributária é capaz de apresentar funções arrecadadora, simplificadora, distributiva e indutora. Para identificar tais funções, seria necessária a adoção de um enfoque pragmático, que identificasse o efeito atingido pela norma.

O enfoque pragmático mostra que todas as funções apresentadas acima podem estar simultaneamente presentes. Ao se estudar qualquer um destes efeitos (ou funções) da norma tributária, estar-se-á estudando um de seus aspectos, ou seja, realizando um corte no fenômeno e realçando uma das funções ${ }^{106}$.

Nesses termos, a ciência econômica nos mostra que todo e qualquer tributo traz consigo o efeito de induzir comportamentos. Em outras palavras, nenhum tributo é neutro $^{107}$. As decisões e comportamentos dos agentes econômicos nunca serão iguais em um ambiente sem o tributo e em outro com ele.

É justamente ao notar este caráter indutor de comportamentos dos tributos que o legislador passa a utilizá-lo a seu favor, como instrumento de intervenção "sobre" o domínio econômico ${ }^{108}$.

Tendo isso claro, pode-se afirmar que é certo que, assim como os tributos sempre arrecadarão receitas para o Estado, também influenciarão comportamentos. Em outras palavras, os efeitos de arrecadação e indução sempre serão verificados, independentemente de o legislador, ao criar o tributo, ter em mente a finalidade arrecadadora, indutora, simplificadora ou distributiva.

\footnotetext{
105 SCHOUERI, Luís Eduardo, Normas tributárias indutoras e intervenção econômica, Rio de Janeiro, Forense, 2005, pp. 17 e 27.

${ }^{106}$ Idem, ibidem, p. 30.

${ }^{107} \mathrm{O}$ tributo apenas poderia ser plenamente neutro se fosse cobrado em um mesmo montante de todos os indivíduos, independentemente de seus comportamentos (um tributo fixo per capita, por exemplo), ou se fosse cobrado por um Estado que tivesse meios para determinar exatamente a capacidade de cada indivíduo em produzir riqueza, cobrando os tributos de acordo com a referida capacidade potencial (ou seu reflexo em efetivo bem-estar), independentemente do efetivo aproveitamento de tal capacidade. Ambas as situações são infactíveis, pelos fatos de a primeira ferir ideias básicas de justiça e de a segunda ser impraticável por impossibilidade de mensuração. Opta-se, assim, pela tributação de manifestações concretas de capacidade (riqueza), o que sempre implicará a indução de comportamentos, ou, em outros termos, a ausência de neutralidade.

${ }^{108}$ GRAU, Eros Roberto, A ordem econômica na constituição de 1988, 8 ed., São Paulo, Malheiros, 2003, p. 128.
} 
A proposta pragmática mencionada acima nos mostra que a análise de tais efeitos independe da ideia inicial do legislador ao desenhar a norma tributária. Se há efeito arrecadador (como sempre há) o tributo deve dobrar-se aos princípios da ordem tributária, estruturados para lidar com normas deste tipo, como a legalidade, anterioridade, irretroatividade e a capacidade contributiva.

Por outro lado, havendo o efeito indutor (como sempre há) deve-se ter em mente que a intervenção Estatal sobre o domínio econômico gerada pela referida indução deve se dar de acordo com o modelo previsto na Constituição Econômica ${ }^{109}$ para a referida intervenção. Ou seja, a indução deve se coadunar com, e não confrontar, os princípios da Ordem Econômica constitucionalmente previstos ${ }^{110}$.

Inclusive, em um modelo constitucional de economia de mercado, tal qual o brasileiro, as intervenções estatais no domínio econômico não devem se dar em prejuízo da eficiência do mercado, mas devem visar a sua concretização. Nesse sentido, as intervenções estatais são fundamentadas em objetivos de correção de falhas de mercado ou para implementação de metas positivas estabelecidas na Constituição, que visam à correção de problemas que não seriam resolvidos no mercado sem a intervenção estatal.

Dessa maneira, a implementação de políticas públicas por meio do sistema tributário (se feita adequadamente) não representa um desvio da eficiência. Apesar de tais regras efetivamente influenciarem o comportamento dos contribuintes, elas o fazem para tornar o mercado mais eficiente. É o que Stglitz ${ }^{111}$ chama de duplo dividendo. Ou seja, transforma-se a ausência de neutralidade do tributo, que, em princípio, gera ineficiência no mercado, em meio de influenciar comportamentos de modo a corrigir falhas do mercado, tornando o mercado mais eficiente e o tributo mais neutro.

Da mesma forma, a intervenção por indução tributária não representa um desvio em relação à igualdade ou à capacidade contributiva, pois os princípios da Ordem

\footnotetext{
${ }^{109}$ GRAU, Eros Roberto, A ordem econômica na constituição de 1988, 8 ed., São Paulo, Malheiros, 2003, p. 68.

${ }^{110}$ Ademais, os efeitos indutores devem ser verificados a cada momento, quando se aplica a norma tributária, pois dependerão de uma conjuntura de fatores econômicos específica, a qual não pode ser verificada abstratamente ou ex ante (e.g. se, em um momento, a demanda de determinado produto era elástica e, por algum motivo, em um segundo momento, passa a ser inelástica, os efeitos indutores da norma tributária mudarão).

${ }^{111}$ STIGLITZ, Joseph E., Economics of the public sector, $3^{\mathrm{a}}$ ed., New York, Norton \& Company, 1999, p. 464-465.
} 
Econômica constitucional devem ser aplicados em conjunto com os princípios da Ordem Tributária, e não em substituição a eles ${ }^{112}$.

Assim, a segregação do sistema tributário em dois grupos, um de normas tributárias parâmetro, que se prestariam apenas para realizar a arrecadação, e outro de normas indutoras (ou subvenções), que se prestariam apenas para realizar política econômica, sendo cada um destes grupos guiados por princípios independentes, parece não se sustentar do ponto de vista teórico.

Por isso, a realização de políticas públicas por meio do sistema tributário não pode ser entendida como desvios de parâmetro de equidade, capacidade contributiva e neutralidade aplicáveis ao sistema tributário. Como qualquer outra norma tributária, as normas desenhadas para implementar políticas públicas devem se dobrar a estes critérios e concretizá-los.

Sendo assim, parece-nos que a análise das subvenções tributárias não deve ter como primeiro passo a identificação de um parâmetro (que concretiza a igualdade, a capacidade contributiva e a neutralidade), seguida da identificação dos desvios de tal parâmetro.

Em nossa visão, o primeiro passo deve ser identificar a concreção de uma política pública pelo sistema tributário. Identificadas as regras que concretizam a política pública em questão, será possível compará-las com outras regras que não servem a este propósito (as regras "gerais", ou “normais") e, a partir de então, calcular a subvenção.

Todavia, apesar de tal quantificação ser útil para fins informativos, deve-se sempre ter em mente a fragilidade e o subjetivismo da comparação entre a subvenção tributária e as regras "normais" do sistema.

112 SCHOUERI, Luís Eduardo, Normas tributárias indutoras e intervenção econômica, Rio de Janeiro, Forense, 2005, pp. 273 e ss. 


\section{I.3.2. Segundo passo para o orçamento: como calcular as subvenções?}

Feitas as considerações acerca da identificação das subvenções tributárias para fins de seu orçamento, cabe tecermos alguns comentários acerca dos métodos adotados para a sua mensuração.

Para estimar o custo de uma subvenção tributária, podem ser utilizados três principais métodos, em sistemáticas de caixa ou competência, quais sejam: (i) método da receita renunciada (revenue forgone); (ii) método do ganho de receita (revenue gain); e (iii) método do gasto equivalente (outlay equivalent).

O método da receita renunciada consiste no cálculo ex post da perda de receita incorrida pelo governo com uma determinada subvenção tributária. Este método não leva em conta respostas comportamentais dos contribuintes. Assim, o custo de um crédito será simplesmente o montante total de crédito dado. Da mesma maneira, o custo de determinada dedução será calculado como resultado do produto da dedução total pela alíquota marginal $^{113}$.

O método do ganho de receita consiste em um cálculo ex ante da receita adicional que seria arrecadada se a subvenção tributária fosse revogada. Neste caso, a resposta comportamental dos contribuintes tem de ser levada em conta. Para tanto, é necessário contar com estimativas de elasticidade dos mercados, a fim de saber o quanto o comportamento dos contribuintes seria alterado uma vez que o benefício fiscal fosse revogado $^{114}$.

O método do gasto equivalente calcula o gasto público capaz de gerar ao contribuinte um ganho similar àquele gerado pela subvenção tributária. O valor será igual ao calculado pelo método de receita renunciada se a subvenção não for tributável quando

\footnotetext{
${ }^{113}$ SWIFT, Zhicheng Li, BRIXI, Hana Polackova, VALENDUC, Christian, Tax expenditures: general concept, measurement, and overview of country practices, in SWIFT, Zhicheng Li, BRIXI, Hana Polackova, VALENDUC, Christian (orgs.), Tax expenditures - shedding light on government spending through the tax system, Washington DC, The World Bank, 2004, p. 7. BROWN, Colin, Tax expenditures in Australia, in SWIFT, Zhicheng Li, BRIXI, Hana Polackova, VALENDUC, Christian (orgs.), Tax expenditures - shedding light on government spending through the tax system, Washington DC, The World Bank, 2004, p. 46, aponta que o método da receita renunciada é utilizado na Austrália, pois ele fornece a informação mais confiável para calcular o nível de subvenções veiculadas pelo sistema tributário, por mostrar a diferença entre o tributo pago pelo contribuinte recebendo uma tax expenditure e o tributo pago por um contribuinte similar que não receba tal benefício.

${ }^{114}$ SWIFT, Zhicheng Li, BRIXI, Hana Polackova, VALENDUC, Christian, op. cit., p. 7.
} 
recebida pelo contribuinte. Se for, é necessário fazer o gross up pela alíquota dos tributos que incidiriam sobre a subvenção recebida ${ }^{115}$.

No caso de as subvenções tributárias não constituírem especificamente uma renúncia, mas mero diferimento da tributação - o que ocorre, por exemplo, nos casos de normas de depreciação acelerada -, pode-se utilizar uma abordagem de valor presente para computar o custo do diferimento, como se se tratasse de um empréstimo governamental a juro zero $^{116}$.

Com efeito, do ponto de vista do contribuinte, o efeito da depreciação acelerada equivale ao de um empréstimo a taxa de juros zero. Imaginem-se ativos cuja taxa normal de depreciação seja de 5 anos, a $20 \%$ por ano. Se, por algum incentivo, uma categoria especial destes ativos (benéficos ao meio ambiente, por exemplo) puder ter o seu custo total lançado como despesa logo no primeiro ano (depreciação de $100 \%$ em um ano), o efeito será que, no ano da aquisição do ativo incentivado, o contribuinte economizará, em imposto de renda, o valor do ativo multiplicado pela alíquota deste imposto (considerando que o contribuinte seja lucrativo), menos a alíquota do mesmo imposto multiplicada por $20 \%$ do custo do ativo (i.e., depreciação que normalmente seria aceita). Por outro lado, nos quatro anos seguintes, o imposto de renda devido pelo contribuinte tornar-se-á superior ao que seria devido na situação de depreciação normal, em um montante anual de $20 \%$ do custo do ativo multiplicado pela alíquota daquele imposto. Ao final dos cinco anos, o contribuinte terá pago o mesmo montante que teria pago na situação de depreciação normal; todavia, diferiu este pagamento quanto à parcela de $80 \%$ do custo do ativo multiplicado pela alíquota do imposto de renda. O diferimento, no caso, foi de $1 / 4$ do montante total diferido por ano, dentro dos quatro anos subsequentes à aquisição do bem. Ou seja, houve um empréstimo, a taxa de juros zero, de $25 \%$ deste valor pelo prazo de dois anos, $25 \%$ pelo prazo de três, $25 \%$ pelo prazo de quatro e $25 \%$ pelo prazo de cinco anos ${ }^{117}$.

\footnotetext{
115 SWIFT, Zhicheng Li, BRIXI, Hana Polackova, VALENDUC, Christian, Tax expenditures: general concept, measurement, and overview of country practices, in SWIFT, Zhicheng Li, BRIXI, Hana Polackova, VALENDUC, Christian (orgs.), Tax expenditures - shedding light on government spending through the tax system, Washington DC, The World Bank, 2004, pp. 7-8.

${ }^{116}$ Idem, ibidem, p. 8.

${ }^{117}$ ENDE, Leo van den, HABERHAM, Amir, BOOGERT, Kees den, Tax expenditures in the Netherlands, in SWIFT, Zhicheng Li, BRIXI, Hana Polackova, VALENDUC, Christian (orgs.), Tax expenditures - shedding light on government spending through the tax system, Washington DC, The World Bank, 2004, p. 145.
} 
Do ponto de vista do Estado, desconsiderando estímulos comportamentais aos contribuintes para aumentar o investimento nos ativos incentivados, a receita efetivamente renunciada pelo Estado deve ser calculada apenas nos primeiros cinco anos da concessão do incentivo mencionado acima. Isso porque, mantido o mesmo nível de investimento, a perda de receita com os contribuintes que adquirem novos ativos é compensada com o ganho de recuperação de receita do imposto de renda pago pelos contribuintes que já se utilizaram da depreciação acelerada e, nos anos subsequentes, têm a sua base de cálculo do imposto de renda aumentada.

Assim, após os cinco anos, desde que mantido o mesmo nível de investimento, a arrecadação na situação de depreciação acelerada será idêntica àquela que se daria na situação de depreciação normal. A receita renunciada, assim, equivale à perda de receitas, calculada pelo valor presente do diferimento da carga tributária apenas nos primeiros anos de concessão do benefício da depreciação acelerada (i.e., período de tempo para a recuperação de receita do primeiro benefício concedido, calculado mediante a comparação da taxa normal de depreciação com a taxa acelerada) ${ }^{118}$.

\section{I.4. Leitura e interpretação do orçamento}

É necessário algum cuidado ao interpretar os orçamentos de subvenções tributárias. Se o método da receita renunciada for adotado, há que se atentar para o fato de, conforme já mencionado, tratar-se de estimativa ex post que não leva em conta o comportamento dos contribuintes.

Assim, o método é capaz de indicar ${ }^{119}$ o valor das subvenções providas aos contribuintes em exercícios anteriores, medindo tais subvenções exclusivamente em relação à carga tributária que seria aplicável sobre o mesmo número e a mesma natureza de fatos geradores sujeitos à estrutura tributária parâmetro.

\footnotetext{
${ }^{118}$ ENDE, Leo van den, HABERHAM, Amir, BOOGERT, Kees den, Tax expenditures in the Netherlands, in SWIFT, Zhicheng Li, BRIXI, Hana Polackova, VALENDUC, Christian (orgs.), Tax expenditures - shedding light on government spending through the tax system, Washington DC, The World Bank, 2004, p. 146.

${ }_{119}$ Obviamente, com as limitações já apontadas acerca da própria definição das tax expenditures em contraposição à estrutura parâmetro.
} 
Contudo, o método da receita renunciada não é capaz de determinar o ganho de receita tributária que seria gerado, em exercícios seguintes, se a subvenção tributária fosse extinta. Isso ocorre pelo fato de tal método não fazer qualquer consideração acerca da alteração de comportamento dos contribuintes que ocorreria com a referida extinção.

Não se pode negar que o comportamento dos contribuintes é alterado pela existência de uma subvenção tributária ${ }^{120}$ e que também seria alterado se tal medida cessasse de existir. Deste modo, é irreal pensar que os fatos geradores constatados na existência da subvenção continuariam idênticos, em número e natureza, se a subvenção deixasse de existir.

Quando da cessação de uma subvenção tributária, o número de fato geradores (e.g. a quantidade de renda) dos contribuintes subvencionados provavelmente diminuiria, seja pela cessação da atividade de parte destes contribuintes, ou pela migração dessa atividade para outra área da economia. Com isso, a revogação de uma subvenção tributária geraria menos receita do que o previsto pelo método da receita renunciada. Por outro lado, se o sistema é progressivo, a eliminação de uma subvenção tributária pode gerar um ganho de arrecadação maior do que o previsto, se um grande número de contribuintes passar a recolher o tributo a alíquotas mais altas ${ }^{121}$.

Assim, o método da receita renunciada pouco diz sobre a receita que realmente seria arrecadada em uma situação parâmetro, ou seja, sem uma dada subvenção tributária. Para tal finalidade, parece mais adequado empregar o método do ganho de receita, que leva em consideração, de acordo com dados econômicos, a mudança de comportamento dos contribuintes que ocorreria na situação de ausência do benefício fiscal.

Por fim, saliente-se que, como há interação entre as subvenções existentes em um país, os custos individuais não podem ser somados para apurar o custo total ${ }^{122}$. Assim, o orçamento das subvenções tributárias é limitado a demonstrar o custo individual de cada uma destas medidas, sendo incorreto somá-los.

\footnotetext{
${ }^{120}$ Aí, inclusive, a razão de sua existência.

121 BROWN, Colin, Tax expenditures in Australia, in SWIFT, Zhicheng Li, BRIXI, Hana Polackova, VALENDUC, Christian (orgs.), Tax expenditures - shedding light on government spending through the tax system, Washington DC, The World Bank, 2004, pp. 109-110.

${ }^{122}$ SEGUIN, Marc, GURR, Simon, Federal tax expenditures in Canada, in SWIFT, Zhicheng Li, BRIXI, Hana Polackova, VALENDUC, Christian (orgs.), Tax expenditures - shedding light on government spending through the tax system, Washington DC, The World Bank, 2004, p. 97.
} 


\section{I.5. Avaliação do modelo tradicional para os fins originariamente visados}

A análise ora realizada permite concluir que a aplicação da teoria tradicional das tax expenditures, mesmo para o fim para o qual ela foi construída - i.e., a análise de políticas públicas -, pode ser problemática. Isso decorre da principal falha conceitual da teoria, qual seja, partir da premissa de que há um sistema tributário parâmetro, objetivo e claramente identificável, ao qual podem ser contrapostas as subvenções tributárias.

Ainda, há dificuldades envolvidas no próprio cálculo da receita tributária renunciada, que variará de acordo com o método escolhido.

Apesar dos problemas que apresenta, o orçamento das subvenções tributárias, se usado com a devida cautela, pode ser uma ferramenta útil para cumprir os fins para os quais foi criado (repise-se, a discussão de políticas fiscais), uma vez que se apresenta como uma valiosa ferramenta analítica.

\section{I.6. Subvenções tributárias, tributação da renda e OMC}

Conforme apontado na Introdução a este trabalho, Paul McDaniel ${ }^{123}$ - um dos idealizadores, junto com Stanley Surrey, da teoria das tax expenditures nos Estados Unidos - sugere que a teoria das tax expenditures seja utilizada para identificar as regras de tributação da renda de um Estado capazes de realizar o chamado "protecionismo de fronteira" e, portanto, estar sujeitas à contestação no âmbito da OMC.

Nesses termos, em uma tentativa de diferenciar as normas de tributação sobre a renda que não teriam qualquer efeito ou correlação com as políticas de comércio das normas tributárias que exerceriam efeitos sobre o comércio internacional, McDaniel ${ }^{124}$ aponta que, para que haja qualquer sistema tributário, um país deve estabelecer seis itens fundamentais, quais sejam: (i) Base de cálculo; (ii) Alíquotas; (iii) Fato gerador; (iv)

${ }^{123}$ MCDANIEL, Paul, The impact of trade agreements on tax systems, in INTERTAX, v. 30, issue 5, 2002, pp. 166-171 e Trade agreements and income taxation: interactions, conflicts, and resolutions, Boston, 2004, disponível [on line] in http://www.un.org/esa/ffd/aconf198-11.pdf [05.11.2005].

${ }^{124}$ Idem, ibidem, p. 167. 
Princípios contábeis; (v) Aplicação do tributo a transações transfronteiriças; e (vi) Regras administrativas.

No caso do imposto de renda, haveria, segundo McDaniel, uma visão amplamente aceita acerca do que constitui "renda" e das deduções necessárias para se alcançar a renda tributável de um contribuinte. Similarmente, seria amplamente reconhecido que um determinado país pode adotar dois possíveis métodos para a tributação de rendimentos de atividades de seus residentes no exterior (e evitar a bitributação de tais rendimentos), quais sejam: (i) o sistema de isenção (territorialidade estrita); ou (ii) a tributação da renda universal dos residentes ou nacionais, com crédito para as imposições tributárias incorridas em outros países, adotado pelos Estados Unidos e atualmente pelo Brasil, por exemplo.

Para McDaniel, tais regras, bem como os acordos bilaterais para evitar a bitributação que um determinado país tenha firmado, prestam-se a lidar com questões fundamentais atinentes à tributação da renda e, assim, constituiriam a estrutura normativa parâmetro do sistema de tributação da renda do país em questão.

Apoiado na teoria tradicional das tax expenditures, McDaniel aponta que, ao lado destas regras parâmetro, estariam as subvenções tributárias, que representam desvios de tal parâmetro e devem ser avaliadas como programas de gastos. Tais subvenções poderiam contrariar os acordos no âmbito da $\mathrm{OMC}^{125}$.

\begin{abstract}
Avi-Yonah e Slemrod ${ }^{126}$ apresentam alguns exemplos de subvenções tributárias veiculadas por normas de tributação da renda que podem realizar o "protecionismo de fronteira".
\end{abstract}

Em uma primeira categoria, são apontados os casos de utilização do sistema de tributação da renda como veículo para subsidiar exportações ou impor medidas de conteúdo local. Como exemplo, tome-se uma situação na qual um país permite que as empresas residentes somente deduzam, para fins de apuração da base de cálculo do imposto de renda, os gastos com insumos produzidos localmente. Esta política obteria o

\footnotetext{
${ }^{125}$ Veja análise nos capítulos seguintes deste trabalho.

${ }^{126}$ AVI-YONAH, Reuvem S., SLEMROD, Joel, (How) should trade agreements deal with income tax issues?, disponível [on line] in www.law.umich.edu/centersandprograms/olin/papers.htm [=http://papers.ssrn.om/abstract=285345] [23.10.2005], pp. 7 e 8.
} 
mesmo resultado que a permissão da dedutibilidade de qualquer insumo (nacional ou estrangeiro) e a imposição de uma tarifa de importação à mesma alíquota que o imposto de renda sobre as pessoas jurídicas ${ }^{127}$.

Por outro lado, em uma segunda categoria, um país poderia se valer da premissa de que subsidiar um determinado bem a uma dada alíquota seria equivalente a subsidiar todos os seus insumos ou fatores de produção a esta mesma alíquota ${ }^{128}$. Assim, um subsídio à produção pode ser atingido mediante a tributação da renda diferenciada (mais baixa) sobre todos os fatores utilizados por um determinado setor da produção. A produção nacional de automóveis, por exemplo, pode ser subsidiada mediante a tributação preferencial da renda do trabalho e/ou do capital utilizado na sua produção ${ }^{129}$.

Outro meio de se atingir a especificidade setorial que caracteriza os subsídios, mantendo a tributação sobre a renda uniforme, seria mediante a manipulação de aspectos da tributação sobre a renda referentes ao tratamento dos bens de capital do setor. Assim, a manipulação de taxas de depreciação, contabilização de estoques, ajustes de inflação, dentre outros, poderiam fazer as vezes de subsídios a determinado setor.

A aplicação da teoria das tax expenditures no âmbito da OMC implica que o Órgão de Solução de Controvérsias deverá determinar se determinadas regras de tributação da renda constantes do ordenamento dos Estados-membros configuram subvenções tributárias. Com base em tal determinação pode surgir, inclusive, a possibilidade da aplicação de medidas compensatórias.

\footnotetext{
${ }^{127}$ Avi-Yonah e Slemrod reconhecem que esta política em particular somente seria aplicável para insumos, mas não para bens de consumo. No entanto, para bens de consumo, o sistema de tributação da renda das pessoas físicas poderia ser utilizado para produzir o mesmo efeito. Imagine-se um crédito de $10 \%$ de imposto de renda para a aquisição de automóveis nacionais. AVI-YONAH, Reuvem S., SLEMROD, Joel, (How) should trade agreements deal with income tax issues?, disponível [on line] in www.law.umich.edu/centersandprograms/olin/papers.htm $\quad$ [=http://papers.ssrn.om/abstract=285345] [23.10.2005], p. 8.

${ }^{28}$ Idem, ibidem, pp. 7 e 8.

129 Avi-Yonah e Slemrod ainda mostram que a tributação da renda sobre os fatores de produção, mesmo nas hipóteses em que ela seja uniforme, e não setorial, seria relevante para o impacto na produção de um determinado país. Os autores apontam que, devido à variada intensidade da utilização dos fatores nos diferentes setores de produção, qualquer redução na tributação sobre estes fatores (que não seja uniforme para todos eles) implicaria efeito diferenciado no custo dos produtos. O fenômeno é conhecido como o efeito de tributo sobre o consumo da tributação da renda dos fatores. Assim, uma redução uniforme na tributação do trabalho, por exemplo, diminuiria o custo de produção dos bens para cuja produção se utilize intensamente o trabalho. Idem, ibidem, p. 8.
} 
Ou seja, o Órgão de Solução de Controvérsias terá que decidir acerca do que constitui o sistema "normal" ou parâmetro de um Estado Membro, avaliando determinadas medidas em relação a este parâmetro.

No caso FSC/ETI, o Órgão de Solução de Controvércias (“OSC”) reconheceu que a OMC não obriga qualquer de seus membros a tributar determinados rendimentos, ou a estabelecer os seus sistemas tributários de uma ou outra maneira ${ }^{130}$. O OSC amparou esta conclusão no fato de o parâmetro por ele construído sempre se basear nas próprias normas tributárias do Estado-membro em questão. Apenas medidas que fogem deste parâmetro normativo contrariariam os acordos sob a OMC.

Todavia, conforme vimos, mesmo um parâmetro construído com base no ordenamento do próprio Estado-membro continua sendo subjetivo. Os ordenamentos jurídicos dos Estados-membros não contam com qualquer divisão explícita entre "regras parâmetro" e "regras desvio". A concepção do parâmetro, assim, caberá ao intérprete - no caso, o OSC - que, ao observar o ordenamento, separará as regras que, na sua visão, são parâmetro daquelas outras que ele conceber como subvenções tributárias.

Nos próximos capítulos, analisaremos o GATT, o Acordo TRIMS, o ASMC e o GATS a fim de verificar quais os fundamentos jurídicos para a aplicação destes acordos a medidas de tributação da renda dos Estados-membros da $\mathrm{OMC}$, bem como se a identificação das subvenções tributárias é suficiente para resolver os casos em que tal aplicação ocorre.

${ }^{130}$ Ver Capítulo III adiante. 


\section{II - GATT E TRIMS}

Neste capítulo, analisaremos a maneira pela qual o GATT e o Acordo TRIMS aplicam-se à tributação da renda.

Para tanto, traçaremos um panorama das principais regras destes acordos e determinaremos as hipóteses em que a sua interpretação admite que elas afetem medidas de tributação da renda adotadas pelos Estados Membros da OMC.

Ademais, identificaremos alguns casos concretos em que regras de tributação da renda podem ser consideradas contrárias a estes acordos.

Por fim, avaliaremos se o modelo das subvenções tributárias descrito no Capítulo I supra é aplicável para identificar as medidas de tributação da renda que se sujeitam à aplicação destes acordos.

\section{II.1. Visão geral das regras relevantes do GATT}

Um signatário do GATT está obrigado a não aumentar as suas tarifas de importação acima de alíquotas específicas acordadas nas negociações do GATT e incorporadas nos seus anexos.

O propósito deste acordo é garantir maior certeza nas relações comerciais, por meio de um "teto" nas tarifas que não pode ser ultrapassado, sob pena de obrigação de compensação entre os parceiros comerciais afetados ${ }^{131}$.

A pedra de toque desse sistema, e provavelmente o seu princípio mais relevante para medidas tributárias ${ }^{132}$, é a não discriminação ${ }^{133}$. Dividida em duas regras principais, a não discriminação tem como objetivo primordial garantir: (i) que as medidas de política comercial impostas por um país sejam aplicadas de maneira igual a todos os

131 DALY, Michael, The WTO and direct taxation, 2005, disponível [on line] in http://www.wto.org/english/res_e/booksp_e/discussion_papers9_e.pdf [23-10-2010], p. 4.

${ }_{132}$ MOTA, Pedro Infante, $O$ princípio da não discriminação no sistema GATT/OMC, in Revista Fórum de Direito Tributário n ${ }^{\circ} 24,2006$, p. 34.

${ }^{133}$ DALY, Michael, op. cit., p. 4. 
outros Estados membros (Tratamento da Nação Mais Favorecida, constante do Art. I do GATT); e (ii) que não haja discriminação entre produtos nacionais e estrangeiros (Tratamento Nacional, constante do Art. III do GATT) ${ }^{134}$.

Assim, as regras de Tratamento da Nação Mais Favorecida e de Tratamento Nacional lidam com obrigações que visam a permitir que os produtos importados possam competir em condição de igualdade entre si e com os nacionais. Desse modo, evitam que os compromissos de tarifas assumidos sob o acordo sejam esvaziados por meio de medidas internas discriminatórias ${ }^{135}$.

Da mesma maneira, as regras sobre subsídios do GATT procuram evitar que os compromissos tarifários assumidos sob o artigo II deste acordo sejam frustrados por determinados subsídios a produtos nacionais.

A seguir aprofundaremos a análise destas regras do GATT e sua aplicação à matéria tributária, especificamente no que diz respeito à tributação da renda.

\section{II.1.1. Nação mais favorecida}

A faceta da regra de não discriminação consubstanciada no Tratamento da Nação Mais Favorecida é consagrada no artigo I:1 do GATT, o qual exige que:

“Qualquer vantagem, favor, imunidade ou privilégio concedido por uma Parte Contratante em relação a um produto originário de ou destinado a qualquer outro país, será imediata e incondicionalmente estendido ao produtor similar, originário do território de cada uma das outras Partes Contratantes ou ao mesmo destinado."

\footnotetext{
${ }^{134}$ FALIS, Stefan, The aplicability of art. I and art. III of GATT to direct taxes, in HERDIN-WINTER, Judith, HOFBAUER, Ines (org.), The relevance of WTO law for tax matters, Wien, Linde, 2006, p. 39.

${ }^{135}$ SINGH, Chandrajit, Non-discrimination in tax matters in the GATT - National Tratment, in J. HerdinWinter, I. Hofbauer (org.), The relevance of WTO law for tax matters, Wien, Linde, 2006, p. 52.
} 
De acordo com essa regra, concessões dadas aos bens de um país devem ser estendidas aos bens de todos os países membros ${ }^{136}$. A regra da Nação Mais Favorecida garante, portanto, neutralidade de importação quanto aos $\operatorname{produtos}^{137}$.

Nas palavras do Órgão de Apelação: “o objetivo e o fim do $n^{o} 1$ do artigo I consistem em proibir a discriminação entre produtos similares originários ou com destino a países diferentes. A proibição de discriminação pelo artigo I serve também como um incentivo para a extensão a qualquer Membro, numa base de nação mais favorecida, das concessões negociadas reciprocamente ${ }^{\text {"138. }}$.

Note-se, em relação ao Tratamento da Nação Mais Favorecida, que ${ }^{139}$ :

(i) Ele se aplica tanto às importações quanto às exportações.

(ii) Aplica-se incondicional e automaticamente, pois uma vantagem concedida por um Membro X a um País A deve ser concedida a todos os outros Membros, não importando se estes Membros cumprem as condições impostas pelo Membro X ao País A.

(iii) Abrange as vantagens concedidas a Membros e não membros da OMC (ou seja, vantagens concedidas a não membros também devem ser estendidas aos Membros).

(iv) Aplica-se:

a. A direitos aduaneiros e a imposições de qualquer espécie que incidam sobre as importações ou exportações ou sejam aplicadas por ocasião das importações ou exportações;

\footnotetext{
${ }^{136}$ Note-se que o artigo XXIV permite que exceção a esta regra quanto a acordos de comércio regionais e bilaterais, desde que estes acordos preferenciais (e, portanto, discriminatórios), cubram substancialmente todo o comércio entre as partes.

137 DALY, Michael, The WTO and direct taxation, 2005, disponível [on line] in http://www.wto.org/english/res_e/booksp_e/discussion_papers9_e.pdf [23-10-2010], p. 4.

${ }^{138}$ Relatório do Órgão de Apelação no caso Canada-Certain Measures Affecting the the Automotive Industry, 31.05.2000, parágrafo 84. MOTA, Pedro Infante, O princípio da não discriminação no sistema GATT/OMC, in Revista Fórum de Direito Tributário n 24, 2006, p. 35.

${ }^{139}$ Idem, ibidem, p. 35-42.
} 
b. Às imposições que incidam sobre as transferências internacionais de fundos destinadas ao pagamento de importações ou exportações;

c. Ao modo de percepção dos direitos aduaneiros e outras imposições;

d. A todas as regulamentações e formalidades relativas às importações e exportações;

e. A todas as questões objeto dos parágrafos 2 e 4 do artigo III do GATT, artigo este que lida com o Tratamento Nacional.

(v) Aplica-se a todos os produtos, e não apenas àqueles consolidados nas listas de concessões referidas no artigo II do GATT.

(vi) Aplica-se à discriminação de direito e de fato ${ }^{140}$.

(vii) Aplica-se a omissões e isenções que confiram uma vantagem ${ }^{141}$.

(viii) Tem a similaridade entre os produtos analisados como requisito para a sua aplicação ${ }^{142}$.

Conforme aponta Mota ${ }^{143}$, o Tratamento da Nação Mais Favorecida possibilita que todos os membros partilhem as vantagens resultantes da redução ou eliminação dos obstáculos ao comércio. Evita-se que os países tenham que ajustar e renegociar acordos comerciais em face de qualquer alteração de sua situação comercial, além de prevenir a distorção dos mercados mundiais (visto que todos os Estados Membros recebem o mesmo tratamento), garantindo assim a maior observância da teoria das vantagens comparativas de David Ricardo, bem como a multiplicação e aceleração dos efeitos da liberalização comercial.

\footnotetext{
${ }^{140}$ Relatório do Órgão de Apelação no caso Canada - Certain Measures Affecting the Automotive Industry, 31.05.2000, parágrafo 78 .

${ }^{141}$ Relatório do Painel adotado em 2 de fevereiro de 1988 no caso United States - Customs User Fee, parágrafo 122: "Isenções da taxa caem dentro da categoria 'vantagens, favores, privilégios ou imunidades' que o artigo I:1 exige que sejam estendidas incondicionalmente a todos os outros membros da OMC".

${ }_{142}$ Sendo que a similaridade, conforme alerta Rosembuj, é uma das definições mais complexas de se alcançar, devendo ser verificada caso a caso. ROSEMBUJ, Tulio, Taxes and the World Trade Organization, in INTERTAX v. 35, issue 6/7, 2007, p. 348

${ }^{143}$ MOTA, Pedro Infante, O princípio da não discriminação no sistema GATT/OMC, in Revista Fórum de Direito Tributário no 24, 2006, p. 49.
} 
O texto do artigo I:1 parece deixar claro que tal tratamento deve ser principalmente aplicado a tributos aduaneiros e cobranças de qualquer tipo, sendo que apenas medidas impostas sobre, ou em conexão com, a importação ou exportação de produtos estão cobertas. Todavia, o artigo I faz referência expressa aos parágrafos $2^{\circ}$ e $4^{\circ}$ do artigo III, estendendo a sua aplicação a todos os assuntos referidos em tais parágrafos $^{144}$.

A possibilidade de aplicação do Tratamento da Nação Mais Favorecida à tributação da renda dependerá essencialmente dessa extensão e será analisada no tópico II.2.3.3 infra.

\section{II.1.2. Tratamento nacional}

O tratamento nacional é a segunda faceta do princípio da não discriminação, que suporta o regime multilateral do GATT. Esta regra vem ganhando cada vez mais relevância devido à gradual redução das tarifas pelos Estados Membros e sua substituição por opacas barreiras não tarifárias ${ }^{145}$.

Nesses termos, a regra de tratamento nacional do artigo III:1 determina que:

"impostos e outros tributos internos, assim como leis, regulamentos e exigências relacionadas com a venda, oferta para venda, compra, transporte, distribuição ou utilização de produtos no mercado interno $e$ as regulamentações sobre medidas quantitativas internas que exijam a mistura, a transformação ou utilização de produtos, em quantidade e proporções especificadas, não devem ser aplicados a produtos importados ou nacionais, de modo a proteger a produção nacional."

Ademais, o artigo III:2 exige que:

\footnotetext{
${ }^{144}$ FALIS, Stefan, The aplicability of art. I and art. III of GATT to direct taxes, in HERDIN-WINTER, Judith, HOFBAUER, Ines (org.), The relevance of WTO law for tax matters, Wien, Linde, 2006, p. 39.

${ }^{145}$ SINGH, Chandrajit, Non-Discrimination in Tax Matters in the GATT - National Treatment, in HERDINWINTER, Judith, HOFBAUER, Ines (org.), The relevance of WTO law for tax matters, Wien, Linde, 2006, $\mathrm{p}$ 51.
} 
“Os produtos do território de qualquer Parte Contratante, importados por outra Parte Contratante, não estão sujeitos, direta ou indiretamente, a impostos ou outros tributos internos de qualquer espécie superiores aos que incidem, direta ou indiretamente, sobre produtos nacionais. Além disso nenhuma Parte Contratante aplicará de outro modo, impostos ou outros encargos internos a produtos importados nacionais, contrariamente as principais estabelecidas no parágrafo 1."

Por fim, o artigo III:4 determina que:

"Os produtos de território de uma Parte Contratante que entrem no território de outra Parte Contratante não usufruirão tratamento menos favorável que o concedido a produtos similares de origem nacional, no que diz respeito às leis, regulamento e exigências relacionadas com a venda, oferta para venda, compra, transporte, distribuição e utilização no mercado interno. Os dispositivos deste parágrafo não impedirão a aplicação de tarifas de transporte internas diferenciais, desde que se baseiem exclusivamente na operação econômica dos meios de transporte e não na nacionalidade do produto."

Em outras palavras, bens importados devem ser tratados de forma igual ou não menos favorável que produtos nacionais, de modo a garantir que tributos internos discriminatórios não ajam como substitutos às tarifas de importação ${ }^{146}$. Assim, a essência da regra de tratamento nacional refletida no art. III do GATT é evitar o protecionismo em relação à importação de produtos. Essa regra impede que os estados membros adotem medidas que tenham como efeito outorgar uma vantagem injusta a produtos nacionais em relação a produtos importados, o que violaria o princípio da não discriminação.

Mais importante, a regra de tratamento nacional reconhece que a aplicação de tributos internos de maneira discriminatória impediria o objetivo principal de promover o comércio internacional livre e justo.

146 DALY, Michael, The WTO and direct taxation, 2005, disponível [on line] in http://www.wto.org/english/res_e/booksp_e/discussion_papers9_e.pdf [23-10-2010], p. 4. 
Assim, o artigo III busca criar condições de igualdade no mercado de um Estado Membro de modo a garantir as mesmas condições competitivas aos produtos importados em relação às suas contrapartes nacionais, bem como a evitar que os Estados Membros esvaiam suas obrigações tarifárias assumidas no artigo II por meio de medidas internas discriminatórias ${ }^{147}$.

Note-se que o parágrafo $2^{\circ}$ do artigo III, requer o igual tratamento de "produtos similares $^{148,}$, com a específica determinação de sua aplicação a impostos ou outros tributos internos, direta ou indiretamente. Ademais, os parágrafos 4 a 7 do artigo III referem-se à aplicação não discriminatória de leis, regulamentos e exigências relacionados com a venda, o transporte, a distribuição ou o uso de produtos ${ }^{149}$.

Assim como no caso do Tratamento da Nação Mais Favorecida, a regra de tratamento nacional parece se focar no tratamento de produtos importados em relação aos nacionais. Assim, a sua aplicação ao tributo sobre renda dependerá da possibilidade deste tributo afetar produtos, conforme veremos no tópico II.2.3 infra .

\section{II.1.3. Subsídios}

Na literatura sobre o comércio internacional, os subsídios são tratados como uma barreira não tarifária ao comércio em sentido amplo. McDaniel ${ }^{150}$ mostra que as barreias que se apõem ao livre comércio podem tomar diversas formas, como tarifas, quotas, barreiras técnicas, restrições e subsídios às exportações. Todas estas barreiras teriam uma característica em comum, qual seja: elas estabelecem diferenciação entre

\footnotetext{
${ }^{147}$ SINGH, Chandrajit, Non-Discrimination in Tax Matters in the GATT - National Treatment, in HERDINWINTER, Judith, HOFBAUER, Ines (org.), The relevance of WTO law for tax matters, Wien, Linde, 2006, $\mathrm{p}$ 51.

${ }^{148}$ No texto em português do acordo consta apenas a menção a produtos nacionais; a palavra similares, constante nas versões oficiais em inglês e francês, não consta em português. Todavia, apesar da sua ausência no texto legal brasileiro, trataremos do requisito de similaridade devido à sua presença no texto do acordo em seu idioma oficial.

${ }^{149}$ FALIS, Stefan, The aplicability of art. I and art. III of GATT to direct taxes, in HERDIN-WINTER, Judith, HOFBAUER, Ines (org.), The relevance of WTO law for tax matters, Wien, Linde, 2006, p. 40.

${ }^{150}$ McDANIEL, Paul R., The impact of trade agreements on tax systems, in INTERTAX, v. 30, issue 5, 2002, pp. 166-171 e McDANIEL, Paul R., Trade agreements and income taxation: interactions, conflicts, and resolutions, Boston, 2004, disponível [on line] in http://www.un.org/esa/ffd/aconf198-11.pdf [05.11.2005], p. 166.
} 
produtores de bens e provedores de serviços e capitais estrangeiros e nacionais, implicando tratamento diverso entre eles.

Já apontamos que o GATT distingue as tarifas das restrições não tarifárias ao comércio. Enquanto a redução das tarifas é reconhecida como uma meta a ser alcançada gradualmente, mediante acordos entre as partes contratantes, as barreiras não tarifárias, com as devidas exceções, deveriam ser eliminadas de imediato. Contudo, questiona-se se o GATT possui dispositivos adequados para a efetiva eliminação dos subsídios ${ }^{151}$.

A própria regra de Tratamento Nacional do artigo III traz possível repressão às políticas de subsídios. Conforme apontado, tal regra impede que um Estado membro outorgue tratamento diferenciado aos produtos e serviços nacionais em relação aos importados, sendo possível estender a sua aplicação a subsídios discriminatórios. Todavia, o artigo III.8(b) limita a sua aplicabilidade, uma vez que dispõe que o artigo III não deve impedir o pagamento de subsídios exclusivamente aos produtores domésticos.

$\mathrm{O}$ artigo XVI do GATT, por seu turno, trata os subsídios como uma interferência indesejável na livre circulação de bens, sendo que a "Seção B" dispõe especificamente sobre os subsídios às exportações e a "Seção A", supostamente mais genérica, exige que qualquer país que mantenha um subsídio que aumente as exportações e diminua as importações notifique as partes contratantes do GATT.

Nesse contexto, o ASMC veio expandir a aplicação do artigo XVI do GATT. Incluído na versão de 1994 do GATT, resultado da Rodada do Uruguai, o acordo traz, pela primeira vez, uma definição de subsídio, regulamentando de maneira mais adequada a utilização dos subsídios domésticos, inexistente até então no anterior acordo negociado na Rodada de Tóquio ${ }^{152}$.

Devido à importância desta regulamentação em relação à tributação da renda, analisaremos o ASMC separadamente no Capítulo III infra.

\footnotetext{
151 AVI-YONAH, Reuvem S., The interaction of tax, trade and investment, in Ad Hoc group of experts on international cooperation in tax matters, eleventh meeting, United Nations (documento ST/SG/AC.8/2003/L.4), Geneva, 2003, disponível [on line] in www.un.org [23.10.2005], p. 3.

${ }^{152}$ SCHOUERI, Luís Eduardo, Tributação e cooperação internacional, in RFDT, $\mathrm{n}^{\circ}$ 07, 2004, p. 40; THORSTENSEN, Vera, OMC - Organização Mundial do Comércio: as regras do comercio internacional e a nova rodada de negociações multilaterais, $2^{\text {a }}$ ed., São Paulo, Aduaneiras, 2001, p. 133.
} 
II.2. Aplicação das regras de não discriminação do GATT à tributação da renda

Neste tópico verificaremos se a interpretação das duas regras nas quais se desdobra o princípio da não discriminação no GATT - o Tratamento da Nação Mais Favorecida e o Tratamento Nacional - permite que tais regras alcancem a tributação da renda.

\section{II.2.1. Tributos sobre a renda}

Para fins da aplicação do GATT e, especificamente, dos artigos I e III, não há qualquer definição específica do termo "tributos". O GATT simplesmente menciona tributos internos, encargos e regulamentos, referindo-se à sua aplicação direta ou indireta (artigos I:1 e III:1 e III:2 do GATT). Portanto, não há no texto do GATT qualquer definição de tributo sobre a renda, ou mesmo de tributação direta ${ }^{153}$.

A definição de tributos diretos pode ser encontrada em dois outros acordos no âmbito da OMC, quais sejam, o ASMC e o GATS ${ }^{154}$.

O Anexo I do ASMC, ao trazer lista ilustrativa de subsídios à exportação, dispõe, no item (e), que serão considerados subsídios a isenção, a remissão ou o deferimento total ou parcial, concedidos especificamente em função de exportações, de impostos diretos. A nota de rodapé 58 deste item, por seu turno, esclarece que, para fins do ASMC:

“O termo 'impostos diretos' significa impostos sobre salários, lucros, juros, rendas, direitos de autor e todas as outras formas de ganho, além de impostos sobre a propriedade de bens imóveis;

\footnotetext{
${ }^{153}$ FALIS, Stefan, The aplicability of art. I and art. III of GATT to direct taxes, in HERDIN-WINTER, Judith, HOFBAUER, Ines (org.), The relevance of WTO law for tax matters, Wien, Linde, 2006, p. 41.

${ }^{154}$ LENNARD, Michael, The GATT 1994 and direct taxes: some national treatment and related issues, in LANG, Michael, HERDIN, Judith, HOFBAUER, Ines (org.), WTO and direct taxation, Kluwer Law, 2005, p. 76.
} 
O termo 'direitos de importação' significa tarifas aduaneiras, direitos aduaneiros e outros tributos que não tenham sido enumerados nesta nota e que sejam aplicados à importação;

O termo 'impostos indiretos' significa tributos sobre vendas, consumo, volume de negócio, valor acrescido, franquias, selo, transmissões, estoques $e$ equipamentos, ajustes fiscais na fronteira e todos os impostos além dos que se denominam impostos diretos e direitos de importação;"

Sendo assim, o ASMC diferencia os tributos diretos dos tributos indiretos e também dos tributos sobre a importação. Para fins de aplicação deste acordo, tributos indiretos são aqueles incidentes sobre transações com produtos, faturamento, ou sobre o valor agregado em transações, exceto nos casos de tarifas aduaneiras. Por outro lado, tributos diretos são aqueles que não incidem sobre transações com produtos, mas sobre rendimentos, lucros ou ganhos auferidos por indivíduos ou pessoas jurídicas, bem como impostos incidentes sobre a propriedade de bens imóveis ${ }^{155}$.

O GATS, por seu turno, define tributos diretos no item (o) ${ }^{156}$ do seu artigo XXVIII nos seguintes termos

“'Impostos diretos' abarca todos os impostos sobre a renda total, o capital total, ou sobre elementos da renda ou do capital, inclusive tributos sobre ganhos derivados da alienação de bens, tributos sobre sucessão, herança e doação e os tributos sobre as quantidades totais de salários pagos pelas empresas, assim como os tributos sobre a apreciação de capital"

Similarmente ao ASMC, o GATS define tributos diretos como tributos sobre a renda ou o capital, compreendendo os rendimentos, ganhos e transferências patrimoniais (tais quais heranças e doações).

\footnotetext{
${ }^{155}$ Esta diferenciação é bastante relevante para fins do ASMC, principalmente em função da previsão da nota de rodapé 1 deste acordo, que decorre da nota ao artigo XVI ${ }^{155}$ do GATT e baseia-se na aplicação do princípio do destino a tributos indiretos, conforme veremos (e criticaremos) no tópico III.5 do Capítulo III infra.

${ }^{156}$ A versão em português do GATS, constante da Ata Final que Incorpora os Resultados das Negociações Comerciais Multilaterais da Rodada do Uruguai, anexa ao Decreto $\mathrm{n}^{\circ} 1.355$, de 30 de dezembro de 1994, não possui a alínea "o" no artigo XXVIII. Todavia, esta definição de impostos diretos, que na versão oficial em inglês se encontra no artigo XXVIII(o), consta da nota de rodapé $\mathrm{n}^{\circ} 7$ à alínea (d) do artigo XIV(1) na versão em português do GATS.
} 
Nesses sentido, pode-se afirmar com Schön ${ }^{157}$ que, apesar de não haver no direito da OMC uma definição geral de tributo, é reconhecida a diferença entre tarifas aduaneiras, tributos diretos e tributos indiretos nos termos apontados acima ${ }^{158}$.

O GATT, apesar de não definir o termo "tributos" constante de seus artigos I e III, lida com transações de produtos, sendo que as suas regras buscam evitar a discriminação na tributação de tais transações. O foco, portanto, parece apontar para os tributos indiretos, pois tais tributos, conforme definição acima, incidem sobre transações com produtos.

Com efeito, a aplicação mais comum do Tratamento Nacional e da Nação Mais Favorecida ao âmbito tributário refere-se à tributação incidente sobre produtos, ou indireta $^{159}$. Como exemplo brasileiro de tal aplicação, temos as súmulas 20 do STJ e 575 do STF, que determinam que a mercadoria importada de pais signatário do GATT é isenta do ICM, quando contemplado com esse favor o similar nacional ${ }^{160}$. Obviamente, em casos como estes pode haver discussões quanto à similaridade do produto importado ao nacional, como ocorreu, por exemplo, nos casos de importação brasileira de bacalhau ${ }^{161}$. Todavia, superada a questão da similaridade, a regra de Tratamento Nacional aplica-se aos tributos indiretos. O mesmo raciocínio vale para o Tratamento da Nação Mais Favorecida.

Portanto, em uma primeira análise, poder-se-ia entender que tributos diretos e, consequentemente, a tributação da renda, estão fora do escopo do GATT. A propósito, conforme apontado por Daly ${ }^{162}$, por um bom tempo, a ausência de casos de tributação da renda no âmbito do GATT e da OMC suportava a visão de que a tributação da renda, por não se relacionar suficientemente com produtos, não estaria coberta pelo GATT. No mesmo sentido, Green ${ }^{163}$ afirma que geralmente se entende que as regras dos artigos I e III

\footnotetext{
${ }^{157}$ SCHÖN, Wolfgang, World Trade Organization Law and Tax Law, in BIFD v. 58, 2004, pp. 287.

${ }^{158}$ A diferença entre tributos diretos será analisada no tópico III.5 do Capítulo III infra.

${ }^{159}$ MONROY, Antonio Grimaldo, The relevance of WTO Law for international tax Law, in J. Herdin-Winter, I. Hofbauer (org.), The relevance of WTO law for tax matters, Wien, Linde, 2006, p. 28.

${ }^{160}$ Súmulas estas calcadas em julgados que lidam com a possibilidade do GATT, tratado internacional, restringir a pretensão dos Estados brasileiros relativa a tributos de sua competência. Foge ao nosso escopo, todavia, aprofundarmo-nos nesta questão.

161 Veja Súmula 71 do STJ “O bacalhau importado de pais signatário do GATT é isento do ICM" e precedentes, bem como casos sobre a mesma matéria julgados pelo STF (RE 92.508-2/RJ, DJ 12.06.81, RE 105.606-1/RJ, DJ 13.12.85, dentre outros)

162 DALY, Michael, The WTO and direct taxation, 2005, disponível [on line] in http://www.wto.org/english/res_e/booksp_e/discussion_papers9_e.pdf [23-10-2010], p. 5.

${ }^{163}$ GREEN, Robert A., The interaction of tax and non-tax treaties, in BIFD, v. 56, 2002, n 6, p. 254.
} 
do GATT aplicam-se apenas a tributos indiretos, ou seja, tributos que não incidem sobre a renda ou capital ${ }^{164}$.

Esse ponto de vista é sustentado pelo histórico de negociações do GATT 1947. Durante as discussões da Conferência de Havana sobre a regra de Tratamento Nacional, entendeu-se que, uma vez que a regra se refere especificamente a tributos internos sobre produtos, tributos sobre a renda e tarifas de importação não estariam incluídos no seu escopo $^{165}$.

Ademais, o fato de o GATS prever exclusões específicas de tributos diretos pode ser visto como prova de que o GATT não se aplica a tais tributos, pois tais exclusões não foram necessárias.

Contudo, o julgamento do caso United States - Tax Treatment for "Foreign Sales Corporations" mostrou que há situações em que a tributação da renda é abrangida pelo GATT e não se deve interpretar este acordo limitadamente de modo a excluir tais casos. Conforme o Relatório do Painel ${ }^{166}$ :

“(...) não vemos nenhuma especificação ou limitação no texto do artigo III:4 no que tange ao tipo de vantagem ligada à medida sob análise sob o artigo III:4 do GATT 1994. Assim, nada na letra desta regra especificamente exclui requisitos que condicionem o acesso a medidas de imposto de renda do escopo de aplicação do artigo III (...)"

E conclui:

"O artigo III:4 do GATT 1994 aplica-se a medidas que condicionem o acesso a vantagens de imposto de renda em relação a certos produtos."

\footnotetext{
${ }^{164}$ Ver também THIEL, Servaas van, General report, in LANG, Michael, HERDIN, Judith, HOFBAUER, Ines (org.), WTO and direct taxation, Kluwer Law, 2005, p. 19.

${ }^{165}$ SINGH, Chandrajit, Non-discrimination in tax matters in the GATT - National Tratment, in J. HerdinWinter, I. Hofbauer (org.), The relevance of WTO law for tax matters, Wien, Linde, 2006, p. 64.

${ }^{166}$ Relatório do Painel, United States - Tax Treatment for "Foreign Sales Corporations", Recourse to Article 21.5 of the DSU by the European Communities, WT/DS108/RW, adotado em 29 de janeiro de 2002, modificado pelo Relatório do Órgão de Apelação, WT/DS108/AB/RW, parágrafos 8.142 e 8.143.
} 
O Painel ainda aponta que o GATS forma parte do contexto ${ }^{167}$ do GATT 1994 e chama atenção para o fato de que foi necessário excluir medidas de tributação da renda do tratamento nacional do artigo XVII do GATS. A necessidade de tais exclusões do GATS prova, na visão do Painel, que as regras de tratamento nacional geralmente abrangem os tributos sobre a renda. Sendo assim, conclui o Painel, a regra de tratamento nacional do GATT aplica-se a tributos sobre a renda ${ }^{168}$.

Esta última linha de raciocínio do Painel é bastante frágil. Uma diferença fundamental entre o GATT e o GATS é que o primeiro lida apenas com produtos, enquanto o último lida com serviços e os seus prestadores ${ }^{169}$. Por este motivo, a regra de tratamento nacional do GATS tem, por natureza, aplicação de escopo pessoal (i.e., prestadores de serviços), sendo que tal escopo jamais pode ser estendido à regra de tratamento nacional do GATT, que se foca apenas em produtos. É a inclusão dos prestadores no escopo da regra de tratamento nacional do GATS que torna as exclusões da tributação da renda necessárias (conforme veremos no Capítulo IV infra). Simplesmente estender esse caráter à regra de tratamento nacional do GATT por meio do artigo 31(2) da Convenção de Viena é, em nossa visão, um equívoco. O contexto claramente não é o mesmo, sendo que as particularidades de cada uma das regras de Tratamento Nacional devem ser observadas.

Apesar disso, mesmo que as regras do GATT aplicam-se apenas a medidas tributárias que afetem, direta ou indiretamente, produtos, não devem ser excluídos automaticamente de sua aplicação os tributos sobre a renda.

Se medidas de tributação da renda puderem, em determinadas situações, afetar produtos, os artigos I e III do GATT poderão ser aplicados, conforme veremos a seguir.

\footnotetext{
${ }^{167}$ De acordo com o artigo 31(2) da Convenção de Viena.

${ }^{168}$ SINGH, Chandrajit, Non-discrimination in tax matters in the GATT - National Tratment, in J. HerdinWinter, I. Hofbauer (org.), The relevance of WTO law for tax matters, Wien, Linde, 2006, p. 66. O Painel entendeu, ainda, que as observações na Carta de Havana não afetam a sua conclusão e não impedem a aplicação do artigo III:4 à tributação da renda.

169 DALY, Michael, The WTO and direct taxation, 2005, disponível [on line] in http://www.wto.org/english/res_e/booksp_e/discussion_papers9_e.pdf [23-10-2010], p. 7. Ver Capítulo IV infra.
} 
II.2.2. Dispositivos Relevantes dos Artigos I e III e as suas interpretações

Os dispositivos relevantes para os presentes propósitos são o parágrafo 1 do artigo I, no que tange ao Tratamento da Nação Mais Favorecida, e os parágrafos 1, 2 e 4 do artigo III, no que tange ao Tratamento Nacional.

\section{II.2.2.1. Aplicação do Art. I do GATT}

A leitura do parágrafo 1 do Art. I mostra que "qualquer vantagem, favor, imunidade ou privilégio concedido" em relação ao produto originário de ou destinado a uma parte contratante deve ser "imediata e incondicionalmente estendido ao produto similar, originário do território de cada uma das partes contratantes ou ao mesmo destinado".

Ainda, o parágrafo 1 dispõe expressamente que o Tratamento da Nação Mais favorecida se refere aos "direitos aduaneiros e encargos de toda a natureza que gravem a importação ou a exportação, ou a elas se relacionem". Em princípio, tais medidas não incluem tributos diretos.

Todavia, como já observado, o parágrafo 1 também determina a aplicação do Tratamento da Nação Mais Favorecida aos assuntos incluídos nos parágrafos 2 e 4 do artigo III, que lida com o Tratamento Nacional.

Em virtude desta referência cruzada, todos os assuntos cobertos pelos parágrafos 2 e 4 do artigo III devem ser considerados na aplicação do artigo I. Desse modo, devemos antes verificar a extensão da aplicação do tratamento nacional do artigo III à tributação da renda para, posteriormente, examinar qual o seu impacto quanto à aplicação do Tratamento da Nação Mais Favorecida. 


\section{II.2.2.2. Aplicação do Art. III do GATT}

Singh ${ }^{170}$ ressalta que, nos termos do artigo 31(1) da convenção de Viena sobre o Direto dos Tratados, a interpretação do artigo III deve se fundar no seu próprio texto, sendo que o sentido comum dos seus termos, dentro de seu contexto e à luz do objeto e propósito do GATT, devem fornecer a base para tal interpretação ${ }^{171}$.

Nesse diapasão, o autor aponta que o propósito geral do artigo III é evitar o protecionismo e, enquanto o artigo III:1 delineia os princípios gerais que governam tal objetivo, os parágrafos 2 e 4 articulam condições e requisitos específicos necessários ao seu cumprimento. Em outras palavras, o parágrafo 1 dá o contexto dos outros parágrafos do artigo III, sem, contudo, tirar o significado específico dos termos utilizados nestes parágrafos.

Nesse sentido, o Órgão de Apelações no caso Japan - Alcoholic Beverages ${ }^{172}$, pronunciou-se em seu relatório ${ }^{173}$ :

“Os termos do artigo III devem ser adotados sem eu significado ordinário - no seu contexto e à luz objeto geral e propósito do acordo da OMC. Assim, as palavras efetivamente usadas no Artigo fornecem a base para uma interpretação que deve dar efeito e significado a todos os seus termos. A própria interpretação do artigo é, em primeiro lugar, uma interpretação textual."

Mais adiante, o Órgão de Apelação ainda menciona:

“O amplo e fundamental propósito do Artigo III é evitar o protecionismo na aplicação de tributos e medidas regulatórias internos. Mais especificamente, o propósito do artigo III é garantir que medidas internas não sejam aplicadas a bens importados ou domésticos de modo a permitir a proteção da produção

\footnotetext{
${ }^{170}$ SINGH, Chandrajit, Non-discrimination in tax matters in the GATT - National Tratment, in J. HerdinWinter, I. Hofbauer (org.), The relevance of WTO law for tax matters, Wien, Linde, 2006, p. 52.

${ }^{171}$ Nesse sentido, SCHÖN, Wolfgang, World Trade Organization Law and Tax Law, in BIFD v. 58, 2004, p. 289.

${ }^{172}$ Relatório do Órgão de Apelação em Japan - Alcoholic Beverages, WT/DS8/AB/R, WT/DS10/AB/R, WT/DS11/AB/R, 17-18.

${ }^{173}$ FALIS, Stefan, The aplicability of art. I and art. III of GATT to direct taxes, in HERDIN-WINTER, Judith, HOFBAUER, Ines (org.), The relevance of WTO law for tax matters, Wien, Linde, 2006, p. 42.
} 
doméstica. Para este fim, o Artigo III obriga os Membros da OMC a outorgarem igualdade de condições competitivas para produtos importados em relação aos produtos domésticos."

Seguindo esta abordagem, temos que o parágrafo 1 do Art. III estabelece o Tratamento Nacional e determina que "não devem ser aplicados a produtos importados ou nacionais, de modo a proteger a produção nacional": (i) impostos; (ii) outros tributos internos; (iii) leis; (iv) regulamentos; (v) exigências relacionadas a venda, oferta para venda, compra, transporte, distribuição ou utilização de produtos no mercado interno; e (vi) regulamentações sobre medidas quantitativas internas que exijam a mistura, a transformação ou utilização de produtos, em quantidade e proporções especificadas.

O parágrafo 2, por seu turno, é formado por duas frases. A primeira exige que os produtos do território de qualquer Parte Contratante, importados por outra Parte Contratante, não se sujeitem direta ou indiretamente, a impostos ou outros tributos internos de qualquer espécie superiores aos que incidem, direta ou indiretamente, sobre produtos nacionais similares.

Singh $^{174}$ aponta que, uma vez que seja comprovada, nos termos do artigo III:2, a similaridade dos produtos e a aplicação de impostos ou tributos superiores aos que incidem sobre o produto nacional similar, fica dispensada a comprovação de que a medida "protege a produção nacional”, nos termos do artigo III.1 in fine, pois tal proteção estará subentendida.

A segunda frase do parágrafo 2 determina que "nenhuma parte contratante aplicará de outro modo, impostos ou outros encargos internos a produtos importados ou nacionais, contrariamente aos princípios ${ }^{175}$ estabelecidas no parágrafo 1". Novamente, cumpre notar o papel de "princípio geral" do parágrafo 1 do art. III e a necessidade de tomá-lo em consideração na análise dos outros parágrafos, conforme afirmado pelo Órgão de Apelação no caso Japan - Alcoholic Beverages ${ }^{176}$.

\footnotetext{
${ }^{174}$ SINGH, Chandrajit, Non-discrimination in tax matters in the GATT - National Tratment, in J. HerdinWinter, I. Hofbauer (org.), The relevance of WTO law for tax matters, Wien, Linde, 2006, p. 53.

${ }^{175} \mathrm{Na}$ redação do Decreto Legislativo $\mathrm{n}^{\circ} 43$ de 20 de junho de 1950, publicado no D.O.U. de 21 de junho de 1950, lê-se "contrariamente as principais estabelecidas".

${ }^{176}$ FALIS, Stefan, The aplicability of art. I and art. III of GATT to direct taxes, in HERDIN-WINTER, Judith, HOFBAUER, Ines (org.), The relevance of WTO law for tax matters, Wien, Linde, 2006, p. 43.
} 
A regra da segunda frase do parágrafo 2 deve ser lida em conjunto com a nota ao artigo III:2 no Anexo I do GATT, que determina que um tributo deve ser considerado incompatível com as prescrições da segunda frase do parágrafo 2 , mesmo que esteja de acordo com as regras da primeira frase, nos casos em que haja concorrência entre o produto tributado e um produto diretamente competidor ou que possa ser substituto direto, e que não seja tributado igualmente.

Portanto, o teste da segunda frase do parágrafo 2 dependerá da comprovação da existência de produtos concorrentes ou substitutos diretos (não necessariamente similares), tributados de forma desigual, de modo a proteger a produção nacional ${ }^{177}$.

Sendo assim, a aplicação do artigo III:2 a tributos sobre a renda dependerá da possibilidade de, no caso concreto, tais tributos serem considerados:

(i) para fins da primeira frase do artigo III:2, tributos que incidem, direta ou indiretamente, sobre produtos importados, de maneira mais gravosa do que aquela que incidem sobre produtos nacionais similares; ou

(ii) para fins da segunda frase do artigo III:2, tributos que incidem de forma desigual sobre produtos importados e nacionais concorrentes ou substitutos diretos, de modo a proteger a produção nacional.

O parágrafo 4 do artigo III estabelece a proibição de "tratamento menos favorável" entre "produtos similares"178 importados e nacionais no que tange à aplicação de "leis, regulamentos e exigências" relacionados com a venda, a oferta para venda, a compra, o transporte, a distribuição e a utilização no mercado interno.

A principal diferença entre os parágrafos 2 e 4 do artigo III diz respeito ao tipo de medidas discriminatórias. O artigo III:4 refere-se a leis, regulamentos e exigências enquanto o artigo III:2 a "tributos internos e outros encargos" 179 .

\footnotetext{
${ }^{177}$ Este último requisito (i.e., proteção da indústria nacional) decorre da referência expressa da segunda frase do artigo III:2 ao artigo III:1.

${ }^{178}$ Diferentemente do caso do artigo III:2, a expressão "produtos similares" encontra-se no parágrafo 4 da versão em português do acordo.

${ }^{179}$ FALIS, Stefan, The aplicability of art. I and art. III of GATT to direct taxes, in HERDIN-WINTER, Judith, HOFBAUER, Ines (org.), The relevance of WTO law for tax matters, Wien, Linde, 2006, p. 43.
} 


\section{II.2.3. Aplicação à tributação da renda}

À luz do exposto acima, as seguintes questões específicas devem ser analisadas a fim de verificar a aplicação do GATT à tributação da renda ${ }^{180}$ :

(i) É possível entender que os tributos sobre a renda enquadram-se na expressão “impostos ou outros tributos internos de qualquer espécie que incidem, direta ou indiretamente, sobre produtos" constante do parágrafo 2 do artigo III $^{181}$ ?

(ii) Os tributos sobre a renda podem ser considerados "leis, regulamentos $e$ exigências relacionadas com a venda, oferta para venda, compra, transporte, distribuição ou utilização de produtos" nos termos dos parágrafos 1 e 4 do artigo III?

Se as respostas a estas questões forem afirmativas, poder-se-á concluir que o GATT será aplicável a medidas de tributação direta. É claro que posterior análise da media concreta seria necessária para determinar se:

(i) Para fins da aplicação do artigo III:2, primeira frase, o tributo sobre a renda incidiria de maneira mais gravosa sobre produtos importados do que sobre produtos nacionais similares;

(ii) Para fins da aplicação da segunda frase do artigo III:2, o tributo sobre a renda incidiria de forma desigual sobre produtos importados e nacionais concorrentes ou substitutos diretos, de modo a proteger a produção nacional;

\footnotetext{
${ }^{180}$ FALIS, Stefan, The aplicability of art. I and art. III of GATT to direct taxes, in HERDIN-WINTER, Judith, HOFBAUER, Ines (org.), The relevance of WTO law for tax matters, Wien, Linde, 2006, p. 43.

${ }^{181}$ LENNARD, Michael, The GATT 1994 and direct taxes: some national treatment and related issues, in LANG, Michael, HERDIN, Judith, HOFBAUER, Ines (org.), WTO and direct taxation, Kluwer Law, 2005, p. 78.
} 
(iii) Para fins da aplicação do artigo III:4, o tributo sobre a renda outorgaria tratamento menos favorável entre produtos similares importados e nacionais;

(iv) As referências cruzadas do artigo I:1 aos artigos III:2 e III:3 seriam suficientes para a aplicação do Tratamento da Nação Mais Favorecida às medidas cobertas por estes artigos e, se forem, se haveria "vantagem, favor, imunidade ou privilégio" do tributo sobre a renda não estendido incondicionalmente a todos os "produtos similares" originários do ou destinados ao território de cada uma das outras partes contratantes.

II.2.3.1. Tributos internos e outros encargos internos que incidem, direta ou indiretamente, sobre produtos

No caso Argentina - Measures affecting the export of bovine hides and the import of finished leather ${ }^{182}$ o Painel lidou com a questão da aplicação do parágrafo 2 do artigo III. Para aqueles fins, o Painel conduziu um teste de três passos, a fim de determinar se a medida: (i) configura um tributo ou encargo de qualquer tipo; (ii) é uma medida interna; e (iii) aplica-se direta ou indiretamente a produtos importados ou domésticos ${ }^{183}$.

Iniciando com o primeiro ponto, pode-se concluir que tributos sobre a renda configuram "tributos". Apesar de nenhuma definição ser dada no GATT, já foi apontado no tópico II.2.1 supra que os tributos sobre a renda são considerados tributos pelos acordos sob a OMC.

Quanto ao segundo passo, não há qualquer definição de "interno". É possível entender que o termo "interno" deve ser visto como referente a medidas que não são impostas além das fronteiras. Tal limitação, apesar de parecer razoável para tributos sobre

\footnotetext{
${ }^{182}$ Relatorio do Painel, Argentina - Measures affecting the export of bovine hides and the import of finished leather, WT/DS155/R, 11.139, p. 138.

${ }^{183}$ FALIS, Stefan, The aplicability of art. I and art. III of GATT to direct taxes, in HERDIN-WINTER, Judith, HOFBAUER, Ines (org.), The relevance of WTO law for tax matters, Wien, Linde, 2006, p. 44.
} 
bens e produtos, não faz sentido para a tributação direta, que incide (ou ao menos pode incidir) sobre a renda e sobre fluxos transfronteiriços de rendimentos ${ }^{184}$.

Contudo, não nos parece que o mero fato de um tributo sobre a renda incidir sobre fluxos de renda além-fronteira é suficiente para descaracterizá-lo da aplicação do artigo III em decorrência do termo "internos".

Uma medida de tributação da renda pode ter efeitos no mercado interno de um país e, se for possível concluir que ela incide direta ou indiretamente sobre produtos, de modo mais gravoso sobre os produtos importados em relação ao similares nacionais, não vemos, na letra do artigo III e seu parágrafo 2, razão para excluí-la de sua aplicação.

A nota ao Artigo III, constante do Anexo I do GATT, pode elucidar a interpretação do que se buscou alcançar com a utilização do termo "interno" no artigo III. Tal nota determina que um tributo interno, ou qualquer lei ou regulamento mencionados no parágrafo 1, que se apliquem não só ao produto importado, mas também ao produto nacional similar, e que sejam cobrados ou exigidos, no caso do produto importado, no momento e local da importação, serão considerados um tributo interno e estarão consequentemente sujeitos às disposições do artigo III.

Em outras palavras, segundo a nota esclarece, ainda que um tributo seja cobrado na fronteira em relação aos produtos importados, desde que incida também sobre os produtos nacionais, deve ser considerado tributo interno ${ }^{185}$. O objetivo desta nota é diferenciar os tributos indiretos, sujeitos ao artigo III, dos tributos aduaneiros, sujeitos ao sistema do artigo II, e não ao artigo III $^{186}$. Os tributos aduaneiros são aqueles cobrados apenas nas fronteiras, e não internamente (ou seja, não incidem sobre os produtos

${ }^{184}$ LENNARD, Michael, The GATT 1994 and direct taxes: some national treatment and related issues, in LANG, Michael, HERDIN, Judith, HOFBAUER, Ines (org.), WTO and direct taxation, Kluwer Law, 2005, p. 89.

${ }^{185}$ O GATT Analytical Index esclarece: "The Interpretative Note ad Article III was added at Havana. It makes clear that the mere fact that an internal charge or regulation is collected or enforced in the case of the imported product at the time or point of importation does not prevent it from being an internal tax or other internal charge' and from being subject to the provisions of Article III. During discussions at Havana on the proposal to add the Note, it was stated that 'the proposed additional paragraph was intended to cover cases where internal excise taxes were, for administrative reasons, collected at the time of importation, as well as 'mixing' regulations also enforced at that stage"' WORLD TRADE ORGANIZATION, GATT Analytical Index, disponível [on line] in http://www.wto.org/english/res_e/booksp_e/gatt_ai_e/gatt_ai_e.htm, p. 136.

186 BRITO FILHO, Washington Juarez de, O GATT como norma de direito internacional tributário, in TORRES, Heleno Taveira (org.), Direito Tributário Internacional Aplicado Volume IV, São Paulo, Quartier Latin, 2007. 
nacionais). Já os tributos indiretos, apesar de serem cobrados na fronteira quando da importação de produtos (em decorrência da implementação do princípio do destino, conforme veremos no tópico III.5 do Capítulo III infra), também incidem sobre produtos nacionais e, por isso, devem ser incluídos no artigo III.

Assim, se o objetivo da utilização do termo "internos" é evitar a aplicação do artigo III aos tributos aduaneiros, não há qualquer razão para se entender que os tributos sobre a renda não se enquadram neste conceito de "interno", sujeitando-se ao artigo III.

Finalmente, deve-se verificar se um tributo sobre a renda pode se aplicar direta ou indiretamente a produtos.

No caso Argentina - Measures affecting the export of bovine hides and the import of finished leather ${ }^{187}$, parágrafo 11.159, o Painel entendeu que "tributos sobre a renda, uma vez que são tributos que normalmente não incidem sobre produtos, são geralmente considerados fora do escopo do artigo III:2." Todavia, no mesmo parágrafo, o Painel faz a ressalva de que o mero fato de uma regra ligar-se ao imposto de renda não a impede de relacionar-se com produtos e sujeitar-se à aplicação do artigo III:2.

O mesmo Painel ainda faz duas importantes considerações nos seus parágrafos 11.144 e 11.182 , quais sejam ${ }^{188}$ :

(i) Apesar de os Membros, dentro dos limites do artigo III:2, poderem administrar e cobrar as suas imposições internas do modo que acharem conveniente, quando as medidas de administração do imposto adotam a forma de uma imposição interna e são aplicadas a produtos, tais medidas devem estar em conformidade com o artigo III:2.

(ii) O propósito da primeira frase do artigo III:2 é garantir a "igualdade de condições de competição entre produtos importados e similares nacionais". Assim, a primeira frase do artigo III:2 não lida com tributos

\footnotetext{
${ }^{187}$ Relatório do Painel, Argentina - Measures affecting the export of bovine hides and the import of finished leather, WT/DS155/R.

${ }_{188}$ MOTA, Pedro Infante, O princípio da não discriminação no sistema GATT/OMC, in Revista Fórum de Direito Tributário $\mathrm{n}^{\circ} 24$, 2006e FALIS, Stefan, The aplicability of art. I and art. III of GATT to direct taxes, in HERDIN-WINTER, Judith, HOFBAUER, Ines (org.), The relevance of WTO law for tax matters, Wien, Linde, 2006.
} 
ou encargos como tais, nem com os propósitos visados pelos Membros com a sua adoção, mas com o seu impacto econômico nas oportunidades competitivas de produtos importados e similares nacionais. Consequentemente, o que deve ser comparado é a carga tributária incidente sobre os produtos tributados.

Seguindo essa interpretação, tem-se que o Painel aceitou que medidas tributárias que não se incluem estritamente no conceito de tributos sobre produtos - tais quais medidas de administração tributária - quando afetam produtos devem se dobrar ao artigo III:2. Ademais, o Painel entendeu que na aplicação do artigo III:2 deve-se analisar o impacto tributário incidente sobre os produtos em questão. Poder-se-ia entender que este é o sentido da aplicação indireta aos produtos e, a partir daí, sustentar que os tributos sobre a renda poderiam afetar indiretamente produtos.

$\mathrm{Na}$ ausência de outro critério específico a este respeito, $\operatorname{Singh}^{189}$ sugere que o termo "diretamente" poderia se referir a um tributo sobre o produto, enquanto "indiretamente" cobriria várias outras formas pelas quais tributos poderiam afetar o produto. Poder-se-ia igualmente inferir que "diretamente" refere-se a tributos internos que discriminem de jure entre produtos importados e nacionais, enquanto indiretamente pode se referir a uma discriminação de facto.

Conforme já apontado, a visão tradicional apresentada na Carta de Havana parece negar a possibilidade de uma efetiva conexão dos tributos sobre a renda com produtos. O relatório do Working Party on Border Tax Adjustments ${ }^{190}$ - o qual trata dos ajustes tributários de fronteira, que serão analisados mais detidamente no tópico III.5 do Capítulo III infra - aponta que os ajustes, com base no artigo III do GATT, aplicam-se apenas a tributos incidentes "diretamente" sobre produtos.

Ademais, a interpretação do Órgão de Apelação em Canada - Certain Measures Concerning Periodicals ${ }^{191}$ parece indicar que o termo "diretamente" refere-se à incidência do tributo sobre o produto importado, enquanto "indiretamente" deve ser

\footnotetext{
${ }^{189}$ SINGH, Chandrajit, Non-discrimination in tax matters in the GATT - National Tratment, in J. HerdinWinter, I. Hofbauer (org.), The relevance of WTO law for tax matters, Wien, Linde, 2006, p. 55.

${ }^{190}$ Border Tax Adjustments - Report of the Working Party, adotado em 2 de dezembro de 1970, L/3464.

191 Relatório do Órgão de Apelação em Órgão de Apelação em Canada - Certain Measures Concerning Periodicals, WT/DS31/AB/R, p. 28.
} 
interpretado como representando a incidência do tributo sobre os produtos similares. Se este for o caso, a aplicação do artigo III:2 aos tributos sobre a renda é improvável.

Nesses termos, aceita-se a tradicional divisão entre tributos diretos e indiretos e afirma-se que para efeitos do artigo III:2 apenas os tributos indiretos relacionar-se-iam com produtos.

Por outro lado, não há como negar que a distinção entre tributos indiretos e diretos é bastante frágil, não se sustentando economicamente (ver tópico III.5 do Capítulo III infra). Por isso, parece demasiado simplista o entendimento de que apenas os tributos indiretos podem afetar produtos, seja direta ou indiretamente, e os tributos diretos nunca o farão.

A dificuldade, contudo, encontra-se em determinar se o tributo sobre a renda incide de maneira mais gravosa sobre o produto importado, ou incide desigualmente em relação ao produto nacional.

Nesse sentido, Petritz ${ }^{192}$ aponta que, apesar de se reconhecer que tributos diretos e indiretos são intercambiáveis - uma vez que a incidência econômica de ambos pode recair sobre consumidores -, é impossível determinar exatamente o quanto da incidência dos tributos sobre a renda efetivamente afetaria o preço dos produtos ${ }^{193}$. Se a aplicação do artigo III:2 depende deste teste para que se reste adequadamente comprovado que o imposto de renda incide indiretamente sobre os produtos, provavelmente a aplicação do artigo III:2 ficará prejudicada.

Nesses termos, o enquadramento no artigo III:4 parece ser uma solução mais elegante ao problema, como se verá abaixo. A decisão do Painel no caso Indonesia Certain Measures Affecting the Automobile Industry ${ }^{194}$ parece corroborar este entendimento ao apontar que:

“Quando subsídios a produtores decorrem de isenções ou reduções de tributos indiretos sobre produtos, o artigo III:2 é relevante. Por outro lado, subsídios

\footnotetext{
${ }^{192}$ PETRITZ, Michael, National report Austria, in LANG, Michael, HERDIN, Judith, HOFBAUER, Ines (org.), WTO and direct taxation, Kluwer Law, 2005.

${ }^{193}$ Há que se reconhecer, todavia, que mesmo em relação aos tributos indiretos esta análise não é simples.

${ }^{194}$ WT/DS54/R, WT/DS55/R, WT/DS59/R e WT/DS64/R, parágrafo 14.37, p. 332.
} 
referentes a tributos diretos geralmente não são cobertos pelo artigo III:2, mas podem infringir o artigo III:4 (...)".

Dessa forma, analisaremos a seguir os parâmetros para a aplicação do parágrafo 4 do artigo III aos tributos sobre a renda.

\section{II.2.3.2. Leis, regulamentos e exigências relacionados com produtos}

No que tange ao parágrafo 4, a sua aplicação aos tributos sobre a renda será possível se se puder afirmar que tais tributos são (i) leis, regulamentos ou exigências; e (ii) se relacionem com a venda, oferta para venda, compra, transporte, distribuição e utilização de produtos no mercado interno.

Se a medida de tributação da renda enquadrar-se nesses dois requisitos e, ao mesmo tempo, outorgar tratamento menos favorável entre produtos similares importados e nacionais, ela será vedada pelo artigo III:4.

Os termos "leis, regulamentos ou exigências" não são especificamente definidos pelo GATT. Contudo, pode-se entender que o escopo destes termos é relativamente amplo.

Uma vez que têm função arrecadadora de receitas, na maioria dos países os tributos sobre a renda estão sujeitos a algum procedimento de aprovação do poder legislativo e promulgação, fazendo parte do corpo de leis. No caso brasileiro, convivemos com regra da legalidade estrita tributária, nos termos do artigo 150, I, da Constituição Federal e do artigo 97 do Código Tributário Nacional, pela qual, salvo exceções, somente lei pode instituir, extinguir, majorar, reduzir, definir o fato gerador, alíquota e base de cálculo de tributos. O imposto de renda, parece óbvio, sujeita-se a esta regra.

Consequentemente, medidas de tributação da renda, de uma maneira geral, enquadram-se no termo "leis" constante do artigo III: $4{ }^{195}$.

\footnotetext{
${ }^{195}$ FALIS, Stefan, The aplicability of art. I and art. III of GATT to direct taxes, in HERDIN-WINTER, Judith, HOFBAUER, Ines (org.), The relevance of WTO law for tax matters, Wien, Linde, 2006.
} 
No que tange ao segundo requisito, qual seja, a medida de tributação direta estar relacionada com produtos, é relevante a interpretação adotada pelo Órgão de Apelação no relatório do caso United States - Tax Treatment of Foreign Sales Corporations $^{196}$, no seguinte sentido:

“Observamos que a determinação em que a palavra 'relacionados' aparece, no que diz respeito a todas as leis, regulamentos e exigências 'relacionados' com a venda, oferta para venda, compra, transporte, distribuição e utilização no mercado interno, serve para definir o escopo de aplicação do artigo III:4. Nesta frase, a palavra 'relacionados' opera como um vínculo entre os tipos de ação governamentais identificados (leis, regulamentos e exigências) e transações específicas, atividades e usos relacionados a produtos no mercado (venda interna, oferta para venda, compra, transporte, distribuição ou uso). Portanto, não são quaisquer 'leis, regulamentos e exigências' que são cobertos pelo artigo III:4, mas apenas aqueles 'relacionados' com transações específicas, atividades e usos mencionados naquela regra. Assim, a palavra 'relacionados' auxilia na definição dos tipos de medidas que devem conformar-se à obrigação de não se outorgar tratamento menos favorável a produtos importados similares, estabelecida pelo artigo III:4.”

O Órgão de Apelação ${ }^{197}$, mais adiante, conclui que: “Em decorrência da similar função da idêntica palavra, 'relacionados', [encontrada no artigo III:1 e ] no artigo III:4 do GATT 1994, nós também interpretamos esta palavra, nesta regra, como tendo um 'amplo escopo de aplicação,", 198 .

\footnotetext{
${ }^{196}$ FALIS, Stefan, The aplicability of art. I and art. III of GATT to direct taxes, in HERDIN-WINTER, Judith, HOFBAUER, Ines (org.), The relevance of WTO law for tax matters, Wien, Linde, 2006.

${ }^{197}$ Relatório do Órgão de Apelação, United States - Tax Treatment of Foreign Sales Corporations, para. 210. ${ }^{198}$ Ademais, o Painel valeu-se inclusive de diversos outros julgados (e.g., Relatório do Órgão de Apelação, European Communities - Regime for the Imprtation, Sale and Distribution of Bananas, WT/DS27/AB/R, adotado em 25 de setembro de 1997, parágrafo 220; Relatório do Painel, Canada - Certain Measures Affecting the Automotive Industry, WT/DS139,142/AB/R, adotado em 19 de junho de 2000, parágrafo 10.80) para demonstrar que o termo "relacionados" no contexto do artigo III deve receber um significado mais amplo, inferindo-se, assim, que tributos sobre a renda estariam incluídos nas medidas que afetam a venda interna de produtos. SINGH, Chandrajit, Non-discrimination in tax matters in the GATT - National Tratment, in J. Herdin-Winter, I. Hofbauer (org.), The relevance of WTO law for tax matters, Wien, Linde, 2006, pp. 66-67.
} 
O Relatório do Painel no caso United States - Tax Treatment of Foreign Sales Corporations ${ }^{199}$ ressaltou que a relação com os produtos, no caso, não decorria do próprio imposto de renda, mas das condições cujo preenchimento era necessário para o gozo do benefício de imposto de renda ${ }^{200}$.

Uma vez que tais condições se relacionavam a produtos, o Painel concluiu: "Não vemos especificação ou limitação no texto do artigo III:4 acerca do tipo de vantagem ligada à medida examinada sob o artigo III:4 do GATT 1994. Assim, nada na letra do dispositivo especificamente exclui requisitos que condicionem o acesso a medidas de imposto de renda do escopo de aplicação do artigo III, que lida com o 'Tratamento Nacional no Tocante à Tributação e Regulamentação Internas ,’.

Assim, cremos que não há como excluir medidas de tributação direta da aplicação do artigo III do GATT, em virtude de seu parágrafo 4.

Isso não significa, contudo, que todas as medidas de tributação da renda estariam incluídas nesse escopo.

A primeira linha de corte a ser traçada é a efetiva relação entre produtos e a medida de tributação da renda. A segunda é a determinação de que tal medida efetivamente outorga tratamento menos favorável entre produtos similares importados e nacionais.

Note-se que, diferentemente do artigo III:2 (principalmente a primeira frase), o artigo III:4 não se refere a incidência mais gravosa, mas apenas a tratamento menos favorável. Assim haveria que se comprovar a referida discriminação, de jure ou de facto, pela regra de tributação da renda em questão.

\footnotetext{
${ }^{199}$ Relatório do Painel, United States - Foreign Sales Corporations, Recourse to Article 21.5 of the DSU by the European Communities, WT/DS108/RW.

${ }^{200}$ Veja tópico III.4.2 do Capítulo III infra.
} 


\section{II.2.3.3. Extensão para o artigo I}

Vista a possibilidade de aplicação do artigo III:4 e, de certa forma, do artigo III:2 à tributação da renda, cumpre verificar a possibilidade de aplicação do artigo I, que traz a regra do Tratamento da Nação Mais Favorecida do GATT.

Em primeiro lugar, vale relembrar que o artigo I:1 determina que: qualquer favor, imunidade ou privilégio,concedido por um Membro em relação a produto originário de ou destinado a qualquer outro país, será estendido ao produto similar originário do território de cada um dos Membros, ou a ele destinado. No que importa para a nossa análise, os referidos favores, imunidades ou privilégios referem-se:

a direitos aduaneiros e encargos de toda natureza que gravem a importação ou exportação, ou a elas se relacionem;

(ii) ao conjunto de regulamentos ou formalidades estabelecidos em conexão com a importação e a exportação;

(iii) aos assuntos incluídos nos parágrafos 2 e 4 do artigo III do GATT, que lida com o Tratamento Nacional.

Parece sensato afirmar que medidas de tributação da renda não se qualificam nos itens (i) e (ii) $\operatorname{acima}^{201}$.

Todavia, verificamos nos tópicos acima que os parágrafos 2 e 4 do artigo III podem ser aplicados à tributação da renda. Sendo assim, em nossa visão, a referência cruzada feita pelo artigo I a estes parágrafos faz com que o Tratamento da Nação Mais Favorecida do GATT também se aplique a medidas de tributação da renda ${ }^{202}$.

\footnotetext{
201 Nesse sentido, Michael Schyle aponta que "encargos de toda natureza" relacionam-se com "direitos aduaneiros" e a qualificação "gravem a importação ou a exportação" deve restringir a interpretação desta expressão às tarifas aduaneiras em geral. Da mesma forma, "regulamentos ou formalidades" devem ser conexos à exportação e importação, razão pela qual as medidas de tributação da renda não se incluiriam neste rol. SCHYLE, Michael, Most favoured nation treatment in tax matters in the GATT, in J. Herdin-Winter, I. Hofbauer (org.), The relevance of WTO law for tax matters, Wien, Linde, 2006, p. 86.

${ }^{202}$ PETRITZ, Michael, National report Austria, in LANG, Michael, HERDIN, Judith, HOFBAUER, Ines (org.), WTO and direct taxation, Kluwer Law, 2005, p. 156. Em sentido contrário, Michael Schyle defende a que a referência cruzada aos artigos III:2 e III:4 não faz com que o artigo I aplique-se a tributos diretos. Todavia, o autor defende o seu ponto de vista sustentando a não aplicação dos próprios artigos III:2 e III:4 aos tributos diretos. Conforme já verificado acima, há fundamentos suficientes - inclusive na própria jurisprudência da OMC - para se sustentar a aplicação dos parágrafos 2 e 4 do artigo III a determinadas
} 
Nesses termos, uma medida de tributação da renda que não discrimine entre produtos importados e nacionais, mas que discrimine entre produtos importados de diferentes países pode estar sujeita à aplicação do artigo $\mathrm{I}^{203}$.

Por exemplo, o Estado Membro A pode prever regras de depreciação acelerada para produtos importados do País B, a qual não se aplica aos produtos similares importados do Estado Membro C nem aos produtos similares produzidos no Estado-membro A. Nesse caso, a depreciação acelerada dada aos produtos do Estado B deveria ser estendida a produtos similares advindos do Estado C (e aos produtos similares advindos de todos os outros Estados Membros).

Esta situação também pode ocorrer no caso em que o Estado A não produz produtos similares àqueles importados dos Estados B e C. Neste caso, o Tratamento Nacional não poderia ser aplicado por ausência de similaridade com o produto nacional, mas o Tratamento da Nação Mais Favorecida poderia se aplicar para estender aos produtos do Estado C o benefício dado pelo Estado A aos produtos do Estado B.

\section{II.3. Acordo TRIMS}

Apesar de ser um acordo separado, acreditamos fazer mais sentido tratar da relação entre o Acordo Sobre Medidas de Investimento Relacionadas ao Comércio TRIMS (“Acordo TRIMS") neste tópico, pois as medidas por ele abrangidas relacionam-se com os artigos III e XI do GATT.

medidas relacionadas a tributos diretos. Dessa maneira, entendemos que o argumento de Schyle não é suficiente para impedir a aplicação do artigo I à tributação da renda. SCHYLE, Michael, Most favoured nation treatment in tax matters in the GATT, in J. Herdin-Winter, I. Hofbauer (org.), The relevance of WTO law for tax matters, Wien, Linde, 2006, pp. 91 e ss)

${ }^{203}$ Nesse sentido, Schön afirma que o princípio da Nação Mais Favorecida aplica-se a todos os tipos de regras; ele não se limita aos impostos aduaneiros, devendo ser aplicado também a tributos indiretos e diretos na medida em que tais tributos fizerem distinções entre produtos baseadas no critério do país de origem. SCHÖN, Wolfgang, World Trade Organization Law and Tax Law, in BIFD v. 58, 2004. 


\section{II.3.1. Visão geral}

A regulamentação dos investimentos internacionais constitui tema controvertido, que tradicionalmente tem dividido países desenvolvidos e em desenvolvimento.

Note-se que as disposições da Carta de Havana que, em larga medida, contribuíram para o fracasso da criação da Organização Internacional do Comércio na década de 40 , referem-se a investimentos ${ }^{204}$.

Mais recentemente, na Rodada Doha da OMC, que teve início em 2001, o assunto, introduzido na pauta da Conferência Ministerial de Cingapura, em 1996, foi objeto de intensas negociações sem que se tenha chegado ainda a um consenso. O tema nem sequer foi incluído na pauta de negociações da Conferência Ministerial de Cancun realizada dois anos mais tarde em $2003^{205}$.

Essa dificuldade em se firmar acordos sobre regras de investimentos tem levado, ao longo dos anos, à conclusão de acordos bilaterais que procuram regular relações em matéria de investimentos, com a finalidade de aumentar seu fluxo, estipulando regras de proteção ao investimento estrangeiro ${ }^{206}$. Ao final de 2006, 2.573 acordos bilaterais sobre investimentos (“BITs") tinham sido firmados ${ }^{207}$.

É sabido que os países se valem de incentivos fiscais e não fiscais para atrair investimentos. Tais, medidas, apesar de distorcerem a alocação internacional do capital, não se incluem nas medidas abrangidas pelo Acordo TRIMS.

\footnotetext{
${ }^{204}$ CELLI JUNIOR, Umberto, Os acordos de serviços (GATS) e de investimentos (TRIMs) na OMC: espaço para políticas de desenvolvimento (2006) disponível [on-line] in http://www.usp.br/prolam/downloads/gats.pdf [15.01.2011]. O autor aponta ainda que a tentativa de alguns países desenvolvidos de negociar um Acordo Multilateral de Investimentos ("MAI") no âmbito da Organização para a Cooperação e o Desenvolvimento Econômico ("OCDE”) constitui outro exemplo importante. Dentre os temas que, a partir de 1995, têm sido negociados na OCDE com vistas à celebração de um MAI, destacam-se: (i) definição de investimento e alcance geográfico de aplicação do MAI; (ii) tratamento da nação mais favorecida, tratamento nacional e transparência, exceções gerais, derrogações temporárias e reservas; (iii) requisitos de desempenho e incentivos aos investimentos, tecnologia, pesquisa e questões de desenvolvimento; e (iv) resolução de controvérsias.

${ }^{205}$ Idem, ibidem.

${ }^{206}$ Idem, ibidem.

${ }^{207}$ SAUVANT, Karl P., SACHS, Lisa E. The Effect of Treaties on Foreign Direct Investment Flows in Karl P. Sauvant, Lisa E. Sachs (orgs.), The Effects of Treaties on Foreign Direct Investment: Bilateral Investment Treaties, Double Taxation Treaties and Investment Flows, Oxford, Oxford University Press, 2009.
} 
Todavia, além dos incentivos para a atração de capital e investimento estrangeiro direto, os países por vezes também impõem determinadas condições a estes benefícios, de modo a garantir que os investimentos realizados coadunem-se com determinadas prioridades nacionais ${ }^{208}$ de desenvolvimento ${ }^{209}$ ou industriais ${ }^{210}$.

Se as condições ao gozo destes benefícios determinarem a utilização de insumos nacionais, ao invés de importados, limitarem o acesso a produtos importados, ou exigirem que determinada performance de exportação de produtos seja atingida, podem distorcer o comércio internacional de produtos, agindo como substitutas a barreiras tarifárias ou a subsídios ${ }^{211}$. Algumas destas condições (chamadas Trims) são vedadas pelo Acordo TRIMS.

Nesses termos, o Acordo TRIMS acabou não tendo a abrangência originalmente pretendida pelos países desenvolvidos ${ }^{212}$. No seu estado atual, ele não é um acordo que efetivamente versa sobre a proteção ou liberalização de fluxos de investimento e capitais, mas um acordo que versa sobre o reflexo do GATT em regras dos estados membros acerca de investimentos ${ }^{213}$.

Nesses termos, o artigo 1 do Acordo TRIMS determina que ele se aplica "somente a medidas de investimento relacionadas ao comércio de bens (referidas no Acordo como 'TRIMS')". O artigo 2 esclarece este âmbito de aplicação, vedando a utilização, por parte dos membros da OMC, de medidas de investimentos inconsistentes com os dispositivos do Artigo III (tratamento nacional) e do Artigo XI (restrições quantitativas) do GATT. Vejamos:

208 DALY, Michael, The WTO and direct taxation, 2005, disponível [on line] in http://www.wto.org/english/res_e/booksp_e/discussion_papers9_e.pdf [23-10-2010], p. 6.

${ }^{209}$ CELLI JUNIOR, Umberto, Os acordos de serviços (GATS) e de investimentos (TRIMs) na OMC: espaço para políticas de desenvolvimento (2006) disponível [on-line] in http://www.usp.br/prolam/downloads/gats.pdf [15.01.2011].

${ }^{210}$ NASSER, Rabih Ali, Política Industrial e os Acordos da OMC: Subsídios, TRIMs e Investimentos, São Paulo, 2003, disponível [on line] http://www.direitogv.com.br/AppData/Publication/PoliticaIndustrialAcordosOMCRabihNasser.pdf, [01.02.2011].

${ }^{211}$ Ver itens 1 e 2 da lista do Anexo ao Acordo TRIMS.

${ }^{212}$ CELLI JUNIOR, Umberto, op. cit.

${ }^{213}$ DALY, Michael, op. cit, p. 6. 
1. Sem prejuizo de outros direitos e obrigações sob o GATT 1994, nenhum Membro aplicará qualquer TRIM incompatível com as disposições do Artigo III ou do Artigo XI do GATT 1994.

2. Uma lista ilustrativa de TRIMs incompativeis com a obrigação e tratamento nacional prevista no parágrafo 4 do Artigo III do GATT 1994 e com a obrigação de eliminação geral de restrições quantitativas prevista no parágrafo 1 do Artigo XI do GATT 1994 se encontra no Anexo ao presente Acordo.

Assim, as regras inconsistentes com o Acordo TRIMS são aquelas regras de investimentos que discriminam produtos nacionais e importados em desacordo com os artigos III e XI do GATT ${ }^{214}$.

Apesar de o acordo não definir medidas de investimentos relacionadas ao comércio, ele fornece no seu Anexo uma lista ilustrativa de medidas que, nos termos do parágrafo $2^{\circ}$ do artigo 2, são incompatíveis com a obrigação de Tratamento Nacional do parágrafo $4^{\circ}$ do artigo III do GATT e com a obrigação de eliminação geral das restrições quantitativas prevista no parágrafo $1^{\circ}$ do artigo XI do GATT ${ }^{215}$. Vejamos:

1. As TRIMs incompatíveis com a obrigação de tratamento nacional prevista no parágrafo 4 do Artigo III do GATT 1994 incluem as mandatórias ou aquelas aplicáveis sob a lei nacional ou decisões administrativas, ou cujo cumprimento é necessário para se obter uma vantagem e que determinam:

a) que uma empresa adquira ou utilize produtos de origem nacional ou de qualquer fonte nacional especificadas em termos de produtos individuais, em termos de volume ou valor de produtos, ou em termos de uma proporção do volume ou valor de sua produção local;

214 DALY, Michael, The WTO and direct taxation, 2005, disponível [on line] in http://www.wto.org/english/res_e/booksp_e/discussion_papers9_e.pdf [23-10-2010], p. 6.

${ }^{215}$ CELLI JUNIOR, Umberto, Os acordos de serviços (GATS) e de investimentos (TRIMs) na OMC: espaço para políticas de desenvolvimento (2006) disponível [on-line] in http://www.usp.br/prolam/downloads/gats.pdf [15.01.2011]. DALY, Michael, op. cit., p. 6. 
b) que a aquisição ou utilização de produtos importados por uma empresa limite-se a um montante relacionado ao volume ou valor de sua produção local.

2. As TRIMs incompatíveis com a obrigação de eliminação geral das restrições quantitativas prevista no parágrafo 1 do Artigo XI do GATT 1994 incluem as mandatórias, aquelas aplicáveis sob a lei nacional ou mediante decisões administrativas, ou aquelas cujo cumprimento é necessário para se obter uma vantagem e que restringem:

a) a importação por uma empresa de produtos utilizados ou relacionados com sua produção local em geral ou a um montante relacionado ao volume ou valor de sua produção local destinada à exportação;

b) a importação por uma empresa de produtos utilizados eu sua produção local ou relacionados com a mesma mediante a restrição de seu acesso a divisas estrangeiras em um montante equivalente à entrada de divisas estrangeiras atribuíveis a essa empresa;

c) a exportação ou venda para exportação de produtos por uma empresa, restrição especificada em termos de produtos individuais, em termos de volume ou valor de produtos, ou em termos de uma proporção do volume ou valor de sua produção local.

Vale notar que as Trims proibidas incluem não apenas medidas obrigatórias, mas também aquelas condições cujo cumprimento é necessário para a obtenção de uma vantagem $^{216}$. Apesar de o termo "vantagem" utilizado nos itens 1 e 2 do Anexo não ser definido no Acordo TRIMS, deve-se entender que ele abrange todo tipo de vantagem, incluindo benefícios fiscais ${ }^{217}$.

Aponte-se, ainda, que as vedações do acordo não incluem medidas que vinculem a fruição de um benefício a determinada performance de exportação. Tais

216 DALY, Michael, The WTO and direct taxation, 2005, disponível [on line] in http://www.wto.org/english/res_e/booksp_e/discussion_papers9_e.pdf [23-10-2010], p. 6.

$\frac{217}{21}$ Esta interpretação fica clara no relatório do Painel no caso Indonesia - Certain Measures Affecting the Automobile Industry, analisado mais adiante. 
medidas, por seu turno, podem ser vedadas pelo ASMC, conforme será analisado no Capítulo III infra.

Finalmente, o artigo 3 do Acordo TRIMS determina que todas as exceções amparadas pelo GATT aplicam-se, conforme apropriado, às disposições do acordo. Os artigos 5 e 6 estabelecem a obrigação de notificação ao Conselho para o Comércio de Bens da OMC, no período de 90 dias a partir de $1^{\circ}$ de janeiro de 1995 , acerca das Trims em aplicação e incompatíveis com as disposições do acordo. Essas Trims, de acordo com o disposto no parágrafo 2 do artigo 5, deveriam ser eliminadas no prazo de dois anos a partir de $1^{\circ}$ de janeiro de 1995 (no caso dos países desenvolvidos), cinco anos (no caso dos países em desenvolvimento) e sete anos (no caso dos países de menor desenvolvimento relativo) $)^{218}$.

\section{II.3.2. Aplicação à tributação da renda}

Cumpre verificar, neste ponto, se determinadas medidas relativas à tributação da renda poderiam ser vedadas pelo Acordo TRIMS.

Seguindo a proposta de análise constante do Relatório do Painel em Indonesia - Certain Measures Affecting the Automobile Industry, é necessário determinar se tais medidas são: (i) "medidas de investimento"; e (ii) "relacionadas ao comércio". Em seguida, é necessário verificar se as medidas são incompatíveis com os artigos III ou XI do GATT.

No que tange à caracterização de regras de tributação da renda como medidas de investimento, vale notar que o Painel, em Indonesia - Certain Measures Affecting the Automobile Industry ${ }^{219}$, entendeu que a linguagem do Acordo TRIMS não limita a sua aplicação a medidas relacionadas a investimento estrangeiro.

\footnotetext{
${ }^{218}$ NASSER, Rabih Ali, Política Industrial e os Acordos da OMC: Subsídios, TRIMs e Investimentos, São Paulo, 2003, disponível [on $\quad$ line] http://www.direitogv.com.br/AppData/Publication/PoliticaIndustrialAcordosOMCRabihNasser.pdf, [01.02.2011], p. 19.

${ }^{219}$ WT/DS54/R, WT/DS55/R, WT/DS59/R e WT/DS64/R, 14.73 e 14.81, pp. 339 e 342.
} 
Assim, não haveria qualquer razão para que medidas relativas a tributos internos e subsídios não fossem consideradas medidas de investimento sujeitas às regras do acordo. Benefícios fiscais e subsídios seriam, na visão do Painel, um tipo de vantagem que pode ser atrelada a exigências de conteúdo nacional, um dos principais focos do Acordo TRIMS. Este acordo não lida com os benefícios ou subsídios como tais, mas com os requisitos para o seu usufruto.

O Painel ainda conclui que o fato de uma medida não ser caracterizada como medida de investimento pelo Estado Membro não significa que ela não será caracterizada como tal para efeitos de aplicação do Acordo TRIMS.

Ainda, conforme já apontado, não são apenas as regras que obrigam conteúdo nacional, limitem as importações etc., que se enquadram nas vedações do Acordo TRIMS. Regras que condicionam vantagens, dentre as quais benefícios fiscais, à utilização de conteúdo local, limitação de importação etc., também são consideradas Trims vedadas pelo acordo.

Nesse sentido, benefícios de tributos sobre a renda podem enquadrar-se no conceito de medidas de investimento para efeitos de aplicação do Acordo TRIMS. Resta verificar se tais vantagens de tributos sobre a renda relacionam-se ao comércio.

Sobre essa relação, o Painel, em Indonesia - Certain Measures Affecting the Automobile Industry, foi categórico ao apontar que medidas que condicionam a fruição de tais benefícios ao uso de conteúdo local são necessariamente relacionadas ao comércio, pois tal condicionamento favorece o uso de produtos nacionais e, portanto, afeta o comércio. Nesse aspecto, parece que medidas que operem quaisquer das restrições apontadas nos itens do Anexo ao Acordo TRIMS seriam relacionadas ao comércio.

De uma maneira geral, a relação com o comércio deve ser testada face ao escopo material dos artigos III e XI do GATT. Ou seja, é necessário verificar se a medida discrimina produtos importados em relação aos nacionais ou impõe alguma restrição quantitativa. Em nosso entendimento, uma condição ao acesso de um benefício de imposto de renda pode concretizar ambos. 
O foco da análise sob o Acordo TRIMS não é a vantagem em si, mas a condição para que tal vantagem seja fruída. Nesses termos, um benefício físcal de imposto de renda pode ser condicionado a qualquer das medidas vedadas pela lista constante do Anexo ao acordo.

É perfeitamente concebível que um país possa criar uma isenção de imposto de renda das pessoas jurídicas condicionada, por exemplo, (i) à utilização de insumos nacionais em sua produção; (ii) à limitação da aquisição de insumos importados em relação ao volume de sua produção local; ou (iii) à limitação da importação de insumos em relação à sua produção local destinada à exportação.

Essas condições limitariam a utilização de uma vantagem - a isenção de imposto de renda - de maneira incompatível com o artigo III:4 ou com o artigo XI:1 do GATT e, nesses termos, seriam vedadas pelo artigo II do Acordo TRIMS, bem como pelos itens da lista constante de seu Anexo.

\section{II.4. Possíveis casos}

A análise feita neste tópico mostra que a tributação da renda não é excluída da aplicação da regra de Tratamento Nacional constante do artigo III do GATT, nem da regra de Tratamento da Nação Mais Favorecida, constante do artigo I. Ademais, o Acordo TRIMS também pode ser aplicável a medidas de tributação da renda.

Todavia, tal aplicação dependerá da comprovação de que a regra de tributação da renda efetivamente se relaciona com produtos e discrimina produtos importados entre eles (para fins da aplicação do Tratamento da Nação Mais Favorecida) ou em relação a produtos nacionais (para fins de aplicação do Tratamento Nacional e, de certa forma, do Acordo TRIMS).

A tributação da renda, que incide sobre a renda auferida por pessoas físicas ou jurídicas, tipicamente não realiza este tipo de discriminação de produtos ${ }^{220}$.

${ }^{220}$ Nesse sentido, Michael Lennard afirma que o GATT aplica-se sim aos tributos diretos, mas não frequentemente e não no alcance normal dos tributos diretos, pois tais tributos geralmente não são considerados 'internos' ou não se relacionam suficientemente com produtos para que haja tal aplicação. 
Conduto, em casos excepcionais, determinadas vantagens ou desvantagens referentes à tributação da renda podem ser vinculadas à utilização, pelo contribuinte, de determinados produtos em detrimento de outros.

Essas regras podem ser vistas como efetivas subvenções tributárias, voltadas a induzir os contribuintes a adquirirem um tipo de produto em detrimento de outro.

Nestes casos, pode haver um vínculo suficiente entre a tributação da renda e os produtos que justifique a aplicação do GATT ou do Acordo TRIMS se a discriminação for contrária a estes acordos. Vejamos, a seguir, casos concretos em esta situação pode ocorrer.

\section{II.4.1. Regras de tributação da renda relacionadas a produtos}

Os casos mais comuns de aplicação do Tratamento Nacional do GATT às regras de tributação da renda são aqueles em que a legislação somente permite a dedutibilidade do custo de determinados insumos, ou a depreciação de bens de capital, se tais insumos ou bens forem nacionais.

Tais medidas seriam contrárias ao artigo III do GATT, bem como ao artigo 1 do Acordo TRIMS e ao item 1 do anexo deste acordo $^{221}$. Tais medidas também seriam consideradas subsídios proibidos nos termos do artigo 3 do ASMC, conforme veremos no tópico III.2.3.1 do Capítulo III infra.

Exemplos dessas medidas na legislação brasileira são regras de depreciação acelerada aplicáveis para empresas que tiverem executado Programas de Desenvolvimento Tecnológico Industrial - PDTI até 3 de junho de 1993, ou forem titulares de Programas Especiais de Exportação (BEFIEX) aprovados até esta data ${ }^{222}$.

LENNARD, Michael, The GATT 1994 and direct taxes: some national treatment and related issues, in LANG, Michael, HERDIN, Judith, HOFBAUER, Ines (org.), WTO and direct taxation, Kluwer Law, 2005

${ }^{221}$ THIEL, Servaas van, General report, in LANG, Michael, HERDIN, Judith, HOFBAUER, Ines (org.), WTO and direct taxation, Kluwer Law, 2005, p. 21.

${ }^{222}$ Os programas aprovados a partir de 1993 passaram a ter o seu regime de depreciação regido pela Lei $\mathrm{n}^{\circ}$ 8.661/93, que não restringia o benefício aos bens de produção nacional. Ainda, como a Lei $\mathrm{n}^{\circ}$ 8.661/93 foi revogada pela Lei $n^{\circ} 11.196 / 05$, não há mais base legal para a aplicação do benefício da depreciação incentivada para programas aprovados após 1993 (pode-se defender, todavia, que como a Lei no 8.661/93 não 
Máquinas, equipamentos, aparelhos e instrumentos novos utilizados nas atividades de produção (BEFIEX) e desenvolvimento tecnológico industrial no País (PDTI e BEFIEX) destas empresas poderão ser depreciados, para fins de apuração do lucro real, a uma taxa igual a duas vezes a taxa usualmente admitida, desde que tais bens sejam de produção nacional. Ou seja, se estas empresas adquirirem bens importados, não poderão se aproveitar da depreciação acelerada.

Questão interessante surge se uma regra de conteúdo local deste tipo não for vinculada especificamente ao uso de produtos nacionais, mas a uma porcentagem de valor agregado local no produto final, independente da utilização de produtos nacionais ${ }^{223}$.

Neste caso, deve-se notar, em primeiro lugar, que a exigência de valor agregado local deve permitir que produtos possam ser incluídos no cômputo de tal valor agregado. Se não permitir, o GATT e o Acordo TRIMS não se aplicarão ${ }^{224}$.

Se a regra incluir produtos em seu cômputo, mas também possibilitar que outros itens - como, por exemplo, mão de obra - constituam o valor agregado local, não há uma resposta clara quanto ao enquadramento no GATT e no Acordo TRIMS (e no artigo 3:1(b) do ASMC, conforme veremos no Capítulo III infra).

Zhou ${ }^{225}$ sugere que seria necessário verificar o percentual de valor agregado local exigido. Se ele não for tão alto e puder ser atingido sem a necessidade da utilização de produtos nacionais, será possível defender que não há o vínculo ao conteúdo local. Todavia, se o percentual for alto de maneira tal que seja necessária a utilização de produtos nacionais, então haverá o vínculo.

Essa questão surgiu na discussão do caso FSC (ver tópico III.4.2 do Capítulo III infra). Todavia, uma vez que o Painel já tinha considerado o regime FSC um subsídio à

revogou efetivamente o Decreto $2.433 / 88$, este voltaria a se aplicar, pois não se trataria de caso de repristinação).

${ }^{223}$ ZHOU, Zibin, The definition of subsidies under the SCM agreement, in J. Herdin-Winter, I. Hofbauer, The relevance of WTO law for tax matters, Wien, Linde, 2006, p. 320. O autor refere-se à regra de conteúdo local do ASMC, mas o mesmo raciocínio se aplica neste caso.

${ }^{224}$ E também o ASMC, como veremos no Capítulo III infra.

${ }^{225}$ ZHOU, Zibin, The definition of subsidies under the SCM agreement, in J. Herdin-Winter, I. Hofbauer, The relevance of WTO law for tax matters, Wien, Linde, 2006, p. 320. 
exportação à luz do artigo 3(1)(a) do ASMC, entendeu que a questão da regra de conteúdo nacional não precisaria ser analisada ${ }^{226}$.

No tópico II.4.2.1 abaixo, analisaremos se as regras de preços de transferência podem ser consideradas exigências de conteúdo local. A questão é bastante interessante à luz da teoria das subvenções fiscais, pois regras de preços de transferência são adotadas pela maioria dos países $^{227}$, podendo-se defender que fazem parte da estrutura "parâmetro" de tais países.

\section{II.4.2. Preços de transferência}

Como mencionado, as regras de preços de transferência podem trazer algumas dificuldades quando analisadas à luz das obrigações de Tratamento Nacional ${ }^{228}$ e Nação Mais Favorecida do GATT.

Tais regras exigem que, em determinadas situações, a dedutibilidade dos custos de produtos importados por empresas brasileiras seja ajustada pelos métodos de preços de transferência.

Tais regras, pelo fato de serem aplicadas quando da importação de produtos, podem cair no escopo do GATT e do TRIMS em virtude dos motivos explicados nos tópicos anteriores deste capítulo.

\section{II.4.2.1. Tratamento Nacional e TRIMS}

O primeiro problema que pode surgir em relação aos ajustes de preços de transferência refere-se à aplicação do Tratamento Nacional conforme o artigo III:4 do

${ }^{226}$ United States - Tax Treatment for "Foreign Sales Corporations, WT/DS108/R, parágrafos 7.131 e 7.132, p. 284.

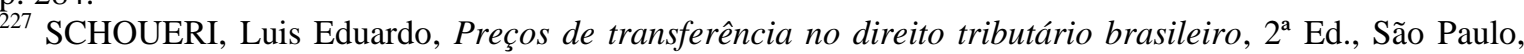
Dialética, 2006, P. 30.

${ }^{228}$ HINTSANEN, Lari, National report Finland, in LANG, Michael, HERDIN, Judith, HOFBAUER, Ines (org.), WTO and direct taxation, Kluwer Law, 2005, p. 264. THIEL, Servaas van, General report, in LANG, Michael, HERDIN, Judith, HOFBAUER, Ines (org.), WTO and direct taxation, Kluwer Law, 2005, p. 21. 
GATT e da regra de conteúdo local constante do Acordo TRIMS, especificamente no artigo 2:1 e no item 1(a) do Anexo do acordo.

A possível incompatibilidade destes dispositivos com os ajustes de preços de transferência decorre do fato de que tais ajustes seriam aplicados apenas quando uma empresa adquire produtos do exterior, não se aplicando para as aquisições de produtos no mercado local.

Tomemos as regras brasileiras como exemplo. O artigo 18 da Lei $\mathrm{n}^{\circ}$ 9.430/96 prevê que os custos, despesas e encargos relativos a bens constantes dos documentos de importação ou de aquisição, nas operações efetuadas com pessoa vinculada no exterior, com pessoa residente em jurisdição de tributação favorecida ou em regime fiscal privilegiado $^{229}$, somente serão dedutíveis na determinação do lucro real até o valor que não exceda ao preço determinado pelos métodos arrolados em seus incisos.

Os ajustes de preços de transferência apenas se aplicam aos custos, despesas e encargos relativos a bens importados, por empresa brasileira, de residentes ou domiciliados no exterior. Tais ajustes não se aplicam nos casos de aquisição de bens no mercado brasileiro. Sendo assim, poder-se-ia sustentar que haveria uma vantagem (i.e. o não ajuste dos custos pelas regras de preços de transferência) outorgada às empresas brasileiras que adquirirem produtos no mercado brasileiro, em oposição à aquisição de produtos importados.

Tal vantagem, por seu turno, poderia ser vista como uma exigência de conteúdo local, contrária ao artigo III:4 do GATT e ao artigo 2:1 do Acordo TRIMS.

No entanto, no nosso ponto de vista este entendimento não deve prosperar. Apesar de o chamado "aims-and-effect test" $" 230$ ter sido rejeitado pela jurisprudência da

\footnotetext{
${ }^{229}$ Pessoas vinculadas são as pessoas residentes ou domiciliadas no exterior que se enquadram em algum dos incisos do artigo 23 da Lei n 9.430/96. Pessoas residentes em jurisdição de tributação favorecida são aquelas residentes em países definidos no artigo 24 desta mesma lei. Pessoas que se valem de regimes privilegiados são aquelas que residem em países que possuem regimes definidos no artigo 24-A da Lei no 9.430/96 e se valem da aplicação destes regimes. Os conceitos de país de tributação favorecida e de regime fiscal privilegiado (doravante denominados simplesmente "paraísos fiscais") serão explorados no tópico II.4.2.2 infra, onde constaremos que diversos membros da OMC podem se enquadrar nestes conceitos.

${ }^{230}$ Teste que sustentava que o propósito de uma medida deveria ser considerado na análise de sua conformação com o GATT.
} 
$\mathrm{OMC}^{231}$, que entende que a aplicabilidade do artigo III não depende do propósito de política fiscal de uma medida tributária, cremos que a análise da finalidade das regras de preço de transferência é fundamental para verificarmos se elas são discriminatórias sob o artigo III do GATT e o Acordo TRIMS.

Para tanto, devemos compreender que transações entre partes ligadas, que fazem parte de um mesmo grupo econômico, não necessariamente serão expressas em valores de mercado.

Enquanto partes independentes buscam maximizar o seu lucro individual em uma transação - sendo que, dos interesses contrapostos de tais partes, surge o "preço de mercado" -, partes ligadas agem de acordo com outro racional. Esta contraposição de interesses não existe necessariamente em uma transação entre partes ligadas, o que faz com que o preço de uma transação entre tais partes seja um "preço de grupo", que não refletirá o efetivo preço de mercado do bem, serviço ou direito transacionado.

As regras de preços de transferência prestam-se a ajustar, para fins de apuração da base de cálculo dos tributos incidentes sobre a renda, os preços praticados entre partes ligadas para que eles passem a refletir preços de mercado. Trata-se da aplicação do princípio arm's length.

A finalidade primordial desse ajuste é garantir que a renda efetiva da empresa, apurada em valores de mercado, seja tributada. Este objetivo remonta a uma questão de igualdade $^{232}$, pois, uma vez que os valores de grupo são manipuláveis, somente os valores de mercado são indicativos da renda de um contribuinte.

Os contribuintes somente poderão ser tratados de forma igual pelo imposto de renda se todos eles demonstrarem a sua renda em termos de valores de mercado para fins da apuração deste imposto. Se alguns deles puderem demonstrá-la em valores de grupo, enquanto outros, que efetivamente transacionam no mercado, apresentarem-na em valores

${ }^{231}$ Relatório do Órgão de Apelação em Japan - Taxes on Alcoholic Beverages, WT/DS8/AB/R; WT/DS10/AB/R; WT/DS11/AB/R; p. 16. Relatório do Painel em Argentina - Measures affecting the export of bovine hides and the import of finished leather, WT/DS155/R, parágrafo 11.144. Relatório do Órgão de Apelação em European Communities - Regime for the Importation, Sale and Distribution of Bananas, WT/DS27/AB/R, parágrafos 216 e 241.

${ }^{232}$ SCHOUERI, Luis Eduardo, Preços de transferência no direito tributário brasileiro, $2^{\mathrm{a}}$ Ed., São Paulo, Dialética, 2006, pp. 10-15. 
de mercado, o imposto não poderá ser aplicado de forma igual. Por isso, os ajustes de preços de transferência são necessários para a adequada aplicação do imposto de renda.

Ademais, a legislação de preços de transferência busca evitar que grupos econômicos deliberadamente manipulem os preços das transações de modo a alocar a renda tributável do grupo em uma jurisdição de baixa tributação, escapando à tributação nos outros países em que o grupo tem atividades e efetivamente aufere renda.

Assim, a aplicação do princípio arm 's length pode ser vista como um meio de garantir que um país efetivamente tribute a renda que, em termos de mercado, foi auferida por seus residentes. Pode ser vista também, como meio de evitar abusos por parte de grupos econômicos multinacionais que, se pudessem manipular livremente, para fins de apuração do imposto de renda, o preço das transações entre suas empresas em várias jurisdições, escapariam à tributação da renda, ou ao menos reduziriam drasticamente a carga tributária do grupo ${ }^{233}$.

As transações entre partes relacionadas em um mesmo país não precisam destes ajustes, ainda que os preços praticados não necessariamente reflitam valores de mercado. Sendo ambas as partes da transação tributadas no mesmo país, a redução da base de cálculo do imposto de renda de uma parte geralmente representará igual aumento da base da outra parte. Dito de outro modo, a despesa dedutível de uma empresa é receita tributável de outra e, no final das contas, a carga tributária final do grupo tende a ser a mesma. Assim, a renda tributável efetiva de um grupo no mesmo país não se altera em decorrência de transações entre partes ligadas, pois o grupo continua sendo tributado em "valores de mercado".

É claro que isso não é sempre verdade, considerando que lucros do grupo podem ser alocados em empresas com perdas acumuladas, ou as partes da transação podem ser tributadas por sistemáticas diversas (lucro real e lucro presumido, por exemplo) que implicam cargas tributárias finais diversas para cada uma delas (podendo o lucro ser alocado, por manipulação de preços, à parte sob a sistemática mais benéfica). Todavia, a legislação possui meios específicos para lidar com estes casos, meios estes diversosdas regras de preços de transferência.

${ }^{233}$ AVI-YONAH, Reuven S., International Tax as International Law: An Analysis of the International Tax Regime, New York, Cambridge University Press, 2007, p. 102. 
A peculiaridade das regras de preços de transferência que não pode ser ignorada para os nossos propósitos é que, tendo em vista as suas finalidades mencionadas acima, elas não se aplicam apenas às importações, mas também às exportações entre partes ligadas.

Com efeito, a demonstração da renda de uma empresa brasileira deixará de refletir valores de mercado em duas situações, quais sejam:

(i) nos casos em que esta empresa importar produtos de partes ligadas no exterior e deduzir os custos, despesas e encargos relativos a tais produtos levando em conta o preço praticado entre partes do grupo, e não o preço de mercado; e

(ii) nos casos em que esta empresa exportar produtos para partes ligas no exterior e escriturar receitas de venda destes produtos pelos preços praticado entre partes do grupo, e não pelo preço de mercado.

Sendo assim, as regras de preço de transferência buscam:

(i) nas importações de parte ligada, estabelecer um limite máximo para a os custos, despesas e encargos que serão deduzidos da base de cálculo do imposto da empresa brasileira, de modo a evitar que o preço de grupo excedente ao preço de mercado seja deduzido da base de cálculo do imposto de renda;

(ii) nas exportações para parte ligada, estabelecer um limite mínimo para a receita que comporá a base de cálculo do imposto de renda da empresa brasileira, de modo a evitar que a parcela do preço de grupo inferior ao preço de mercado deixe de ser escriturado e escape da base do imposto.

Essa análise mostra claramente que a finalidade das regras de preços de transferência, longe de se relacionar à proteção dos produtos nacionais em relação aos importados, é garantir que o imposto de renda da empresa brasileira seja apurado levando em conta o valor de mercado das transações com partes ligadas no exterior, sejam elas importações ou exportações. 
Todavia, considerando a rejeição do aims-and-effect test pela jurisprudência da OMC, é necessário que nos amparemos em algo além da finalidade para demonstrar que uma medida não é discriminatória à luz do artigo III do GATT.

Em nossa visão, o que se deve extrair da análise da finalidade das regras de preços de transferência é que os produtos importados de partes ligadas e os produtos nacionais adquiridos no mercado interno não estão em situação comparável. Eles não são similares para fins de aplicação do artigo III do GATT.

No que tange aos preços de transferência, os produtos importados por empresas brasileiras de partes ligadas no exterior ou de paraísos fiscais somente estão em situação comparável com os produtos nacionais exportados por empresas brasileiras a partes ligadas no exterior ou a paraísos fiscais. Estes são os produtos nacionais e importados similares para fins de aplicação do artigo III.

Se entendermos, neste caso específico, que os produtos importados somente são comparáveis com produtos nacionais exportados, constataremos que ambos estão sujeitos aos ajustes de preços de transferência.

Assim, segundo este raciocínio, as regras de preços de transferência somente serão discriminatórias à luz do artigo III do GATT se aplicadas de maneira assimétrica às importações e as exportações, favorecendo as últimas. Exemplo óbvio de situação de tal aplicação assimétrica seria o caso de um país cuja legislação previsse ajustes apenas nas importações, e não nas exportações.

No entanto, há exemplos menos óbvios. Mesmo que a lei preveja ajustes tanto nas importações quanto nas exportações, se as regras aplicáveis às importações resultarem, de direito ou de fato, em ajustes mais gravosos do que nas exportações, pode haver discriminação à luz do artigo III do GATT. Analisaremos mais adiante algumas medidas da legislação brasileira que podem ser consideradas discriminatórias nesse aspecto.

Um argumento subsidiário para defender que a aplicação das regras de preços de transferência não fere o GATT é que tais regras enquadrar-se-iam nas exceções do artigo XX do GATT. 
Enfatize-se que tal argumento é apenas subsidiário em relação ao argumento da similaridade que apresentamos acima. Em nossa visão, o artigo $\mathrm{XX}$ sequer deve ser aplicado devido ao fato de as regras de preço de transferência, se aplicadas simetricamente, não serem contrárias ao artigo III do GATT, pois não discriminam produtos nacionais e importados similares. Se não há medida discriminatória, o recurso ao artigo XX não é necessário. A aplicação deste artigo pode ser necessária, por outro lado, para coadunar algumas particularidades das regras de preços de transferência brasileiras com o artigo I do GATT, como veremos no tópico II.4.2.2 abaixo.

A alínea (d) do artigo XX excepciona da aplicação do GATT as medidas necessárias a assegurar a aplicação de leis e regulamentos que não sejam incompatíveis com as disposições do acordo, bem como as medidas próprias a impedir as práticas de natureza a induzir ao erro.

Seria possível defender que os ajustes de preços de transferência se enquadram nesta exceção.

Em primeiro lugar, tais ajustes prestam-se a assegurar que a renda dos contribuintes seja demonstrada em valores de mercado e não de grupo econômico, garantindo que o imposto de renda possa ser aplicado adequadamente. Este objetivo não parece ser incompatível com o GATT.

Em segundo lugar, parece possível afirmar que os ajustes de preços de transferência são medidas voltadas a impedir "práticas de natureza a induzir ao erro" devido à sua finalidade de coibir a elisão fiscal.

Com efeito, tais regras impedem que contribuintes manipulem preços de transações com partes ligadas e, desta forma, reduzam a sua base de cálculo do imposto de renda. A manipulação de preços entre partes ligadas poderia ser vista como uma prática voltada a induzir (o fisco) ao erro. Portanto, as medidas voltadas a coibi-las seriam justificadas nos termos da alínea (d) do artigo $\mathrm{XX}^{234}$.

\footnotetext{
234 Jakob Gross aponta, todavia, que não há reconhecimento pela OMC de medidas para garantir a conformidade com o sistema tributário como justificativas. GROSS, Jakob, OECD defensive measures against harmful tax competition legality under WTO, in INTERTAX, v. 31, issue 11, 2003, p. 393.
} 
Note-se que o controle dos preços de transações entre partes ligadas para a adequada aplicação de tributos não é estranho ao GATT, que reconhece em seu artigo VII e no Acordo sobre a Implementação do Artigo VII do Acordo Geral sobre Tarifas e Comércio 1994 (Acordo sobre Valoração Aduaneira) a necessidade de ajuste de preços, para fins de incidência dos tributos aduaneiros, em determinadas transações que não refletem o preço de mercado dos bens transacionados ${ }^{235}$.

Assim, parece-nos que os ajustes de preço de transferência poderiam encontrar justificativa na alínea (d) do artigo XX. No entanto, deve-se salientar que o artigo XX deve ser aplicado de acordo com o seu caput.

No tópico IV.2.2.2 do Capítulo IV infra, faremos análise mais detalhada acerca da aplicação do caput artigo XX. Por ora, cumpre adiantar que uma medida que contraria as regras do GATT, ainda que justificada por alguma das alíneas do artigo XX, deve se coadunar com a ressalva do caput, que exige que a medida (i) não diferencie países em iguais condições, além do necessário para atingir o fim visado; (ii) não tenha efeito protecionista, ou seja, não diferencie produtos nacionais e estrangeiros além do necessário para atingir o fim visado; e (iii) seja proporcional, i.e., adequada, necessária e razoável em relação ao fim visado.

Nesses termos, ainda que as regras de preços de transferência possam se enquadrar no artigo $\mathrm{XX}(\mathrm{d})$, elas não devem ser aplicadas de modo a realizar discriminações desnecessárias.

Em nossa visão, isso leva à mesma conclusão a que chegamos anteriormente sob o argumento da similaridade: as regras de preços de transferência devem ser aplicadas simetricamente às operações de importação e exportação. Se não o forem, contrariarão o caput do artigo XX, pois a discriminação é desnecessária para atingir o objetivo previsto na alínea $(d)$.

Sendo assim, se determinado país adotar em sua legislação ajustes de preço de transferência mais gravosos para as importações do para as exportações, estará realizando

\footnotetext{
${ }^{235}$ Há, inclusive, quem defenda uma correlação jurídica na aplicação da valoração aduaneira e dos ajustes de preços de transferência. HILÚ NETO, Miguel, $O$ elo jurídico entre a valoração aduaneira e os preços de transferência, in FERNANDES, Edison Carlos, Preços de transferência, São Paulo, Quartier Latin, 2007, p. 65.
} 
discriminação que, além de ser contrária ao artigo III do GATT, não pode ser justificada sob o artigo XX(d), à luz da ressalva prevista no caput deste artigo.

Considerando estas conclusões acerca da relação entre o GATT e as regras de preços de transferência, cumpre-nos verificar se a legislação brasileira possui medidas que podem ser consideradas discriminatórias.

Para tanto, dois aspectos de nossa legislação devem ser considerados. O primeiro deles refere-se aos métodos previstos para os ajustes de importação no artigo 18 da Lei nº 9.430/96, que não são simétricos aos métodos aplicáveis aos ajustes nas exportações, previstos no artigo 19 desta lei. O segundo refere-se aos safe harbors (“salvaguardas") previstos na Lei no 9.430/96 e na Instrução Normativa $n^{\circ}$ 243/02, que se aplicam apenas aos ajustes em exportações.

Os métodos de preço de revenda menos lucro ${ }^{236}$ previstos nos artigos 18 , II e 19, II e III, da Lei n ${ }^{\circ}$ 9.430/96 aplicam-se da seguinte maneira:

(i) $\mathrm{Na}$ importação:

a. Método PRL20: quando o bem é revendido no Brasil sem ser aplicado na produção nacional, o preço parâmetro deve ser apurado subtraindo-se do valor de revenda os descontos incondicionais, impostos e contribuições sobre vendas, comissões e corretagens e a margem de $20 \%$ do valor de revenda.

b. Método PRL60: quando o bem é aplicado na produção a questão torna-se mais complexa. Sem adentrar em muitos detalhes, vale apontar que o preço de revenda também deve ser reduzido dos descontos, tributos e comissões, bem como da margem de $60 \%$ sobre este preço e do valor agregado no país. A Instrução Normativa $\mathrm{n}^{\mathrm{o}} 243 / 02$, de legalidade duvidosa ${ }^{237}$, aplica fórmula que, em última análise, faz com que o preço parâmetro seja igual a $40 \%$ do valor de revenda do bem (reduzido dos descontos, tributos e

${ }^{236}$ SCHOUERI, Luis Eduardo, Preços de transferência no direito tributário brasileiro, $2^{\mathrm{a}}$ Ed., São Paulo, Dialética, 2006, pp. 133-188.

${ }^{237}$ Idem, ibidem, pp. 133-188. 
comissões) multiplicado pelo valor do bem importado e dividido pelo custo total do bem produzido.

(ii) $\mathrm{Na}$ exportação:

a. Método PVA, pelo qual o preço parâmetro é calculado pela média aritmética dos preços de venda de bens, idênticos ou similares, praticados no mercado atacadista do país de destino, em condições de pagamento semelhantes, diminuídos dos tributos incluídos no preço, cobrados no referido país, e de margem de lucro de $15 \%$ sobre o preço de venda no atacado.

b. Método PVV, pelo qual o preço parâmetro é calculado pela média aritmética dos preços de venda de bens, idênticos ou similares, praticados no mercado varejista do país de destino, em condições de pagamento semelhantes, diminuídos dos tributos incluídos no preço, cobrados no referido país, e de margem de lucro de 30\% sobre o preço de venda no varejo.

Podemos verificar que os métodos de preço de revenda menos lucro abarcam diferentes situações na importação e na exportação. Na importação há a previsão de método para bens aplicados na produção, enquanto na exportação não há. Para bens importados e revendidos sem serem aplicados na produção, o método PRL20 determina que o preço de revenda seja diminuído da margem de 20\%. Para bens exportados, o método PVA determina que a margem de $15 \%$ seja reduzida do valor de venda de bens idênticos ou similares no mercado atacadista do país de destino, enquanto o método PVV determina que a margem de $30 \%$ seja reduzida do valor de venda de bens idênticos ou similares no mercado varejista do país de destino.

Apesar de ser difícil determinar abstratamente se há tratamento mais favorecido das exportações na aplicação dos métodos de preço de revenda, tal tratamento pode ocorrer em casos concretos, principalmente naqueles em que a aplicação do método PVA for possível. Este tipo de assimetria pode ser considerado discriminatório à luz do artigo III do GATT. 
Os métodos do custo mais lucro ${ }^{238}$, previstos nos artigos 18 , III, e 19, IV, da Lei $n^{\circ}$ 9.430/96, aplicam-se da seguinte maneira:

(i) $\mathrm{Na}$ importação, o método $\mathrm{CPL}$ pede que o preço parâmetro seja calculado pelo custo médio de produção de bens, idênticos ou similares, no país onde tiverem sido originariamente produzidos, acrescido dos impostos e taxas cobrados pelo referido país na exportação e de margem de lucro de $20 \%$, calculada sobre o custo apurado.

(ii) $\mathrm{Na}$ exportação, o método CAP pede que o preço parâmetro seja calculado pela média aritmética dos custos de aquisição ou de produção dos bens exportados, acrescidos dos impostos e contribuições cobrados no Brasil e de margem de lucro de $15 \%$ sobre a soma dos custos mais impostos e contribuições.

No que tange a estes métodos, parece-nos que o CAP, aplicável às exportações, tende a ser mais favorável do que o CPL, aplicado às importações, devido ao fato de que este exige a aplicação da margem de lucro de $20 \%$ sobre os custos, enquanto aquele exige apenas a aplicação da margem de $15 \%$. Esta diferença de tratamento pode, em nossa visão, ser considerada discriminatória à luz do artigo III do GATT.

Por fim, a legislação brasileira prevê algumas hipóteses de safe harbors ${ }^{239}$, as quais dispensam o contribuinte de comprovar a adequação de seus preços de transferência nas operações de exportação para pessoas vinculadas, desde que estes preços encontrem-se em determinadas faixas.

O primeiro caso de safe harbor que merece menção é aquele previsto no próprio caput do artigo 19 da Lei $\mathrm{n}^{\circ}$ 9.430/96. Segundo esta salvaguarda, fica o contribuinte dispensado de comprovar a adequação dos preços de transferência quando o preço médio (líquido de frete e seguro suportados pela exportadora) praticado nas exportações efetuadas a pessoas vinculadas seja igual ou superior a $90 \%$ do preço médio ${ }^{240}$

\footnotetext{
${ }^{238}$ SCHOUERI, Luis Eduardo, Preços de transferência no direito tributário brasileiro, $2^{\mathrm{a}}$ Ed., São Paulo, Dialética, 2006, pp. 189-201.

${ }^{239}$ Idem, ibidem, pp. 233-259.

${ }^{240}$ Líquido dos descontos incondicionais concedidos, do frete, do seguro, do ICMS, da COFINS, PIS/PASEP e outros encargos cobrados pelo poder público e suportados pela vendedora.
} 
praticado na venda dos mesmos bens no mercado brasileiro, durante o mesmo período e em condições de pagamento semelhantes.

O segundo safe harbor consta do artigo 36 da IN 243/02 e tem amparo no artigo 45 da Lei $n^{\circ}$ 10.833/03. Ele permite a comprovação da adequação dos preços praticados em exportações com base nos documentos relacionados com a própria operação, quando a receita líquida de exportações da pessoa jurídica, no ano calendário, não exceder a $5 \%$ do total da receita líquida no mesmo período $^{241}$.

O terceiro safe harbor que merece ser mencionado é aquele previsto no artigo 35 da IN 243/02, que também tem amparo no artigo 45 da Lei no 10.833/03. Ele assegura que, caso o lucro líquido resultante das receitas de exportações feitas a partes relacionadas seja igual ou superior a $5 \%$ do total dessas receitas, restará dispensada a comprovação de adequação aos métodos dos preços de transferência ${ }^{242}$.

Por fim, aponte-se a salvaguarda de simplificação veiculada pelo artigo 38 da IN 243/02, que admite margens de divergência de até 5\%, entre o parâmetro encontrado a partir dos métodos propostos na lei e os preços constantes dos documentos de importação e exportação. Nessa hipótese, a comprovação será considerada satisfatória segundo os próprios valores constantes nos documentos de importação ou exportação.

A legislação brasileira não prevê qualquer safe harbor específico para a aplicação dos ajustes de preços de transferência nas importações. Entendemos que esta assimetria, decorrente da aplicação exclusiva dos safe harbors mencionados acima às exportações, pode ser considerada discriminatória à luz do artigo III do GATT.

\footnotetext{
${ }^{241}$ Esse safe harbor não se aplica no caso de vendas efetuadas para empresas vinculadas domiciliadas em países com tributação favorecida ou cuja legislação interna oponha sigilo, em consonância com o artigo 37, I, da IN 243/02 e com o $\S 1^{\circ}$ do artigo 45 da Lei $n^{\circ} 10.833 / 03$.

242 Esse safe harbor também não se aplica no caso de vendas efetuadas para empresas vinculadas domiciliadas em países com tributação favorecida ou cuja legislação interna oponha sigilo, por força do mesmo artigo 37, I, da IN 243/02 e do $§ 1^{\circ}$ do artigo 45 da Lei $n^{\circ} 10.833 / 03$.
} 


\section{II.4.2.2. Nação Mais Favorecida}

O segundo problema em relação à adequação das regras de preços de transferência ao GATT refere-se à aplicação do Tratamento da Nação Mais Favorecida.

Regras de preços de transferência podem ser aplicadas de forma diferenciada dependendo do país de onde advêm os produtos importados. O Brasil é um bom exemplo de país que diferencia a aplicabilidade de suas regras de preços de transferência de acordo com o país de origem dos produtos importados.

Com efeito, a regra brasileira impõe que os ajustes de preços de transferência sejam aplicados:

(i) às importações de pessoas vinculadas no exterior, de acordo com os critérios do artigo 23 da Lei $n^{\circ}$ 9.430/96; e

(ii) às importações de pessoas residentes em jurisdição de tributação favorecida, ou em regime fiscal privilegiado ("paraísos fiscais") ${ }^{243}$, independentemente da existência de vínculo entre importador e exportador, conforme determinam os artigos 24 e 24-A da Lei $n^{\circ}$ 9.430/96.

Ademais, pessoas físicas brasileiras que realizem transações com residentes em paraísos fiscais também estão obrigadas a realizar ajustes de preços de transferência na forma prevista no $\$ 2^{\circ}$ do artigo 24. Este é o único caso em que ajustes de preços de transferência aplicam-se a pessoas físicas brasileiras.

Com isso, vemos que os produtos advindos de paraísos fiscais receberão tratamento menos favorável do que os produtos advindos de países que não se enquadram neste conceito. Isso ocorre porque a dedutibilidade, pelas empresas brasileiras, dos custos, despesas e encargos relacionados a produtos importados de paraísos fiscais sempre estará sujeita aos ajustes de preços de transferência, enquanto a dedutibilidade dos custos,

\footnotetext{
${ }^{243}$ SCHOUERI, Luis Eduardo, Preços de transferência no direito tributário brasileiro, $2^{\mathrm{a}}$ Ed., São Paulo,
} Dialética, 2006, p. 63-66. 
despesas e encargos dos produtos advindos de países não enquadrados neste conceito nem sempre se submeterá a tais ajustes.

O conceito de paraísos fiscais, para fins de aplicação das regras de preços de transferência, é dado pelos artigos 24 e 24-A da Lei no 9.430/96.

O caput do artigo 24 refere-se aos países ou dependências que não tributam a renda, ou tributam-na a alíquota máxima inferior a vinte por cento. $\mathrm{O} \S 4^{\circ}$ adiciona que também será considerado país ou dependência com tributação favorecida aquele cuja legislação não permita o acesso a informações relativas à composição societária de pessoas jurídicas, à sua titularidade ou à identificação do beneficiário efetivo de rendimentos atribuídos a não residentes.

$\mathrm{O}$ artigo 24-A, por seu turno, define como regime fiscal privilegiado aquele que:

(i) não tribute a renda ou a tribute à alíquota máxima inferior a vinte por cento;

(ii) conceda vantagem de natureza fiscal a pessoa física ou jurídica não residente:

a. sem exigência de realização de atividade econômica substantiva no país ou dependência

b. condicionada ao não exercício de atividade econômica substantiva no país ou dependência

(iii) não tribute, ou o faça em alíquota máxima inferior a $20 \%$ (vinte por cento), os rendimentos auferidos fora de seu território

(iv) não permita o acesso a informações relativas à composição societária, titularidade de bens ou direitos ou às operações econômicas realizadas

Assim, um país que geralmente tribute a renda a alíquota superior a vinte por cento e não oponha sigilo pode possuir regimes específicos que se enquadram no artigo 24- 
A. Se o residente no Brasil realizar uma transação com exportador residente em tal país e o exportador beneficiar-se destes regimes, as regras de preços de transferência para paraísos fiscais aplicar-se-ão.

A Instrução Normativa $n^{\circ} 1.037$, de 4 de junho de 2010, traz uma "lista negra" dos países que são considerados pela Receita Federal como países de tributação favorecida e dos regimes fiscais privilegiados.

Dos sessenta e cinco países listados como jurisdições de tributação favorecida, vinte e cinco são membros da OMC. São eles: Antígua e Barbuda; Antilhas Holandesas; Bahrein; Barbados; Belize; Brunei; Chipre; Cingapura; República da Costa Rica; Djibouti;Dominica; Emirados Árabes Unidos; Hong Kong; Liechtenstein; Macau; Maldivas; Ilhas Maurício; Panamá; São Vicente e Granadinas; Ilhas Solomon; St. Kitts e Nevis; Suazilândia; Suíça ${ }^{244}$; Sultanato de Omã; e Tonga.

A instrução normativa lista nove regimes fiscais privilegiados nos seguintes países: Luxemburgo; Uruguai; Dinamarca; Reino dos Países Baixos ${ }^{245}$; Islândia; Hungria; Estados Unidos da América; Espanha ${ }^{246}$; e Malta. Todos estes países são membros da OMC.

O fato de o Brasil exigir ajustes de preços de transferência em importações destes países mesmo quando inexiste vínculo entre importador e exportador, bem como os ajustes a pessoas físicas somente nas importações destes países, parece contrariar o artigo I do $\operatorname{GATT}^{247 ; 248}$.

\footnotetext{
${ }^{244}$ Os efeitos da inclusão da Suíça na lista foram suspensos pelo Ato Declaratório Executivo RFB nº 11, de 24 de junho de 2010.

${ }^{245}$ O Ato Declaratório Executivo RFB no 10, de 24 de junho de 2010 suspendeu os efeitos da aplicação da inclusão dos Países Baixos na lista de regimes privilegiados.

${ }^{246}$ O Ato Declaratório Executivo RFB no 22, de 30 de novembro de 2010 suspendeu os efeitos da aplicação da inclusão da Espanha na lista de regimes fiscais privilegiados.

${ }^{247}$ FALZON, Franco, Most-favored-nation treatment in the GATS and its effect on direct taxation, in J. Herdin-Winter, I. Hofbauer, The relevance of WTO law for tax matters, Wien, Linde, 2006, p. 127. O autor analisa as regras brasileiras à luz do tratamento da nação mais favorecida do GATS, mas parece-nos que a mesma conclusão aplica-se ao GATT.

${ }^{248}$ Daniel Rybnik aponta que a Argentina possui regras semelhantes às brasileiras, que preveem a aplicação do controle de preços de transferência em transações com paraísos fiscais, independentemente do vínculo. RYBNIK, Daniel, Preços de transferência y entre partes independientes em la Argentina, in FERNANDES, Edison Carlos, Preços de transferência, São Paulo, Quartier Latin, 2007, p 91
} 
Sendo assim, a menos que haja uma justificativa para este tratamento diferenciado nos termos do artigo XX do GATT, os países Membros da OMC que se qualificam como paraísos fiscais na legislação brasileira poderiam exigir que o Brasil outorgasse a eles o mesmo tratamento que outorga aos Membros não qualificados como paraíso fiscal.

Conforme se apontou no tópico anterior, regras de preço de transferência, devido à sua finalidade de coibir a elisão fiscal, podem ser consideradas "práticas de natureza a induzir ao erro" nos termos da alínea (d) do artigo XX do GATT.

No entanto, o mero enquadramento nesta alínea não é suficiente para justificar a aplicação discriminatória destas regras entre os membros da $\mathrm{OMC}^{249}$. Seria necessário encontrar uma justificativa para o tratamento diferenciado dos paraísos fiscais em relação aos demais membros da OMC. Ou seja, a aplicação das regras de preços de transferência nas importações de paraísos fiscais mesmo na ausência de vínculo entre as partes deve ser amparada na finalidade de coibir a elisão fiscal.

Deve-se apontar, em primeiro lugar, que o fato de estas jurisdições tributarem a renda a alíquotas nominais muito baixas (seja por previsão geral em sua legislação, ou pela existência de regimes especiais) torna-as boas candidatas a serem utilizadas por empresas multinacionais que buscam reduzir a sua carga global de imposto de renda por meio da manipulação de preços de transferência.

Com efeito, se um grupo multinacional constituir uma subsidiária em paraíso fiscal e realizarem todas as suas transações internacionais intragrupo utilizando tal subsidiária como intermediária, há grandes possibilidades de se alocar toda renda do grupo nesta subsidiária, por meio da manipulação de preços. Como a renda da subsidiária será tributada a alíquotas baixas, a tributação da renda efetiva do grupo seria reduzida.

Imaginemos o seguinte exemplo: uma controladora em um país que tributa a renda à alíquota de $40 \%$ que exporta bens para a sua "Subsidiária $\mathrm{A}$ ", situada em outro país que tributa a renda a $40 \%$. O bem é vendido pela Subsidiária A no mercado interno do país

${ }^{249}$ Cf. United States - Prohibition of Imports of Tuna and Tuna Products from Canada, L/5198-29S/91 e United States - Imports of Certain Automotive Spring Assemblies, L/5333-30S/107. Ver tópico IV.2.2.2 do Capítulo IV infra. 
onde ela se localiza pelo valor de $\$ 100$. O custo da controladora para produzir o bem $\$ 50$. Há, assim, um lucro de \$50 que corresponde às atividades da controladora e da Subsidiária A. O preço de venda do bem entre a controladora e a Subsidiária A será definido por partes do mesmo grupo, podendo variar, portanto, entre $\$ 50$ e $\$ 100$, conforme for conveniente a estas partes. Como a alíquota de imposto de renda nos países da controladora e da subsidiária é a mesma, em princípio não há incentivo tributário para se preferir alocar lucros em uma ou outra jurisdição. Independente de onde for alocado, o lucro de \$50 será tributado à alíquota de $40 \%$ e o grupo deverá \$20 a título de imposto de renda.

Saliente-se, contudo, que somente será possível determinar a parcela do lucro de \$50 alocável a cada um dos países e tributável em cada um deles, se compararmos a transação entre as partes ligadas com outra transação entre partes independentes e, com isso, determinarmos o preço que seria praticado entre tais partes independentes (ou seja, em mercado). Aí se encontra a importância das regras de preços de transferência, como já havíamos mencionado anteriormente.

No entanto, imaginemos agora que o grupo em questão constitua uma Subsidiária B, situada em um paraíso fiscal que não tributa a renda de tal empresa. Após a constituição desta subsidiária, o bem que seria vendido diretamente da controladora para a Subsidiária A, passará a ser vendido pela controladora à Subsidiária $\mathrm{B}$, que o revenderá para a Subsidiária A. Neste caso, a controladora venderá o bem à Subsidiária B pelo preço de \$50 e a Subsidiária B venderá este mesmo bem por \$100 para a Subsidiária A.

Com esta estrutura, todo o lucro (\$50) envolvido na produção e venda ao mercado do bem em questão foi alocado na Subsidiária B, por meio da manipulação de preços nas transações entre as empresas do grupo.

Se não houver qualquer controle de preços de transferência pelos países da controladora e da Subsidiária A, o grupo escapará a tributação da renda na operação, pois a Subsidiária B não é tributada no paraíso fiscal. O imposto perdido pelo país da controladora poderia até ser recuperado quando os lucros auferidos pela Subsidiária B fossem distribuídos, ou anteriormente houver a aplicação de regras $\mathrm{CFC}^{250}$. O imposto perdido pelo país da Subsidiária A, contudo, não seria recuperado.

\footnotetext{
${ }^{250}$ Regras de transparência quanto à tributação dos lucros de determinadas subsidiárias no exterior.
} 
O exemplo ilustra como grupos multinacionais podem realocar sua renda em paraísos fiscais e, assim, escapar da tributação, ficando clara a necessidade de aplicação de regras de preços de transferência a operações desse tipo.

Contudo, o exemplo também mostra que a alocação da renda somente é possível se o grupo se valer de parte ligada residente em paraíso fiscal. Se a Subsidiária B fosse uma parte independente, a transação mencionada acima não faria sentido e não seria realizada.

Assim, ainda que seja verdade que os paraísos fiscais sejam ótimos candidatos para grupos econômicos realocarem a sua renda por meio da manipulação de preços, também é verdade que tal realocação somente se torna possível entre partes ligadas. Dessa forma, o mero fato de os paraísos fiscais não tributarem a renda não parece ser suficiente para justificar a aplicação das regras de preços de transferência brasileiras nas importações de paraísos fiscais mesmo na ausência de vínculo entre importador e exportador.

A aplicação das regras de preços de transferência na ausência de vínculo parece ser justificada apenas nos casos em que o Brasil não tem condições de determinar se há o vínculo entre a empresa brasileira e o exportador no paraíso fiscal. Trata-se da hipótese do $\S^{\circ}$ do artigo 24 da Lei $n^{\circ} 9.430 / 96$, que qualifica como paraísos fiscais o país “cuja legislação não permita o acesso a informações relativas à composição societária de pessoas jurídicas, à sua titularidade ou à identificação do beneficiário efetivo de rendimentos atribuídos a não residentes".

Nesses casos, devido à impossibilidade se verificar o vínculo entre as partes, parece-nos que a aplicação das regras de preços de transferência a todas as operações seria um meio válido para evitar a evasão e a elisão fiscal.

Por outro lado, nos casos de paraísos fiscais que permitem o acesso às informações societárias dos exportadores, permitindo que se determine se há o vínculo entre a empresa brasileira e o exportador residente no paraíso fiscal, o argumento do combate à evasão e elisão fica enfraquecido para fundamentar a aplicação dos ajustes de preços de transferência mesmo na ausência de vínculo entre as partes. 
Poder-se-ia sustentar que em muitos casos as estruturas societárias dos grupos multinacionais são tão complexas que o vínculo acaba ficando perdido. Ademais, ainda que a empresa exportadora resida em um paraíso fiscal que permite o acesso às suas informações societárias, ela pode ser detida por outra empresa em jurisdição que não divide tais informações. Nesses casos, continuará sendo impossível para a fiscalização brasileira determinar a existência do vínculo.

Argumentos como este poderiam ser utilizados para tentar defender a razão de existência das regras brasileiras, sendo incerto se a OMC iria aceitá-los caso algum dos países listados pelo Brasil como paraíso fiscal decidisse contestar as regras de preços de transferência brasileiras.

\section{II.5. GATT, Acordo TRIMS, tributação da renda e subvenções tributárias}

A análise das regras do GATT e do Acordo TRIMS mostrou que estes acordos aplicam-se a determinadas medidas de tributação da renda. Todavia, tal aplicação dependerá da comprovação de que a medida de tributação da renda efetivamente se relaciona com produtos e discrimina produtos importados entre eles (para fins da aplicação do Tratamento da Nação Mais Favorecida) ou em relação a produtos nacionais (para fins de aplicação do Tratamento Nacional e, de certa forma, do Acordo TRIMS).

Uma vez que os tributos sobre a renda incidem sobre a renda auferida por pessoas, a sua relação com produtos ocorrerá apenas em casos excepcionais. Em tais casos, a fruição de determinadas vantagens de tributação da renda pelo contribuinte é atrelada à utilização de certos produtos. Nestes casos, havendo a discriminação entre produtos nacionais e importados similares, ou a discriminação entre produtos similares de diferentes origens, o GATT e o Acordo TRIMS poderão ser aplicados.

É bastante defensável alegar que medidas deste tipo configuram subvenções tributárias veiculadas por normas de tributação da renda, pois o "padrão" destas regras é não discriminar produtos.

Os exemplos apresentados comprovam esta interpretação. 
Com efeito, regras de depreciação acelerada podem ser consideradas uma subvenção pela simples comparação com as regras de depreciação aplicáveis aos contribuintes que não gozam deste benefício.

Quanto às regras de preços de transferência, verificamos que a sua aplicação simétrica às importações e exportações não fere o GATT e o Acordo TRIMS.

Apenas a aplicação de regras mais brandas aos ajustes de preços de transferência em exportações, em relação aos ajustes nas importações, poderia ser considerada contrária a estes acordos.

Nesse caso, a aplicação assimétrica das regras de preços de transferência pode ser considerada uma subvenção tributária, pois as regras favoráveis às exportações desviariam do padrão adotado para as importações.

Da mesma maneira, a aplicação diferenciada e mais gravosa dos ajustes de preços de transferência para as importações advindas de determinados países pode ser considerada uma subvenção aos produtos advindos dos países para os quais os ajustes mais gravosos não se aplicam. 


\section{III - SUBSÍDIOS E O ASMC}

Conforme já apontamos no tópico II.1.3 do Capítulo II supra, os subsídios são considerados barreiras não tarifárias ao comércio que, na lógica do GATT, devem ser eliminadas de imediato. Neste tópico verificaremos o seu tratamento no âmbito da OMC e as consequências em relação à tributação da renda.

\section{III.1. Regime no GATT e relação com o ASMC}

Apontamos anteriormente que GATT carece de dispositivos fortes para lidar com a questão dos subsídios. O artigo III não parece oferecer sequer no seu parágrafo 4 redação adequada para lidar com o pagamento de subsídios, pois é possível questionar se o pagamento de subsídios a produtores nacionais, ainda que exclusivamente condicionados à performance em exportação, estaria efetivamente outorgando tratamento diferenciado aos produtos nacionais em relação aos produtos importados. Ademais, a limitação prevista no parágrafo 8(b) do artigo III, a qual determina que "as disposições deste artigo não impedirão o pagamento de subsídios exclusivamente a produtores nacionais compreendidos os pagamentos a produtores nacionais com recursos provenientes da arrecadação dos impostos ou tributos internos aplicados de conformidade com os dispositivos deste Artigo e de subsídios concedidos sob a forma de compra de produtos nacionais pelos poderes públicos", é genérica o suficiente para que se possa defender que o pagamento de subsídios está fora do escopo de aplicação do artigo III.

O artigo XVI do GATT, por seu turno, lida especificamente com os subsídios (ou subvenções, conforme a versão em português do acordo), considerando-os uma interferência indesejável na livre circulação de bens. A "Seção A", constante desde o GATT/47 é bastante genérica ${ }^{251}$ e impõe que qualquer país que mantenha um subsídio que aumente as exportações e diminua as importações deve notificar as partes contratantes do

\footnotetext{
${ }^{251}$ PERSIANI, Alessio, Organizzazione Mondiale del Commercio, disciplina in material di sovvenzioni ed imposizione diretta: alcune riflessioni, in Diritto e pratica tributaria internazionale, n. 2, 2007, p. 527.
} 
GATT. A "Seção B”, adicionada em $1955^{252}$, dispõe especificamente sobre os subsídios às exportações. Vejamos:

\section{"SEÇÃO A}

\section{SUBVENÇÕES EM GERAL}

1. Se uma Parte Contratante concede ou mantém uma subvenção qualquer, inclusive qualquer forma de proteção das rendas ou sustentação dos preços que tenha diretamente ou indiretamente por efeito elevar as exportações de um produto qualquer do território da referida Parte Contratante ou de reduzir as importações do mesmo no seu território, dará conhecimento, por escrito, às Partes Contratantes, não somente da importância e da natureza dessa subvenção, como dos resultados que possam ser esperados sobre as quantidades do ou dos produtos em questão por ele importados ou exportados e as circunstâncias que tornam a subvenção necessária. Em todos os casos em que fique estabelecido que uma tal subvenção causa ou ameaça causar um prejuízo sério aos interesses de outra Parte Contratante, a Parte Contratante que a concedeu examinará, quando solicitada, com a ou com as Partes Contratantes interessadas ou com as Partes Contratantes, a possibilidade de limitar a subvenção.

\section{SEÇÃO B \\ DISPOSIÇÕES ADICIONAIS RELATIVAS ÀS SUBVENÇÕES E À EXPORTAÇÃO}

2. As Partes Contratantes reconhecem que a outorga, por uma Parte Contratante, de uma subvenção à exportação de um produto pode ter conseqüências prejudiciais para outras Partes Contratantes, quer se trate de países importadores ou de países exportadores; que pode provocar

${ }^{252}$ BLIACHERIENE, Ana Carla, Subsídios: efeitos, contramedidas e regulamentação - uma análise das normas nacionais e das normas da OMC, in TORRES, Heleno Taveira (org.), Direito Tributário Internacional Aplicado, São Paulo, Quartier Latin, 2007, p. 289. 
perturbações injustificadas nos seus interesses comerciais normais e opor obstáculo à realização dos objetivos do presente Acordo.

3. Em conseqüência, as Partes Contratantes deveriam se esforçar no sentido de evitar a concessão de subvenções à exportação de produtos de base. Contudo, se uma Parte Contratante concede ${ }^{253}$ diretamente ou indiretamente, sob uma forma qualquer, uma subvenção que tenha por efeito aumentar a exportação de um produto de base originária de seu território, esta subvenção não será concedida de tal maneira que a mencionada Parte Contratante detenha então uma parte mais do que razoável do comércio mundial de exportação do mesmo produto, tendo em vista a participação das Partes Contratantes no comércio deste produto durante um período de referência anterior, assim como todos os fatores especiais que possam ter afetado ou que possam afetar o comércio em questão.

4. Além disso, a partir de $1^{\circ}$ de janeiro de 1958, ou o mais cedo possível depois desta data, as Partes Contratantes cessarão de conceder direta ou indiretamente qualquer subvenção, de qualquer natureza que ela seja, à exportação de todo produto que não seja produto de base, que tenha por resultado de reduzir o preço de venda na exportação deste produto abaixo do preço comparável cobrado aos consumidores do mercado interno para o produto similar. Até 31 de dezembro de 1957, nenhuma Parte Contratante estenderá o campo de aplicação de tais subvenções além do nível existente em $1^{o}$ de janeiro de 1955, instituindo novas subvenções ou estendendo as subvenções existentes.

5. As Partes Contratantes procederão periodicamente a um exame de conjunto da aplicação das disposições do presente artigo a fim de determinar à luz da experiência, se elas contribuem eficazmente para a realização dos objetivos do presente acordo e se elas permitem evitar efetivamente que as subvenções causem um prejuízo sério ao comércio ou aos interesses das Partes Contratantes."

\footnotetext{
${ }^{253}$ Redação de acordo com os textos oficiais em Francês e em Inglês. Na redação da Lei no ${ }^{\circ}$ 5.138/62 consta "uma parte contratante consegue".
} 
Como se pode verificar, o artigo XVI do GATT não traz uma definição de “subvenções" e, mesmo em relação às subvenções à exportação, determina uma série de testes relativamente vagos que precisavam ser aplicados para determinar se a subvenção é contrária à sua letra. Tais testes relacionam-se aos efeitos dos subsídios ${ }^{254}$ no que tange à “detenção de uma parte mais do que razoável do comércio mundial de exportação do mesmo produto", ou à "redução do preço de venda na exportação do produto abaixo do preço comparável cobrado aos consumidores do mercado interno para o produto similar”. Nesse sentido, Persiani ${ }^{255}$ aponta que, não obstante a maior incisividade das regras da Seção B do artigo XVI introduzidas em 1955, as previsões do GATT permaneceram lacunosas.

Vale notar que, ante o reconhecimento da fraca aplicação das regras de subsídios do GATT, foi estabelecido o Working Party on "Provisions of Article XVI:4" para buscar melhorar a aplicação do artigo XVI:4 ${ }^{256}$. Em 1960, o Working Party produziu a "Declaration Giving Effect to the Provisions of Article XVI:4 of the General Agreement on Tariffs and Trade" ${ }^{\text {257, }}$, aceita por dezessete partes contratantes do GATT ${ }^{258}$. Este documento trazia uma lista ilustrativa de subsidios, dentre os quais constava: "the remission, calculated in relation to exports, of direct taxes or social welfare charges on industrial or comercial enterprises".

Tendo em vista as fracas regras de subsídios do GATT, criou-se o Código de Subsídios na Rodada de Tóquio e, após extensas reformas, o ASMC, incluído na versão de 1994 do GATT, resultado da Rodada do Uruguai ${ }^{259}$, que trouxe um regime mais forte aplicável aos subsídios. O acordo traz uma definição de subsídio, reforça a disciplina sobre subsídios domésticos e define os subsídios que podem ser utilizados ${ }^{260}$.

254 STOLER, Andrew L., The evolution of subsidies disciplines in GATT and the WTO, Sidney, 2009 diponível [on line] in http://www.iit.adelaide.edu.au/conf/subsidies_usyd_0809.pdf, p. 2.

${ }^{25}$ PERSIANI, Alessio, Organizzazione Mondiale del Commercio, disciplina in material di sovvenzioni ed imposizione diretta: alcune riflessioni, in Diritto e pratica tributaria internazionale, n. 2, 2007, p. 527.

${ }^{256}$ STOLER, Andrew L., op. cit., p. 4.

257 GENERAL AGREEMENT ON TARIFS AND TRADE, Declaration giving effect on the provisions of article XVI:4 of the General Agreements on Tarifs and Trade, 1960, disponível [on line] in http://www.wto.org/gatt_docs/English/SULPDF/91870122.pdf [29.01.2011].

${ }^{258}$ Áustria, Bélgica, Canadá, Dinamarca, França, República Federal da Alemanha, Itália, Japão, Luxemburgo, Holanda, Nova Zelândia, Noruega, Suécia, Suíça, Reino Unido, Estados Unidos e Zimbábue.

259 BLIACHERIENE, Ana Carla, Subsídios: efeitos, contramedidas e regulamentação - uma análise das normas nacionais e das normas da OMC, in TORRES, Heleno Taveira (org.), Direito Tributário Internacional Aplicado, São Paulo, Quartier Latin, 2007, p. 289.

260 THORSTENSEN, Vera, OMC - Organização Mundial do Comércio: as regras do comercio internacional e a nova rodada de negociações multilaterais, 2a ed., São Paulo, Aduaneiras, 2001, p. 133. 
Conforme aponta $\operatorname{Nasser}^{261}$, a análise do acordo indica que os subsídios são considerados um instrumento cuja utilização pelos governos nacionais produz distorções ao livre comércio. Disso decorre a intenção de restringir o seu uso, que será permitido apenas em hipóteses reguladas. Estas hipóteses são estabelecidas em consideração à importância que se reconhece aos subsídios enquanto forma de cumprimento pelo Estado de seu papel de fomentador do desenvolvimento.

Portanto, conclui o autor, há dois raciocínios antagônicos que determinaram o conteúdo do acordo. O primeiro é o de que os subsídios representam distorções ao comércio internacional. O segundo é o de que os subsídios são instrumentos válidos de promoção do desenvolvimento nacional. $\mathrm{O}$ acordo procura conciliar essas duas visões.

É importante notar, por fim, que o ASMC aplica-se apenas a bens, e não a serviços $^{262}$. Acerca das regras sobre subsídios em serviços, previstas no GATS, veja-se o tópico IV.2.5 do Capítulo IV infra. Ainda, a aplicação do ASMC a produtos agrícolas é limitada pelo Acordo sobre Agricultura, conforme será apontado no tópico III.2.5 infra. Por fim, acerca da aplicação conjunta do ASMC, do artigo III do GATT e do Acordo TRIMS, ver os nossos comentários no tópico III.2.4 infra.

\section{III.2. Regime do ASMC}

\section{III.2.1. Definição de subsídio}

$\mathrm{O}$ artigo 1 do ASMC estabelece, nos seguintes termos, os elementos que devem necessariamente estar presentes para que se caracterize um subsídio:

1. Para os fins deste Acordo, considerar-se-á a ocorrência de subsídio quando:

\footnotetext{
${ }^{261}$ NASSER, Rabih Ali, Política Industrial e os Acordos da OMC: Subsídios, TRIMs e Investimentos, São Paulo, 2003, disponível [on $\quad$ line] in http://www.direitogv.com.br/AppData/Publication/PoliticaIndustrialAcordosOMCRabihNasser.pdf, [01.02.2011], pp. 5-6;

262 DALY, Michael, The WTO and direct taxation, 2005, disponível [on line] in http://www.wto.org/english/res_e/booksp_e/discussion_papers9_e.pdf [23-10-2010], p. 6. Cf. ZHOU, Zibin, The definition of subsidies under the SCM agreement, in J. Herdin-Winter, I. Hofbauer, The relevance of WTO law for tax matters, Wien, Linde, 2006, p. 313.
} 
(a) (1) haja contribuição financeira por um governo ou órgão público no interior do território de um Membro (denominado a partir daqui "governo"), i.e.:

(i) quando a prática do governo implique transferência direta de fundos (por exemplo, doações, empréstimos e aportes de capital), potenciais transferências diretas de fundos ou obrigações (por exemplo garantias de empréstimos);

(ii) quando receitas públicas devidas são perdoadas ou deixam de ser recolhidas (por exemplo, incentivos fiscais tais como bonificações fiscais) ${ }^{263}$;

(iii) quando o governo forneça bens ou serviços além daqueles destinados a infra-estrutura geral ou quando adquire bens;

(iv) quando o Governo faça pagamentos a um sistema de fundos ou confie ou instrua órgão privado a realizar uma ou mais das funções descritas nos incisos (i) a (iii) acima, as quais seriam normalmente incumbência do Governo e cuja prática não difira de nenhum modo significativo da prática habitualmente seguida pelos governos;

ou

(a) (2) haja qualquer forma de receita ou sustentação de preços no sentido do Artigo XVI do GATT 1994;

$e$

(b) com isso se confira uma vantagem.

\footnotetext{
${ }^{263}$ A nota de rodapé 1 do ASMC, inserida neste item, dispõe que "De acordo com as disposições do Artigo XVI do GATT 1994 (nota do Artigo XVI) e de acordo com os anexos I a III deste acordo, não serão consideradas como subsídios as isenções em favor de produtos destinados a exportação, de impostos ou taxas habitualmente aplicados sobre o produto similar quando destinado ao consumo interno, nem a remissão de tais impostos ou taxas em valor que não exceda os totais devidos ou abonados". Esta nota de rodapé será analisada no tópico III.5 infra.
} 
2. Um subsídio, tal como definido no parágrafo 1, apenas estará sujeito às disposições da PARTE II ou às disposições das PARTES III ou V se o mesmo for específico, de acordo com as disposições do Artigo $2 .^{264}$

Esta definição de subsídio possui dois requisitos separados. O primeiro deles é a configuração de uma contribuição financeira, nos termos da alínea (a)1 do parágrafo 1 e respectivos itens. O segundo elemento é a conferência de uma vantagem, nos termos da alínea (b) do parágrafo 1.

A expressão "contribuição financeira" é definida de maneira ampla ${ }^{265}$ pelo artigo 1:1(a). São contribuições realizadas pelo Estado, ou algum órgão público interno, e incluem não apenas a transferência direta de fundos, mas também as receitas públicas renunciadas.

Nesses termos, a definição de subsídio inclui não apenas ações positivas (um dar ou fazer; e.g., a transferência de fundos) de um governo ou de um órgão público, mas também ações negativas, dentre as quais a renúncia de receitas públicas ${ }^{266}$. No tópico III.3 infra, exploraremos este conceito e a sua aplicação à tributação da renda.

Outras formas de subsídios são o fornecimento, pelo governo, de bens ou serviços além daqueles de infraestrutura geral e os pagamentos governamentais a fundos que, por sua vez, realizarão a transferência direta a determinadas empresas ou setores industriais.

O segundo requisito para a configuração de um subsídio é que uma vantagem seja conferida.

\footnotetext{
${ }^{264}$ Conforme salienta Schoueri, o artigo $4^{\circ}$ do Decreto $n^{\circ} 1.751 / 95$, sob o pretexto de regulamentar esta matéria, acresce entre os casos de subsídio e em alternativa àquilo que prevê a $\mathrm{OMC}$, a hipótese em que haja, no país exportador, qualquer forma de sustentação de renda ou de preços que, direta ou indiretamente, contribua para aumentar exportações ou reduzir importações de qualquer produto. SCHOUERI, Luís Eduardo, Normas tributárias indutoras e intervenção econômica, Rio de Janeiro, Forense, 2005, p 211

${ }^{265}$ ZHOU, Zibin, The definition of subsidies under the SCM agreement, in J. Herdin-Winter, I. Hofbauer, The relevance of WTO law for tax matters, Wien, Linde, 2006, p. 316.

${ }^{266}$ PERSIANI, Alessio, Organizzazione Mondiale del Commercio, disciplina in material di sovvenzioni ed imposizione diretta: alcune riflessioni, in Diritto e pratica tributaria internazionale, n. 2, 2007, p. 535.
} 
Para se determinar se há uma vantagem, é necessário verificar se a contribuição financeira colocou o seu beneficiário em uma posição mais vantajosa do que aquela em que este se encontrava (ou se encontraria) sem tal contribuição ${ }^{267}$.

Nesse sentido, pode-se dizer que há um benefício, ou vantagem, se a contribuição financeira foi oferecida em termos mais vantajosos do que aqueles que o recipiente poderia ter conseguido no mercado ${ }^{268}$.

\section{III.2.2. Especificidade}

O parágrafo 2 do artigo 1 esclarece que um subsídio somente se sujeitará às regras das partes II, III ou V do ASMC (ou seja, o subsídio somente será proibido ou recorrível e sujeito à aplicação das medidas compensatórias) se for específico, ou seja, concedido a um grupo de empresas ou indústrias específico no âmbito da jurisdição da autoridade concedente. São estes subsídios que, do ponto de vista econômico, têm a maior probabilidade de afetarem o livre comércio ${ }^{269}$.

$\mathrm{O}$ artigo 2 do ASMC determina nos seguintes termos as condições dentro das quais haverá a especificidade:

1. Com vistas a determinar se um subsidio, tal como definido no parágrafo 1 do Artigo 1, destina-se especificamente a uma empresa ou produção, ou a um grupo de empresas ou produções (denominadas neste Acordo de "determinadas empresas"), dentro da jurisdição da autoridade outorgante, serão aplicados os seguintes princípios:

(a) o subsídio será considerado específico quando a autoridade outorgante, ou a legislação pela qual essa autoridade deve reger-se, explicitamente limitar o acesso ao subsídio a apenas determinadas empresas;

\footnotetext{
${ }^{267}$ ZHOU, Zibin, The definition of subsidies under the SCM agreement, in J. Herdin-Winter, I. Hofbauer, The relevance of WTO law for tax matters, Wien, Linde, 2006, p. 317. Cf. Relatório do Órgão de Apelação em Canada - Measures Affecting The Export Of Civilian Aircraft, parágrafo 157, PP. 40-41.

268 THORSTENSEN, Vera, OMC - Organização Mundial do Comércio: as regras do comercio internacional e a nova rodada de negociações multilaterais, $2^{\mathrm{a}}$ ed., São Paulo, Aduaneiras, 2001, p. 134.

${ }^{269}$ PERSIANI, Alessio, Organizzazione Mondiale del Commercio, disciplina in material di sovvenzioni ed imposizione diretta: alcune riflessioni, in Diritto e pratica tributaria internazionale, $n .2$, 2007, p. 550.
} 
(b) não ocorrerá especificidade quando a autoridade outorgante, ou a legislação pela qual essa autoridade deve reger-se, estabelecer condições ou critérios objetivos ${ }^{270}$ que disponham sobre o direito de acesso e sobre o montante a ser concedido, desde que o direito seja automático e que as condições e critérios sejam estritamente respeitados. As condições e critérios deverão ser claramente estipulados em lei, regulamento ou qualquer outro documento oficial, de tal forma que se possa proceder à verificação;

(c) se apesar de haver aparência de não-especificidade resultante da aplicação dos princípios estabelecidos nos subparágrafos $(a)$ e (b), houver razoes para acreditar-se que o subsídio em consideração seja de fato específico, poder-se-ão considerar outros fatores como: uso predominante de um programa de subsídios por número limitado de empresas, concessão de parcela desproporcionalmente grande do subsídio a determinadas empresas apenas e o modo pelo qual a autoridade outorgante exerceu seu poder discricionário na decisão de conceder um subsídio ${ }^{271}$. Na aplicação deste subparágrafo será levada em conta a diversidade das atividades econômicas dentro da jurisdição da autoridade outorgante, bem como o período de tempo durante o qual o programa de subsídios esteve em vigor;

2. Será considerado específico o subsídio que seja limitado a determinadas empresas localizadas dentro de uma região geográfica situada no interior da jurisdição da autoridade outorgante. Fica entendido que não se considerara subsídio específico para os propósitos do presente Acordo o estabelecimento ou a alteração de $\operatorname{taxas}^{272}$ geralmente aplicáveis por todo e qualquer nível de governo com competência para fazêe-lo.

\footnotetext{
${ }^{270}$ A nota de rodapé 2 determina que: “a expressão 'condições ou critérios objetivos', tal como usada neste acordo, significa condições ou critérios neutros, isto é, que não favorecem determinadas empresas em detrimento de outras e que são de natureza econômica e de aplicação horizontal, tais como número de empregados e dimensão da empresa".

${ }^{271}$ A nota de rodapé 3 determina que "a esse respeito deverão ser levadas em consideração informações sobre a frequência com que sejam recusados ou aprovados pedidos de subsídios e sobre os motivos que levaram a tais decisões".

${ }^{272}$ A versão oficial em inglês do ASMC utiliza a expressão "setting or change of generally applicable tax rates". Assim, em nossa visão, a redação correta em português seria o "estabelecimento ou alteração da alíquota de tributos". Não se deve ler o termo taxas empregado na versão em português como uma redução à espécie tributária "taxas" do ordenamento brasileiro.
} 
3. Quaisquer subsídios compreendidos nas disposições do Artigo 3 serão considerados específicos.

4. Qualquer determinação de especificidade ao abrigo do disposto neste Artigo deverá estar claramente fundamentada em provas positivas.

Deve-se notar, em primeiro lugar, a regra do parágrafo 3 do artigo 2, que estabelece que, se um subsídio enquadrar-se na definição de "subsídio proibido" constante do artigo 3 do ASMC, ele automaticamente será considerado específico.

Há certa tautologia entre a regra do artigo 2:3 e aquela constante do artigo 1:2. Relembrando, o artigo 1:2 determina que a Parte II do ASMC (na qual se inclui o artigo 3) somente se aplicará a um subsídio se ele for específico nos termos do artigo 2. Por sua vez o artigo 2 presume que o subsídio será específico se o artigo 3 se aplicar. Ora, se a aplicação do artigo 3 depende do teste da especificidade, como é possível que a presunção de especificidade dependa da aplicação do artigo 3 ?

Esta questão, em nossa visão, é resolvida pela análise do próprio artigo 3 (ver tópico III.2.1.3 infra), que mostra que os subsídios proibidos, vinculados à exportação ou ao uso preferencial de produtos nacionais, efetivamente preenchem os requisitos de especificidade veiculados pelo artigo 2. Nesse sentido, a presunção apenas aclara este ponto e dispensa a realização do teste do artigo 2 quando se tratar de um subsídio que claramente se enquadra no artigo 3. Entendemos que a regra do artigo 1:2 deve ser temperada com estas considerações, para que não se caia em um raciocínio tautológico.

Fora das hipóteses da presunção em relação ao artigo 3, deve-se determinar a especificidade do subsidio em conformidade com os parágrafos 1 e 2 do artigo 2. As alíneas (a) e (b) do parágrafo 1 lidam com a especificidade de direito, enquanto a alínea (c) lida com a especificidade de fato. O parágrafo 2 trata da especificidade em decorrência de limitação geográfica.

Haverá especificidade se a autoridade outorgante do subsídio, ou a legislação aplicável, explicitamente limitar o seu acesso a um grupo de empresas ou produção. Todavia, não haverá especificidade se a autoridade ou a legislação estabelecerem critérios objetivos neutros sobre o direito de acesso ao subsídio e sobre o montante a ser concedido 
e desde que a concessão do subsídio seja automática. Ainda, os critérios para acesso ao subsídio devem ser de natureza e de aplicação horizontal (como, por exemplo, número de empregados ou dimensão da empresa) e não devem favorecer determinadas empresas em detrimento de outras.

Independentemente dessas regras, é possível constatar que o subsídio é, de fato, específico, nos termos do parágrafo 1(c), em decorrência, por exemplo, do seu uso predominante por número limitado de empresas, da concessão de parcela desproporcionalmente grande do subsídio a determinadas empresas, e do modo pelo qual a autoridade outorgante exercer seu poder discricionário na decisão de conceder um subsídio.

Por fim, o parágrafo 2 estabelece que será específico o subsídio limitado a determinadas empresas localizadas dentro de uma região geográfica situada no interior da jurisdição da autoridade outorgante.

É bastante relevante nesse contexto a exceção feita pela segunda frase do parágrafo 2, que determina que não se considerara subsídio específico para os propósitos ASMC o estabelecimento ou a alteração, por todo e qualquer nível de governo com competência para fazê-lo, de tributos geralmente aplicáveis.

Ou seja, a mera redução geral de alíquota de um tributo não será considerada um subsídio específico. Ademais, tal redução pode ser feita por qualquer ente tributante, em qualquer nível de governo do país em questão. Ainda que a competência tributária de um ente tributante restrinja-se apenas a uma porção do território de um país, uma redução geral na alíquota do tributo de competência daquele ente tributante, apesar de afetar somente parte do território do país, não será considerada um subsídio geograficamente específico nos termos do artigo 2:2.

Conforme veremos no tópico III.3 infra, esta exceção complementa o próprio conceito de "receitas públicas perdoadas ou que deixam de ser recolhidas" constante do artigo 1:1(a)(1)(ii) e se coaduna com a análise das subvenções tributárias. 


\section{III.2.3. Categorias de subsídios}

Superadas as questões da definição e especificidade, cumpre verificarmos a classificação dos subsídios feita pelo ASMC e as suas consequências.

Conforme aponta Nasser ${ }^{273}$, em consideração aos dois prismas sob os quais pode ser vista a questão dos subsídios (i.e., subsídios como distorções ao comércio versus subsídios como ferramenta de promoção do desenvolvimento), o acordo classifica os subsídios em três categorias, no que se refere à licitude de sua utilização: proibidos (ou vermelhos), recorríveis (amarelos, ou acionáveis) e irrecorríveis (verdes, ou não acionáveis).

O conceito fundamental no qual se assenta essa classificação é o de "prejuízo potencial", fundado na avaliação dos efeitos negativos que os subsídios tendem a produzir para o funcionamento do comércio internacional.

\section{III.2.3.1. Subsídios proibidos}

Os subsídios proibidos são aqueles arquitetados para afetar diretamente o comércio internacional $^{274}$ e sua utilização é vedada em quaisquer circunstâncias ${ }^{275}$. Tais subsídios dividem-se em duas categorias, quais sejam: (i) subsídios de exportação; e (ii) subsídios de conteúdo local ${ }^{276}$.

O artigo 3:1(a) define os subsídios à exportação como "subsídios vinculados de fato ou de direito ao desempenho exportador, quer individualmente, quer como parte de um conjunto de condições, inclusive aqueles indicados a título de exemplo no Anexo I".

\footnotetext{
${ }^{273}$ NASSER, Rabih Ali, Política Industrial e os Acordos da OMC: Subsídios, TRIMs e Investimentos, São Paulo, 2003, [on disponível line] http://www.direitogv.com.br/AppData/Publication/PoliticaIndustrialAcordosOMCRabihNasser.pdf, [01.02.2011], p. 8.

${ }^{274}$ ZHOU, Zibin, The definition of subsidies under the SCM agreement, in J. Herdin-Winter, I. Hofbauer, The relevance of WTO law for tax matters, Wien, Linde, 2006, p. 319.

${ }^{275}$ NASSER, Rabih Ali, op. cit, p. 8.

${ }^{276}$ ZHOU, Zibin, op. cit., p. 319.
} 
Haverá o vínculo de direito ao desempenho exportador quando se puder demonstrar com base na legislação que o subsídio é condicionado, ainda que implicitamente, a exportações ${ }^{277}$.

A nota de rodapé $\mathrm{n}^{\circ} 4$ determina que haverá o vínculo de fato "quando os fatos demonstrarem que a concessão de um subsídio, ainda que não esteja vinculada de direito ao desempenho exportador, está de fato vinculada a exportações ou ganhos com exportações reais ou previstos. O simples fato de que subsídios sejam concedidos a empresas exportadoras não deverá, por si só, ser considerado como subsídio a exportação, no sentido definido neste artigo."

Os subsídios de conteúdo local são definidos no artigo 3:1(b) do ASMC como "subsídios vinculados de fato ou de direito ao uso preferencial de produtos nacionais em detrimento de produtos estrangeiros, quer individualmente, quer como parte de um conjunto de condições".

Diferentemente do que ocorre com os subsídios de exportação, o ASMC não traz lista exemplificativa dos subsídios de conteúdo local. Ainda assim, é possível entender que tais subsídios também se aplicam a medidas tributárias, pois medidas tributárias enquadram-se no conceito de subsídio constante do artigo 1:1(a)(1)(ii). Dentre estas medidas, incluem-se aquelas relativas à tributação da renda, conforme veremos adiante.

Nasser $^{278}$ aponta que os subsídios de conteúdo local funcionam em geral como uma vantagem que se confere a investidores, em contrapartida à submissão por estes a Trims que impõem determinado grau de nacionalização da produção. Assim, a proibição desse tipo de subsídios complementa a proibição contida no artigo 2 do Acordo TRIMS.

Nesses termos, valem para os subsídios de conteúdo local as considerações feitas nos tópicos II.3.2 e II.4.1 do Capítulo II supra em relação à aplicação do Acordo TRIMS a determinadas medidas de tributação da renda. No que tange à aplicação conjunta

\footnotetext{
${ }^{277}$ ZHOU, Zibin, The definition of subsidies under the SCM agreement, in J. Herdin-Winter, I. Hofbauer, The relevance of WTO law for tax matters, Wien, Linde, 2006, p. 319.

${ }^{278}$ NASSER, Rabih Ali, Política Industrial e os Acordos da OMC: Subsídios, TRIMs e Investimentos, São Paulo, 2003, disponível [on $\quad$ line] in http://www.direitogv.com.br/AppData/Publication/PoliticaIndustrialAcordosOMCRabihNasser.pdf, [01.02.2011], p. 9 .
} 
do artigo 3:1(b) do ASMC com o Acordo TRIMS e o artigo III do GATT, ver nossos comentários no tópico III.2.4 infra.

Por fim, o artigo 6 do ASMC prevê os recursos aplicáveis caso um Membro entenda que um subsídio proibido está sendo concedido por outro Membro. O primeiro pode: (i) pedir consultas ao outro Membro e chegar a uma solução satisfatória; e/ou (ii) pedir o estabelecimento de um painel para analisar o conflito, dentro do Mecanismo de Solução de Controvérsias da OMC e, se for o caso, aplicar contramedidas apropriadas caso o outro Membro não cesse a concessão do subsídio ${ }^{279}$.

\section{III.2.3.2. Subsídios recorríveis}

Os subsídios recorríveis, regulados pelos artigos 5, 6 e 7 do ASMC, são aqueles cuja utilização só é vedada na medida em que eles possam produzir determinados efeitos considerados danosos. Ou seja, tais subsídios não são proibidos, mas a sua utilização está sujeita a contestação. A caracterização da ilegalidade do uso dos subsídios recorríveis depende da demonstração dos efeitos nocivos deles decorrentes ${ }^{280}$.

Nesses termos, um subsídio não poderá ser concedido se causar os "efeitos danosos" apontados pelo artigo 5 do ASMC, que consistem em: (i) dano à indústria nacional de outro Membro; (ii) anulação ou prejuízo de vantagens resultantes para outros Membros, direta ou indiretamente, do GATT 1994, em especial as vantagens de concessões consolidadas sob o Artigo II do GATT 1994; ou (iii) "grave dano" aos interesses de outro Membro.

O artigo 6 traz as condições para a caracterização do "grave dano" previsto na alínea (c) do artigo 5. O parágrafo 1 do artigo 6 não mais se aplica em virtude da sua expiração, conforme o artigo 31 do ASMC. Nesses termos, a configuração de grave dano

\footnotetext{
279 THORSTENSEN, Vera, OMC - Organização Mundial do Comércio: as regras do comercio internacional e a nova rodada de negociações multilaterais, $2^{\mathrm{a}}$ ed., São Paulo, Aduaneiras, 2001, p. 136. ${ }^{280}$ NASSER, Rabih Ali, Política Industrial e os Acordos da OMC: Subsídios, TRIMs e Investimentos, São Paulo, 2003, disponível lon $\quad$ line] in http://www.direitogv.com.br/AppData/Publication/PoliticaIndustrialAcordosOMCRabihNasser.pdf, [01.02.2011], p. 9 .
} 
dependerá de o subsídio gerar um ou mais dos efeitos enumerados no parágrafo 3 do artigo 6, quais sejam:

“( a) deslocar ou impedir a importação de produto similar produzido por outro Membro no mercado do Membro outorgante do subsídio;

(b) deslocar ou impedir a exportação de produto similar produzido por um Membro no mercado de terceiro pais;

(c) provocar significativa redução do preço do produto subsidiado em relação ao preço do produto similar de outro Membro no mesmo mercado ou significativa contenção de aumento de preços, redução de preços ou perda de vendas no mesmo mercado;

(d) aumentar a participação no mercado mundial de determinado produto primário ou de base subsidiado pelo Membro outorgante, quando se compara com a participação média que o Membro detinha no período de três anos anteriores e quando tal aumento se mantém como firme tendência durante algum tempo após a concessão dos subsídios."

O Membro que se sentir prejudicado por um subsídio recorrível pode se valer dos recursos previstos no artigo 7 do ASMC, havendo a possibilidade de se seguir o procedimento de consulta ou de se estabelecer um painel dentro do Mecanismo de Solução de Controvérsias da $\mathrm{OMC}^{281}$.

\section{III.2.3.3. Subsídios irrecorríveis}

Os subsídios irrecorríveis, regulados nos artigos 8 e 9 do ASMC, são aqueles cuja utilização não pode ser questionada. Nos termos do artigo 8, os subsídios são irrecorríveis sempre que não preencherem o requisito da especificidade previsto no artigo 1 ou se, sendo específicos, enquadrarem-se em uma das seguintes espécies de subsídios: (i) assistência para atividades de pesquisa; (ii) assistência a região economicamente 
desfavorecida; ou (iii) assistência para promover adaptação de instalações a exigências ambientais $^{282}$.

O artigo 9 contém regras a respeito dos recursos de que um Estado Membro pode dispor no caso de considerar que os subsídios irrecorríveis concedidos por outro Membro provocaram efeitos danosos e de difícil reparação sobre sua indústria nacional. Verifica-se, portanto, que a permissão para utilização dos subsídios irrecorríveis não é absoluta. Em casos extremos, eles também podem ser questionados ${ }^{283}$.

Nas disposições finais do ASMC, o artigo 31 estabelece que os artigos 8 e 9 seriam aplicados por um período de 5 anos, após o qual o seu funcionamento seria analisado pelo comitê encarregado da administração do acordo, para determinar se as medidas deveriam ser prorrogadas, sob a mesma ou nova redação ${ }^{284}$.

Transcorrido o prazo de 5 anos, não se chegou a acordo sobre o destino a ser dado a essa categoria de subsídios. Assim, entende-se que esses dispositivos estão revogados enquanto não se decidir sobre sua continuidade. Portanto, não haveria mais que se falar, a partir de $1^{\circ}$ de dezembro de 2000 , em subsídios irrecorríveis. Haveria apenas os subsídios proibidos e os recorríveis ${ }^{285}$.

\section{III.2.4. Relação com o GATT e com o Acordo TRIMS}

No que tange à relação entre o GATT e o ASMC, deve-se observar, em primeiro lugar, a regra interpretativa geral do Anexo 1A do Acordo que Cria a Organização Mundial do Comércio ("Acordo Constitutivo da OMC"), a qual determina que, havendo conflito entre uma regra do GATT e uma regra de qualquer outro acordo constante do Anexo 1A (que inclui o ASMC), a regra do acordo do Anexo 1A deve prevalecer.

\footnotetext{
${ }^{282}$ NASSER, Rabih Ali, Política Industrial e os Acordos da OMC: Subsídios, TRIMs e Investimentos, São Paulo, 2003, disponível [on line] http://www.direitogv.com.br/AppData/Publication/PoliticaIndustrialAcordosOMCRabihNasser.pdf, [01.02.2011], p. 10 .

${ }^{283}$ Idem, ibidem, p. 10.

${ }^{284}$ Idem, ibidem, p. 10.

${ }^{285}$ Idem, ibidem, p. 10.
} 
Nesse sentido, o Painel no caso Brazil - Measures Affecting Desiccated Coconut $^{286}$ decidiu que regras sobre subsídios do GATT não poderiam ter significado independente não regulado pelo ASMC. Todavia, o próprio Painel reconheceu que a questão não é simples e deve ser analisada caso a caso.

Questão interessante refere-se à possível superposição entre o artigo III do GATT, o artigo 2:1 do Acordo TRIMS e item 1 do respectivo Anexo, e o artigo 3.1(b) do ASMC. Trata-se dos subsídios de conteúdo local que são abrangidos por todos estes dispositivos. Em princípio não há conflito na sua aplicação conjunta, mas, como mostrou o caso Indonesia - Certain Measures Affecting the Automobile Industry ${ }^{287}$, o conflito pode ocorrer.

No caso, a legislação da Indonésia outorgava isenção de seu imposto de importação para peças automotivas importadas para serem aplicadas como insumo na produção de automóveis no país. A isenção, todavia, era condicionada à utilização de um montante mínimo de insumos nacionais da Indonésia na fabricação dos automóveis. Paralelamente, a Indonésia também outorgava uma isenção do seu imposto sobre bens de luxo na venda dos automóveis, sendo que esta isenção também era condicionada à utilização de um montante mínimo de insumos de origem indonésia na fabricação dos automóveis.

Todas as partes concordavam que a medida em questão enquadrava-se no conceito de subsídio proibido constante do artigo 3:1(b). Todavia, a Indonésia alegava que poderia se valer do artigo 27:3 do ASMC, o qual prevê que a proibição do parágrafo 1 (b) do Artigo 3 não se aplicaria aos Membros em desenvolvimento pelo período de 5 anos a partir da data de entrada em vigor do Acordo Constitutivo da OMC.

Os Estados Unidos, Japão e Comunidade Europeia alegavam, por outro lado, que o artigo III do GATT e o Acordo TRIMS também se aplicavam ao caso e que as medias indonésias eram vedadas por ambos. Ainda, apesar de o Acordo TRIMS prever no seu artigo 5:2 um período de transição de 5 anos para países em desenvolvimento, de modo similar ao do artigo 27:3 do ASMC, a Indonésia não poderia se valer deste benefício porque não tinha cumprido com suas obrigações de notificação e havia modificado o

\footnotetext{
${ }^{286} \mathrm{WT} / \mathrm{DS} 22 / \mathrm{R}$.

${ }^{287}$ WT/DS54/R, WT/DS55/R, WT/DS59/R e WT/DS64/R, parágrafos 14.29 a 14.55, pp. 330-335.
} 
conteúdo dos programas de benefícios fiscais após a entrada em vigor do Acordo TRIMS (descumprindo, assim, a condição de não modificação, necessária para que o período de transição pudesse se aplicar).

Nesse cenário, a Indonésia defendia que os benefícios fiscais em questão deveriam se sujeitar apenas ao ASMC. Na visão da Indonésia, o fato de os subsídios qualificarem-se no ASMC e por ele serem permitidos colocava-os fora do escopo da análise do artigo III do GATT e do Acordo TRIMS. Entender de forma diversa, argumentava, reduziria à inutilidade as regras do ASMC.

O Painel não acatou a linha de raciocínio da Indonésia. Na visão do Painel, o artigo III do GATT e Acordo TRIMS teriam escopos diversos do ASMC. O artigo III do GATT não se relacionaria com o subsídio em si; da mesma maneira que o Acordo TRIMS, ele vedaria o tratamento diferenciado entre produtos nacionais e importados em relação a uma Trim que veicule alguma exigência de conteúdo local.

Ou seja, na visão do Painel uma regra que veicule um subsídio pode se sujeitar a análise sob o ASMC e também sob o artigo III do GATT e o Acordo TRIMS. Desta forma, o ASMC não deve ser visto como lei especial, ainda que o seu artigo III.1(b) lide com medidas que também podem se enquadrar no artigo III do GATT e no Acordo TRIMS.

\section{III.2.5. ASMC e o Acordo sobre Agricultura}

O Acordo sobre Agricultura lida com questões relacionadas a subsídios aos produtos agrícolas cobertos pelo Acordo. Não nos aprofundaremos, neste trabalho, no regime de subsídios deste acordo, por fugir ao nosso escopo. Limitar-nos-emos a apontar, neste tópico, algumas questões relevantes no que tange à sua relação com o ASMC e com as subvenções tributárias.

O artigo 1 do Acordo sobre Agricultura, ao definir "desembolsos orçamentários" ou "desembolsos", deixa claro que eles compreendem a renúncia fiscal. 
Isso faz com que as subvenções tributárias entrem no rol de subsídios à exportação cobertos pelo acordo nos termos do artigo $9^{288}$.

Todavia, a disciplina dos subsídios no Acordo sobre Agricultura diferencia-se daquela do ASMC. O Acordo sobre Agricultura adota um sistema de três "caixas" - (i) verde que contém subsídios permitidos porque causam distorções mínimas, incluindo subsídios a pesquisa e desenvolvimento e proteção ambiental; (ii) azul, que contém subsídios permitidos desde que não gerem aumento de produção; e (iii) âmbar, que contém as medidas de apoio interno definidas no artigo 6, incluindo subsídios diretamente relacionados a quantidades de produção - para diferenciar os subsídios, mas trabalha em um sistema de compromissos para a progressiva redução dos níveis de subsídios $^{289}$.

O ASMC não se aplica às matérias que o Acordo sobre Agricultura disciplinar, ou em relação às quais houver exclusão expressa no próprio ASMC. Todavia, fora estes casos, por força do artigo 21 do Acordo sobre Agricultura, que determina que "aplicar-seão as disposições do GATT 1994 e dos demais Acordos Multilaterais de Comércio que figuram no Anexo $1 A$ do Acordo Constitutivo da OMC, sujeitos às disposições do presente Acordo", o ASMC aplica-se.

\section{III.3. Aplicação à tributação da renda}

Para compreender a aplicação do ASMC à tributação da renda, devemos retornar à definição de "contribuição financeira" constante da alínea (a)(1) do artigo 1. O item (ii) desta alínea esclarece que haverá uma contribuição financeira "quando receitas públicas devidas são perdoadas ou deixam de ser recolhidas (por exemplo, incentivos fiscais tais como bonificações fiscais)".

Ou seja, há uma contribuição financeira quando uma determinada receita governamental que, na ausência da medida em questão seria devida, é despendida ou não arrecadada.

\footnotetext{
${ }^{288}$ ZHOU, Zibin, The definition of subsidies under the SCM agreement, in J. Herdin-Winter, I. Hofbauer, The relevance of WTO law for tax matters, Wien, Linde, 2006, p. 326; DALY, Michael, The WTO and direct taxation, 2005, disponível [on line] in http://www.wto.org/english/res_e/booksp_e/discussion_papers9_e.pdf [23-10-2010], p. 7.

${ }^{289}$ DALY, Michael, op. cit., p. 7.
} 
Esta definição pede a aplicação do chamado de teste "but-for", para determinar se uma norma veicula um subsídio. Tal teste baseia-se na sentença "government revenue that is otherwise due is foregone or not collected" constante da versão em inglês do artigo 1(a)(1)(ii) do ASMC. A expressão "otherwise due" refere-se à situação que ocorreria se não fosse (“but for") a medida em questão.

Zhou ${ }^{291}$ ressalta a necessidade de definir-se um parâmetro normativo em relação ao qual se poderá comparar a receita efetivamente recolhida com a receita que teria sido recolhida. A diferença entre a situação parâmetro e a situação de fato será o montante do subsídio.

Nesse sentido, o artigo 1(a)(1)(ii) do ASMC parece exigir a aplicação do modelo das tax expenditures analisado no Capítulo I deste trabalho ${ }^{292}$ para que se verifique a existência de um subsídio veiculado por meio de normas tributárias.

Nada na redação do artigo 1 exclui os tributos sobre a renda de seu escopo. O Anexo I do ASMC, que fornece uma lista ilustrativa de subsídios (proibidos) à exportação, confirma que o artigo 1(a)(1)(ii) é aplicável aos tributos sobre a renda ao apontar, nos seus itens (e) e (f), medidas de tributação da renda como subsídios à exportação. Vejamos:

“(e) Isenção, remissão ou deferimento total ou parcial, concedido especificamente em função de exportações, de impostos diretos ou impostos sociais pagos ou pagáveis por empresas industriais ou comerciais.

(f) A concessão, no cálculo da base sobre a qual impostos diretos são aplicados, de deduções especiais diretamente relacionadas com as exportações ou com o desempenho exportador, superiores aquelas concedidas à produção para consumo interno."

\footnotetext{
${ }^{290}$ FOLTYN, Olga, The exemption method and fictitious tax credit as a prohibited subsidy under WTO law, in J. Herdin-Winter, I. Hofbauer, The relevance of WTO law for tax matters, Wien, Linde, 2006, p. 383.

${ }^{291}$ ZHOU, Zibin, The definition of subsidies under the SCM agreement, in J. Herdin-Winter, I. Hofbauer, The relevance of WTO law for tax matters, Wien, Linde, 2006, 329.

${ }^{292}$ McDANIEL, Paul R., The impact of trade agreements on tax systems, in INTERTAX, v. 30, issue 5, 2002. BRAUNER, Yariv, International trade and tax agreements may be coordinated, but not reconciled, in Virginia Tax Review (2005), pp. 290-291.
} 
Aponte-se novamente que a nota de rodapé $n^{\circ} 58$ do ASMC deixa claro que impostos diretos ${ }^{293}$ abrangem a tributação da renda.

No que tange aos subsídios de conteúdo local, ainda que o ASMC não traga uma lista ilustrativa, vimos no tópico II.3.2 do Capítulo II supra que eles podem ser veiculados por meio de regras de tributação da renda que configuram subvenções tributárias.

Assim, não há como negar que o ASMC aplica-se à tributação da renda. Em decorrência de expressa determinação do artigo 1(a)(1)(ii), para verificar se uma medida de tributação da renda constituiu um subsídio, é necessário determinar um "parâmetro" normativo, em relação ao qual comparará a medida em questão, a fim de se constatar se, no caso concreto, há a efetiva renúncia de receitas pelo Estado Membro.

Conforme demonstraremos no tópico III.4 a seguir, a identificação deste parâmetro gerou grandes controvérsias nos casos DISC e FSC/ETI, nos quais os painéis e o Órgão de Apelação tiveram que lidar com questões bastante complexas atinentes aos sistemas de tributação da renda dos Estados Membros.

Estes casos mostram a dificuldade de se estabelecer uma estrutura parâmetro em relação aos sistemas tributários dos Estados Membros para se determinar algumas regras de tributação da renda efetivamente veiculam subvenções proibidas pelo GATT e pelo ASMC.

\section{III.4. Casos no âmbito do GATT/OMC}

\section{III.4.1. DISC}

As regras DISC (Domestic International Sales Corporations) surgiram em 1971, momento em que os EUA eram o único país a adotar regras CFC e tributação universal da renda. Em virtude disso, surgiu a necessidade de este país excluir alguns

\footnotetext{
293 “'O termo 'impostos diretos' significa impostos sobre salários, lucros, juros, rendas, direitos de autor e
} todas as outras formas de ganho, além de impostos sobre a propriedade de bens imóveis" 
rendimentos da aplicação do seu regime universal ${ }^{294}$, a fim de aumentar a sua competitividade internacional. Tal necessidade levou ao nascimento das regras DISC.

As empresas DISC eram empresas constituídas nos Estados Unidos que deveriam ter $95 \%$ de seus ativos voltados para atividades de exportação, bem como $95 \%$ de sua renda bruta decorrente de atividades relacionadas a exportações ${ }^{295}$.

Empresas americanas que produziam bens para exportação constituíam uma subsidiária que se qualificava como uma DISC. Os bens eram alienados pelas produtoras para as suas subsidiárias DISC e estas os exportavam.

A renda das DISC não era tributada quando auferida, mas apenas quando houvesse a sua distribuição para a controladora. Por seu turno, as regras de preços de transferência aplicáveis para as transações entre a controladora e a subsidiária DISC permitiam que $50 \%$ do efetivo lucro da operação fosse alocado para a DISC e $50 \%$ fosse alocado para a controladora. Como metade do lucro da DISC era considerada automaticamente distribuída para a controladora, o resultado final era que $25 \%$ do total dos lucros auferidos pelo grupo na venda de bens para a exportação poderia ser diferido na DISC, sem tributação pelo imposto de renda enquanto não fosse efetivamente distribuído para a controladora ${ }^{296}$. Não havia a cobrança de juros sobre este valor diferido, que poderia se estender por longuíssimo prazo.

A Comunidade Europeia contestou, sob o artigo XVI:4 do GATT, a possibilidade da adoção destas regras pelos EUA. A Comunidade Europeia sustentou que a possibilidade de diferimento, por prazo indeterminado e sem a aplicação de juros, da tributação dos lucrosadvindos da exportação constituiria um subsídio à exportação vedado pelo artigo XVI do GATT e pelos itens (c) e (d) da Declaration giving effect on the provisions of article XVI:4 of the General Agreements on Tarifs and Trade, assinada pelos EUA.

\footnotetext{
${ }^{294}$ DESAI, Mihir A., HINES Jr., James R., The uneasy marriage of export incentives and the income tax, Cambridge-MA, 2000, disponível [on-line] in www.nber.org/papers/w8009 [23.10.2005], pp. 17-18.

${ }^{295}$ Relatório do Painel em United States - Tax Legislation (DISC), L/4422-23S/98, parágrafo 11, p. 2. McDANIEL, Paul R., Trade agreements and income taxation: interactions, conflicts, and resolutions, Boston, 2004, disponível [on line] in http://www.un.org/esa/ffd/aconf198-11.pdf [05.11.2005], p. 3.

${ }^{296}$ Relatório do Painel em United States - Tax Legislation (DISC), L/4422-23S/98, parágrafo 14, p. 2.
} 
Em resposta, os EUA sustentaram, em primeiro lugar, que o simples diferimento não poderia ser considerado um subsídio.

Em segundo lugar, os EUA apontaram que as regras DICS apenas replicavam o efeito dos regimes de tributação territorial adotados por diversos países da Comunidade Europeia, tais quais a França, a Bélgica e a Holanda.

Com efeito, estes países não tributavam os lucros auferidos por subsidiárias no exterior controladas por empresas neles sediadas. Os lucros distribuídos por tais subsidiárias às suas controladoras também não eram tributados ${ }^{297}$. As regras de preços de transferência aplicáveis às exportações das controladoras para as subsidiárias no exterior eram tão benéficas quanto as regras americanas para a alocação dos lucros entre as produtoras americanas e as suas subsidiárias DISC.

Isso permitia que as empresas francesas, belgas e holandesas constituíssem subsidiárias em paraísos fiscais que não tributam a renda e realizassem todas as suas operações de exportação por meio destas subsidiárias. Uma vez que as regras de preços de transferência destes países permitiam que parcela substancial dos lucros destas exportações fosse alocada nas subsidiárias no paraíso fiscal, o resultado era a não tributação desta parcela dos lucros ${ }^{298}$.

Como os EUA adotavam regras de tributação universal, aplicando inclusive as regras CFC constantes da Subpart F do Internal Revenue Code às subsidiárias em paraísos fiscais $^{299}$, a estrutura de exportações adotada pelas empresas francesas, belgas e holandesas, que viabilizava a não tributação de parte dos lucros auferidos nas exportações por estas empresas, não podia ser utilizada pelas empresas americanas.

\footnotetext{
${ }^{297} \mathrm{Ou}$ apenas pequena parcela deles era tributada, como no caso da França, que tributava somente $10 \%$ dos dividendos.

${ }^{298}$ DESAI, Mihir A., HINES Jr., James R., The uneasy marriage of export incentives and the income tax, Cambridge-MA, 2000, disponível [on-line] in www.nber.org/papers/w8009 [23.10.2005], p. 19.

299 Às exportações para paraísos fiscais aplicam-se as base company rules, que obrigam que os lucros das subsidiárias sejam reconhecidos logo que auferidos. AVI-YONAH, Reuven S., International Tax as International Law: An Analysis of the International Tax Regime, New York, Cambridge University Press, 2007, p. 137.
} 
Assim, na visão dos EUA, as regras DISC apenas replicavam os efeitos dos regimes territoriais, sem, que fosse necessária a utilização de paraísos fiscais para a realização das operações ${ }^{300}$.

A Comunidade Europeia respondeu aos argumentos dos EUA expondo que os regimes territoriais não eram nada mais que o método eleito por alguns países europeus para evitar a bitributação. Enquanto os EUA optavam por tributar a renda universal de seus residentes e outorgar um crédito para o imposto pago no exterior, alguns países europeus preferiam simplesmente isentar os rendimentos estrangeiros da tributação. Sendo um método para eliminar a bitributação reconhecido pela OCDE, a isenção dos rendimentos auferidos no exterior não deveria ser considerada um subsídio à luz do GATT.

Ademais, a Comunidade Europeia argumentou que as regras de preços de transferência adotada pelos mencionados países não eram mais benéficas que as regras adotadas pelos EUA.

Por fim, a Comunidade Europeia salientou que, ainda que os regimes territoriais de alguns países possam ser considerados subsídios, eles não justificam a adoção das regras DISC pelos EUA, que têm de fazer valer o seu compromisso de não subsidiar as exportações perante todos os Estados Membros, inclusive aqueles que tributam a renda universal de suas empresas e não possuem regime similar ao DISC.

Não obstante os argumentos da Comunidade Europeia, os Estados Unidos contestaram os regimes territoriais da França, da Holanda e da Bélgica sob o artigo XVI:4 do GATT nos casos Income Tax Practices Maintained by France ${ }^{301}$, Income Tax Practices Maintained by Belgium ${ }^{302}$ e Income Tax Practices Maintained by The Netherlands ${ }^{303}$.

Em novembro de 1976, os painéis do GATT concluíram que as regras DISC violavam o acordo e apontaram que algumas características dos regimes territoriais também seriam contrárias ao artigo XVI do $\mathrm{GATT}^{304}$. O passo seguinte em um processo de

\footnotetext{
${ }^{300}$ Relatório do Painel em United States - Tax Legislation (DISC), L/4422-23S/98, parágrafo 41, p. 6.

${ }^{301} \mathrm{~L} / 4423-23 \mathrm{~S} / 114$.

${ }^{302} \mathrm{~L} / 4424-23 \mathrm{~S} / 127$.

${ }^{303} \mathrm{~L} / 4425-23 \mathrm{~S} / 137$

304 BRAUNER, Yariv, Direito do comércio internacional e acordos tributários, Trad. Port. Gustavo Gonçalves Vettori, in Direito Tributário Atual nº 23, São Paulo, Dialética, 2009.
} 
solução de controvérsias àquela época seria a aceitação, ou não, do resultado dos painéis pelo Conselho do GATT $^{305}$.

Todavia, não houve unanimidade e os EUA e a Comunidade Europeia chegaram a um impasse: os EUA estavam dispostos a aceitar as conclusões sobre as DISC apenas se as conclusões sobre os regimes territoriais também fossem adotadas. Os países europeus, por seu turno, apenas estavam dispostos a aceitar as conclusões contra as DISC $^{306}$.

Houve um hiato de quase cinco anos para a decisão do Conselho, período no qual se constatou forte oposição interna nos EUA ao regime das DISC. Também neste período, as negociações do Código de Subsídios na Rodada de Tóquio pareciam resolver a disputa.

O Código explicitamente incluía diferimentos como subsídios, implicando a ilegalidade do regime DISC, e afirmava a importância de usarem-se preços arm's length nas transferências entre partes ligadas ${ }^{307}$, o que impediria que esquemas de exportação para subsidiárias em paraísos fiscais reduzisse a tributação dos lucros dos exportadores residentes em países territoriais.

Em 1981, as soluções dos painéis foram adotadas pelo Conselho, sujeitas a um Entendimento, no qual se determinou que: (i) os países não são obrigados a tributar os processos econômicos que ocorram fora do seu território; (ii) os preços arm's length devem ser seguidos na alocação da renda entre partes ligadas; e (iii) o GATT não proíbe medidas para evitar a bitributação de renda de fonte estrangeira ${ }^{308}$.

Os resultados do caso DISC e deste Entendimento foram a semente da nota de rodapé 59 do ASMC, que traz três regras relevantes para determinar se medidas de tributação da renda são consideradas subsídios.

A primeira delas visa a lidar com a questão do diferimento discutida no caso DISC. Sobre esse assunto, a nota de rodapé aponta que "os Membros reconhecem que o

305 DALY, Michael, The WTO and direct taxation, 2005, disponível [on line] in http://www.wto.org/english/res_e/booksp_e/discussion_papers9_e.pdf [23-10-2010], p. 5.

\footnotetext{
${ }^{306}$ Idem, ibidem, p. 5.

${ }^{307}$ Idem, ibidem, p. 5.

${ }^{308}$ Idem, ibidem, pp. 5-6.
} 
diferimento poderá não constituir subsídio à exportação quando, por exemplo, são percebidos os juros adequados." Ou seja, o diferimento do pagamento do imposto de renda não será considerado subsídio se for atrelado a taxas de juros de mercado. Se não o for, será um subsídio, conforme decidiu o Painel no caso DISC.

As outras duas regras visam a lidar com a aceitação dos regimes territoriais europeus como método para evitar a bitributação, desde que tais regimes sejam aplicados em conjunto com adequadas regras de preços de transferência nas exportações ${ }^{309}$. Assim, a Nota de Rodapé $\mathrm{n}^{\circ} 59$ indica que: “O parágrafo (e) [do Anexo I do ASMC] não tem por finalidade impedir um Membro de tomar medidas para evitar dupla tributação sobre ganhos de fonte situada no estrangeiro por suas empresas ou pelas empresas de outro Membro" ${ }^{310}$; e

(ii) Os Membros reafirmam o princípio segundo o qual os preços de bens praticados em transações entre empresas exportadoras e compradoras estrangeiras controlados pelas primeiras, ou ambos sob o mesmo controle, devem, para fins tributários, ser os mesmos que se praticariam entre empresas independentes umas das outras em condições de livre concorrência. Qualquer Membro pode chamar a atenção de outro para práticas administrativas ou outras que contradigam esse princípio e que resultem em expressiva economia em impostos direitos aplicáveis a transações de exportação. Em tais

\footnotetext{
${ }^{309}$ DESAI, Mihir A., HINES Jr., James R., The uneasy marriage of export incentives and the income tax, Cambridge-MA, 2000, disponível [on-line] in www.nber.org/papers/w8009 [23.10.2005], p. 19

${ }^{310}$ Avi-Yonah e Slemrod salientam que a parte da nota de rodapé 59 ao item (e) do Anexo I do ASMC, que determina que as disposições do item (e) não se prestam a limitar um Estado membro a adotar medidas para evitar a bitributação de renda advinda de fonte estrangeira, foi adicionada justamente para excluir questionamentos quanto aos regimes territoriais adotados pelos países europeus. Contudo, os autores questionam se um regime de isenção que não leve em conta se o rendimento foi, ou não, tributado no país da fonte pode ser considerado como uma "medida para evitar a bitributação". Assim, sob este aspecto, regimes territoriais que não vinculassem a isenção à efetiva tributação pelo país da fonte (subject-to-tax clauses) seriam reputados como subsídios. AVI-YONAH, Reuvem S., SLEMROD, Joel, (How) should trade agreements deal with income tax issues?, disponível [on line] in www.law.umich.edu/centersandprograms/olin/papers.htm $\quad$ [=http://papers.ssrn.om/abstract=285345] [23.10.2005], p. 22. Este entendimento, contudo, não é aceito por outros autores, como Foltyn e Ureta. FOLTYN, Olga, The exemption method and fictitious tax credit as a prohibited subsidy under WTO law, in J. Herdin-Winter, I. Hofbauer, The relevance of WTO law for tax matters, Wien, Linde, 2006, p. 385. URETA, Santiago Solórzano, National report Mexico, in in WTO and Direct Taxation, LANG, Michael, HERDIN, Judith, HOFBAUER, Inês (coord.) Kluwer Law International, 2005, p. 491
} 
circunstâncias, os Membros tentarão normalmente resolver suas diferenças pelas vias previstas em tratados bilaterais existentes em matéria fiscal ou por meio de outros mecanismos internacionais específicos, sem prejuízo dos direitos e das obrigações que para os Membros derivam do GATT 1994, entre os quais o direito de consulta criado no período precedente.

Saliente-se, ainda, que a Nota de Rodapé $\mathrm{n}^{\circ} 5$ ao artigo 1(a) do ASMC determina que "aquelas medidas que estejam indicadas no ANEXO I como não caracterizadoras de subsídios à exportação não serão proibidas por este Artigo ou nenhum outro deste Acordo". Uma vez que a Nota de Rodapé n 59 encontra-se no Anexo I do ASMC, as medidas de tributação da renda que esta nota indica que não são subsídios estão fora da aplicação do acordo.

\section{III.4.2. FSC/ETI}

Os parâmetros nos quais o GATT aceitou os regimes territoriais europeus serviu como base para as regras FSC (Foreign Sales Corporations) adotadas pelos EUA em $1984^{311}$ em substituição ao regime DISC.

Tratava-se de um sistema de isenção parcial para a tributação de rendimentos das atividades relacionadas a exportações desempenhadas fora dos EUA, que seguiu os mesmos propósitos do regime DISC, tentando ajustá-lo à linguagem da opinião do conselho que permitiu a não-tributação da renda extraterritorial ${ }^{312}$.

Em linhas gerais, o regime FSC permitia que empresas americanas estabelecessem subsidiárias em paraísos fiscais e canalizassem as suas exportações por meio destas subsidiárias.

311 DALY, Michael, The WTO and direct taxation, 2005, disponível [on line] in http://www.wto.org/english/res_e/booksp_e/discussion_papers9_e.pdf [23-10-2010], p. 6.

312 BRAUNER, Yariv, Direito do comércio internacional e acordos tributários, Trad. Port. Gustavo Gonçalves Vettori, in Direito Tributário Atual nº 23, São Paulo, Dialética, 2009. 
Regras formulares diferenciadas de preços de transferência aplicavam-se na alocação do lucro das exportações entre a controladora americana e a sua subsidiária FSC. Tais regras permitiam que parte do lucro fosse alocada no exterior ${ }^{313}$.

O lucro alocado na FSC, por seu turno, era excluído da tributação universal dos Estados Unidos. Em primeiro lugar, os lucros não distribuídos da FSC eram excluídos da aplicação das regras CFC (anti-diferimento) previstas na Subpart-F do IRC. Em segundo lugar, ainda que estes lucros fossem distribuídos pela FSC como dividendos para a sua controladora americana, não haveria tributação da controladora americana, pois tais dividendos eram isentos.

Apenas os lucros caracterizados como foreign trade income da subsidiária (FSC) no exterior poderiam se beneficiar deste tratamento. Estes lucros eram aqueles que decorriam da venda de bens produzidos nos EUA, vendidos fora dos EUA e que não tivessem mais de $50 \%$ do seu valor de mercado atribuível a bens importados.

Os lucros não qualificados como foreign trade income auferidos por subsidiárias no exterior de empresas estavam sujeitos às regras de tributação universal e CFC americanas. Ou seja, tais lucros seriam tributados quando distribuídos às controladoras americanas e ainda estavam sujeitos às regras de transparência da Subpart-F do IRC, cuja aplicação poderia implicar a tributação dos lucros da subsidiária no exterior mesmo antes de sua distribuição. Os lucros qualificados como foreign trade income, por seu turno, não estavam sujeitos à referida tributação.

A União Europeia esperou 13 anos até contestar este segundo regime em novembro de 1997, contestação esta seguida de requerimento oficial, em $1^{\circ}$ de julho de 1998, para um painel de solução de controvérsias, baseado nas violações dos artigos 1.1, 3.1(a) e (b) e da lista ilustrativa do $\mathrm{ASMC}^{314}$.

Os argumentos da União Europeia podem ser resumidos da seguinte forma ${ }^{315}$ :

\footnotetext{
${ }^{313}$ DESAI, Mihir A., HINES Jr., James R., The uneasy marriage of export incentives and the income tax, Cambridge-MA, 2000, disponível [on-line] in www.nber.org/papers/w8009 [23.10.2005], pp. 4-7.

314 BRAUNER, Yariv, Direito do comércio internacional e acordos tributários, Trad. Port. Gustavo Gonçalves Vettori, in Direito Tributário Atual no 23, São Paulo, Dialética, 2009.

${ }^{315}$ Relatório do Painel em United States - Tax Treatment for "Foreign Sales Corporations", WT/DS108/R e Relatório do Órgão de Apelação em United States - Tax Treatment for "Foreign Sales Corporations", WT/DS108/AB/R. McDANIEL, Paul R., Trade agreements and income taxation: interactions, conflicts, and
} 
(i) A isenção dos lucros das FSC qualificados como foreign trade income da aplicação das regras CFC constantes da Subpart-F do IRC, bem como a isenção da tributação da controladora pelos dividendos distribuídos pelas FSC em decorrência destes lucros, eram um subsídio.

(ii) As regras formulares de preços de transferência aplicadas às transações entre as FSC e suas controladoras americanas permitiam que parte dos lucros de exportações fossem alocados nas FSC e gozassem do benefício apontado em (i) supra.

(iii) A qualificação do foreign trade income era vinculada à realização de exportação. Desta forma o subsídio em tela é um subsídio proibido nos termos do artigo 3(a) do ASMC.

(iv) A exigência, para a qualificação do rendimento como foreign trade income, de que os bens exportados tivessem ao menos $50 \%$ de seu valor de mercado atribuíveis a bens de origem americana é uma regra de conteúdo nacional que viola o artigo 3(b) do ASMC.

Os Estados unidos, por seu turno, defendiam que:

(i) O regime FSC não era um subsídio, pois segundo a nota de rodapé 59 do ASMC a renda decorrente de atividade econômica exercida fora do país não precisa ser tributada (i.e., regime territorial). A renda que a legislação estadunidense permitia que fosse alocada às FSC era renda decorrente de atividade econômica exercida no exterior. Assim, a decisão de não tributá-la não era um subsídio.

(ii) A alocação dos rendimentos às FSC aproximava-se do padrão arm's length e, portanto era permitida pela nota de rodapé 59 do ASMC.

(iii) Como nenhum acordo sob a OMC exige que um país tribute a renda universal de seus residentes, a exclusão da tributação americana dos 
lucros alocados nas FSC não representa qualquer tipo de renúncia fiscal e não deve ser considerada, assim, um subsídio.

(iv) A exigência, para a qualificação do rendimento como foreign trade income, de que os bens vendidos não tivessem mais de $50 \%$ do seu valor constituído por bens importados, não era uma regra de conteúdo nacional sob o artigo 3(b) do ASMC pois a regra apenas exigia que $50 \%$ do valor do bem fosse agregado nos EUA, não necessariamente com o uso de produtos de origem americana. Assim, ainda que todos os insumos utilizados em um produto fossem importados, o lucro na venda deste produto ainda poderia ser qualificado como foreign trade income se $50 \%$ do seu valor correspondesse, por exemplo, a mão de obra ou intangíveis agregados nos EUA.

O painel emitiu um parecer final contra os EUA em 8 de outubro de 1999, entendendo que as regras FSC constituíam um subsídio às exportações inconsistente com o $\mathrm{ASMC}^{316}$. A apelação dos EUA foi rejeitada pelo Órgão de Apelação em 24 de fevereiro de $2000^{317}$.

Em resposta, os EUA adotaram um terceiro regime, o regime ETI, que foi desenvolvido para conformar-se com a decisão e que possuía consequências similares ao regime $\mathrm{FSC}^{318}$. Ele anunciava incorporar (os agora permitidos) aspectos territoriais no regime de tributação universal dos $\mathrm{EUA}^{319}$. A União Europeia prontamente respondeu, arguindo que as regras ETI não estavam de acordo com a decisão do caso FSC $^{320}$. Foi aberto um painel que decidiu contra os EUA em 20 de agosto de 2001. Os EUA apelarem, mas a apelação foi rejeitada em todos os seus argumentos pelo Órgão de Apelação, em 14 de janeiro de $2002^{321}$.

\footnotetext{
316 BRAUNER, Yariv, Direito do comércio internacional e acordos tributários, Trad. Port. Gustavo Gonçalves Vettori, in Direito Tributário Atual $n^{\circ}$ 23, São Paulo, Dialética, 2009.

${ }^{317}$ Relatório do Órgão de Apelação em United States - Tax Treatment for "Foreign Sales Corporations", WT/DS108/AB/R, parágrafo 179.

${ }^{318}$ BRAUNER, Yariv, op. cit.

319 Os EUA declararam que o regime ETI não era apenas um substituto para o regime FSC, mas uma efetiva reforma do sistema tributário americano para incluir aspectos territoriais.

${ }^{320}$ Idem, ibidem.

${ }^{321}$ Idem, ibidem.
} 
Os EUA, então, deram por perdida a batalha, mas a não revogação do regime pelo Congresso americano levou à retaliação pela União Europeia em $1^{\circ}$ de março de 2004. Finalmente, os EUA assumiram a derrota e revogaram o sistema em $2005^{322}$.

No julgamento do caso FSC, o Painel primeiramente examinou se as regras constituiriam receitas renunciadas que, não fossem por essas regras, seriam devidas. $\mathrm{O}$ Painel rejeitou os argumentos dos EUA que sustentavam que, se as regras da OMC não exigem que um Membro tributem determinado tipo de rendimentos (i.e., rendimentos auferidos no exterior), a isenção destes rendimentos não pode ser considerada um subsídio.

$\mathrm{Na}$ análise deste ponto, o Painel entendeu que, uma vez que não há uma regra teórica para identificar os tributos "otherwise due", é necessário comparar o tratamento tributário aplicável no caso específico com o regime tributário geralmente aplicável aos contribuintes. Em outras palavras, o Painel utilizou o teste "but-for" para determinar se haveria a renúncia de receitas, indagando se o contribuinte teria pagado um montante maior de tributos se não houvesse a isenção das $\mathrm{FSC}^{323}$.

Nesse sentido, o Painel notou que os EUA geralmente aplicam um regime de tributação universal dos rendimentos de seus residentes. Isto é, em regra são tributáveis nos EUA os rendimentos auferidos por um residente americano, independente de estes rendimentos derivarem de fontes nos EUA ou no exterior. Para evitar a bitributação dos rendimentos de fonte no exterior, a legislação dos EUA outorga um crédito referente ao tributo pago no país da fonte ${ }^{324}$.

O Painel apontou, ainda, que nada impediria que os EUA tivessem adotado um sistema territorial de tributação, pelo qual os rendimentos de fonte estrangeira auferidos por residentes nos EUA estariam isentos de tributação americana ${ }^{325}$.

No entanto, os EUA não estariam livres para adotar o sistema universal de uma maneira geral e, paralelamente, excluir alguns rendimentos desta regra ${ }^{326}$ baseando-se no

\footnotetext{
322 BRAUNER, Yariv, Direito do comércio internacional e acordos tributários, Trad. Port. Gustavo Gonçalves Vettori, in Direito Tributário Atual $n^{\circ}$ 23, São Paulo, Dialética, 2009. O regime ETI foi revogado em $1^{\circ}$ de janeiro de 2005 pelo American Jobs Creation Act.

${ }^{323}$ McDANIEL, Paul R., Trade agreements and income taxation: interactions, conflicts, and resolutions, Boston, 2004, disponível [on line] in http://www.un.org/esa/ffd/aconf198-11.pdf [05.11.2005], p. 12.

${ }^{324}$ Idem, ibidem, p. 12.

${ }^{325}$ Idem, ibidem, p.12.
} 
argumento de que outros países adotam o sistema territorial. Os EUA não poderiam, na visão do Painel, afirmar que o seu sistema geral de tributação cria um impacto adverso aos seus exportadores em relação aos de outros países e, assim, justificar um subsídio à exportação como uma medida para eliminar uma desvantagem aos seus exportadores criada pelo seu próprio sistema ${ }^{327}$.

Esta tática, entendeu o Painel, não seria diferente da adoção de um tributo sobre a renda de $75 \%$ e, paralelamente, da adoção da alíquota de $25 \%$ para os exportadores com base no argumento de que outros países tributam a renda à alíquota (geral) de apenas $25 \%{ }^{328}$.

Desta maneira, o Painel concluiu que a isenção dos lucros das FSC era um subsídio. Uma vez que tais lucros somente seriam isentos se decorressem de atividades de exportação, o subsídio seria proibido nos termos do artigo 3(1)(a) do ASMC.

Por fim, o Painel entendeu que, como tinha considerado o regime FSC um subsídio à exportação à luz do artigo 3(1)(a) do ASMC, a questão da regra de conteúdo nacional, atinente à aplicação do artigo 3(1)(b), não precisaria ser analisada ${ }^{329}$.

O Órgão de Apelação, de uma maneira geral, confirmou o entendimento do Painel. Vale apontar, contudo, que este órgão afirmou em seu relatório que o teste aplicado pelo Painel para verificar a existência de um subsídio não necessariamente seria apropriado em todos os casos.

\footnotetext{
${ }^{326}$ É interessante notar que, sob esta ótica, diversos sistemas mistos adotados por países europeus (cf. McDANIEL, Paul R., The impact of trade agreements on tax systems, in INTERTAX, v. 30, issue 5, 2002, p. 167), que são territoriais em alguns aspectos e universais em outros, poderiam ser considerados subsídios em relação aos rendimentos tributados territorialmente. Todavia, diferentemente das regras FSC, os regimes mistos não vinculam a territorialidade às atividades de exportação. Por esta razão, os aspectos territoriais de regimes tipicamente mistos seriam no máximo considerados subsídios acionáveis. Ademais, é possível sustentar que a tributação universal adotada pelos regimes mistos presta-se apenas a evitar que a renda passiva de multinacionais e residentes seja represada no exterior, com diferimento prolongado da tributação. Assim, tais regimes poderiam justificar-se como simples medidas para evitar a elisão e evasão.

${ }^{327}$ McDANIEL, Paul R., op. cit, p. 12.

${ }^{328}$ Relatório do Painel em United States - Tax Treatment for "Foreign Sales Corporations, WT/DS108/R, parágrafos 7.122 , p. 282.

${ }^{329}$ Relatório do Painel em United States - Tax Treatment for "Foreign Sales Corporations, WT/DS108/R, parágrafos 7.131 e 7.132 , p. 284.
} 
Dessa maneira, o Órgão de Apelação buscou, para a análise do subsidio, determinar um "parâmetro normativo", que seria o padrão prevalecente da legislação do Estado Membro ${ }^{330}$.

Normas tributárias específicas deveriam ser testadas em relação ao sistema tributário geralmente aplicável do próprio país. Os acordos sob a OMC não obrigariam um Membro a tributar rendimentos de uma ou outra maneira. Todavia, uma vez que ele tenha formatado o seu sistema parâmetro de uma maneira específica, desvios deste parâmetro podem configurar subvenções tributárias, as quais, por seu turno, podem constituir subsídios proibidos ou acionáveis sob o ASMC.

\section{III.4.3 Outros casos}

Em 1998, em resposta ao ataque da união Europeia ao regime FSC, os Estados Unidos iniciaram procedimentos de consulta em relação a determinadas regras de tributação da renda adotadas pela França, Irlanda, Grécia, Holanda e Bélgica que supostamente violariam o ASMC. Não foram estabelecidos painéis em nenhum desses $\operatorname{casos}^{331}$. Os casos são os seguintes:

(i) Procedimento de consulta contra a França em relação a regras que possibilitam a dedução de determinados custos pré-operacionais relacionados com a estruturação de atividades no exterior. Este mesmo caso envolve regras que permitem que negócios franceses façam uma reserva especial em sua contabilidade tributária que corresponde ao risco relacionado a vendas a crédito para exportação.

(ii) Procedimento de consulta contra a Irlanda referente à tributação de "special trading houses" que, de acordo com os EUA, sujeitam-se a tributação reduzida da renda decorrente da exportação de bens.

\footnotetext{
${ }^{330}$ Relatório do Órgão de Apelação em United States - Tax Treatment for "Foreign Sales Corporations, WT/DS108/AB/R, parágrafo 90, p. 31.

${ }^{331}$ MONROY, Antonio Grimaldo, The relevance of WTO Law for international tax Law, in J. Herdin-Winter, I. Hofbauer (org.), The relevance of WTO law for tax matters, Wien, Linde, 2006, pp. 30-31.
} 
(iii) Procedimento de consulta contra a Grécia referente à possibilidade de companhias exportadoras obterem benefício tributário correspondente a percentual de sua renda decorrente de exportações.

(iv) Procedimento de consulta contra a Holanda, referente à possibilidade de se declarar a renda decorrente de exportações como uma reserva.

(v) Procedimento de consulta contra a Bélgica, referente a uma dedução especial que era dada a companhias que designassem uma pessoa para supervisionar as usas atividades de exportação.

\section{III.5. Impostos indiretos e diretos}

Neste tópico, faremos algumas considerações sobre tratamento outorgado pelo GATT e pelo ASMC aos subsídios veiculados por tributos indiretos, comparando-o com aquele dado aos tributos diretos.

A nota ao Artigo XVI do GATT determina que "A isenção em favor de um produto exportado, dos direitos ou taxas que atingem o produto similar quando este é destinado a consumo interno, ou a emissão, desses direitos ou taxas em quantidade que não excedam aqueles que eram devidos, não serão considerados como uma subvenção."

Por seu turno, a nota de rodapé 1 do ASMC, inserida no artigo 1(a)(1)(ii), esclarece que "de acordo com as disposições do Artigo XVI do GATT 1994 (nota do Artigo XVI) e de acordo com os anexos I a III deste acordo, não serão consideradas como subsídios as isenções em favor de produtos destinados a exportação, de impostos ou taxas habitualmente aplicados sobre o produto similar quando destinado ao consumo interno, nem a remissão de tais impostos ou taxas em valor que não exceda os totais devidos ou abonados".

Por fim, o item (g) do Anexo I ao ASMC prevê que se consideram subsídios à exportação "a isenção ou remissão de impostos indiretos sobre a produção e a 
distribuição de produtos exportados, além daqueles aplicados sobre a produção e a distribuição de produto similar vendido para consumo interno."

Todos estes dispositivos visam a viabilizar, no âmbito do GATT e do ASMC, os chamados border tax adjustments. Trata-se da aplicação do princípio do destino em relação aos tributos indiretos.

O Relatório do Working Party on Border Tax Adjustments ${ }^{332}$, adotado em 1970, define estes ajustes como "medidas tributárias que implementam, em todo ou em parte, o princípio do destino (i.e., que permite que produtos exportados sejam isentados de alguns ou todos os tributos cobrados pelo país exportador sobre produtos nacionais similares vendidos a consumidores no mercado interno e que permite que, sobre produtos importados vendidos a consumidores, incidam alguns ou todos os tributos cobrados pelo país importados sobre produtos similares nacionais)"

Assim, o que os dispositivos do GATT e do ASMC citados acima permitem é que:

(i) Nas importações, um Estado Membro faça incidir sobre os produtos importados os mesmos tributos que incidem sobre a venda de produtos nacionais similares. Este tratamento é permitido pelo artigo III do GATT.

(ii) Nas exportações, um Estado Membro isente ${ }^{333}$ dos tributos indiretos os produtos exportados.

A lógica da adoção do princípio do destino é que todos os produtos consumidos em um determinado mercado serão tributados pelos mesmos tributos indiretos - i.e., apenas os tributos indiretos cobrados pelo Estado importador, desde que todos os Estados envolvidos nas trocas internacionais adotem o princípio do destino ${ }^{334}$.

\footnotetext{
${ }^{332}$ Border Tax Adjustments - Report of the Working Party, adotado em 2 de dezembro de 1970, L/3464.

${ }^{333}$ No caso de um imposto sobre o valor agregado, o tributo incidente nas etapas anteriores da cadeia produtiva pode ser devolvido sem que tal devolução seja considerada um subsídio.

${ }^{334}$ LEJEUNE, Ine, DAOU-AZZI, Jeanine, POWELL, Mark, The balance hás shifted to consumption taxes lessons learned and Best practices for VAT, in LANG, Michael, MELZ, Peter, KRISTOFFERSSON, Eleonor (Orgs.), Value added tax and direct taxation: similarities and differences, Amsterdam, IBFD, 2009, p. 86
} 
Esses ajustes, contudo, somente podem ser realizados em relação aos tributos indiretos, ou seja, aqueles que incidem sobre vendas, consumo, faturamento, valor acrescido etc.

Não há a autorização para a realização de qualquer ajuste em relação aos tributos diretos, categoria na qual se incluem os tributos sobre a renda.

Ou seja, o imposto de renda cobrado de um produtor nacional não pode ser isentado sobre a parcela dos lucros deste produtor decorrente das suas atividades de exportação. Como vimos nos tópicos anteriores, tal isenção seria considerada um subsídio proibido sob o artigo 3 do ASMC.

Da mesma maneira, o Estado importador não poderia cobrar, nas importações, o imposto de renda sobre a parcela do lucro do exportador estrangeiro auferida com a venda daqueles produtos importados. Tal imposto, além de impraticável (i.e., o estado importador não teria como determinar qual é o lucro do produtor estrangeiro atribuível às vendas do produto importado), provavelmente seria considerado discriminatório à luz do artigo III do GATT, pois não seria cobrado de maneira similar sobre os produtos nacionais vendidos no mercado do Estado em questão ${ }^{335}$.

Nesses termos, a aplicação do princípio do destino para os tributos diretos é inviável e vedada.

É inviável porque a incidência jurídica destes tributos dá-se sobre pessoas e não sobre transações com produtos. Assim, apesar de ser possível isentar a renda dos exportadores, não é possível cobrar o imposto de renda nas importações. Se todos os Estados simplesmente isentassem a renda dos exportadores e não aplicassem um imposto correspondente nas importações, a renda mundial decorrente das exportações não seria tributada, enquanto a renda decorrente das vendas no mercado interno seria. Este não

\footnotetext{
335 Apesar de o imposto de renda incidir sobre os lucros dos produtores do Estado importador, ele não incidira da mesma maneira que esta hipotética cobrança de imposto de renda nas importações, motivo pelo qual tal cobrança provavelmente não se sustentaria à luz do atual artigo III do GATT.
} 
parece ser um resultado desejável, tanto sob o ponto de financiamento dos Estados ${ }^{336}$, quanto sob a ótica econômica da liberalização do comércio internacional ${ }^{337}$.

É vedada porque o artigo 3 do ASMC e os artigos III e XVI do GATT não permitem ajustes deste tipo.

A permissão para a aplicação do princípio do destino em relação aos impostos indiretos e vedação para os impostos diretos baseia-se na própria lógica que tradicionalmente fundamenta a distinção entre estes dois tipos de tributos.

Esta tradicional distinção entre tributos diretos e indiretos era baseada na crença de que há uma diferença em quem suporta o ônus econômico de cada um destes tributos $^{338}$.

Em relação aos tributos diretos, que têm como fato gerador a renda auferida por pessoas físicas ou jurídicas, ou a propriedade detida por estas pessoas, acreditava-se que o contribuinte (i.e., a pessoa que tem a obrigação legal de pagar o tributo) era quem suportava o ônus econômico do tributo.

Por outro lado, em relação aos tributos indiretos, que incidem sobre transações de produtos ou serviços, acreditava-se que, apesar de os produtores ou vendedores terem a obrigação legal de pagar o tributo, não eram eles que suportavam o seu ônus econômico, pois o valor do tributo seria repassado para o consumidor final no preço dos produtos ou serviços transacionados.

Com base neste raciocínio, uma vez que os tributos indiretos seriam suportados pelos consumidores finais dos produtos, a aplicação do princípio do destino permitiria que apenas o Estado de tais consumidores cobrassem tais tributos.

\footnotetext{
${ }^{336}$ Boa parte da base tributável seria desnecessariamente erodida.

${ }^{337}$ Haveria um estímulo às trocas internacionais em detrimento das vendas no mercado interno, podendo gerar uma alocação subótima destas trocas, contrariando a própria teoria das vantagens comparativas de David Ricardo.

338 VIMERCATE, Paolo de'Capitani di, VAT/GST and direct taxes: how can we distinguish them?, in LANG, Michael, MELZ, Peter, KRISTOFFERSSON, Eleonor (orgs.), Value added tax and direct taxation, Amsterdam, IBFD, 2009, p. 155.
} 
Por outro lado, sendo os tributos sobre a renda (diretos) suportados pelos produtores, e não pelos consumidores, justificar-se-ia a cobrança deste tributo pelo Estado no qual se situa o produtor (exportador) e não pelo Estado importador.

No entanto, a teoria econômica moderna mostra que esta divisão entre tributos diretos e indiretos não se justifica, pois, o ônus econômico de ambos pode ser dividido entre consumidores, produtores, detentores do capital e empregados, dependo das condições de oferta e demanda do mercado ${ }^{339}$.

Note-se que esta distinção entre os tributos diretos e indiretos no que tange à aplicação do princípio do destino foi um dos motivos ${ }^{340}$ pelos quais os EUA buscaram reduzir a tributação da renda de seus exportadores por meio das regras DICS e FSC ${ }^{341}$.

Para compreender esta afirmação, é necessário constatar uma diferença fundamental entre as políticas tributárias dos EUA e dos países europeus. Enquanto as receitas do imposto de renda exercem um papel predominante no financiamento dos EUA (o que faz com que a maior parte da carga tributária deste país se concentre no imposto de renda), nos países europeus o imposto sobre o valor agregado (IVA) também representa ao lado do imposto de renda - fonte significativa de receitas públicas, o que permite que a carga tributária desses países seja dividida entre estes dois impostos principais ${ }^{342}$.

O resultado dessa diferença de políticas é o seguinte ${ }^{343}$ :

(i) Os produtos exportados pelos países europeus eram isentados do IVA em decorrência da aplicação do princípio do destino. Os produtores europeus, por seu turno, pagavam imposto de renda a alíquotas moderadas. Quando os produtos europeus entravam no mercado

\footnotetext{
${ }^{339}$ ENGLISH, Joachim, VAT/GST and direct taxes: different purposes, in LANG, Michael, MELZ, Peter, KRISTOFFERSSON, Eleonor (orgs.), Value added tax and direct taxation, Amsterdam, IBFD, 2009, pp. 12. SCHÖN, Wolfgang, World Trade Organization Law and Tax Law, in BIFD v. 58, 2004, p. 291. VIMERCATE, Paolo de'Capitani di, VAT/GST and direct taxes: how can we distinguish them?, in LANG, Michael, MELZ, Peter, KRISTOFFERSSON, Eleonor (orgs.), Value added tax and direct taxation, Amsterdam, IBFD, 2009, p. 155.

${ }^{340}$ Em conjunto com a já mencionada diferença entre o regime universal dos EUA e os regimes territoriais dos países europeus.

341 DALY, Michael, The WTO and direct taxation, 2005, disponível [on line] in http://www.wto.org/english/res_e/booksp_e/discussion_papers9_e.pdf [23-10-2010], p. 9, nota de rodapé 23.

${ }^{342}$ Em conjunto com a já mencionada diferença entre o regime universal dos EUA e os regimes territoriais dos países europeus.

${ }^{343}$ SCHÖN, Wolfgang, op. cit., p. 291.
} 
americano, os EUA não impunham um tributo indireto similar ao IVA $^{344}$ sobre estes produtos em decorrência da ausência de um tributo deste tipo nos Estados Unidos.

(ii) Os produtos exportados pelos EUA não sofriam qualquer incidência de tributos indiretos. Todavia, os produtores americanos estavam sujeitos ao imposto de renda dos EUA. Quando os produtos americanos entravam no mercado dos países europeus, estavam sujeitos à incidência do IVA.

Uma vez que, seguindo a teoria econômica moderna, tanto o imposto de renda quanto o IVA afetam o preço dos produtos, a diferença entre a opção de financiamento dos EUA (maior carga de imposto de renda e menor carga de impostos indiretos) e dos países europeus (carga divida entre o imposto de renda e o IVA), atrelada à possibilidade de aplicação do princípio do destino ao IVA e impossibilidade em relação ao imposto de renda, fazia com que os produtos americanos chegassem em condições desfavorecidas no mercado europeu e com que os produtos europeus chegassem em condições vantajosas no mercado americano ${ }^{345}$.

Contudo, dentro da sistemática do ASMC este argumento não poderia ser utilizado para justificar a isenção americana aplicável aos lucros de exportação de seus produtores, pois: (i) a aplicação do princípio do destino somente é permitida para os tributos indiretos; e (ii) a aplicação das regras de subsídios toma o sistema tributário do país como parâmetro ${ }^{346}$ para a identificação de subvenções tributárias, o que impede que desvios deste parâmetro sejam adotados para corrigir desvantagens que ele possa gerar.

Dessa forma, ainda que as diferenças dos sistemas tributários dos EUA e dos países europeus possam gerar distorções no comércio entre ambos, parece que, na sistemática do GATT e do ASMC, cada país está sujeito às suas próprias decisões de política tributária $^{347}$. Nada impede que tais decisões sofram mudanças, desde que estas sejam implementadas como uma reforma geral no sistema tributário do país (e.g., adoção,

\footnotetext{
344 Os produtos importados estariam sujeitos à incidência do retail sales tax cobrado pelos estados americanos. Todavia, a alíquota deste tributo é muito baixa em comparação à alíquota do IVA cobrado pelos países europeus.

${ }^{345}$ SCHÖN, Wolfgang, World Trade Organization Law and Tax Law, in BIFD v. 58, 2004, p. 291.

${ }^{346}$ Ver tópico III.4.2 supra.

${ }^{347}$ Idem, ibidem, p. 291.
} 
pelos EUA, de um VAT em substituição ao imposto de renda), e não por meio de um subsídio específico voltado a corrigir a suposta desvantagem.

Uma justificativa que poderia ser dada para a aplicação do princípio do destino apenas aos tributos indiretos seria que estes tributos incidem sobre o consumo, enquanto os tributos diretos incidem sobre o capital ${ }^{348}$.

Faz sentido que os tributos sobre o consumo sejam cobrados no país em que ocorre o consumo, enquanto os tributos sobre o capital sejam cobrados no país de residência do detentor do capital. Assim, este raciocínio justificaria que somente os tributos sobre o consumo fossem ajustados pelo princípio do destino.

No entanto, vale notar que não há uma necessária correspondência entre a definição de tributos indiretos, dada pela Nota de Rodapé $n^{\circ} 58$ do ASMC (i.e., tributos sobre vendas, consumo, volume de negócio, valor acrescido etc.), e a definição de tributos sobre o consumo.

Tome-se o IVA como exemplo. Pela definição do ASMC ele é um tributo indireto. Todavia, uma IVA pode ou não ser um tributo sobre o consumo, dependendo da forma pela qual ele for implementado.

A este respeito, Musgrave ${ }^{349}$ aponta que a base de um IVA será:

(i) A produção nacional se os únicos créditos permitidos pelo IVA forem aqueles referentes a insumos diretamente utilizados no processo de produção. Bens de capital não dariam direito a qualquer crédito.

(ii) A renda se o IVA permitir crédito para os insumos utilizados no processo de produção e também em relação à depreciação dos bens de capital utilizados neste processo.

\footnotetext{
348 Lembre-se que, economicamente, os tributos sobre a renda incidem sobre o consumo e acréscimo patrimonial de um determinado período. Ou seja, eles tributam o consumo e o capital poupado.

${ }^{349}$ MUSGRAVE, Richard Abel, MUSGRAVE, Peggy B., Public finance in theory and practice, $4^{\mathrm{a}} \mathrm{ed}$., New York, McGraw-Hill, 1984, pp. 441-443.
} 
(iii) O consumo se o IVA permitir crédito para os insumos utilizados na produção e para os bens de capital logo no momento em que tais bens sejam adquiridos.

Ou seja, apesar de todos estes tipos de impostos sobre o valor agregado serem considerados tributos indiretos na definição do ASMC, apenas o último tipo será um tributo sobre o consumo.

Se a aplicação do princípio do destino se justifica no fato de a base do tributo ser o consumo, apenas o último tipo de IVA deveria estar sujeito às regras da nota de rodapé 1 do ASMC e da nota ao artigo XVI do GATT, que permitem a aplicação do princípio do destino.

Todavia, tendo em vista que o item (g) do Anexo I do ASMC refere-se expressamente a impostos indiretos, parece-nos que a aplicação do princípio do destino seria aceita em relação a qualquer destes IVAs.

Esta discussão não é meramente teórica, pois o Brasil efetivamente adota IVAs do tipo renda, e não do tipo consumo.

Com efeito, os contribuintes do PIS e da COFINS sujeitos à sistemática não cumulativa destas contribuições podem tomar créditos apenas da depreciação dos bens de capital que adquirirem ${ }^{350}$. Da mesma maneira, os contribuintes do ICMS somente podem tomar créditos de bens de capital à razão de $1 / 48$ do valor do bem por mês ${ }^{351}$. Todos estes tributos são aplicados pelo Brasil com base no princípio do destino.

Assim, se o princípio do destino pudesse ser aplicado apenas aos tributos sobre o consumo, haveria a possibilidade de a não tributação, pelo Brasil, do PIS, da COFINS e do ICMS nas exportações ser contestada à luz do ASMC.

Todavia, conforme já apontamos, acreditamos que as regras do ASMC não dão margem a esta interpretação.

\footnotetext{
${ }^{350}$ Conforme previsto no artigo $3^{\circ}, \S 1^{\circ}$, III, da Lei $n^{\circ} 10.833 / 03$ e artigo $3^{\circ}, \S 1^{\circ}$, III, da Lei $n^{\circ} 10.637 / 02$.

${ }^{351}$ Conforme previsto no $\$ 5^{\circ}$ do artigo 20 da Lei Complementar $n^{\circ} 87 / 96$.
} 


\section{III.6. Preços de transferência e subsídios à exportação}

Verificamos no tópico III.4.1 supra que os resultados das decisões do caso DISC e dos regimes territoriais europeus levaram à posterior adoção da Nota de Rodapé $n^{\circ}$ 59 do ASMC, que, por um lado, permite a adoção de regimes territoriais mas, por outro, exige que as exportações sejam ajustadas por métodos adequados de preços de transferência.

Quanto aos preços de transferência, a nota de rodapé estabelece que "os Membros reafirmam o princípio segundo o qual os preços de bens praticados em transações entre empresas exportadoras e compradoras estrangeiras controlados pelas primeiras, ou ambos sob o mesmo controle, devem, para fins tributários, ser os mesmos que se praticariam entre empresas independentes umas das outras em condições de livre concorrência. Qualquer Membro pode chamar a atenção de outro para práticas administrativas ou outras que contradigam esse princípio e que resultem em expressiva economia em impostos direitos aplicáveis a transações de exportação. Em tais circunstâncias, os Membros tentarão normalmente resolver suas diferenças pelas vias previstas em tratados bilaterais existentes em matéria fiscal ou por meio de outros mecanismos internacionais específicos, sem prejuízo dos direitos e das obrigações que para os Membros derivam do GATT 1994, entre os quais o direito de consulta criado no período precedente."

Vimos, no tópico II.4.2 do Capítulo II supra, que os ajustes de preços de transferência nas importações, se aplicados de forma mais gravosa que os ajustes nas exportações, poderiam ser considerados discriminatórios à luz do artigo III:4 do GATT e do Acordo TRIMS, pois agiriam como regras de conteúdo local.

A questão ora abordada é diversa. Indaga-se se ajustes de preços de transferência nas exportações que desviam do padrão arm's length e, portanto, permitem que maior parte do lucro das exportações seja alocada em subsidiárias no exterior, podem ser considerados, em si, um subsídio às exportações.

Com efeito, conforme visto no tópico III.4.1 supra, a adoção, por um determinado país, de regras de preços de transferência fora do padrão arm's length na exportação que permitem a alocação de lucros locais no exterior (doravante regras 
"benéficas" de preços de transferência nas exportações) viabiliza que empresas deste país aloquem estes lucros das exportações em subsidiárias constituídas em países de baixa tributação. Este resultado é atingido por meio da venda das mercadorias, pela controladora às subsidiárias estrangeiras, a preços inferiores ao de mercado e a subsequente revenda destas mercadorias, a preços de mercado, pelas subsidiárias ao destinatário final.

Em relação ao lucro alocado na subsidiária no exterior, há três atitudes que a legislação do país da controladora (exportadora) pode adotar:

(i) Isenção total da tributação do lucro alocado na subsidiária estrangeira, tanto no momento em que ele é auferido, quanto quando ele for distribuído à controladora na forma de dividendos. Trata-se da adoção da territorialidade estrita em relação aos lucros apurados no exterior. Este era o sistema adotado pela França e que foi contestado pelos EUA no âmbito do $\mathrm{GATT}^{352}$, conforme já apontamos no tópico III.4.1 supra.

(ii) Tributação do lucro alocado na subsidiária apenas no momento em que ele for distribuído para a controladora. Ou seja, a tributação dos lucros é diferida até o momento da distribuição, sem a aplicação de qualquer taxa de juros sobre o montante do tributo diferido ${ }^{353}$. Trata-se da adoção da tributação universal sem a aplicação de regras CFC (que determinam a transparência das subsidiárias em determinadas ocasiões).

(iii) Tributação do lucro alocado na subsidiária no momento em que ele é auferido pela subsidiária, ainda que ele não seja distribuído para a controladora. Trata-se da adoção do sistema de tributação universal com a aplicação de regras CFC. Este é o sistema atualmente adotado pelo Brasil em relação aos lucros de quaisquer controladas e coligadas no exterior, conforme estabelecido no artigo 74 da Medida Provisória

\footnotetext{
${ }^{352}$ Income Tax Practices Maintained by France, L/4423-23S/114.

${ }^{353}$ Sobre o caráter de subvenção tributária do diferimento da tributação de lucros, ver as nossas considerações em VETTORI, Gustavo Gonçalves, MALHERBE, Jacques, Deducting Interest on Equity Capital: Brazilian and Belgian Tax Rules Compared, in Studi Tributari Europei v. 1, 2010. Nesse artigo, apontamos que a tributação diferida dos lucros represados em uma jurisdição que não tributa a renda permite que estes lucros sejam aplicados e rendam juros, sendo que tais juros não são tributados. Assim, a subvenção gerada pelo diferimento corresponde ao valor presente do tributo que teria incidido sobre os juros.
} 
$\mathrm{n}^{\text {o }}$ 2.158-35/01. Também é o sistema atualmente adotado pelos EUA ${ }^{354}$ no que tange às exportações realizadas por meio de empresas ligas em paraísos fiscais.

Nos casos (i) e (ii) mencionados acima, pode-se dizer que as regras benéficas de preços de transferência, ao viabilizarem a alocação dos lucros de exportação nas subsidiárias estrangeiras, efetivamente permitem um benefício fiscal, pois os lucros das subsidiárias não são tributados, ou ao menos têm a sua tributação diferida.

No caso (iii), vemos que, apesar de as regras benéficas de preços de transferência permitirem a alocação dos lucros de exportação na subsidiária estrangeira, tais lucros acabam sendo tributados no país da controladora no próprio exercício em que são auferidos pela subsidiária ${ }^{355}$.

Nesses termos, poder-se-ia sustentar que o mandamento da Nota de Rodapé $\mathrm{n}^{\circ}$ 59 somente se aplicaria para os países que adotem os sistemas descritos em (i) e (ii) supra, mas não para os países que se enquadrem no item (iii).

Todavia, esta linha de raciocínio merece duas ressalvas. Em primeiro lugar, não há nada na linguagem da Nota de Rodapé $\mathrm{n}^{\circ} 59$ que expressamente sustente este ponto de vista. Assim, não é certo que ele seria aceito pelo OSC da OMC.

Em segundo lugar, é possível verificar casos em que a alocação dos lucros de exportação numa subsidiária no exterior pode gerar economia tributária ainda que o país da controladora enquadre-se no item (iii) supra. Por exemplo, se a subsidiária no exterior tiver perdas acumuladas que possam ser compensados com os lucros de exportação nela alocados, tais lucros poderão escapar à tributação no país de residência da controladora ${ }^{356}$.

\footnotetext{
${ }^{354}$ As chamadas base company rules exigem que as regras da Subpart-F do IRC (que obrigam a tributação americana dos lucros das subsidiárias quando auferidos) apliquem-se a estes casos. AVI-YONAH, Reuven S., International Tax as International Law: An Analysis of the International Tax Regime, New York, Cambridge University Press, 2007, p. 137.

355 Sobre a relação entre as regras de preços de transferência e as regras CFC, veja SCHOUERI, Luís Eduardo, Aplicação concomitante da legislação de preços de transferência e da tributação do lucro em bases mundiais, in TORRES, Heleno Taveira (Org.), Direito Tributário Internacional Aplicado, $1^{\text {a }}$ ed., São Paulo, Quartier Latin, 2005, v. 3, p. 239-254.

356 Veja-se, por exemplo, o caso julgado no Acórdão n $\mathrm{n}^{\mathbf{0}}$ 105-17.084 do Conselho de Recursos Administrativos Fiscais, em que as regras de preços de transferência brasileiras permitiam alocação de parte do lucro da exportação da empresa brasileira em subsidiárias em paraísos físcais. Estes lucros foram compensados com perdas das subsidiárias e, portanto, não foram trazidos à tributação brasileira quando da aplicação do artigo 74 da MP 2.158. O CARF acabou decidindo que as exportações para as subsidiárias eram
} 
Uma segunda questão que pode ser trazida quanto à aplicação da Nota de Rodapé $n^{\circ} 59$ refere-se à simetria entre os ajustes de preços de transferência nas importações e exportações.

Um país que não adote regras de preços de transferência nas exportações, mas que também não o faça em relação às importações poderia arguir que não estaria outorgando qualquer subsídio, pois ainda que as empresas exportadoras residentes no país possam alocar lucros em subsidiárias no exterior, as empresas importadoras residentes nesse país também poderiam alocar lucros no exterior quando importassem produtos de partes ligadas.

Assim, o aparente subsídio à exportação seria compensado por igual subsídio à importação. Produtos importados e nacionais similares seriam tratados da mesma maneira, não havendo qualquer violação ao GATT.

Contudo, esta linha de raciocínio parece problemática por uma série de motivos.

Em primeiro lugar, as regras do ASMC não parecem permitir que um subsídio à exportação seja justificado por um subsídio similar aplicável às importações. Se a Nota de Rodapé $\mathrm{n}^{\text {o }} 59$ tem o condão de enquadrar a ausência de ajustes de preços de transferência arm's length nas exportações como um subsídio à exportação, o artigo 3 do ASMC deve ser aplicado e o subsídio será proibido.

Ademais, ainda que se possa defender que a ausência de ajustes de preços de transferência nas importações possa constituir um subsídio às importações, nada garante que tal subsídio será utilizado em igual montante ao subsídio às exportações (i.e., nada garante que a quantidade de exportações a partes ligadas no exterior corresponderá às importações de partes ligas do exterior).

Em terceiro lugar, o fato de produtos nacionais e importados similares serem tratados da mesma maneira pelas regras de preços de transferência (ou, no caso, ausência

simuladas e considerou que os lucros da exportação alocados nestas subsidiárias eram receitas omitidas pela controladora brasileira. 
de tais regras), é relevante para fins de aplicação do artigo III do GATT, mas não parece ter muita importância para fins de aplicação do $\mathrm{ASMC}^{357}$.

Assim, parece-nos que, nos termos da Nota de Rodapé $n^{\circ}$ 59, um Estado Membro da OMC que julgar que a aplicação relaxada de regras de preços de transferência nas exportações por outro Estado Membro resulta em expressiva economia em impostos direitos aplicáveis às transações de exportação, pode, em último caso, iniciar procedimento de consulta.

\section{III.7. Imunidade da CSLL nas exportações}

Questão interessante que poderia surgir em relação à aplicação do ASMC às regras de tributação da renda brasileiras refere-se à possível imunidade da CSLL sobre os lucros decorrentes de exportações.

A CSLL é contribuição social cobrada pela União, amparada no artigo 195, III, (c) da Constituição Federal, que incide sobre o lucro das pessoas jurídicas. O seu fato gerador e a sua base de cálculo praticamente correspondem ao fato gerador e à base de cálculo do Imposto de Renda das Pessoas Jurídicas. Sendo assim, a CSLL pode ser considerada um tributo sobre a renda e se enquadra no conceito de tributo direto constante da nota de rodapé 58 do ASMC.

O inciso I do $\S 2^{\circ}$ do artigo 149 da Constituição Federal determina que as contribuições sociais não incidirão sobre as receitas de exportação. Com base neste dispositivo, os contribuintes passaram a sustentar que a CSLL não deveria incidir sobre a parcela dos lucros das pessoas jurídicas decorrentes de exportações. O raciocínio baseavase no fato de, sendo o lucro composto por receitas e despesas, seria possível determinar a parcela do lucro correspondente às receitas de exportação (alocando-se as respectivas despesas a estas receitas). Ora, se a constituição outorga imunidade para as receitas de exportação, o lucro decorrente de tais receitas deve ser imune à tributação pela CSLL.

\footnotetext{
${ }^{357}$ Vale lembrar, ainda, que havendo conflito de interpretação entre o GATT e o ASMC, o Anexo I do Acordo da OMC determina que o ASMC é aplicável.
} 
A União, por seu turno, sustentava que a imunidade constitucional somente se aplica para as contribuições que incidem sobre a receita (PIS e COFINS), não abrangendo, portanto, contribuições que tenham outros fatos geradores, como, no caso, a CSLL.

O $\operatorname{STF}^{358}$ acabou decidindo a favor da União, com base no entendimento de que o artigo $149,2^{\circ}$, I, da Constituição Federal apenas outorga imunidade para as contribuições sociais cujo fato gerador é a receita, ou seja, o PIS e a COFINS.

Note-se que, em que pesem as ressalvas apontadas no tópico III.5 supra, a não tributação das receitas de exportação pelo PIS e pela COFINS (assim como a tributação das importações por estas contribuições, conforme determina $o$ artigo $1^{\circ}$ da Lei $n^{\circ}$ 10.865/04) é, em princípio, justificada nos termos da Nota de Rodapé 1 do ASMC e das regras de ajustes de fronteira do GATT em decorrência da possibilidade de o PIS e a COFINS serem considerados tributos indiretos nos termos da Nota de Rodapé 58 do ASMC.

Todavia, conforme apontamos, a CSLL é um tributo direto e não está sujeita às exceções da Nota de Rodapé $n^{\circ} 1$ do ASMC referente aos ajustes de fronteira.

Sendo assim, se o STF tivesse decidindo a questão da imunidade da CSLL nas exportações a favor dos contribuintes e declarado que esta contribuição não deveria incidir sobre a parcela dos lucros das pessoas jurídicas atribuível às exportações, provavelmente estaríamos diante de um subsídio proibido pelo artigo 3 do ASMC, veiculado por regra constitucional brasileira ${ }^{359}$.

\section{III.8. ASMC, tributação da renda e subvenções tributárias}

A exposição realizada neste capítulo permitiu-nos verificar que o ASMC aplica-se à tributação da renda, sendo que o teste para verificar se determinada medida de

\footnotetext{
${ }^{358}$ Destaquem-se as seguintes decisões do plenário do STF: RE 474.132/SC, Min. Relator Gilmar Mendes, julgado em 12.08.2010; RE 564.413/SC, Min. Relator Marco Aurélio, julgado em 12.08.2010.

${ }_{359}$ Foge ao nosso escopo lidar com a questão do eventual conflito entre a Constituição Federal e o GATT e o ASMC.
} 
tributação da renda veicula um subsídio remete à teoria das subvenções tributárias analisadas no Capítulo 1.

O caso FSC/ETI mostra claramente que é firme a adoção, pelo OSC, da lógica de que cada país tem um sistema tributário normativo "básico" que pode ser estabelecido como um parâmetro para a análise de uma medida específica em relação à qual há a suspeita de ser um subsídio tributário; um desvio deste parâmetro indicaria (na linha de raciocínio do Órgão de Apelação) um subsídio, uma vez que, tecnicamente, o tributo seria "devido, a não ser pela medida em questão", que é o teste que se usa para identificar tal desvio $^{360}$.

Ademais, o fato de a adoção, por um Estado-membro, de um determinado parâmetro de tributação o colocar em desvantagem no comércio internacional em relação a outros países, não possibilita que este Estado-membro adote subsídios para corrigir esta situação. Cada Estado Membro é livre para adotar o parâmetro de tributação que quiser, mas, após a adoção deste parâmetro, deverá conviver com a sua opção de política tributária.

360 BRAUNER, Yariv, Direito do comércio internacional e acordos tributários, Trad. Port. Gustavo Gonçalves Vettori, in Direito Tributário Atual nº 23, São Paulo, Dialética, 2009. 


\section{IV - GATS}

Neste capítulo, analisaremos a maneira pela qual o GATS aplicam-se à tributação da renda.

Para tanto, traçaremos um panorama das principais regras deste acordo e determinaremos em que hipóteses ele abrange medidas de tributação da renda adotada pelos Estados Membros da OMC.

Por fim, avaliaremos se o modelo das subvenções tributárias descrito no Capítulo I supra é aplicável para identificar as medidas de tributação da renda que se sujeitam à aplicação destes acordos.

\section{IV.1. Visão geral do acordo}

O GATS tem por objetivo estabelecer um quadro de referência multilateral de princípios e regras para o comércio de serviços, com vistas à sua expansão, sob condições de transparência a progressiva liberalização ${ }^{361}$.

O comércio de serviços funciona de acordo com lógica bastante diversa daquela aplicável ao comércio de bens. Enquanto este depende da passagem física de produtos pela fronteira dos Estados, serviços são fornecidos no mercado internacional por diversas formas de prestação, tais quais: movimento do produto do serviço através das fronteiras; movimento do consumidor através da fronteira; presença comercial do prestador; e movimento temporário da pessoa física prestadora do serviço. $\mathrm{O}$ setor de serviços inclui, assim, não apenas o comércio de serviços registrado no balanço de pagamento dos países, mas também a venda local das subsidiárias de empresas estrangeiras $^{362}$.

361 THORSTENSEN, Vera, OMC - Organização Mundial do Comércio: as regras do comercio internacional e a nova rodada de negociações multilaterais, $2^{\mathrm{a}}$ ed., São Paulo, Aduaneiras, 2001, p. 197. ${ }^{362}$ Idem, ibidem, p. 195. 
Da mesma maneira, as formas utilizadas pelos governos para proteger seus setores nacionais de serviços são diversas daquelas empregadas para o comércio de bens. Enquanto bens são primordialmente protegidos por tarifas ${ }^{363}$ e medidas de fronteiras, serviços geralmente são protegidos por regras que limitam investimentos e participação de prestadores de serviços estrangeiros na economia doméstica. Estas regras podem impedir a participação em determinados setores, discriminar prestadores nacionais e estrangeiros, ou até mesmo dar tratamento distinto entre prestadores de diversos países ${ }^{364}$.

Nesses termos, diferentemente do GATT, do Acordo TRIMS e do ASMC, que lidam somente com produtos e a sua circulação, o GATS aplica-se tanto aos serviços quanto aos seus prestadores.

Suas regras aplicam-se às "medidas adotadas pelos Membros" que afetem o comércio de serviços (artigo I:1). A expressão "medidas adotadas pelos Membros" referese às medidas tomadas por governos centrais, regionais e locais, autoridades e órgãos não governamentais, no exercício de seus poderes, quando delgados pelos governos ou autoridades. Tais medidas incluem leis, regulamentos, regras, procedimentos, decisões e ações administrativas (artigo I:3).

O artigo I do GATS define "serviços" como qualquer serviço em qualquer setor exceto aqueles prestados no exercício da autoridade governamental (i.e., serviços que não sejam prestados em bases comerciais, nem em competição com um ou mais prestadores de serviços) e segrega o comércio destes serviços em quatro modos diferentes de prestação, quais sejam:

(i) Do território de um Membro ao território de qualquer outro Membro (cross border suply); categoria esta que inclui, por exemplo, serviços transmitidos por redes de telecomunicações, projetos de engenharia, serviços de transporte etc. ${ }^{365}$;

\footnotetext{
${ }^{363}$ As barreiras não tarifárias discriminatórias têm o efeito de replicar, bem ou mal, o efeito de tarifas.

364 THORSTENSEN, Vera, OMC - Organização Mundial do Comércio: as regras do comercio internacional e a nova rodada de negociações multilaterais, 2a ed., São Paulo, Aduaneiras, 2001, p. 195.

${ }^{365}$ Idem, ibidem, p. 198.
} 
(ii) Dentro do território de um Membro aos consumidores de serviços de qualquer outro Membro (consumption abroad), categoria esta que inclui, por exemplo, turismo, educação, serviços médicos etc. ${ }^{366}$;

(iii) Pelo prestador de serviços de um Membro, por intermédio da presença comercial no território de qualquer outro Membro (comercial presence), categoria esta que inclui, por exemplo, subsidiárias ou filiais de empresas tais quais bancos, seguradoras etc. ${ }^{367}$;

(iv) Pelo prestador de serviços de um Membro, por intermédio da presença de pessoas naturais de um Membro no território de qualquer outro Membro (presence of natural persons), categoria esta que inclui, por exemplo, consultores, jogadores, músicos etc. ${ }^{368}$.

O GATS foi negociado em quatro partes distintas. A primeira estabelece um quadro de regras, obrigações e princípios gerais que se aplicam a medidas que afetam o comércio de serviços. A segunda remete aos anexos que determinam princípios e regras aplicáveis a setores específicos. A terceira estabelece, para cada membro do acordo, uma série de compromissos de liberação para cada setor, de acesso a mercado e de tratamento nacional. Tais compromissos foram incluídos nas listas nacionais de cada membro do acordo. A quarta parte estabelece listas em setores nos quais os membros não aplicam o princípio da Nação Mais Favorecida (listas negativas) ${ }^{369}$.

Desta maneira, a negociação de serviços assumiu uma forma distinta da negociação do comércio de produtos. Neste último, foram negociadas regras gerais aplicáveis a todos os segmentos. No setor de serviços a liberalização assumiu uma forma progressiva, materializando-se através da consolidação da abertura de cada segmento em listas de compromissos ${ }^{370}$.

\footnotetext{
366 THORSTENSEN, Vera, OMC - Organização Mundial do Comércio: as regras do comercio internacional e a nova rodada de negociações multilaterais, $2^{\mathrm{a}}$ ed., São Paulo, Aduaneiras, 2001, p. 198.

367 Idem, ibidem, p. 198.

368 Idem, ibidem, p. 198.

369 Idem, ibidem, p. 196.

${ }^{370}$ Idem, ibidem, p. 196.
} 


\section{IV.2. Aplicação à tributação da renda}

No que tange à tributação da renda, é relevante analisar as regras de Tratamento da Nação Mais Favorecida (artigo II), Tratamento Nacional (artigo XVII) e Subsídios (artigo XV) do GATS.

Note-se que as regras de Tratamento da Nação Mais Favorecida e de Subsídios, por se encontrarem na Parte II do acordo (que regulamenta as "Obrigações e Disciplinas Gerais"), aplicam-se a quaisquer medidas, a não ser que o Membro em questão tenha firmado anexo contendo exclusões específicas ${ }^{371}$.

A regra de Tratamento Nacional, por seu turno, aplica-se apenas aos casos em que o Membro assumiu um compromisso específico em relação a esta obrigação, sendo que a extensão dos compromissos de cada Membro em relação a determinado setor de serviços deve ser analisada de acordo com o anexo firmado pelo Membro em questão (listas positivas) $^{372}$.

Por fim, as Exceções Gerais constantes do artigo XIV, aplicam-se a todas as disposições do acordo e serão de fundamental relevância na aplicação do GATS à tributação da renda.

\section{IV.2.1. Escopo de aplicação}

Conforme mencionado, diferentemente do GATT, cujas regras de Tratamento da Nação Mais Favorecida e Tratamento Nacional aplicam-se apenas a produtos, as regras de Tratamento Nacional e Tratamento da Nação Mais Favorecida do GATS aplicam-se a serviços e aos prestadores de serviços dos membros.

A inclusão dos prestadores de serviços é de relevância fundamental para a aplicação destas regras aos tributos sobre a renda.

371 THIEL, Servaas van, General report, in LANG, Michael, HERDIN, Judith, HOFBAUER, Ines (org.), WTO and direct taxation, Kluwer Law, 2005, p.35.

${ }^{372}$ Idem, ibidem, p. 35. 
Conforme verificamos ao longo de todo o Capítulo II supra, a maior dificuldade na aplicação do GATT à tributação da renda é que as regras dos artigos I e III aplicavam-se apenas a medidas que discriminassem produtos. Como a tributação da renda incide sobre a renda auferida por pessoas, apenas em casos excepcionais medidas de tributação da renda discriminariam produtos.

No caso do GATS, devido à inclusão dos prestadores de serviços, não há a referida dificuldade, pois os tributos sobre a renda incidem sobre a renda de tais prestadores. Desta maneira, se não fossem as exceções do artigo XIV (que analisaremos adiante), o GATS abrangeria medidas fundamentais relacionadas à tributação da renda.

Isso não deve significar, todavia, que o mero fato de uma pessoa qualificar-se como prestador de serviços dará pronto amparo contra qualquer medida discriminatória que a ela seja aplicada.

Vejamos o seguinte exemplo: o Estado Membro A trata as remessas de dividendos de portfólio para residentes do Estado Membro B de forma mais favorável do que as remessas destes mesmos dividendos para residentes do Estado Membro C. O tratamento discriminatório em investimentos de portfólio não é coberto pelo GATS ou por qualquer outro acordo no âmbito da OMC. Sendo assim, em princípio, o Estado C não teria remédios contra a referida discriminação.

No entanto caberia indagar se algo mudaria se os residentes dos Estados B e C (que recebem os dividendos) fossem prestadores de serviços. Poderia o Estado C buscar o amparo da regra da Nação Mais Favorecida do GATS para requerer que o Estado A tratasse as remessas de dividendos de portfólio aos seus prestadores de serviços da mesma maneira que ele trata as remessas para os prestadores de serviços do Estado B?

Em nossa visão, a resposta deve ser negativa. A análise deve partir do artigo I:1 do GATS, que determina que "este Acordo se aplica às medidas adotadas pelos Membros que afetem o comércio de serviços".

Investimentos de portfólio, por seu turno, não são diretamente relacionados com a prestação de serviços. Ainda que a empresa investidora e a empresa na qual se investiu sejam prestadoras de serviços, o objetivo do investimento de portfólio é, do lado 
do receptor dos recursos, o angariamento de recursos no mercado de capitais e, do lado do investidor, a produção de renda passiva. O investidor não participa do negócio da investida. Por isso, o investimento em questão não se relaciona diretamente com uma prestação de serviços transfronteiriça.

É claro que a restrição imposta pelo Estado A desencorajará os residentes de B a investir em A. Isso prejudicará o financiamento das empresas de A pelo capital advindo do Estado B. Considerando que o capital é um fator de produção, se as empresas em questão forem prestadoras de serviços, o comércio de serviços será indiretamente afetado. No entanto, essa relação indireta não é, em nossa visão, suficiente para o enquadramento da medida restritiva no artigo I do GATS.

Em resumo, no exemplo apresentado, a medida discriminatória, apesar de afetar um prestador de serviços, não afeta o comércio de serviços nos moldes exigidos pelo artigo I:1 e, deste modo, não está sujeita à aplicação do GATS. Entender de outra forma seria estender o escopo do GATS a áreas que ele não se presta a cobrir.

Parece ser este o entendimento adotado pelo Órgão de Apelação no caso Canada - Certain Measures Affecting the Automotive Industry ${ }^{373}$, ao elucidar que " $a$ análise de inconsistência de uma medida com o artigo II:1 deve ser feita em vários passos. Primeiro, como vimos, deve-se determinar se são cumpridos os requisitos do artigo I:1, ou seja se a medida é coberta pelo GATS. Esta determinação requer que haja o 'comércio de serviços em uma de suas quatro formas de fornecimento e também haja uma medida que 'afete' este comércio de serviços.”

Contudo, a questão torna-se mais complicada quando nos deparamos com medidas que não se aplicam exclusivamente às prestações de serviços, mas as afetam. Por exemplo, o Estado A impõe limitações à remessa de dividendos de subsidiárias situadas em A para controladoras no Estado B, mas não impõe tais limitações nas remessas de dividendos a controladoras no Estado C. Estas limitações não se aplicam apenas às prestadoras de serviços, mas a subsidiárias e controladoras em qualquer ramo de atividade.

Supondo que os países A e B são signatários do GATS, a questão é: controladoras prestadoras de serviços do Estado B que tenham subsidiárias no Estado A

\footnotetext{
${ }^{373}$ WT/DS139/AB/R e WT/DS142/AB/R, parágrafo 170, p. 55.
} 
para prestar serviços neste país, no modo commercial presence, poderiam ser limitadas pelo Estado A no recebimento de seus dividendos, considerando que controladoras prestadoras de serviços similares do Estado C não o são? O Estado B, com base na regra da Nação Mais Favorecida, poderia exigir que o Estado A não limitasse o pagamento de dividendos às controladoras em $\mathrm{B}$ quando tais controladoras forem prestadoras de serviços?

Note-se, novamente, que a limitação imposta por A não é voltada exclusivamente a prestadores de serviços. Ela se aplica a remessas de quaisquer subsidiárias de A a controladoras em $\mathrm{B}$, independentemente dos seus ramos de atividade.

Todavia, neste caso, os dividendos decorrem do investimento direto feito por uma empresa do Estado B numa subsidiária no Estado A. O objetivo da controladora com tal investimento não é auferir renda passiva, mas realizar as suas atividades no mercado de A por meio da subsidiária. A medida do Estado A que limita o pagamento dos dividendos desincentiva a atuação de empresas do Estado B (dentre as quais prestadoras de serviço) no mercado de A por meio da instalação de subsidiárias, restringindo, portanto, tal atuação.

Neste caso, não há como negar que a regra do Estado A, quando aplicada a prestadores de serviços, afeta o comércio de serviços. Ainda que a medida de A não seja de aplicação exclusiva a prestadores de serviços, cremos que ela se enquadra no artigo I:1 do GATT e a sua aplicação aos prestadores de serviços deve se submeter às regras deste $\operatorname{acordo}^{374}$.

\section{IV.2.2. Exceções gerais}

O segundo ponto relevante para determinar a aplicação das regras do GATS à tributação da renda refere-se às Exceções Gerais previstas no artigo XIV. Os dispositivos relevantes deste artigo são as alíneas (a), (c)(i), (d) e (e).

\footnotetext{
374 THIEL, Servaas van, General report, in LANG, Michael, HERDIN, Judith, HOFBAUER, Ines (org.),
} WTO and direct taxation, Kluwer Law, 2005, p. 36. 
Deles se extrai que, com a ressalva de que as medidas não sejam aplicadas de forma que constituam um meio de discriminação arbitrário ou injustificável entre países em que prevaleçam condições similares, ou que as medidas constituam restrições encobertas ao comércio de serviços:

(i) O Tratamento da Nação Mais Favorecida não veda medidas que imponham diferença de tratamento que resulte de um acordo de bitributação ou de disposições destinadas a evitar a dupla tributação contidas em qualquer outro acordo ou convênio internacional pelo qual o Membro esteja vinculado (artigo XIV (e)).

(ii) O Tratamento Nacional não veda medidas que imponham diferença de tratamento com o objetivo de assegurar a imposição ou coleta equitativa ou efetiva de impostos diretos em relação a serviços ou prestadores de serviços de outros Membros (artigo XIV(d)).

(iii) Nenhuma das regras do GATS afetará medidas necessárias para manter a ordem pública e para assegurar a observância das leis e regulamentos (que não sejam incompatíveis com as disposições do GATS) voltados à prevenção de práticas dolosas ou fraudulentas (artigo XIV alíneas (a) e (c)(1)).

Os detalhes das exceções (i) e (ii) supra, específicas respectivamente ao Tratamento da Nação Mais Favorecida e ao Tratamento Nacional, serão abordados com mais detalhes nos tópicos IV.2.3.2 e IV.2.4 infra.

No tópico IV.2.2.1 a seguir examinaremos as exceções de ordem pública e para prevenção de práticas dolosas ou fraudulentas mencionadas no item (i) supra.

No tópico IV.2.2.2 infra, lidaremos com a ressalva feita pelo caput do artigo XIV à aplicação de todas as exceções ora mencionadas. 


\section{IV.2.2.1. Exceções de ordem pública e para evitar práticas dolosas ou} fraudulentas

As exceções das líneas (a) e (c)(1) do artigo XIV lidam com medidas necessárias para manter a ordem pública e para evitar práticas dolosas ou fraudulentas e são aplicáveis a todas as regras do GATS. Cabe indagar se medidas de tributação da renda podem se enquadrar nestas exceções.

$\mathrm{Na}$ ausência de jurisprudência da OMC sobre o significado das exceções do artigo XIV do GATS, devemos buscar outros meios para interpretá-las.

O TCE possui exceção de ordem pública à aplicação das liberdades fundamentais, sendo que tal exceção já foi analisada pelo TJCE à luz de medidas de tributação da renda.

Acreditamos que os parâmetros utilizados pelo TJCE para elucidar a exceção de ordem pública poderiam ser tomados como esclarecedores do "sentido comum" - nos termos do artigo 31:1 da CVDT - de tal exceção e, portanto, aplicáveis para a interpretação do artigo XIV do GATS.

Ainda que o TCE e a jurisprudência do TJCE não façam parte do "contexto" do GATS, por não se enquadrarem no artigo 31:2 da CVDT, é possível defender que o “objetivo e a finalidade" das exceções de ordem pública do TCE se coadunam com o objetivo e a finalidade da exceção do artigo XIV(a) do GATS, razão pela qual acreditamos que o recurso à jurisprudência do TJCE é válido para elucidar o "sentido comum" da exceção do GATS.

Nesses termos, cremos que seja possível traçar um paralelo entre a exceção por ordem pública do GATS e as exceções por ordem pública constantes dos artigos 30, 39:3, 46 e 58(1)(b) do TCE $^{375}$ e, assim, determinar a possibilidade da aplicação do artigo XIV(a) do GATS a medidas de tributação da renda.

\footnotetext{
${ }^{375}$ Apesar destes artigos não se aplicarem especificamente à liberdade de serviços do artigo 50 (que não é excepcionada), a estrutura do TCE é construída de tal modo que a liberdade de serviços complementa as liberdades de movimentação de bens, estabelecimento e capitais, aplicando-se quando a prestação de serviços não envolver estas outras liberdades (apesar de este nem sempre ter sido o entendimento do TJCE). Assim, na medida que a exceção de ordem pública aplica-se a estas outras liberdades, ela também é relevante para a
} 
Ao analisar a exceção da ordem pública em relação a medidas tributárias discriminatórias ou restritivas das liberdades fundamentais, o TJCE indaga se tais medidas servem a um interesse público que deve ser sopesado em relação a tais liberdades fundamentais $^{376}$.

O tribunal tende a aceitar as seguintes justificativas de interesse público ${ }^{377}$ : (i) coerência do sistema de tributação da renda; (ii) medidas para evitar a evasão e a elisão ${ }^{378}$; e (iii) medidas para viabilizar a fiscalização e aplicação das normas tributárias. Outros tipos de justificativas, tais quais a perda de receita de arrecadação por um EstadoMembro ${ }^{379}$, prevenção de vício de jogo, divórcio e suicídios, dificuldades administrativas em obter informações do exterior e argumentos de minimis ${ }^{380}$, não são aceitas pelo TJCE para amparar uma medida discriminatória ou restritiva das liberdades fundamentais.

Mesmo em relação às justificativas de ordem pública aceitas, o TJCE tem adotado postura bastante restritiva. A evolução da jurisprudência mostra que tais justificativas são paulatinamente limitadas pelo TJCE. A coerência do sistema de tributação da renda, por exemplo, apesar de aceita no caso Bachmann ${ }^{381}$, foi praticamente reduzida à inaplicabilidade nos casos Manninen $^{382}$ e Meilicke ${ }^{383}$. Ademais, a interpretação estreita dos conceitos de evasão e elisão fiscal adotada pelo TJCE no caso Cadbury Schweppes $^{384}$ é outro indício da abordagem restritiva deste tribunal em relação às justificativas para medidas discriminatórias e restritivas.

Ainda, a presença de uma justificativa não é, em si, suficiente para que o TJCE aceite uma medida discriminatória. Havendo a justificativa de ordem pública, o tribunal aplica mais dois testes, quais $\operatorname{sejam}^{385}$ : (i) se a medida restritiva em questão é apropriada para a proteção do interesse público envolvido (ou seja, ela é efetiva? faz sentido?); e (ii)

liberdade de serviços. TERRA, Ben J. M., WATTEL, Peter, J., European tax law, $5^{\mathrm{a}}$ ed., Alphen aan den Rijn, Kluwer, 2008, p. 50.53.

${ }^{376}$ Idem, ibidem, p. 50.

${ }^{377}$ GAMMIE, Malcolm, The role of the European Court of Justice in the development of direct taxation in the European Union, in BIFD, v. 57, 2003, pp. 91 e ss. TERRA, Ben J. M., WATTEL, Peter, J., European tax law, $5^{\text {a }}$ ed., Alphen aan den Rijn, Kluwer, 2008, p. 50.

${ }^{378}$ Significando, neste contexto, planejamento abusivo.

${ }^{379}$ GAMMIE, Malcolm, op. cit.,92.

380 TERRA, Ben J. M., WATTEL, Peter, J., op. cit., p. 51.

${ }^{381}$ C-204/90.

${ }^{382} \mathrm{C}-319 / 02$.

${ }^{383}$ C- $-292 / 04$.

${ }^{384}$ C-196-04.

385 TERRA, Ben J. M., WATTEL, Peter, J., op. cit., p. 51. 
se a medida é proporcional nos seus efeitos restritivos em relação ao objetivo legítimo visado (ou seja, há outras medidas igualmente efetivas para atingir o objetivo visado que seriam menos restritivas às liberdades fundamentais?).

Estes testes, nada mais são do que o teste de proporcionalidade em sentido amplo. Quando há dois princípios em jogo (e.g., liberdade fundamental e proteção da ordem pública), que têm de ser sopesados em um caso concreto, tal teste presta-se a verificar se o sopesamento foi feito adequadamente em relação a uma medida concreta. $\mathrm{O}$ teste consiste de três etapas, quais sejam ${ }^{386}$ :

(i) Adequação: indaga-se se a medida é adequada para atingir os objetivos visados (se não é adequada, não pode ser justificada pelo objetivo apontado);

(ii) Necessidade: indaga-se se a medida é necessária em relação a tais objetivos (ou seja, o que vai além do necessário não deve ser aceito);

(iii) Proporcionalidade em sentido estrito (ou razoabilidade): indaga-se se a medida, mesmo sendo adequada e necessária, é a que menos restringe direitos (ou outros princípios) em jogo.

Assim, a medida restritiva das liberdades fundamentais justificada na proteção da ordem pública somente será aceita pelo TJCE se passar neste teste de proporcionalidade.

Como já adiantamos, acreditamos que toda esta linha de raciocínio pode ser adotada na aplicação do artigo XIV(a) do GATS.

Nesse sentido, seria possível defender que medidas de tributação da renda que se prestem a (i) garantir a coerência do sistema; (ii) evitar a evasão e a elisão; e (iii) viabilizar a fiscalização e aplicação das normas tributárias, poderiam ser excepcionadas da aplicação do GATS com fundamento da exceção de ordem pública constante do artigo XIV(a), desde que utilizadas de forma proporcional pelo Estado signatário.

\footnotetext{
${ }^{386}$ ÁVILA, Humberto, Sistema constitucional tributário, São Paulo, Saraiva, 2004, pp. 399-407.
} 
A exceção constante da alínea (c)(1) do artigo XIV reforçaria os itens (ii) e (iii) acima, pois medidas para viabilizar a fiscalização das normas tributárias e evitar a evasão e a elisão podem, em nossa visão, ser consideradas leis e regulamentos voltados à prevenção de práticas dolosas ou fraudulentas.

Em relação à exceção sobre a ordem pública, vale notar ainda que a Nota de Rodapé $n^{\circ} 5$ do artigo XIV do GATS esclarece que ela somente poderá ser invocada se houver ameaça verdadeira e suficientemente grave para um dos interesses fundamentais da sociedade. Esta restrição feita pela Nota de Rodapé $n^{\circ} 5$, em nosso ver, se coaduna com a interpretação restritiva feita pelo TJCE.

Por fim, vale notar que o teste de proporcionalidade utilizado pelo TJCE parece se coadunar com a ressalva prevista no caput do artigo XIV do GATS, que se aplica a todas as exceções previstas nas alíneas do artigo XIV do GATS. Analisaremos, a seguir, o teor desta ressalva.

\section{IV.2.2.2. Ressalva às exceções}

O caput do artigo XIV dispõe que:

"Sob reserva de que as medidas abaixo enumeradas não sejam aplicadas de forma que constituam um meio de discriminação arbitrário ${ }^{387}$ ou injustificável entre países em que prevaleçam condições similares ou uma restrição encoberta ao comércio de serviços, nenhuma disposição do presente Acordo será interpretada no sentido de impedir que um Membro adote ou aplique medidas:(...)”

\footnotetext{
${ }^{387}$ A versão em português e a versão oficial em espanhol do artigo XIV GATS fazem a concordância de "arbitrário" com o termo "meio" e não com discriminação. Na versão oficial em francês não é possível distinguir se "arbitraire" ou "injustifiable" referem-se a "moyen" ou "discrimination", devido à neutralidade de gênero dos adjetivos. A versão oficial em inglês, todavia, refere-se a "means of arbitrary or unjustifiable discrimination between countries". Fica claro, na versão em inglês que "arbitrary" e "unjustifiable" referem-se a "discrimination" e não a "means". Diferentemente do GATS, a redação em português e em espanhol do caput do artigo XX do GATT (que, conforme veremos, tem finalidade similar à do caput do artigo XIV) relacionam o adjetivo "arbitrário" a "discriminação" e não a "meios". Acreditamos, mesmo em relação ao artigo XIV do GATS, que o entendimento mais adequado é que "injustificável" e "arbitrário" refiram-se a discriminação.
} 
Vemos que este dispositivo faz duas ressalvas às exceções do artigo XIV, que não devem aplicadas de modo a constituírem:

(i) um meio de discriminação arbitrário ou injustificável entre países em que prevaleçam condições similares; ou

(ii) uma restrição encoberta ao comércio de serviços.

Como não há jurisprudência da OMC analisando o caput do artigo XIV do GATS $^{388}$, devemos recorrer a outros meios para interpretá-lo.

O caput artigo XX do GATT, que trata das exceções a este acordo, possui caput com redação similar à redação do caput do artigo XIV do GATS. Vejamos:

"Desde que essas medidas não sejam aplicadas de forma a constituir quer um meio de discriminação arbitrária, ou injustificada, entre os países onde existem as mesmas condições, quer uma restrição disfarçada ao comércio internacional, disposição alguma do presente capítulo será interpretada como impedindo a adoção ou aplicação, por qualquer Parte Contratante, das medidas:(...)"

Devido à similaridade de redação entre o caput dos artigos XIV do GATS e XX do GATT e considerando que ambos desempenham função similar em cada um destes tratados, cremos que a análise da jurisprudência da OMC acerca da aplicação do artigo XX do GATT pode ser útil para informar a interpretação do artigo XIV do GATS ${ }^{389}$, pois pode elucidar o "sentido comum" (artigo 31:1 da CVDT) da ressalva feita pelo caput deste último $^{390}$.

Os artigos 30 e 58 do TCE, por sua vez, preveem respectivamente exceções às proibições de restrição quantitativa (artigos 28 de 29) e à liberdade de movimento de

\footnotetext{
388 THIEL, Servaas van, General report, in LANG, Michael, HERDIN, Judith, HOFBAUER, Ines (org.), WTO and direct taxation, Kluwer Law, 2005, p. 39.

${ }^{389}$ GALÁN, Paula, The meaning of "arbitrary and unjustifiable discrimination" and "disguised restriction", in HERDIN-WINTER, Judith, HOFBAUER, Ines (org.), The relevance of WTO law for tax matters, Wien, Linde, 2006, p. 184.

${ }^{390}$ Ademais, o GATT poderia se enquadrar no artigo 31:3(c) da CVDT.
} 
capitais e pagamentos (artigo 56). Dentre as exceções trazidas pelo artigo 30, encontra-se a ordem pública. $\mathrm{O}$ artigo 58 também traz a exceção de ordem pública.

Ambos os artigos preveem ressalvas às exceções por eles veiculadas. Tais ressalvas visam a impedir que as exceções não constituam um meio de "discriminação arbitrária nem qualquer restrição dissimulada" ao comércio entre os Estados Membros, ou à livre circulação de capitais e pagamentos.

Ou seja, os artigos 30 e 58 possuem exceções e ressalvas similares àquelas previstas no artigo XIV do GATS. Dessa forma, a jurisprudência do TJCE poderia ser utilizada para informar a interpretação do artigo XIV do GATS, elucidando o "sentido comum" das ressalvas feitas pelo seu caput.

Paula Galán ${ }^{391}$ realiza análise dentro destes parâmetros, sendo que exporemos a seguir os principais pontos de sua pesquisa.

Anteriormente à constituição da OMC, cumpre apontar duas decisões relevantes que analisaram a aplicação do artigo XX do GATT.

A primeira delas é o Relatório do Painel em United States - Prohibition of Imports of Tuna and Tuna Products from Canada ${ }^{392}$. Neste caso, o Painel entendeu que as medidas, impostas pelos Estados Unidos, restritivas à importação de atum e derivados do Canadá, não eram arbitrárias ou injustificadas pois os Estados Unidos tinham adotado medidas similares em relação às importações de outros países por razões similares.

No caso United States - Imports of Certain Automotive Spring Assemblies ${ }^{393}$, o Painel entendeu que, como a medida se enquadrava em uma das alíneas do artigo XX (alínea (d), no caso), não era necessária a análise à luz do caput, pois a ressalva não se aplicaria. Acrescentou, ainda, que, se a medida fosse analisada à luz do caput, não seria uma discriminação arbitrária ou injustificável porque era direcionada contra a importação de produtos automotivos em violação a patentes americanas advindos de qualquer país, e não apenas do Canadá.

\footnotetext{
${ }^{391}$ GALÁN, Paula, The meaning of "arbitrary and unjustifiable discrimination" and "disguised restriction", in in HERDIN-WINTER, Judith, HOFBAUER, Ines (org.), The relevance of WTO law for tax matters, Wien, Linde, 2006, pp 187-208.

${ }^{392}$ L/5198-29S/91.

${ }^{393}$ L/5333-30S/107.
} 
Em 1996, o Relatório do Órgão de Apelação no caso United States - Standards for Reformulated and Conventional Gasoline ${ }^{394}$ trouxe algumas inovações na aplicação do artigo XX. Em primeiro lugar, ele muda o entendimento do Painel em United States Imports of Certain Automotive Spring Assemblies quanto à não aplicação do caput às medidas que se enquadram nas alíneas do artigo XX. Na visão do Órgão de Apelação, o fato de uma medida justificar-se por alguma das alíneas do artigo XX não significa que estará isenta da análise sob o caput deste artigo. Assim o exame da medida deve percorrer as seguintes etapas ${ }^{395}$ :

(i) Em primeiro lugar, deve-se determinar se a medida é discriminatória ou protecionista à luz das regras do $\mathrm{GATT}^{396}$;

(ii) Após, deve-se verificar se há alguma justificativa para a medida nas exceções constantes das alíneas do artigo XX;

(iii) Por fim, deve-se determinar se a medida, apesar de justificada, não é, nos termos do caput do artigo XX, um meio de discriminação arbitrária, ou injustificada, entre os países onde existem as mesmas condições, ou uma restrição disfarçada ao comércio internacional.

No caso, Órgão de Apelação entendeu que as medidas, apesar de justificadas, discriminavam entre produtos nacionais e importados similares, pois os critérios impostos pelos Estados Unidos para a gasolina importada eram mais rigorosos do que aqueles aplicáveis à gasolina produzida no país. Esta discriminação era injustificada e, por este motivo, não deveria prevalecer.

Ainda, o Órgão de Apelação apontou que as palavras "discriminação arbitrária", "discriminação injustificada" e "restrição disfarçada" devem ser lidas lado a lado, de modo a outorgar significado uma a outra. A interpretação de todas elas deve ser feita, conforme dispõe o artigo 31 da CVDT, à luz do objetivo do caput, que, na visão do Órgão de Apelação, é evitar o abuso das exceções constantes das alíneas do artigo XX.

\footnotetext{
${ }^{394}$ WT/DS27/AB/R.

${ }^{395}$ Este mesmo método de análise foi usado em United States - Import Prohibition of Certain Shrimp and Shrimp Products, WT/DS58/AB/R.

396 O Relatório do Órgão de Apelação em European Communities - Measures Affecting Asbestos and Asbestos Containing Products, WT/DS135/AB/R, ao analisar o artigo XX, aponta que, se a medida em questão não é discriminatória e não gera qualquer efeito protecionista, deve ser aceita.
} 
No caso United States - Import Prohibition of Certain Shrimp and Shrimp Products $^{397}$ o Órgão de Apelação lidou com medida dos Estados Unidos que condicionava o acesso de camarões ao seu mercado à utilização de métodos de pesca que reduziam o risco de captura acidental de tartarugas. O problema é que os EUA baniram a importação em relação a alguns membros da OMC enquanto negociaram soluções amigáveis com outros membros para tentar atingir a política visada. O Órgão de Apelação considerou que o banimento era um meio de discriminação injustificada, tendo em vista a possibilidade de soluções amigáveis. Na visão do Órgão de Apelação, os EUA não tiveram a mesma diligência em negociar soluções cooperativas com todos os Membros.

Por um lado, o raciocínio do Órgão de Apelação neste caso guarda semelhança com o dos painéis nos casos United States - Prohibition of Imports of Tuna and Tuna Products from Canada e United States - Imports of Certain Automotive Spring Assemblies mencionados acima. Em todos os casos, não foram aceitas medidas que, apesar de justificadas, tratavam de maneira diversa diferentes membros em igual situação.

Por outro lado, é possível ver neste caso indícios da aplicação de um teste de proporcionalidade na análise da medida. Com efeito, banir a importação e negociar uma solução amigável são dois meios efetivos para se atingir o objetivo visado pelos EUA. Contudo, soluções negociadas são menos restritivas do GATT do que o banimento. Portanto, a necessidade e a razoabilidade pediriam que a solução negociada fosse aplicada.

Apesar de não ser possível saber qual seria a conclusão do Órgão de Apelação neste caso se os EUA simplesmente tivessem banido a importação de camarões de todos os países que não se coadunassem com as medidas de pesca, o Relatório dá indícios de que não seriam aceitas medidas que fossem abusivas em relação ao objetivo visado. De fato, o Relatório mostra que o caput do artigo XX requer boa-fé na aplicação das medidas e relaciona a expressão "discriminação arbitrária ou injustificável” com o abuso do direito.

Na visão do Órgão de Apelação, o abuso do direito seria proibido, pois seria contrário à boa-fé, que é princípio geral do direito internacional. O exercício razoável e em boa-fé de um direito seria aquele que é apropriado e necessário em relação ao propósito de tal direito.

${ }^{397}$ WT/DS58/AB/R. 
Saliente-se que o adjetivo "necessário" é empregado nas alíneas do artigo XX do GATS para qualificar algumas das medidas excepcionais constantes destas alíneas. O Painel do GATT em United States - Section 337 of the Tariff Act of $1930^{398}$ analisa este adjetivo e conclui que a exigência de que uma medida seja "necessária" para atingir um fim implica que um membro deve escolher, entre as medidas razoavelmente disponíveis, aquela que seja consistente com as regras do GATT e, se nenhuma medida disponível for consistente com tais regras, deve escolher a medida que seja menos inconsistente com as regras do GATT.

Ora, os referidos testes não diferem do teste de proporcionalidade em sentido amplo referido no tópico IV.2.2.1 supra. Conforme mencionamos, é este teste que o TJCE aplica para verificar se medidas discriminatórias ou restritivas das liberdades fundamentais, ainda que justificadas, devem ser aceitas.

Assim, utilizando a interpretação jurisprudencial do caput artigo XX do GATT, bem como a linha de raciocínio do TJCE, para informar a interpretação do caput do artigo XIV do GATS, podemos concluir que, ao analisarmos uma medida aplicada por um Membro a serviços ou seus prestadores de outro Membro, devemos adotar o seguinte método de análise:

\section{(i) Verificar se:}

a. A medida contraria as regras do GATS;

b. A medida pode ser justificada em alguma das alíneas do artigo $\mathrm{XIV}^{399}$; e

c. Ainda que amparada nas alíneas do artigo XIV, a medida se coaduna com o caput deste artigo. A medida se coadunará com o caput se:

\footnotetext{
${ }^{398} \mathrm{~L} / 6439-36 \mathrm{~S} / 345$.

399 Obviamente, ainda que não tenha amparo nas alíneas do artigo XIV, a medida pode ser excepcionada da aplicação das regras do GATS por algum outro motivo. Por exemplo, ela pode constar da lista do anexo do Estado Membro referente a medidas excepcionadas do Tratamento da Nação Mais Favorecida, ou simplesmente não constar da lista positiva de aplicação do tratamento nacional ao Estado Membro em questão.
} 
i. Não diferenciar países em iguais condições, além do necessário para atingir o fim visado;

ii. Não tiver efeito protecionista, ou seja, não diferenciar serviços e prestadores de serviços nacionais e estrangeiros além do necessário para atingir o fim visado;

iii. For proporcional, ou seja: adequada, necessária e razoável em relação ao fim visado.

Feitas estas considerações, podemos partir para a análise das regras específicas do GATS que afetam a tributação da renda.

\section{IV.2.3. Nação mais favorecida}

\section{IV.2.3.1. Visão geral}

O artigo II do GATS disciplina o Tratamento da Nação Mais favorecida para fins deste acordo, dispondo que:

"1. Com respeito a qualquer medida coberta por este Acordo, cada Membro deve conceder imediatamente e incondicionalmente aos serviços e prestadores de serviços de qualquer outro Membro, tratamento não menos favorável do aquele concedido a serviços e prestadores de serviços similares de qualquer outro país.

2. Um Membro poderá manter uma medida incompatível com o parágrafo 1 desde que a mesma esteja listada e satisfaça as condições do Anexo II sobre Isenções ao Artigo II.

3. As disposições deste Acordo não devem ser interpretadas de forma a impedir que qualquer Membro conceda vantagens a países adjacentes destinadas a facilitar o intercâmbio de serviços produzidos e consumidos localmente em zonas de fronteira contígua." 
Alguns pontos relevantes em relação à regra do artigo II:1 devem ser ressaltados ${ }^{400}$ :

(i) A regra aplica-se a qualquer medida coberta pelo acordo, devendo o membro conferir "tratamento" ${ }^{401}$ não menos favorável do que aquele concedido a qualquer outro país;

(ii) "Qualquer outro país" inclui o tratamento mais favorecido dado a não membros da OMC.

(iii) $\mathrm{O}$ tratamento deve ser concedido imediata e incondicionalmente, o que significa que o direito ao tratamento mais favorável pode ser exigido logo que seja conferido a qualquer outro país e independentemente de qualquer condição imposta ao outro país para o gozo do tratamento mais favorável;

(iv) $\mathrm{O}$ tratamento deve ser entre serviços ou prestadores de serviços similares.

O termo "medidas" utilizado no parágrafo 1 é definido pelo artigo XXVIII(a) como "qualquer medida adotada por um Membro, seja em forma de lei, regulamento, regra, procedimento, decisão, decisão administrativa, ou sob qualquer outra forma." Regras de tributação sobre a renda enquadram-se neste conceito.

Ademais, o artigo II aplica-se a serviços e seus prestadores, o que faz com que, nos moldes apresentados no tópico IV.2.1 supra, ele abranja a tributação da renda.

Deste modo, a tributação da renda é abrangida pelo artigo II do GATS, a não ser que alguma exceção se aplique, conforme veremos a seguir.

\footnotetext{
${ }^{400}$ FALZON, Franco, Most-favored-nation treatment in the GATS and its effect on direct taxation, in J. Herdin-Winter, I. Hofbauer, The relevance of WTO law for tax matters, Wien, Linde, 2006, p. 127.

${ }^{401}$ Saliente-se que "tratamento" é termo mais amplo do que os termos "qualquer vantagem, favor, imunidade ou privilégio" utilizados no artigo I:1 do GATT. O tratamento, no GATS, se aplica em relação a qualquer medida coberta pelo acordo. Ainda, conforme decisão do Órgão de Apelação no caso European Communities - Regime for the Importation, Sale and Distribution of Bananas, WT/DS27/AB/R, parágrafo 233, página 94, o "tratamento menos favorecido" abrange a discriminação de direito e de fato.
} 


\section{IV.2.3.2. Exceções}

A aplicação do Tratamento da Nação Mais Favorecida do GATS à tributação da renda deve ser vista à luz das exceções a esta regra.

A primeira exceção relevante é aquela constante do artigo II:1, que determina que a regra não se aplicará aos casos em que o membro indique expressamente a exceção em anexo específico, dentro dos moldes do Anexo II do GATS. Trata-se das listas negativas de exceções à regra da Nação Mais Favorecida que já mencionamos anteriormente.

Os Estados Unidos possuem ampla lista de exceções de medidas tributárias aplicáveis a todos os setores ${ }^{402}$, a qual exclui grande parte das medidas de tributação da renda ${ }^{403}$ deste país da aplicação do artigo II do $\operatorname{GATS}^{404}$.

Por outro lado, nenhum dos itens da lista de exceções brasileira ${ }^{405}$ exclui qualquer medida de tributação da renda da aplicação do artigo II.

As outras exceções são aquelas constantes das alíneas do artigo XIV do GATS. Verificamos no tópico IV.2.2.2 supra que tais exceções devem ser aplicadas em conformidade com a ressalva constante do caput deste artigo.

Ademais, estabelecemos no tópico IV.2.2.1 supra que é defensável que as exceções previstas nas alíneas (a) e (c)(1) do artigo XIV apliquem-se à tributação da renda, de modo a permitir medidas que, apesar de contrariarem as regras do GATS, prestem-se a (i) garantir a coerência do sistema tributário; (ii) evitar a evasão e a elisão; e (iii) viabilizar a fiscalização e aplicação das normas tributárias. Novamente, tais justificativas são limitadas em seu escopo pelo próprio caput do artigo XIV.

\footnotetext{
${ }^{402}$ United States of America, Final List of Article II (MFN) Exemptions, GATS/EL/90, 15 de abril de 1994, pp. $2-11$.

${ }^{3}$ Dentre os itens, temos: "measures permitting less favorable taxation for citizens, corporations or products of a foreign country based on discriminatory or extraterritorial taxes, more burdensome taxation, or other discriminatory conduct."

${ }^{404}$ GROSS, Jakob B., OECD defensive measures against harmful tax competition legality under WTO, in INTERTAX, v. 31, issue 11, 2003, p. 397. THIEL, Servaas van, General report, in LANG, Michael, HERDIN, Judith, HOFBAUER, Ines (org.), WTO and direct taxation, Kluwer Law, 2005, p. 36

${ }^{405}$ Brazil - Final List of Article II (MFN) Exemptions, GATS/EL/13.
} 
Resta analisar a exceção constante da alínea (e) do artigo XIV, aplicável especificamente à regra do Tratamento da Nação Mais Favorecida constante do artigo II. Nesses termos, o artigo XIV(e) dispõe que não deverá ser impedida a aplicação de medidas "incompatíveis com o Artigo II, sempre que a diferença de tratamento resulte de um acordo destinado a evitar a dupla tributação ou de disposições destinadas a evitar a dupla tributação contidas em qualquer outro acordo ou convênio internacional pelo qual o Membro esteja vinculado."

A primeira pergunta que se deve fazer em relação a esta exceção é se ela tem o condão de retirar qualquer tipo de medida de tributação da renda do escopo de aplicação do artigo II do GATS.

Poder-se-ia defender, por exemplo, que a exceção visa a excluir medidas de tributação da renda que tipicamente se encontram em acordos de bitributação. Como a extensão de matérias cobertas por acordos de bitributação é grande, esta interpretação tornaria o artigo II praticamente inaplicável à tributação da renda.

Todavia, acreditamos que a redação do artigo XIV(e) não permite esta interpretação e que não é este o objetivo visado por este dispositivo.

Em nossa visão, a finalidade da exceção da alínea (e) é respeitar a repartição de competência negociada entre dois Estados por meio de um acordo de bitributação, evitando que, por meio da aplicação da regra da Nação Mais Favorecida, as concessões negociadas nestes acordos bilaterais estendam-se a países que não são partes do acordo e que, portanto, não fizeram qualquer concessão em relação à sua competência tributária.

A redação da alínea (e) reforça este entendimento, pois parece ser clara a excepcionar apenas a diferença de tratamento resultante de um acordo destinado a evitar a dupla tributação ou de outro acordo internacional.

Logo, se a diferença de tratamento resultar da aplicação da lei interna de um país, independentemente de qualquer acordo de bitributação, ela não será excepcionada e o artigo II deve ser aplicado. 
Ainda, esta interpretação parece se coadunar melhor com a regra do caput do artigo XIV, que pede que as exceções sejam aplicadas da maneira mais restrita possível, de modo a não frustrar os objetivos do GATS ${ }^{406}$.

\section{IV.2.3.3. Possíveis casos}

A regra da nação mais favorecida tipicamente veda que o Estado anfitrião, ou seja, aquele que recebe serviço de outro Estado Membro (i.e., onde está o consumidor deste serviço), ou onde se encontra a filial ou subsidiária do prestador de serviços de outro Estado Membro, aplique aos serviços ou ao prestador de serviços deste outro Estado Membro tratamento menos favorável do que o tratamento aplicado a serviços ou prestadores similares de um terceiro Estado ${ }^{407}$.

Vejamos, nos tópicos a seguir alguns exemplos de medidas de tributação de tributação da renda que podem contrariar esta obrigação.

\section{IV.2.3.3.1. Similaridade}

Em primeiro lugar, é necessário determinar o conceito de similaridade, que, no âmbito do GATS, adquire sentido específico ${ }^{408}$. Em European Communities - Regime for the Importation, Sale and Distribution of Bananas ${ }^{409}$, o Painel sustentou que, para estabelecer a similaridade entre prestadores de serviços, deve-se considerar a similaridade entre os serviços prestados pelos prestadores comparados. Com base nesse raciocínio, o Painel concluiu que prestadores de serviços que prestem serviços similares devem ser considerados similares para efeitos de aplicação do artigo II:1 do GATS.

\footnotetext{
406 THIEL, Servaas van, General report, in LANG, Michael, HERDIN, Judith, HOFBAUER, Ines (org.), WTO and direct taxation, Kluwer Law, 2005, p. 37.

${ }^{407}$ Idem, ibidem, p. 36.

${ }^{408}$ FALZON, Franco, Most-favored-nation treatment in the GATS and its effect on direct taxation, in J. Herdin-Winter, I. Hofbauer, The relevance of WTO law for tax matters, Wien, Linde, 2006, p. 129.

${ }^{409} \mathrm{WT} / \mathrm{DS} 27 / \mathrm{R} / \mathrm{MEX}$, parágrafo 7.346.
} 
O Painel no caso Canada - Certain Measures Affecting the Automotive Industries ${ }^{410}$ ainda aponta que "para fins do caso em análise, os prestadores de serviço em questão devem ser considerados similares no que se refere à prestação dos mesmos serviços".

Se as decisões apontadas acima forem tomadas de forma excessivamente ampla, resultados indesejáveis podem surgir.

Com efeito, há serviços similares que podem ser prestados de forma bastante diversa. Serviços transfronteiriços de consultoria, por exemplo, podem ser prestados ao menos de dois modos diversos: (i) sem qualquer presença física da prestadora no país do consumidor; ou (ii) por meio de filiais ou subsidiárias da prestadora no país do consumidor. O resultado final do serviço, nesses casos, pode ser exatamente o mesmo (e.g., entrega de um relatório, parecer etc.), mas a forma de prestação é completamente diversa.

Não parece adequado concluir que os julgados mencionados acima autorizariam, pelo mero fato de o resultado do serviço ser o mesmo, a considerar similares prestadores de serviços de um país $\mathrm{C}$ que não têm qualquer presença física no país do consumidor (país A), com prestadores de um país B, que prestam os serviços por meio de subsidiárias no país A.

Em nossa visão, o modo pelo qual o prestador de serviços se estrutura para prestar tais serviços importa para a comparação de similaridade, ainda que o resultado final do serviço para o consumidor seja, bem ou mal, o mesmo. Se não fosse assim, o próprio artigo I do GATS não teria distinguido quatro modos diversos de prestação de serviços.

Entender de forma diversa, ao menos no que tange à tributação da renda, implicaria a obrigação de tratamento igual de situações claramente desiguais. Por exemplo, imaginemos que, no caso dos prestadores de serviços de consultoria apresentado acima, o país A tribute a renda da subsidiária do prestador de serviços do país $\mathrm{B}$, devido ao fato de

${ }^{410}$ WT/DS139/R, parágrafo 10.248 . 
tal subsidiária ser residente no país A. Por outro lado, o país A não tributaria a renda do prestador de serviços em $\mathrm{C}$, pois tal prestador não teria qualquer presença física em $\mathrm{A}^{411}$.

Neste caso, se entendermos que os prestadores são similares pelo mero fato de o resultado dos serviços ser similar, o país B, com base no artigo II do GATS, poderia exigir que A outorgasse ao seu prestador de serviços o mesmo tratamento que outorga ao prestador residente em C. Isso significaria que a renda da subsidiária do prestador de B não poderia ser tributada pelo país A.

O absurdo desta conclusão reside no fato de que, se o prestador de serviços do país C tivesse optado atuar em A por meio de uma subsidiária, ele seria tributado por $\mathrm{A}$ da mesma forma que o prestador de serviços de B. Ou seja, a legislação de A não favorece um país em relação ao outro. Ela simplesmente trata de forma diversa estruturas de prestação de serviço diversa, ainda que o resultado final do serviço seja similar. Não parece lógico entender que estas diferentes estruturas estejam em situações comparáveis.

Se o Brasil fosse o país anfitrião neste exemplo, haveria tratamento tributário diferenciado entre a subsidiária do prestador de B e o prestador de C. O Brasil tributaria a renda universal da subsidiária, considerando suas receitas e despesas, enquanto tributaria na fonte o rendimento bruto auferido pelo prestador de $\mathrm{C}$, desde que pago por um residente no Brasil.

Esta diferença de tratamento entre estruturas é natural a qualquer sistema de tributação da renda e, em nossa visão, não fere o artigo II do GATS, pois a diferença de tratamento não é feita em decorrência do país do prestador de serviços, mas da estrutura adotada pelo prestador para prestar tais serviços.

Uma possível solução para determinar a similaridade entre os prestadores seria segregá-los nos quatro modos de prestação de serviços previstos no artigo I:2 do GATS, considerando similares apenas os prestadores que prestam serviços no mesmo modo. Tal interpretação se coadunaria inclusive com a posição adotada pelos Painéis mencionados

\footnotetext{
${ }^{411}$ Consideremos que, para a legislação do país A, o mero pagamento de serviços por um residente de A para um prestador não residente que não tenha presença física em A não é suficiente para que A tribute na fonte a renda do prestador em C. Ainda, para todos os efeitos, suponhamos que não haja acordos de bitributação entre $\mathrm{A}$ e $\mathrm{C}$ ou entre $\mathrm{A}$ e $\mathrm{B}$, sendo que a diferença de tratamento decorrerá exclusivamente da legislação interna de $\mathrm{A}$.
} 
acima, pois se poderia defender que serviços que se enquadram em diferentes modos do artigo I:2 não são serviços similares.

Assim, a estrutura adotada pelo prestador de serviço é relevante para determinar prestadores similares. A discriminação vedada pelo artigo II do GATS não é a discriminação entre diferentes modos de prestação de serviços, mas entre prestadores de serviços de diferentes países em igual situação.

Superada esta questão, cumpre verificar possíveis situações em que a legislação de em Estado Membro poderia discriminar prestadores de países diferentes em igual situação. Nos tópicos a seguir analisaremos estes casos e verificaremos se há justificativas pertinentes para que haja a discriminação.

\section{IV.2.3.3.2. Preços de transferência}

Apontamos no tópico II.4.2 do Capítulo II supra que as regras de preços de transferência limitam a dedutibilidade, por empresas brasileiras, dos custos de produtos importados.

No caso brasileiro, estas regras também se aplicam às importações de serviços $^{412}$. Assim, a dedutibilidade das despesas de serviços importados por empresas brasileiras pode ser limitada pelas regras de preços de transferência.

De acordo com as regras brasileiras, a empresa residente no Brasil que tome serviços de prestadores no exterior estará sujeita aos ajustes de preços de transferência nas seguintes condições:

(i) Se o prestador de serviços no exterior não for residente em paraíso fiscal, haverá ajustes de preços de transferência se o prestador estrangeiro e a empresa brasileira tomadora dos serviços forem partes ligadas;

\footnotetext{
${ }^{412}$ Conforme prevê o artigo 18 da Lei no 9.430/96.
} 
(ii) Se o prestador de serviços no exterior for residente em paraíso fiscal, haverá ajustes de preços de transferência independentemente da existência de vínculo entre o prestador estrangeiro e a empresa brasileira tomadora dos serviços.

Desta forma, o Brasil discrimina prestadores de serviços em paraísos fiscais em relação aos prestadores de serviços fora de paraísos fiscais. Enquanto as importações de serviços advindos dos últimos somente estarão sujeitas a ajustes de preços de transferência na presença de vínculo entre as partes, as importações advindas dos primeiro sempre estarão sujeitas a tais ajustes.

Mostramos no tópico II.4.2.2 do Capítulo II supra que diversos países considerados paraísos fiscais pela legislação brasileira são membros da OMC.

Desta maneira, cabe indagar se tais países poderiam exigir, com base no artigo II do GATS, que o Brasil outorgasse a eles o mesmo tratamento que outorga aos Membros não qualificados como paraíso fiscal.

Ou seja, poderiam os paraísos fiscais membros da OMC exigir que o Brasil se abstivesse de aplicar as regras de preços de transferência nas importações de serviços por empresas brasileiras de prestador residente em paraíso fiscal quando tal prestador não fosse parte ligada à empresa brasileira ${ }^{413}$ ?

A resposta é afirmativa, a não ser que o Brasil possa justificar a discriminação com base no artigo XIV do GATS.

Vimos no tópico IV.2.2.1 supra deste Capítulo que as alíneas (a) e (c)(1) do artigo XIV podem ser invocadas para justificar medidas voltadas a combater a evasão e a elisão fiscal. Todavia, tais medidas devem ser aplicadas à luz da ressalva do caput do artigo XIV, conforme apresentado no tópico IV.2.2.2 supra.

\footnotetext{
${ }^{413}$ FALZON, Franco, Most-favored-nation treatment in the GATS and its effect on direct taxation, in J.
} Herdin-Winter, I. Hofbauer, The relevance of WTO law for tax matters, Wien, Linde, 2006, p. 132. 
No tópico II.4.2.2 do Capítulo II supra verificamos a fundamentação para a aplicação das regras de preços de transferência em transações com paraísos fiscais, mesmo na ausência de vínculo. Esta fundamentação aplica-se igualmente ao presente caso.

Sendo assim, as mesmas conclusões a que chegamos no tópico II.4.2.2 do Capítulo II supra aplicam-se neste caso.

Ou seja, parece haver justificativa para a aplicação das regras de preços de transferência, independentemente do vínculo entre importador e exportador, nos casos de exportadores residentes em paraísos fiscais que não permitem o acesso às informações sobre composição societária e titularidade das pessoas jurídicas neles residentes. Em relação aos paraísos fiscais que permitem tal acesso, a justificativa ficaria prejudicada.

\section{IV.2.3.3.3. Tributação de subsidiárias}

A legislação de um Estado Membro anfitrião pode, em determinados casos, tratar de modo discriminatório subsidiárias detidas por controladores de diferentes países.

Entendemos que, quando se tratar de subsidiárias no Estado Membro anfitrião controladas por prestadores de serviços de outro Estado Membro, o Estado anfitrião está sujeito à aplicação do Tratamento da Nação Mais Favorecida.

Por exemplo, o Estado Membro A permite que as subsidiárias nele residentes e controladas por empresas prestadoras de serviços do Estado B deduzam determinadas despesas, mas proíbe que as subsidiárias controladas por empresas prestadoras do Estado Membro $\mathrm{C}$ deduzam despesas similares. Neste caso, acreditamos que o Estado $\mathrm{C}$ poderia exigir, com base no Tratamento da Nação Mais Favorecida, que o Estado A permitisse a dedutibilidade destas despesas pelas subsidiárias detidas por empresas do Estado C.

O Brasil diferencia o tratamento de algumas despesas de subsidiárias brasileiras de empresas estrangeiras com base na residência do sócio estrangeiro. 
Tal diferenciação decorre da aplicação das chamadas regras de subcapitalização brasileiras, instituídas pela Medida Provisória $\mathrm{n}^{\circ}$ 472/09 e atualmente regidas pelos artigos 24 e 25 da Lei $n^{\circ} 12.249 / 10$.

Sem entrar em maiores detalhes acerca destas regras, deve-se apontar apenas que a sua finalidade é limitar a dedutibilidade dos juros pagos por pessoas jurídicas brasileiras referentes ao endividamento destas empresas com mutuários residentes no exterior.

Os artigos 24 e 25 da Lei $n^{\circ} 12.249 / 10$, ao estabelecer o limite dos juros dedutíveis, diferenciam os casos de juros pagos a residentes fora de paraísos fiscais dos casos de pagamentos a residentes em paraísos fiscais. O limite de dedutibilidade dos juros pagos a residentes em paraísos fiscais é mais baixo.

Isto significa que subsidiárias de prestadoras de serviços em paraísos fiscais, que se financiem com empréstimos de suas controladoras, são tratadas pelas regras brasileiras de tributação da renda de maneira mais gravosa do que as subsidiárias de prestadores de serviços fora de paraísos fiscais e que se financiem de maneira similar.

O conceito de paraíso fiscal utilizado pelos artigos 24 e 25 da Lei n ${ }^{\circ} 12.249 / 10$ é o dos artigos 24 e 24-A da Lei n 9.430/96, já analisados no tópico II.4.2.2 do Capítulo II supra, sendo que diversos membros da OMC se enquadram neste conceito.

Sendo assim, tais membros poderiam exigir, com base no artigo II do GATS, que o Brasil não aplicasse as regras mais gravosas de subcapitalização para as subsidiárias de prestadores de serviços neles residentes.

\section{IV.2.3.3.4. Tributação na fonte}

O Estado Membro anfitrião pode tributar na fonte os rendimentos de prestadores de serviços não residentes pagos por residentes do Estado anfitrião. 
O Brasil, por exemplo, exige que o a pessoa residente no Brasil retenha o imposto de renda na fonte à alíquota de $25 \%$ sobre as remessas para pagamentos de serviços prestados por não residentes ${ }^{414}$.

Se, ao impor este tipo de retenção na fonte, o Estado Membro anfitrião diferenciar a alíquota aplicável às remessas para prestadores de diferentes países, pode haver discriminação em relação ao artigo II do GATS, a não ser que a discriminação decorra da aplicação de acordo de bitributação.

Nesse sentido, um caso interessante narrado por Ureta $^{415}$ foi a tentativa de o Panamá de iniciar uma disputa contra o México sob o argumento que este país tributava na fonte os serviços prestados por empresas panamenhas de forma mais gravosa do que aqueles prestados por empresas de outros Estados Membros. A razão para a tributação mais gravosa era que o Panamá era listado como paraíso fiscal pela legislação mexicana.

Ureta aponta que o Panamá tentou usar a disputa como meio de encurralar o México - país membro da OCDE - a excluí-lo de sua lista de paraísos fiscais e, assim, ter um argumento contra a OCDE para não ter que submeter a carta de compromisso exigida por esta organização para que ela considerasse o Panamá como um paraíso físcal cooperativo. A estratégia falhou e o Panamá acabou apresentando a carta de compromisso em 2002. A disputa nunca chegou a ser julgada.

Uma segunda hipótese em que a tributação na fonte de remessas a não residentes estará sob o escopo de aplicação do GATS é aquela em que subsidiárias de prestadores de serviços estrangeiros realizarem pagamentos para as suas controladoras.

Vejamos o seguinte exemplo: o prestador de serviços residente no Estado Membro A tem uma subsidiária no Estado Membro B. Tal subsidiária faz pagamentos de juros e dividendos à sua controladora. Estes pagamentos, conforme mencionamos no tópico IV.2.1 supra estariam dentro do escopo de aplicação do GATS, pois decorrem da estrutura de prestação de serviços por meio de subsidiárias. Assim, o Estado Membro B

\footnotetext{
${ }^{414}$ Artigo 685, II, "a", do Decreto no 3.000/99 ("Regulamento do Imposto de Renda"), que tem por base legal o artigo 100 do Decreto-Lei $n^{\circ} 5.844 / 43$, o artigo 77 da Lei $n^{\circ} 3.470 / 58$, o artigo 28 da Lei ${ }^{\circ} 9.249 / 95$ e os $\operatorname{artigos} 7^{\circ}$ e $8^{\circ}$ da Lei $n^{\circ} 9.779 / 99$.

${ }^{415}$ URETA, Santiago Solórzano, National report Mexico, in WTO and Direct Taxation, LANG, Michael, HERDIN, Judith, HOFBAUER, Inês (coord.) Kluwer Law International, 2005, p. 481.
} 
não poderia aplicar a estes pagamentos tratamento menos favorável do que aquele aplicado a pagamentos de juros e dividendos de subsidiárias de prestadores de serviços de terceiros países, a não ser que o tratamento mais favorável a estes terceiros países decorra da aplicação de um acordo de bitributação.

O Brasil tributa na fonte as remessas de juros a não residentes, que não decorram de aplicações financeiras ou de investimentos de portfólio, à alíquota geral de $15 \%{ }^{416}$. Todavia, o artigo $8^{\circ}$ da Lei $n^{\circ} 9.779 / 99$ determina que, se o beneficiário dos rendimentos for residente em paraíso fiscal, a alíquota do imposto de renda retido na fonte aplicável é de $25 \%$.

Para fins de aplicação da alíquota de $25 \%$, aplica-se o conceito de paraíso fiscal veiculado pelo caput e pelo $\S 4^{\circ}$ do artigo 24 da Lei n ${ }^{\circ}$ 9.430/96. Assim, será paraíso fiscal o país:

(i) que não tribute a renda ou a tribute à alíquota máxima inferior a $20 \%$. Considera-se a legislação tributária do referido país, aplicável às pessoas físicas ou às pessoas jurídicas, conforme a natureza do ente com o qual houver sido praticada a operação; e/ou

(ii) cuja legislação não permita o acesso a informações relativas à composição societária de pessoas jurídicas, à sua titularidade ou à identificação do beneficiário efetivo de rendimentos atribuídos a não residentes.

Não se aplica, neste caso, o conceito de regime fiscal privilegiado veiculado pelo artigo 24-A da Lei $n^{\circ} 9.430 / 96$, por ausência de referência expressa a este conceito pelo artigo $8^{\circ}$ da Lei $n^{\circ} 9.779 / 99$.

$\mathrm{O}$ artigo $1^{\circ}$ da Instrução Normativa $\mathrm{n}^{\circ} 1.037$, de 4 de junho de 2010, traz lista dos países que se enquadram neste conceito, sendo que, conforme mencionado no tópico II.4.2.2 do Capítulo II supra, diversos países constantes desta lista são Membros da OMC.

\footnotetext{
${ }^{416}$ Artigo 702 do Regulamento do Imposto de Renda, que tem por base legal o artigo 100 do Decreto-Lei $\mathrm{n}^{\circ}$ 5.844/43, o artigo 77 da Lei ${ }^{\circ} 3.470 / 58$ e o artigo 28 da Lei ${ }^{\circ}$ 9.249/95.

${ }^{417}$ Artigo 685, II, "b" do Regulamento do Imposto de Renda, cuja base legal é o artigo $8^{\circ}$ da Lei no 9779/99.
} 
Nesses termos, parece que estes Estados poderiam exigir na OMC, com base no artigo II do GATS, que o Brasil cobrasse o imposto de renda na fonte à alíquota de $15 \%$, e não $25 \%$, sobre os pagamentos de juros de subsidiárias às suas controladoras, nos casos em que tais empresas são prestadoras de serviços.

O Brasil somente poderia aplicar o tratamento discriminatório se pudesse justificá-lo com base no artigo XIV do GATS.

Todavia, parece-nos difícil construir um argumento para defender que a diferenciação de alíquota aplicada pelo Brasil vise a evitar a evasão ou a elisão, seja necessária para a fiscalização, ou para manter a coerência do sistema tributário brasileiro.

Em nossa visão, a aplicação da alíquota majorada de retenção na fonte em remessas para paraísos fiscais decorre do entendimento de que, uma vez que estes países não tributam a renda dos seus residentes, beneficiários do rendimento em questão, cabe à fonte tributá-lo em sua inteireza, pois a parcela que não for tributada pela fonte não será tributada em nenhum país.

Em outras palavras, a aplicação da alíquota majorada de retenção na fonte é uma medida adotada pelo Brasil para evitar que haja a "dupla não tributação" do rendimento (i.e., o rendimento não seria tributado nem no seu Estado de fonte nem no Estado de residência do beneficiário).

Esta justificativa, todavia, não parece se enquadrar em nenhuma das alíneas do artigo XIV do GATS, razão pela qual acreditamos que a discriminação feita pelo Brasil poderia ser contestada no âmbito da OMC pelos Estados Membros qualificados como paraísos fiscais pela legislação brasileira. 


\section{IV.2.3.3.5. Acordos de bitributação}

Os acordos bilaterais para evitar a bitributação prestam-se a repartir ${ }^{418}$, entre os dois Estados signatários, a competência para tributar rendimentos que, por possuírem elementos de conexão com os dois Estados ${ }^{419}$, podem ser tributados por ambos.

Desta maneira, os acordos de bitributação possuem mecanismos que limitam a competência do Estado de fonte a tributar determinados rendimentos auferidos por residentes do outro Estado signatário. Ao mesmo tempo, os acordos obrigam o Estado de residência do contribuinte que aufere o rendimento a considerar o tributo que já foi recolhido ao Estado da fonte, evitando, assim, que haja bitributação sobre tal rendimento (seja por meio da outorga de crédito referente ao imposto recolhido na fonte, ou pela simples isenção do rendimento de fonte estrangeira).

Esta divisão de competências tributárias realizada pelos acordos de bitributação aplica-se no caso em que rendimentos são auferidos por um contribuinte residente em um dos Estados signatários, em relação aos rendimentos que o outro Estado possa tributar em conformidade com sua lei interna.

Ou seja, sendo o acordo de bitributação um acordo bilateral, ele se aplica nos casos em que haja pretensão conjunta de ambos os Estados signatárias a tributar a renda auferida por um contribuinte residente em um destes Estados.

Ademais, apesar de os acordos de bitributação seguirem uma estrutura relativamente padrão ${ }^{420}$, cada acordo decorre de negociações específicas entre os Estados contratantes e preverá diferentes regras de alocação de competência tributária entre Estado da fonte e Estado da residência.

\footnotetext{
418 AVI-YONAH, Reuven S., International Tax as International Law: An Analysis of the International Tax Regime, New York, Cambridge University Press, 2007, p. 169.

${ }^{419}$ SCHOUERI, Luis Eduardo, Princípios no Direito Tributário Internacional, Territorialidade, Fonte e Universalidade, in Roberto Ferraz (org.), Princípios e limites da tributação, São Paulo, Quartier Latin, 2005, p. 330.

${ }^{420}$ Estrutura esta que segue os Modelos da OCDE, ONU ou Estados Unidos, os quais em muito se assemelham. AVI-YONAH, Reuven S., Double Tax Treaties: an Introduction, in Karl P. Sauvant, Lisa E. Sachs (orgs.), The Effects of Treaties on Foreign Direct Investment: Bilateral Investment Treaties, Double Taxation Treaties and Investment Flows, Oxford, Oxford University Press, 2009.
} 
Por fim, para as situações em que não há um acordo de bitributação aplicável, a lei interna dos Estados aplica-se sem qualquer limitação ${ }^{421}$.

Logo, duas situações em que há a aplicação de dois acordos diversos serão tributadas de maneira diferente entre si. Ainda, situações em que não há a aplicação de qualquer acordo de bitributação serão tratadas de maneira diversas daquelas em que há tal aplicação.

Por exemplo, a lei brasileira determina que os pagamentos de juros de uma subsidiária brasileira à sua controladora no exterior (fora de paraíso fiscal) estão sujeitos à tributação na fonte, pelo Brasil, à alíquota de 15\%. Na ausência de qualquer acordo de bitributação aplicável, será esta a alíquota que o Brasil aplicará para a tributação destes rendimentos.

Todavia, se a referida controladora for residente em Israel, aplicar-se-á o acordo de bitributação firmado entre Brasil e Israel, que limita à alíquota de $10 \%$ a tributação na fonte de rendimentos de juros. Sendo assim, a alíquota máxima de retenção na fonte que o Brasil pode impor sobre rendimentos pagos por uma subsidiária brasileira à sua controladora em Israel é $10 \%$.

O acordo entre o Brasil e a África do Sul, por sua vez, permite que o país da fonte tribute os juros à alíquota de até $15 \%$. Sendo assim, se a controladora da subsidiária brasileira fosse residente na África do Sul, o Brasil poderia tributar os juros na fonte à alíquota de $15 \%$.

Estes exemplos mostram que controladoras residentes em países diferentes seriam tributadas na fonte pelo Brasil de forma diversa em relação aos rendimentos de juros pagos por suas subsidiárias. Esta diferença de tratamento pode ocorrer em decorrência da aplicação de acordos de bitributação diversos, ou simplesmente da ausência da aplicação de qualquer acordo.

Conforme vimos, se a controladora e subsidiária mencionadas nestes exemplos forem prestadoras de serviço (e o pagamento de juros decorrer do investimento da

${ }^{421}$ SCHOUERI, Luís Eduardo, Tratados e convenções internacionais sobre tributação, in RDTA no 17, 2003, p. 35. 
controladora na subsidiária para a prestação de serviços no modo previsto no artigo I:2(c) do GATS) o GATS pode ser aplicável.

Sendo assim, se não houvesse qualquer ressalva para a regra do Tratamento da Nação Mais Favorecida, poder-se-ia entender que o tratamento diferenciado da tributação na fonte dos rendimentos auferidos pelas controladoras dos exemplos acima seria vedado, devendo o Brasil aplicar para todas as remessas a alíquota de imposto de renda aplicável à nação mais favorecida (no caso, Israel).

No entanto, a exceção do artigo XIV(e) do GATS impede que se chegue a esta conclusão ao prever que não deverá ser impedida a aplicação de medidas incompatíveis com o Artigo II, sempre que a diferença de tratamento resulte de um acordo destinado a evitar a dupla tributação.

A exceção em tela parece reconhecer que os acordos de bitributação dividem bilateralmente as competências tributárias entre dois Estados, sendo que as regras de cada acordo representam os resultados de concessões mútuas negociadas entre os dois Estados.

Estender as concessões que um Estado fez no âmbito de um acordo de bitributação a terceiros países permitiria que estes países gozassem de um tratamento favorável sem dar nada em troca.

O GATS parece dobrar-se a este raciocínio ao excepcionar os acordos de bitributação da aplicação do Tratamento da Nação Mais Favorecida.

\section{IV.2.4 Tratamento nacional}

O artigo XVII do GATS traz a obrigação de tratamento nacional aos serviços e prestadores de serviços dos Estados Membros nos seguintes termos:

"Nos setores inscritos em sua lista, e salvo condições e qualificações ali indicadas, cada Membro outorgará aos serviços e prestadores de serviços de qualquer outro Membro, com respeito a todas as medidas que afetem a prestação de serviços, um tratamento não menos favorável do que aquele que 
dispensa a seus próprios serviços similares e prestadores de serviços similares."

$\mathrm{O}$ primeiro ponto que se deve notar em relação à obrigação de tratamento nacional do GATS é que ela se aplica apenas nos casos em que os Estados Membros assumiram compromissos expressos de liberalização de acesso a mercado e não realizaram quaisquer ressalvas à aplicação do tratamento nacional $^{422}$.

Tais compromissos, que se encontram em anexos específicos de cada Membro, não necessariamente incluem todos os setores de serviços e podem prever exclusões expressas da aplicação do Tratamento Nacional a medidas tributárias. ${ }^{423}$

O segundo ponto relevante é que o artigo XIV(d) excepciona da aplicação do Tratamento Nacional medidas que tenham "por objetivo assegurar a imposição ou coleta equitativa ou efetiva de impostos diretos em relação a serviços ou prestadores de serviços de outros Membros."

A nota de rodapé $n^{\circ} 6$ à alínea (d) do artigo XIV esclarece que tais medidas incluem as medidas adotadas por um Membro, ao amparo de seu regime fiscal, que:

(i) apliquem-se a prestadores de serviços não residentes em reconhecimento ao fato de que a obrigação fiscal dos não residentes é determinada com respeito aos itens tributáveis cuja fonte ou localização se faça no território do Membro; ou

(ii) -apliquem-se a não residentes a fim de assegurar a imposição ou coleta de tributos no território do Membro; ou

(iii) apliquem-se a residentes ou não residentes a fim de impedir a evasão ou a fraude fiscal, incluindo-se medidas de execução; ou

(iv) apliquem-se aos consumidores de serviços prestados dentro ou a partir do território de outro Membro a fim de assegurar a imposição ou coleta

\footnotetext{
${ }^{422}$ OLSEN, Monroe, GATS - National treatment and taxation, in HERDIN-WINTER, Judith, HOFBAUER, Ines (org.), The relevance of WTO law for tax matters, Wien, Linde, 2006, p. 116.

${ }^{423}$ THIEL, Servaas van, General report, in LANG, Michael, HERDIN, Judith, HOFBAUER, Ines (org.), WTO and direct taxation, Kluwer Law, 2005, p. 38.
} 
de tributos de tais consumidores derivados de fontes situadas no território do Membro; ou

(v) estabeleçam distinção entre prestadores de serviços sujeitos a impostos sobre itens tributáveis em nível mundial de outros prestadores de serviços, em reconhecimento à diferença existente entre os mesmos quanto à natureza da base impositiva; ou

(vi) determinem, atribuam ou repartam rendas, lucros, ganhos, perdas, deduções ou crédito de pessoas residentes ou sucursais, ou entre pessoas vinculadas ou sucursais de uma mesma pessoa, a fim de salvaguardar a base impositiva do Membro.

Por fim, o artigo XXII:3 do GATS, ao disciplinar as consultas entre os Membros, prevê que:

"Nenhum Membro poderá invocar o Artigo XVII, seja em virtude do presente Artigo ou do Artigo XXIII, com respeito a uma medida de outro Membro que esteja compreendida no âmbito de um acordo internacional entre ambos destinado a evitar a dupla tributação. Em caso de desacordo quanto ao fato de tal medida estar ou não compreendida em dito acordo entre ambos, qualquer um dos Membros poderá trazer o assunto perante do Conselho para o Comércio de Serviços. O Conselho submeterá a questão a arbitragem. A decisão do árbitro será definitiva e mandatória para os Membros."

O grande número de exceções apontadas acima mostra que a aplicação, sem quaisquer ressalvas, do Tratamento Nacional do GATS à tributação da renda poderia trazer sérias consequências.

Isto ocorre por três motivos. Primeiro, a regra de tratamento nacional abrange prestadores de serviços, que são contribuintes dos tributos sobre a renda. Segundo, o artigo I do GATS abrange o investimento direto como modo de prestação de serviços. Terceiro, as regras de tributação da renda não tratam residentes e não residentes - e os seus respectivos investimentos - da mesma forma. 
Assim, se, em virtude da aplicação da regra de Tratamento Nacional do GATS, prestadores de serviços não residentes tivessem que ser tratados, para fins de tributação da renda, da mesma maneira que prestadores de serviços residentes, haveria profunda incompatibilidade entre os sistemas de tributação da renda de todos os Estados Membros e as obrigações assumidas no GATS.

Nesses termos, para evitar tal resultado, as exceções mencionadas acima buscam eliminar da aplicação do tratamento nacional as medidas de tributação da renda tipicamente voltadas a realizar a adequada tributação de residentes e não residentes.

Os itens mencionados na Nota de Rodapé $\mathrm{n}^{\circ} 6$ ao artigo XIV(d) do GATS confirmam que a tributação na fonte dos prestadores de serviços não residentes não é discriminatória, assim como não o seria a tributação da renda dos residentes em bases universais. Ainda, os ajustes de preços de transferência entre partes ligadas são expressamente aceitos.

Por fim, o artigo XXII:3 reforça qualquer medida de tributação da renda que esteja prevista em um acordo de bitributação entre os Estados-membros está fora dos escopo do Tratamento Nacional.

Contudo, é necessário recordar que as exceções previstas no artigo XIV(d) devem ser lidas em conjunto com a ressalva do caput deste artigo, analisada no tópico IV.2.2.2 supra.

Apesar de não haver qualquer posicionamento jurisprudencial na OMC que nos permita verificar exatamente qual seria papel do caput em limitar esta exceção específica, cremos que as medidas especificamente enumeradas na Nota de Rodapé $n^{\circ} 6$, como foram expressamente aceitas pelos Estados Membros ao firmarem o GATS, dificilmente poderiam ser contestadas à luz do caput do artigo XIV.

Isso não significa, todavia, que não seja possível encontrar exemplos de medidas de tributação da renda que poderiam ferir a obrigação de Tratamento Nacional do GATS. 
Regras de tributação da renda que vinculem um benefício tributário à utilização de serviços nacionais em detrimento de serviços importados (i.e., regras de conteúdo local semelhantes às regras aplicáveis a produtos que observamos no tópico II.4.1 do Capítulo II supra), por exemplo, poderiam ser consideradas contrárias ao artigo XVII do GATS, desde que o Estado Membro em questão tenha se comprometido a aplicá-lo ao serviço em questão.

\section{IV.2.5 Subsídios}

Conforme mencionado anteriormente, a disciplina de subsídios do ASMC aplica-se apenas a produtos, e não a serviços. O GATS conta com regras próprias referentes a subsídios no seu artigo $\mathrm{XV}$, nos seguintes termos:

"1. Os Membros reconhecem que, em determinadas circunstâncias, os subsídios podem ter efeitos de distorção do comércio de serviços. Os Membros manterão negociações com vistas à elaboração de disciplinas multilaterais necessárias para evitar estes efeitos de distorção. As negociações examinarão também a procedência das medidas compensatórias. Em tais negociações será reconhecida a função dos subsídios nos programas de desenvolvimento dos países em desenvolvimento e tomadas em conta a necessidade de flexibilidade que os Membros, em particular os Membros em desenvolvimento, tenham nesta área. Para fins de tais negociações, os Membros intercambiarão informações sobre todos os subsídios relacionados ao comércio de serviços que outorguem aos prestadores de serviços nacionais.

2. Todo Membro que se considere desfavoravelmente afetado por um subsídio de outro Membro poderá solicitar consultas a respeito com o outro Membro. Tais solicitações deverão ser examinadas com compreensão."

Vemos que, em seu atual estado, as regras do GATS não estabelecem qualquer disciplina efetivamente aplicável aos subsídios no setor de serviços ${ }^{424}$. Elas apenas indicam

${ }^{424}$ AHUJA, Rajeev, Towards developing subsidy disciplines under GATS, New Delhi, 2005, disponível [on line] in http://www.icrier.org/pdf/WP174.pdf [31.01.2011], p. 7. 
linhas de guia para futuras negociações acerca de tais medidas, nas quais deverá ser reconhecido que os subsídios, por um lado, podem distorcer o comércio de serviços e, por outro lado, têm função importante nos programas de desenvolvimento dos países em desenvolvimento.

Celli $^{425}$ aponta que houve pouco progresso até o momento nas discussões do Grupo de Trabalho sobre Regras do GATS no tocante aos subsídios. Segundo a Declaração Ministerial de Hong Kong, os Membros deverão intensificar seus esforços relacionados à regulamentação dos subsídios e engajar-se em discussões mais objetivas acerca de propostas dos Membros, inclusive quanto à elaboração de um possível conceito de subsídios (working definition) no âmbito do comércio de serviços.

Em face de tudo que foi exposto no Capítulo III supra, não há dúvidas que regras de tributação da renda podem veicular subsídios, sendo perfeitamente possível que tais subsídios apliquem-se também ao setor de serviços.

Todavia, tendo em vista as peculiaridades atinentes ao setor de serviços, não é claro o modo pelo qual tais subsídios poderiam ser disciplinados no âmbito do GATS, nem se as regras do ASMC relativas à tributação da renda poderiam ser utilizadas.

\section{IV.3. GATS, tributação da renda e subvenções tributárias}

O fato de o GATS abranger casos de prestação de serviços por investimentos diretos e prever a aplicação de suas cláusulas de Tratamento da Nação Mais Favorecida e Tratamento Nacional a prestadores de serviços poderia ter ampliado muito o seu escopo em relação às medidas de tributação da renda abrangidas.

Se não fossem as exceções constantes do artigo XIV, este acordo poderia afetar elementos essenciais da tributação da renda, como, por exemplo, o tratamento diferenciado entre residentes e não residentes e a alocação de competências tributárias decorrente dos acordos de bitributação.

\footnotetext{
${ }^{425}$ CELLI JUNIOR, Umberto, Os acordos de serviços (GATS) e de investimentos (TRIMs) na OMC: espaço para políticas de desenvolvimento (2006) disponível [on-line] in http://www.usp.br/prolam/downloads/gats.pdf [15.01.2011], p. 8.
} 
Ou seja, a interação do GATS com a tributação da renda iria muito além das subvenções tributárias, se não houvesse as exceções do artigo XIV.

Isto é uma decorrência das peculiaridades do comércio internacional de serviços (apontadas no tópico IV.1 supra), que funciona de acordo com lógica bastante diversa daquela aplicável ao comércio de produtos.

O setor de serviços não depende da passagem de bens pela fronteira dos Estados, como ocorre com o comércio de produtos. A prestação internacional de serviços pode se dar das mais diversas formas, inclusive por meio de investimentos estrangeiros diretos.

Sendo assim, a lógica do "protecionismo de fronteira" apontada na Introdução deste trabalho não se aplica a este setor, pois medidas que realizem o "protecionismo de propriedade" também são capazes de afetar diretamente o comércio internacional de serviços.

Desta maneira, a aplicação de regras referentes à liberalização do comércio de serviços à tributação da renda teria o potencial para alcançar medidas adotadas pelos Estados Membros que iriam muito além das subvenções fiscais.

Dito de outra forma, uma vez que a política de liberalização alcança algo mais do que o mero "protecionismo de fronteira", a linha das subvenções fiscais para de ser suficiente para distinguir as medidas de tributação da renda que conflitam com tais objetivos de liberalização.

A solução adotada pelo GATS para lidar com este dilema foi a adoção, nas alíneas (d) e (e) do artigo XIV, de regras expressas que excluem da aplicação das regras de Tratamento Nacional e Nação Mais Favorecida do acordo certos aspectos fundamentais da tributação da renda.

Tais exceções limitam sensivelmente a aplicação do GATS aos tributos sobre a renda. Nesses termos, os exemplos analisados mostram que Tratamento Nacional poderia aplicar-se a determinadas medidas de conteúdo local que privilegiem serviços nacionais em detrimento de importados e o Tratamento da Nação Mais Favorecida a medidas que 
tratem de maneira menos favorável os prestadores de serviços de determinados Membros da OMC (geralmente, medidas voltadas a combater a utilização de paraísos fiscais). 


\section{CONCLUSÕES}

A análise do GATT, do Acordo TRIMS, do ASMC e do GATS realizada neste trabalho mostrou que todos estes acordos aplicam-se a determinadas medidas de tributação da renda.

Tendo em vista que o GATT, o Acordo TRIMS e o ASMC lidam exclusivamente com o comércio internacional de produtos, as medidas vedadas por estes acordos são aquelas capazes de realizar o chamado "protecionismo de fronteira" 426 (i.e., aquelas medidas que agem como tarifas, discriminando produtos nacionais e importados, ou produtos importados entre si).

Verificamos que as medidas de tributação da renda podem realizar este tipo de protecionismo nos casos em que se relacionarem com produtos. Em tais casos, a fruição de determinadas vantagens pode ser atrelada à utilização de certos produtos pelo contribuinte, ou um benefício tributário pode ser dado a uma categoria específica de produtores, de modo a constituir um subsídio.

A análise realizada no Capítulo I deste trabalho mostra que estas medidas podem ser consideradas efetivas subvenções veiculadas por meio de normas de tributação da renda. Contudo, também verificamos naquele capítulo que a identificação destas subvenções não é simples.

Uma vez que as subvenções tributárias caracterizam-se como renúncias de receitas fiscais, a sua identificação requer a determinação de um sistema tributário parâmetro, sendo as subvenções caracterizadas como normas que desviam de tal parâmetro.

Verificamos, nos Capítulos II e III, que as regras do GATT, do Acordo TRIMS e do ASMC aplicam-se a subvenções tributárias capazes de: (i) discriminar produtos

\footnotetext{
${ }^{426}$ Ver Introdução.
} 
nacionais e importados; (ii) discriminar produtos importados entre si; ou (iii) veicular subsídios específicos a produtores nacionais.

Nesses termos, a aplicação das regras destes acordos aos tributos sobre a renda requer a identificação das subvenções veiculadas por estes tributos. Isso implica que todas as dificuldades atinentes à identificação das subvenções tributárias apontadas no Capítulo I terão de ser enfrentadas no âmbito da OMC.

Com efeito, Brauner ${ }^{427}$ aponta que as seguintes premissas deveriam ser atendidas para que o Órgão de Solução de Controvérsias da OMC pudesse identificar subvenções veiculadas por meio de tributos sobre a renda e decidir se tais subvenções contrariam as regras da OMC: (i) cada país teria um sistema "normal" de tributação da renda facilmente identificável e incontroverso, que poderia ser usado como parâmetro; (ii) na maioria dos casos, seria fácil identificar os desvios do parâmetro, tarefa perfeitamente factível pelo Órgão de Solução de Controvérsias da OMC; (iii) os desvios da estrutura parâmetro já estariam incluídos no orçamento de subvenções tributárias de cada Estado membro, ou ao menos os Estados concordariam em produzir tais orçamentos usando um parâmetro "certo" (e incontroverso) e em usar este orçamento não apenas para fins de política interna, mas também para a conformidade com o regime de comércio internacional; (iv) não apenas se admite que um sistema parâmetro de tributação da renda possa ser identificado para cada país, mas que países diferentes possam ter diferentes sistemas parâmetro e que as disparidades entre eles não desestabilizará internamente o comércio internacional.

Todavia, a análise realizada no Capítulo I supra mostra que tais premissas não são necessariamente verdadeiras e que a identificação e análise das subvenções tributárias está sujeita a alto grau de subjetivismo e controvérsias.

Ademais, não há congruência entre os orçamentos de subvenções tributárias realizados pelos Estados Membros, o que mostra que tais documentos não se prestariam para informar adequadamente o Órgão de Solução de Controvérsias acerca das subvenções adotadas por estes Estados.

${ }^{427}$ BRAUNER, Yariv, International trade and tax agreements may be coordinated, but not reconciled, in Virginia Tax Review (2005), p. 292. 
Ainda, se os orçamentos de subvenções tributárias produzidos pelos Estados Membros passarem a ser tomados pelo Órgão de Solução de Controvérsias como base para a solução de controvérsias sobre medidas de tributação da renda, haverá o estímulo para os Membros mudarem a sua política na elaboração de tais orçamentos ${ }^{428}$. Como há grande margem de subjetividade na elaboração destes orçamentos, os Estados Membros poderiam passar a desenhar o seu parâmetro de modo a ocultar algumas subvenções que anteriormente ficariam explícitas.

Este tipo de conduta, por um lado, prejudicaria a análise do Órgão de Solução de Controvérsias e comprometeria a possibilidade de este órgão tomar os orçamentos de subvenções tributárias como base para as suas decisões. Por outro lado, comprometeria a função do orçamento para a conformação de políticas internas dos Estados Membros ${ }^{429}$. Tratar-se-ia, assim, de situação de dupla perda, sem qualquer ganho.

Por fim, os casos DISC e FSC/ETI mostram o quão complexa pode ser a identificação de uma subvenção tributária quando regras de tributação de fluxos internacionais de renda estão em jogo.

Não obstante, tais casos também mostram que é firme a adoção, pelo Órgão de Solução de Controvérsias, da lógica de que cada país tem um sistema tributário normativo "básico" que pode ser estabelecido como parâmetro para a análise de uma medida de tributação da renda específica, em relação à qual há a suspeita de ser uma subvenção tributária $^{430}$.

Em nossa visão, considerando as atuais regras do GATT, do Acordo TRIMS e do ASMC, não haveria a possibilidade de adoção de outro tipo de solução pelo Órgão de Solução de Controvérsias. Tais regras pedem que as normas de tributação da renda que veiculam subvenções sejam identificadas e analisadas à luz das obrigações de Tratamento Nacional, Nação Mais Favorecida e da regulamentação dos subsídios.

\footnotetext{
${ }^{428}$ BRAUNER, Yariv, International trade and tax agreements may be coordinated, but not reconciled, in Virginia Tax Review (2005), pp. 300-303.

${ }^{429}$ Pois tais orçamentos deixariam de refletir a realidade das subvenções do país, uma vez que a submissão do orçamento à OMC passaria a gerar um estímulo para os Estados "mentirem" em tais orçamentos.

${ }^{430}$ BRAUNER, Yariv, Direito do comércio internacional e acordos tributários, Trad. Port. Gustavo Gonçalves Vettori, in Direito Tributário Atual nº 23, São Paulo, Dialética, 2009.
} 
Desta forma, por mais criticável que seja o método para a identificação das subvenções tributárias, o Órgão de Solução de Controvérsias deve empenhar seus melhores esforços para aplicá-lo.

Brauner ${ }^{431}$, por entender que a identificação das subvenções tributárias pelo Órgão de Solução de Controvérsias nunca será adequada, chega a sugerir que as questões de tributação da renda sejam retiradas do escopo da OMC e tratadas em um novo acordo, que estabeleceria um foro multilateral independente voltado a lidar exclusivamente com questões de tributação da renda e, dentro do possível, compactuar-se com os princípios adotados na OMC.

Neste ponto, as considerações que fizemos no Capítulo IV sobre o GATS ganham importância.

Naquele capítulo, verificamos que a liberalização do setor de serviços não lida apenas com o "protecionismo de fronteira", mas envolve também o "protecionismo de capital". Isso é uma decorrência do fato de que a prestação internacional de serviços pode se dar das mais diversas formas, inclusive por meio de investimentos estrangeiros diretos.

Desta maneira, a aplicação de regras referentes à liberalização do comércio de serviços à tributação da renda teria o potencial para alcançar medidas adotadas pelos Estados Membros que iriam muito além das subvenções fiscais.

Todavia, o GATS se absteve de lidar com estas questões de tributação da renda por meio da sua exclusão expressa exceções das alíneas (d) e (e) do artigo XIV. A regra de subsídios constante do artigo XV deste acordo também é fraca e, em sua conformação atual, não é capaz de afetar medidas de tributação da renda.

Se, no futuro, a OMC pretender ampliar o seu âmbito de atuação e entender que tais questões devem ser abordadas para que se possa garantir o livre comércio de serviços, acreditamos que a constituição de um novo foro multilateral próprio a lidar com questões de tributação da renda seria a solução mais adequada.

431 BRAUNER, Yariv, National report The United States, in LANG, Michael, HERDIN, Judith, HOFBAUER, Ines (org.), WTO and direct taxation, Kluwer Law, 2005, p. 758. 
Se tal foro multilateral viesse a ser constituído, ele poderia abranger todas as questões atinentes à tributação da renda dos Estados Membros, inclusive aquelas que afetam o GATT, o Acordo TRIMS e o ASMC.

Foge ao escopo do preste trabalho analisar as vantagens e desvantagens envolvidas na criação deste foro multilateral. Todavia, acreditamos que a análise dos problemas envolvidos no tratamento da tributação da renda pela OMC feita nesta tese possibilitará que posteriores estudos lidem com esta questão. 


\section{BIBLIOGRAFIA}

AHUJA, Rajeev, Towards developing subsidy disciplines under GATS, New Delhi, 2005, disponível [on line] in http://www.icrier.org/pdf/WP174.pdf [31.01.2011].

ANDREWS, William D., Personal deductions in an ideal income tax, 86 Harv. L. Rev. 309 (1972), (reproduzido em CARON, Paul L., BURKE, Karen C. e McCOUCH, Grayson M.P. Federal Income Tax Anthology, Cincinnati, Ohio, Anderson, 1997, $2^{\text {a }}$ tiragem, 2003).

ANNAND, Mel, Buckingham, Donald F., Kerr, William, A., Export subsidies and the World Trade Organization, 2001, disponível [on line] in www.esteycentre.ca/export_subsidies.htm [23-10-2005].

AULT, Hugh J., ARNOLD, Brian J., Comparative Income Taxation: a structural analysis, $2^{\mathrm{a}}$ ed., New York, Aspen Publishers, 2004

AULT, Hugh J., Corporate Integration, Tax Treaties, and the Division of the International Tax Base: Principles and Practices, Boston College Law School Research Paper 1992-02, 1992, disponível [on-line] in http://ssrn.com/abstract=916352.

ÁVILA, Humberto, Sistema constitucional tributário, São Paulo, Saraiva, 2004

AVI-YONAH, Reuvem S., SLEMROD, Joel, (How) should trade agreements deal with income tax issues?, disponível [on line] in www.law.umich.edu/centersandprograms/olin/papers.htm [=http://papers.ssrn.om/abstract=285345] [23.10.2005].

AVI-YONAH, Reuvem S., The interaction of tax, trade and investment, in Ad Hoc group of experts on international cooperation in tax matters, eleventh meeting, United Nations (documento ST/SG/AC.8/2003/L.4), Geneva, 2003, disponível [on line] in www.un.org [23.10.2005].

AVI-YONAH, Reuven S., Double Tax Treaties: an Introduction, in Karl P. Sauvant, Lisa E. Sachs (orgs.), The Effects of Treaties on Foreign Direct Investment: Bilateral Investment Treaties, Double Taxation Treaties and Investment Flows, Oxford, Oxford University Press, 2009 
AVI-YONAH, Reuven S., International Tax as International Law: An Analysis of the International Tax Regime, New York, Cambridge University Press, 2007.

AVI-YONAH, Reuven S., The Rise and Fall of Arm's Length: a Study in the Evolution of U.S. International Taxation, John M. Olin Center for Law\&Economics, Working Paper $\quad \mathrm{n}^{\mathrm{o}} \quad 92, \quad$ disponível $\quad$ [on-line] in www.law.umich.edu/centersandprograms/onlin/papers.htm [30.07.09].

AVI-YONAH, Reuven S., The WTO, Export Subsidies and Tax Competition, in WTO and Direct Taxation, LANG, Michael, HERDIN, Judith, HOFBAUER, Ines (coord.) Kluwer Law International, 2005.

BAKIJA, Jon, SLEMROD, Joel, Taxing ourselves: a citizen's guide to the debate over taxes, $3^{\text {a }}$ ed., MIT Press, Cambridge, 2004.

BAO, Lingguang, The WTO accession and tax policy options in China, in INTERTAX, v. 29, issue 8/9, 2001, pp. 283-296.

BARKER, William B., Optimal International Taxation and Tax Competition: Overcoming the Contradictions, in Northwestern Journal of International Law and Business, v. 22, 2001-2002.

BELSUNCE, Horacio A. García, El concepto de rédito en la doctrina y en el derecho tributario, Depalma, Buenos Aires, 1967.

BENSHALOM, Ilan, A Comprehensive Solution for a Targeted Problem: a Critique of the EU's Home State Taxation and CCCTB Initiatives, Northwestern University School of Law Public Law and Legal Theory Series $\mathrm{n}^{\circ}$ 08-21, disponível [on-line] in http://ssrn.com/abstract=1153579.

BENSHALOM, Ilan, The New Poor at Our Gates: Global Justice Implications for International Trade and Tax Law, NYU Law Rev., v. 85, n. 1, 2010, disponível [online] http://www.law.nyu.edu/ecm_dlv1/groups/public/@nyu_law_website_journals_la w_review/documents/documents/ecm_pro_065472.pdf.

BITTKER, Boris I., Accounting for federal "tax subsidies" in the national budget, in 22 Nat'l Tax J. 244 (1969) (reproduzido em CARON, Paul L., BURKE, Karen C. e McCOUCH, Grayson M.P. Federal Income Tax Anthology. Cincinnati, Ohio: Anderson1997. $2^{\mathrm{a}}$ tiragem) 2003, pp.303-306. 
BLIACHERIENE, Ana Carla, Subsídios: efeitos, contramedidas e regulamentação - uma análise das normas nacionais e das normas da OMC, in TORRES, Heleno Taveira (org.), Direito Tributário Internacional Aplicado, São Paulo, Quartier Latin, 2007.

BLOCK, Neal, CONNORS, Peter, The extraterritorial income exclusion regime increases scope of export incentives, in INTERTAX, v. 29, issue 8/9, 2001, pp. 301-305.

BRAUNER, Yariv, An International Tax Regime in Crystallization: Realities, Experiences, and Opportunities, New York University School of Law Working Paper Series, Research Paper $n^{\circ}$ 43, 2002, disponível [on-line] in www.ssrn.com/abratract_id=315685 [30.07.09].

BRAUNER, Yariv, Direito do comércio internacional e acordos tributários, Trad. Port. Gustavo Gonçalves Vettori, in Direito Tributário Atual $n^{o} 23$, São Paulo, Dialética, 2009.

BRAUNER, Yariv, Integration in an Integrating World, disponível [on-line] in http://papers.ssrn.com/sol3/papers.cfm?abstract_id=670441 [30.07.09].

BRAUNER, Yariv, International trade and tax agreements may be coordinated, but not reconciled, in Virginia Tax Review (2005), pp. 290-291.

BRAUNER, Yariv, National report The United States, in LANG, Michael, HERDIN, Judith, HOFBAUER, Ines (org.), WTO and direct taxation, Kluwer Law, 2005.

BRITO FILHO, Washington Juarez de, O GATT como norma de direito internacional tributário, in TORRES, Heleno Taveira (org.), Direito Tributário Internacional Aplicado Volume IV, São Paulo, Quartier Latin, 2007.

BROWN, Colin, Tax expenditures in Australia, in SWIFT, Zhicheng Li, BRIXI, Hana Polackova, VALENDUC, Christian (orgs.), Tax expenditures - shedding light on government spending through the tax system, Washington DC, The World Bank, 2004.

CASELLA, Paulo Borba, União Européia: instituições e ordenamento jurídico, São Paulo, LTr, 2002.

CELLI JUNIOR, Umberto, Os acordos de serviços (GATS) e de investimentos (TRIMs) na OMC: espaço para políticas de desenvolvimento (2006) disponível [on-line] in http://www.usp.br/prolam/downloads/gats.pdf [15.01.2011]. 
CHANCELLOR, Thomas, Imputed Income and the Ideal Income Tax, 67 Or. L. Rev. 561 (1988) (reproduzido em CARON, Paul L., BURKE, Karen C. e McCOUCH, Grayson M.P. Federal Income Tax Anthology. Cincinnati, Ohio: Anderson1997. 2a tiragem), 2003., pp. 142-149.

COSTA, José Augusto Fontoura, Decidir e julgar: um estudo multidisciplinar sobre a solução de controvérsias na Organização Mundial do Comércio, Tese de Titularidade apresentada na Faculdade de Direito da USP, São Paulo, 2009.

DALY, Michael, The WTO and direct taxation, 2005, disponível [on line] in http://www.wto.org/english/res_e/booksp_e/discussion_papers9_e.pdf [23-10-2010].

DECEREUX, Michael P., Business Taxation in a Globalized World, in Oxford Review of Economic Policy, v. 24, n 4, 2008, pp. 625-638.

DESAI, Mihir A., HINES Jr., James R., Evaluating International Tax Reform, Haward NOM Research Paper $n^{\circ}$ 03-48, 2003, disponível [on line] in http://ssrn.com/abstract=425943 [30.07.09]

DESAI, Mihir A., HINES Jr., James R., Old Rules and New Realities: Corporate Tax Policy in a Global Setting, Ross School of Business Working Paper n ${ }^{\circ}$ 920, 2004, disponível [on-line] in www.ssrn.com/abstract=606222 [30.07.09].

DESAI, Mihir A., HINES Jr., James R., The uneasy marriage of export incentives and the income tax, Cambridge-MA, 2000, disponível [on-line] in www.nber.org/papers/w8009 [23.10.2005].

DESAI, Mihir A., Securing Jobs or the New Protectionism?:Taxing the Overseas Activities of Mutionational Firms, disponível [on line ] in http://www.hbs.edu/research/pdf/09107.pdf e http://papers.ssrn.com/sol3/papers.cfm?abstract_id=1365907 [28.10.10].

DHARMAPALA, Dhammika, What Problems and Opportunities are Created by Tax Havens?, in Oxford Review of Economic Policy, v. 24, n 4, pp 661-679, 2008.

DILWORTH, H. Robert, International Tax Reform and Some Proposals to Consider, paper apresentado no Senate Finance Committee, "The Foundation of International Tax Reform: Worldwide, Territorial, and Something in Between", 2008.

DILWORTH, Robert H., Tax Reform: International Tax Issues and Some Proposals, in International Tax Journal, v. 35, $\mathrm{n}^{\circ}$ 1, 2009.

EASSON, Alex, Do we still need tax treaties?, in BIFD, v. 54, 2000, n 12, pp. 619-625. 
ENDE, Leo van den, HABERHAM, Amir, BOOGERT, Kees den, Tax expenditures in the Netherlands, in SWIFT, Zhicheng Li, BRIXI, Hana Polackova, VALENDUC, Christian (orgs.), Tax expenditures - shedding light on government spending through the tax system, Washington DC, The World Bank, 2004.

ENGLISH, Joachim, VAT/GST and direct taxes: different purposes, in LANG, Michael, MELZ, Peter, KRISTOFFERSSON, Eleonor (orgs.), Value added tax and direct taxation, Amsterdam, IBFD, 2009.

FALIS, Stefan, The aplicability of art. I and art. III of GATT to direct taxes, in HERDINWINTER, Judith, HOFBAUER, Ines (org.), The relevance of WTO law for tax matters, Wien, Linde, 2006.

FALZON, Franco, Most-favored-nation treatment in the GATS and its effect on direct taxation, in J. Herdin-Winter, I. Hofbauer, The relevance of WTO law for tax matters, Wien, Linde, 2006.

FOLTYN, Olga, The exemption method and fictitious tax credit as a prohibited subsidy under WTO law, in J. Herdin-Winter, I. Hofbauer, The relevance of WTO law for tax matters, Wien, Linde, 2006.

FREEDMAN, Judith, Treatment of capital gains and losses, in ESSERS, Peter e RIJKERS, Arie (eds.), The Notion of Income from Capital, Amsterdam, IBFD, 2005.

FRENKEL, Jacob, RAZIN, Assaf, SADKA, Efraim, Basic concepts of international taxation, Cambridge-MA, 1990, diponível [on line] in www.nber.org/papers/w3540 [28.07.06].

GALÁN, Paula, The meaning of "arbitrary and unjustifiable discrimination" and "disguised restriction”, in HERDIN-WINTER, Judith, HOFBAUER, Ines (org.), The relevance of WTO law for tax matters, Wien, Linde, 2006.

GAMMIE, Malcolm, The role of the European Court of Justice in the development of direct taxation in the European Union, in BIFD, v. 57, 2003, nº 03, pp. 86-98.

GENERAL AGREEMENT ON TARIFS AND TRADE, Declaration giving effect on the provisions of article XVI:4 of the General Agreements on Tarifs and Trade, 1960, disponível [on line] in http://www.wto.org/gatt_docs/English/SULPDF/91870122.pdf [29.01.2011].

GIFFITH, Thomas D., Theories of personal deductions in the income tax, 40 Hastings L.J. 343 (1989) (reproduzido em CARON, Paul L., BURKE, Karen C. e McCOUCH, 
Grayson M.P. Federal Income Tax Anthology. Cincinnati, Ohio, Anderson1997, $2^{\mathrm{a}}$ tiragem, 2003).

GRAU, Eros Roberto, A ordem econômica na constituição de 1988, 8 ed., São Paulo, Malheiros, 2003.

GREEN, Robert A., The interaction of tax and non-tax treaties, in BIFD, v. 56, 2002, $\mathrm{n}^{\circ} 6$, pp. 254-257.

GROSS, Jakob B., OECD defensive measures against harmful tax competition legality under WTO, in INTERTAX, v. 31, issue 11, 2003, pp. 390-400.

GRYNBERG, Roman, CHILALA, Bridget, WTO Compatibility of the OECD defensive measures' againt 'harmful tax competition', disponível [on line] in http://www.thecommonwealth.org/Shared_ASP_Files/UploadedFiles/C362653BC72C-4037-8D9B65FF4492A833 WTOCompatibilityoftheOECDDefensiveMeasuresagainstHarmfulT axCompetition.pdf [27.01.2011].

GUTTENTAG, Joseph H., Key issues and options in international taxation: taxation in an interdependent world, in BIFD, v. 55, 2001, $\mathrm{n}^{\circ}$ 11, pp. 546-556.

GUZMAN, Andrew T., Explaining the Popularity of Bilateral Investment Treaties, in Karl P. Sauvant, Lisa E. Sachs (orgs.), The Effects of Treaties on Foreign Direct Investment: Bilateral Investment Treaties, Double Taxation Treaties and Investment Flows, Oxford, Oxford University Press, 2009.

HAMMER, Richard M., GREEN, William H., The U.S. tax incentive for exports - to be or not to be, in BIFD, v. 55, 2001, no 9-10, pp. 513-522.

HENRIQUES, Elcio Fiori, O gasto tributário no direito brasileiro, 2009, disponível [online] http://www.tesouro.fazenda.gov.br/premio_TN/XIVPremio/financas/1tefpXIVPTN/ monografia_Tema2_Elcio_Fiori_Henriques.pdf [28.01.2011].

HILÚ NETO, Miguel, O elo jurídico entre a valoração aduaneira e os preços de transferência, in FERNANDES, Edison Carlos, Preços de transferência, São Paulo, Quartier Latin, 2007.

HINES JR., James R., Corporate taxation and international competition, Michigan, 2005, diponível [on line] in http://www.bus.umich.edu/otpr/wp2005-9.pdf [28.07.06]. 
HINES Jr., James R., SUMMERS, Lawrence H., How Globalization Affects Tax Design, Working Paper 14664, Cambridge, 2009, disponível [on line] in www.nber.org/papers/w14664 [30.07.09].

HINTSANEN, Lari, National report Finland, in LANG, Michael, HERDIN, Judith, HOFBAUER, Ines (org.), WTO and direct taxation, Kluwer Law, 2005.

HOLMES, Kevin, The concept of income - a multi-disciplinary analysis, Amsterdam, IBFD, 2001.

HONG, Lee Fook, Tax changes in China impending upon entry into the World Trade Organization, in BIFD, v. 56, 2002, $\mathrm{n}^{\circ} 11$, pp. 563-568.

HUCK, Hermes Marcelo, Evasão e elisão: rotas nacionais e internacionais do planejamento tributário, São Paulo, Saraiva, 1997.

HUGHES, David, Withholding taxes and the most favoured nation clause, in BIFD, v. 51, 1997, nº 3, pp. 126-130.

INFANTI, Anthony C., A tax crit identity crisis? Or tax expenditure analysis, deconstruction, and the rethinking of a collective identity, in Whittier Law Review, Vol. 26, (2005).

JANEBA, Eckhard, WILSON, John D., Tax competition and trade protection, CambridgeMA, disponíel [on-line] in www.nber.org/papers/w7402 [23.10.2005].

JOINT COMMETTEE OF TAXATION, A Reconsideration of Tax Expenditure Analysis (JCX-37-08), 2008, disponível [on-line] in http://www.jct.gov/x-37-08.pdf [30.07.09].

KAHN, Douglas A, LEHMAN, Jeffrey S., Tax expenditure budgets: a critical view, in 54 Tax Notes 1661 (1992) (reproduzido em CARON, Paul L., BURKE, Karen C. e McCOUCH, Grayson M.P. Federal Income Tax Anthology. Cincinnati, Ohio: Anderson1997. $2^{\text {a }}$ tiragem) 2003, pp. 310-312.

KELMAN, Mark G., Personal Deductions Revisited: Why They Fit Poorly in an 'Ideal' Income Tax and Why They Fit Worse in a Far from Ideal World, 31 Stan. L. Rev. 831 (1979) (reproduzido em CARON, Paul L., BURKE, Karen C. e McCOUCH, Grayson M.P. Federal Income Tax Anthology. Cincinnati, Ohio: Anderson1997. $2^{\mathrm{a}}$ tiragem, 2003). 
KORNHAUSER, Marjorie, The origins of capital gains taxation: what's law got to do with it?, in 39 Sw. L.J., 869 (1985) (reproduzido em CARON, Paul L., BURKE, Karen C. e McCOUCH, Grayson M.P. Federal Income Tax Anthology. Cincinnati, Ohio: Anderson1997. $2^{\mathrm{a}}$ tiragem), 2003.

LANG, Joachim, The Influence of tax principles on the taxation of income from capital, in ESSERS, Peter e RIJKERS, Arie (orgs.) The Notion of Income from Capital. Amsterdam: IBFD. 2005. pp. 3-31.

LEAGUE OF NATIONS ECONOMIC AND FINANCIAL COMMISSION, Report on Double Taxation: Document E.F.S.73.F.19, de 5 de abril de 1923.

LEJEUNE, Ine, DAOU-AZZI, Jeanine, POWELL, Mark, The balance has shifted to consumption taxes - lessons learned and Best practices for VAT, in LANG, Michael, MELZ, Peter, KRISTOFFERSSON, Eleonor (Orgs.), Value added tax and direct taxation: similarities and differences, Amsterdam, IBFD, 2009.

LEMGRUBER, Andréa, A tributação do capital: o imposto de renda da pessoa jurídica e o imposto sobre operações financeiras, in BIDERMAN, Ciro e ARVATE, Paulo (orgs.). Economia do Setor Público no Brasil, Rio de Janeiro, Elsevier, 2004.

LENJOSEK, Gordon J., A framework for evaluating tax measures and some methodological issues, in SWIFT, Zhicheng Li, BRIXI, Hana Polackova, VALENDUC, Christian (orgs.), Tax expenditures - shedding light on government spending through the tax system, Washington DC, The World Bank, 2004.

LENNARD, Michael, The GATT 1994 and direct taxes: some national treatment and related issues, in LANG, Michael, HERDIN, Judith, HOFBAUER, Ines (org.), WTO and direct taxation, Kluwer Law, 2005.

LI, Jinyan, Relationship between international trade law and national policy: case study of china, in BIFD, v. 59, 2005, n 2, pp. 77-86.

LINGGUANG, Bao, Economic globalization, WTO, and tax reform in China, in INTERTAX, v. 29, issue 10, 2001, p. 341-347.

LU, Lingbo, WTO-Compatibility of harmful tax practices, in HERDIN-WINTER, Judith, Ines Hofbauer, The relevance of WTO law for tax matters, Wien, Linde, 2006.

LUJA, Raymond H. C., Anti-tax-avoidance rules and fiscal trade incentives, in INTERTAX, v. 28, issue 6-7, 2000, pp. 226-240. 
McDANIEL, Paul R., The impact of trade agreements on tax systems, in INTERTAX, v. 30, issue 5, 2002, pp. 166-171.

McDANIEL, Paul R., Trade agreements and income taxation: interactions, conflicts, and resolutions, Boston, 2004, disponível [on line] in http://www.un.org/esa/ffd/aconf198-11.pdf [05.11.2005], também disponível [on line] in http://ssrn.com/abstract_id=499284 [23.10.2005].

McLURE Jr., Charles E., International Aspects of Tax Policy for the $21^{\text {st }}$ Century, American Journal of Tax Policy, v. 167, 1989-1990.

MERCADANTE, Aramita de Azevedo, Consolidação das normas do GATT 47, GATT 94 e OMC: legislação brasileira, São Paulo, Quartier Latin, 2007

MONROY, Antonio Grimaldo, The relevance of WTO Law for international tax Law, in J. Herdin-Winter, I. Hofbauer (org.), The relevance of WTO law for tax matters, Wien, Linde, 2006

MOTA, Pedro Infante, O princípio da não discriminação no sistema GATT/OMC, in Revista Fórum de Direito Tributário nº 24, 2006.

MUSGRAVE, Richard Abel, MUSGRAVE, Peggy B., Public finance in theory and practice, $4^{\mathrm{a}}$ ed., New York, McGraw-Hill, 1984.

NASSER, Rabih Ali, Política Industrial e os Acordos da OMC: Subsídios, TRIMs e Investimentos, São Paulo, 2003, disponível [on line] in http://www.direitogv.com.br/AppData/Publication/PoliticaIndustrialAcordosOMCRa bihNasser.pdf, [01.02.2011].

NOGUERA, Lionel, STEICHEN, Alain, National report Luxembourg, in LANG, Michael, HERDIN, Judith, HOFBAUER, Ines (org.), WTO and direct taxation, Kluwer Law, 2005.

NUSDEO, Fábio, Curso de economia: introdução ao direito econômico, $2^{\mathrm{a}}$ ed., São Paulo, RT, 2000.

OLIVEIRA, R. G. de, Análise de custo-benefício, in ARVATE, Paulo, BIDERMAN, Ciro (eds.), Economia do setor público no Brasil, Rio de Janeiro, Elsevier, 2004.

OLSEN, Monroe, GATS - National treatment and taxation, in HERDIN-WINTER, Judith, HOFBAUER, Ines (org.), The relevance of WTO law for tax matters, Wien, Linde, 2006. 
ORGANISATION FOR ECONOMIC CO-OPERATION AND DEVELOPMENT OECD, Harmful tax competition: an emerging global issue, 1998, disponível [on line] in www.oecd.org [23.10.2005].

ORGANISATION FOR ECONOMIC CO-OPERATION AND DEVELOPMENT OECD, Towards global tax co-operation: report to the 2000 ministerial council meeting and recommendations by the committee on fiscal affairs - progress in identifying and eliminating harmful tax practices, 2000, disponível [on line] in $\underline{\text { www.oecd.org [23.10.2005] }}$

PERSIANI, Alessio, Organizzazione Mondiale del Commercio, disciplina in material di sovvenzioni ed imposizione diretta: alcune riflessioni, in Diritto e pratica tributaria internazionale, $n$. 2, 2007, pp. 515-567.

PETRITZ, Michael, National report Austria, in LANG, Michael, HERDIN, Judith, HOFBAUER, Ines (org.), WTO and direct taxation, Kluwer Law, 2005.

RAZIN, Assaf, SADKA, Efraim, Capital income taxation in the globalized world, Cambridge-MA, 2004, diponível [on line] in www.nber.org/papers/w10630 [28.07.06].

RAZIN, Assaf, SADKA, Efraim, Capital market integration: issue of international taxation, Cambridge-MA, 1990, disponível [on line] in www.nber.org/papers/w3281 [28.07.06].

RAZIN, Assaf, SADKA, Efraim, YUEN, Chi-Wa, in Journal of International Economics 44 (1998) 45-68.

RAZIN, Assaf, SADKA, Efraim, YUEN, Chi-Wa, Tax principles and capital inflows: is it efficient to tax nonresident income?, Cambridge-MA, 1996, diponível [on line] in www.nber.org/papers/w5513 [28.07.06].

RAZIN, Assaf, YUEN, Chi-Wa, Understanding the "problem of economic development": the role of factor mobility and international taxation, Cambridge-MA, 1990, diponível [on line] in www.nber.org/papers/w7115 [28.07.06].

RECEITA FEDERAL DO BRASIL, Demonstrativo dos Gastos Governamentais Indiretos de Natureza Tributária - 2011 (Gastos Tributários), Brasília, 2011, disponível [on line] http://www.receita.fazenda.gov.br/publico/EstudoTributario/BensTributarios/2011/D GT2011.pdf [25.01.2011]. 
ROSEMBUJ, Tulio, Taxes and the World Trade Organization, in INTERTAX v. 35, issue 6/7, 2007.

RYBNIK, Daniel, Preços de transferência y entre partes independientes em la Argentina, in FERNANDES, Edison Carlos, Preços de transferência, São Paulo, Quartier Latin, 2007.

SAUVANT, Karl P., SACHS, Lisa E. The Effect of Treaties on Foreign Direct Investment Flows in Karl P. Sauvant, Lisa E. Sachs (orgs.), The Effects of Treaties on Foreign Direct Investment: Bilateral Investment Treaties, Double Taxation Treaties and Investment Flows, Oxford, Oxford University Press, 2009.

SCHÄFER, Anne, SPENGEL, Christoph, ICT and international corporate taxation: tax attributes and scope of taxation, Mannheim, 2002, diponível [on line] in ftp://ftp.zew.de/pub/zew-docs/dp/dp0281.pdf [28.07.06].

SCHÖN, Wolfgang, World Trade Organization Law and Tax Law, in BIFD v. 58, 2004, pp. 283-296.

SCHOUERI, Luís Eduardo, Aplicação concomitante da legislação de preços de transferência e da tributação do lucro em bases mundiais, in TORRES, Heleno Taveira (Org.), Direito Tributário Internacional Aplicado, $1^{\mathrm{a}}$ ed., São Paulo, Quartier Latin, 2005, v. 3, p. 239-254.

SCHOUERI, Luís Eduardo, Normas tributárias indutoras e intervenção econômica, Rio de Janeiro, Forense, 2005.

SCHOUERI, Luis Eduardo, Preços de transferência no direito tributário brasileiro, $2^{\mathrm{a}}$ Ed., São Paulo, Dialética, 2006.

SCHOUERI, Luis Eduardo, Princípios no Direito Tributário Internacional, Territorialidade, Fonte e Universalidade, in Roberto Ferraz (org.), Princípios e limites da tributação, São Paulo, Quartier Latin, 2005.

SCHOUERI, Luís Eduardo, Tratados e convenções internacionais sobre tributação, in RDTA nº 17, 2003, pp. 20-49.

SCHOUERI, Luís Eduardo, Tributação e cooperação internacional, in RFDT, $\mathrm{n}^{\circ}$ 07, 2004, pp. 25-54. 
SCHYLE, Michael, Most favoured nation treatment in tax matters in the GATT, in J. Herdin-Winter, I. Hofbauer (org.), The relevance of WTO law for tax matters, Wien, Linde, 2006, pp. 73-102.

SEGUIN, Marc, GURR, Simon, Federal tax expenditures in Canada, in SWIFT, Zhicheng Li, BRIXI, Hana Polackova, VALENDUC, Christian (orgs.), Tax expenditures shedding light on government spending through the tax system, Washington DC, The World Bank, 2004.

SHI, Yaobin, Establishing a tax expenditure administrative system that achieves a sound fiscal system in China, in SWIFT, Zhicheng Li, BRIXI, Hana Polackova, VALENDUC, Christian (orgs.), Tax expenditures - shedding light on government spending through the tax system, Washington DC, The World Bank, 2004.

SIMONS, Henry C., Personal income taxation, The University of Chicago Press, Chicago, 1938.

SINGH, Chandrajit, Non-Discrimination in Tax Matters in the GATT - National Treatment, in HERDIN-WINTER, Judith, HOFBAUER, Ines (org.), The relevance of WTO law for tax matters, Wien, Linde, 2006.

SLEMROD, Joel, Free Trade Taxation and Protectionist Taxation, NBER Working Paper Series, Working Paper $n^{\circ}$ 4902, National Bureau of Economic Research, Cambridge, October 1994, disponível [on line] in www.nber.org/papers/w4902 [23.10.2005].

STIGLITZ, Joseph E., Economics of the public sector, $3^{\mathrm{a}}$ ed., New York, Norton \& Company, 1999.

STOLER, Andrew L., The evolution of subsidies disciplines in GATT and the WTO, Sidney, 2009 diponível [on line] http://www.iit.adelaide.edu.au/conf/subsidies_usyd_0809.pdf.

SUNLEY, Emil, Tax expenditures in the United States: experience and practice, in SWIFT, Zhicheng Li, BRIXI, Hana Polackova, VALENDUC, Christian (orgs.), Tax expenditures - shedding light on government spending through the tax system, Washington DC, The World Bank, 2004.

SURREY, Stanley S., Federal income tax reform: the varied approaches necessary to replace tax expenditures with direct governmental assistance, in 84 Harvard Law Rev., 252 (1970) (reproduzido em CARON, Paul L., BURKE, Karen C. e McCOUCH, Grayson M.P. Federal Income Tax Anthology. Cincinnati, Ohio: Anderson 1997. $2^{a}$ tiragem) 2003, pp. 296-298. 
SURREY, Stanley S., McDANIEL, Paul R., The tax expenditure concept: current developments and emerging issues, in 20 B. C. L. Rev. (1979), (reproduzido em CARON, Paul L., BURKE, Karen C. e McCOUCH, Grayson M.P. Federal Income Tax Anthology. Cincinnati, Ohio: Anderson1997. $2^{\mathrm{a}}$ tiragem) 2003, pp. 299-302.

SWIFT, Zhicheng Li, BRIXI, Hana Polackova, VALENDUC, Christian, Tax expenditures: general concept, measurement, and overview of country practices, in SWIFT, Zhicheng Li, BRIXI, Hana Polackova, VALENDUC, Christian (orgs.), Tax expenditures - shedding light on government spending through the tax system, Washington DC, The World Bank, 2004.

TERRA, Ben J. M., WATTEL, Peter, J., European tax law, $4^{\mathrm{a}}$ ed., Deventer, Kluwer, 2005.

TERRA, Ben J. M., WATTEL, Peter, J., European tax law, $5^{\text {a }}$ ed., Alphen aan den Rijn, Kluwer, 2008.

THIEL, Servaas van, General report, in LANG, Michael, HERDIN, Judith, HOFBAUER, Ines (org.), WTO and direct taxation, Kluwer Law, 2005.

THORSTENSEN, Vera, OMC - Organização Mundial do Comércio: as regras do comercio internacional e a nova rodada de negociações multilaterais, $2^{\mathrm{a}}$ ed., São Paulo, Aduaneiras, 2001.

THURONYI, Victor, Comparative tax law, Kluwer, The Hague, 2003.

THURONYI, Victor, Tax expenditures: a reassessment, in 1988 Duke L. J. 1155, (reproduzido em CARON, Paul L., BURKE, Karen C. e McCOUCH, Grayson M.P. Federal Income Tax Anthology. Cincinnati, Ohio: Anderson1997. $2^{a}$ tiragem) 2003., pp. 306-309.

THURONYI, Victor, The Concept of Income, 46 Tax L. Rev. 45 (1990) ) (reproduzido em CARON, Paul L., BURKE, Karen C. e McCOUCH, Grayson M.P. Federal Income Tax Anthology. Cincinnati, Ohio: Anderson1997. 2a tiragem) 2003. pp. 107-111.

TURNIER, William J; Evaluating personal deductions in an income tax - the ideal, 66 Cornell L. Rev. 262 (1981) (reproduzido em CARON, Paul L., BURKE, Karen C. e McCOUCH, Grayson M.P. Federal Income Tax Anthology. Cincinnati, Ohio, Anderson 1997. $2^{\mathrm{a}}$ tiragem, 2003).

UNITED NATIONS - UN, Report on the panel discussion on international cooperation in tax matters held at the United Nations Headquarters, New York, on 22 October 2003, 
New York, 2003, disponível [on line] in http://www.un.org/esa/ffd/tax/1003CRP_on_tax.pdf [23.10.2005].

URETA, Santiago Solórzano, National report Mexico, in WTO and Direct Taxation, LANG, Michael, HERDIN, Judith, HOFBAUER, Inês (coord.) Kluwer Law International, 2005.

VALENDUC, Cristian, From tax expenditure reporting to tax policy analysis: some experience from Belgium, in SWIFT, Zhicheng Li, BRIXI, Hana Polackova, VALENDUC, Christian (orgs.), Tax expenditures - shedding light on government spending through the tax system, Washington DC, The World Bank, 2004.

VANDEVELDE, Kenneth J., A Brief History of International Investment Agreements, in Karl P. Sauvant, Lisa E. Sachs (orgs.), The Effects of Treaties on Foreign Direct Investment: Bilateral Investment Treaties, Double Taxation Treaties and Investment Flows, Oxford, Oxford University Press, 2009.

VASCONCELLOS, Roberto França de, Aspectos Econômicos dos Tratados Internacionais em Matéria Tributária in Revista de Direito Tributário Internacional 1, São Paulo, Quartier Latin, 2005, pp. 147-192.

VETTORI, Gustavo Gonçalves, MALHERBE, Jacques, Deducting Interest on Equity Capital: Brazilian and Belgian Tax Rules Compared, in Studi Tributari Europei v. 1, 2010.

VIMERCATE, Paolo de'Capitani di, VAT/GST and direct taxes: how can we distinguish them?, in LANG, Michael, MELZ, Peter, KRISTOFFERSSON, Eleonor (orgs.), Value added tax and direct taxation, Amsterdam, IBFD, 2009.

WHALLEY, John, Puzzles over international taxation of cross border flows of capital income, Cambridge-MA, 2001, disponível [on line] in www.nber.org/papers/w8662 [31.10.2005].

WORLD TRADE ORGANIZATION, GATT Analytical Index, disponível [on line] in http://www.wto.org/english/res_e/booksp_e/gatt_ai_e/gatt_ai_e.htm

ZHOU, Zibin, The definition of subsidies under the SCM agreement, in J. Herdin-Winter,

I. Hofbauer, The relevance of WTO law for tax matters, Wien, Linde, 2006. 